PAULO HENRIQUE OGATA

COMPÓSITOS FERRO-GRAFITA PARA COMPONENTES DE MOTORES COM PROPRIEDADES TRIBOLÓGICAS MELHORADAS 
PAULO HENRIQUE OGATA

\section{COMPÓSITOS FERRO-GRAFITA PARA COMPONENTES DE MOTORES COM PROPRIEDADES TRIBOLÓGICAS MELHORADAS}

Tese apresentada à Escola Politécnica da Universidade de São Paulo para a obtenção do título de Doutor em Engenharia

São Paulo 
PAULO HENRIQUE OGATA

\section{COMPÓSITOS FERRO-GRAFITA PARA COMPONENTES DE MOTORES COM PROPRIEDADES TRIBOLÓGICAS MELHORADAS}

Tese apresentada à Escola Politécnica da Universidade de São Paulo para a obtenção do título de Doutor em Engenharia

Área de concentração:

Engenharia Metalúrgica e de Materiais

Orientador: Prof. Titular Dr. Hélio Goldenstein

São Paulo 


\section{Este exemplar foi revisado e corrigido em relação à versão original, sob responsabilidade única do autor e com a anuência de seu orientador.}

São Paulo, 26 de janeiro de 2015.

Assinatura do autor

Assinatura do orientador

FICHA CATALOGRÁFICA

Ogata, Paulo Henrique

Compósitos ferro-grafita para componentes de motores com

propriedades tribológicas melhoradas / P.H. Ogata. -- versão corr. -- São Paulo, 2015.

$138 \mathrm{p}$.

Tese (Doutorado) - Escola Politécnica da Universidade de São Paulo. Departamento de Engenharia Metalúrgica e de Materiais.

1.Tratamento témico 2.Microscopia eletrônica de varredura 3.Microscopia ótica 4.Desgaste 5.Ferro fundido cinzento 6.Ferro fundido maleável I.Universidade de São Paulo. Escola Politécnica. Departamento de Engenharia Metalúrgica e de Materiais II.t. 
Dedico este trabalho a meus pais, minha namorada, professores e amigos 


\section{AGRADECIMENTOS}

Ao Prof. Dr. Hélio Goldenstein pela oportunidade concedida a mim, pela orientação, ensinamentos e conselhos despendidos no trabalho. Ao Prof. Amilton Sinatora pelos conselhos em relação aos testes de desgaste.

Aos meus amigos e colegas de pós-graduação.

Aos técnicos de laboratório do PMT Rafael, Veríssimo, Lívio, Rubens e Danilo pela ajuda nos experimentos deste trabalho.

À fundição TUPY pela doação das amostras.

FAPESP - Projeto FLEX

LTF - Laboratório de transformações de fase

LFS - Laboratório de fenômenos de superfície

À CAPES pela bolsa de doutorado 


\section{RESUMO}

A constante busca por motores com maior eficiência energética, requer a introdução de novos materiais ou inovações nas rotas de fabricação dos materiais existentes.

O presente trabalho busca, a partir de rotas de tratamento térmico, soluções para minimizar o desgaste originado no contato entre corpos metálicos em componentes submetidos a altas pressões de contato em regime lubrificado. A modificação microestrutural a partir de tratamentos térmicos originou matriz martensítica relativamente dura com uma dispersão refinada de nódulos esféricos de grafita, que atuariam como lubrificantes sólidos. O estudo baseou-se em dois ferros fundidos (cinzento e branco) submetidos a tratamentos de austenitização seguidos de tempera em óleo e revenimento em diferentes tempos. Ensaios de dilatometria foram efetuados nos dois materiais para estudar a cinética de grafitização secundaria sob diferentes condições de tratamento térmico. As propriedades mecânicas foram avaliadas por medidas de dureza Vickers das amostras tratadas termicamente.

Amostras de ferro fundido cinzento e de branco modificado por tratamentos térmicos foram ensaiadas em teste de desgaste por deslizamento, com intuito de avaliar a influência de modificações na superfície no coeficiente de atrito.

Palavras-chave: ferro fundido cinzento, ferro fundido branco, tratamento térmico, desgaste, coeficiente de atrito, cinética, microestrutura e grafita. 


\begin{abstract}
The constant search for engines with higher energy efficiency requires the development of new materials or manufacturing innovations on the routes of existing materials.

In the present work, heat treatment routs were investigated to minimize wear originated at the contact between metallic bodies into components subjected to high contact pressures in lubricated regime. Microstructural modification from heat treatments yielded relatively hard martensitic matrix with a fine dispersion of spherical graphite nodules, which act as solid lubricants. The study was based on two cast iron (gray and white) undergoing treatments of soaking (austenitizing) followed by quenching in oil and tempering at different times. Dilatometry tests were performed on both materials to study the kinetics of secondary graphitization under different heat treatment conditions. Mechanical properties were evaluated from Vickers hardness of the thermally treated samples.

Samples of gray cast iron and white modified by heat treatments were tested in sliding wear test, in order to assess the influence of changes in the surface friction coefficient.
\end{abstract}

Keywords: gray cast iron, white cast iron, heat treatment, wear, friction coefficient, kinetics, microstructure and graphite. 


\section{LISTA DE FIGURAS}

Figura 1 - Classificação da grafita segundo a norma ASTM A 247utilizando aumento de $100 \mathrm{X}$.

Figura 2- fluxograma mostrando a metodologia utilizada nas amostras de ferro fundido cinzento

Figura 3 - Fases do ferro fundido cinzento e suas respectivas frações para diferentes temperaturas, simuladas no software Thermo-Calc $®$. 30

Figura 4 - Ciclo térmico utilizado nas amostras de ferro fundido cinzento nos ensaios de dilatometria

Figura 5- Microestrutura do ferro fundido cinzento sem ataque, na condição como recebida.

Figura 6- Microestrutura do FCZ (a) e FCZ (b) atacadas com Nital 2\%, na condição como recebida.

Figura 7- Curva completa obtidas por dilatometria, compreendendo as etapas de austenitização, têmpera e revenido de um ferro fundido cinzento. 34 Figura 8 - Porcentagem de carbono de C na austenita em diferente temperaturas.

Figura 9- (a) curva de dilatometria obtidos durante a etapa de aquecimento e resfriamento a $900{ }^{\circ} \mathrm{C}$ de FCZ2, obtidos no dilatômetro Bähr. (b) início e fim da austenita. (c) início da transformação martensítica .36

Figura 10- Curva de dilatometria da amostra de ferro fundido cinzento. Caracterização microestrutural das regiões numerada no gráfico.

Figura 11- Curva de dilatometria da amostra de ferro fundido cinzento. Dados de dilatação do evento 2 .

Figura 12- Microestrutura do FCZ atacadas com Nital $2 \%$, austenitizada a $900{ }^{\circ} \mathrm{C}$ e resfriada rapidamente. 38

Figura 13- Microestrutura do FCZ2 atacadas com Nital $2 \%$, austenitizada a $900{ }^{\circ} \mathrm{C}$, temperada e revenida a $560{ }^{\circ} \mathrm{C}$ e resfriadas rapidamente. 38

Figura 14 - amostra de ferro fundido cinzento caracterizadas por (FEG). (a) amostra temperada; (b) amostra temperada e revenida. 39

Figura 15- Espectro de raios- $x$ de uma amostra de ferro fundido cinzento. (a) espectro 
da amostra temperada ; (b) temperada e revenida. $\alpha$ é martensita e y é austenita. .42 Figura 16 - Curva de revenimento da martensita [36].

Figura 17- Microestrutura do FCZ2 atacadas com Nital $2 \%$, austenitizada a $900{ }^{\circ} \mathrm{C}$, temperada e revenidas a $650{ }^{\circ} \mathrm{C}$ durante $5 \mathrm{~h}$.

Figura 18- Trecho correspondente ao tratamento isotérmico a $650{ }^{\circ} \mathrm{C}$ realizado no dilatômetro Bähr.

Figura 19 - Fração transformada de grafita aparente em função do tempo

Figura 20- Linearização dos dados de dilatometria de ferro fundido na isoterma a 650 ${ }^{\circ} \mathrm{C}$.

Figura 21 - Representação de um cubo, considerando a variação linear. .48

Figura 22 - nódulos/mm2 para diferentes condições de tratamentos térmicos [25]..51 Figura 23- Dureza das amostras austenitizadas a $900{ }^{\circ} \mathrm{C}$ por uma hora e revenidas a $650{ }^{\circ} \mathrm{C}$ em diferentes tempos.

Figura 24 - Diagrama ferro carbono com a temperatura do eutético estável e metaestável [13]. .55

Figura 25 - Curva de resfriamento para os ferros fundidos brancos e mesclados [13].

Figura 26 - Curva de maleabilização típica [44]

Figura 27 -Desenho esquemático demonstrando a nucleação de grafita na interface austenita/cementita eutética [2] .58

Figura 28- Efeito dos elementos Si e Mo na grafitização secundária. a) no tamanho da grafita secundária. b) na quantidade de grafita secundária [28].

Figura 29 - simulação das fases em equilíbrio em função da temperatura estimadas no software Thermo-Calc $₫$ de um ferro fundido branco.

Figura 30 - Ciclo térmico das amostras submetidas nos testes de dilatometria a partir de amostras de ferro fundido branco na condição bruta de solidificação.

Figura 31 - Microestrutura sem ataque da amostra na condição bruta de solidificação, mostrando a presença de nódulos de grafita.

Figura 32 - comparativo entre microestruturas obtidas por coquilhamento atacadas com Nital 2\%. (a) amostra de ferro branco com composição de ferro fundido cinzento; (b) amostra de um came coquilhado descrito na referência [40]. 66

Figura 33 - Ferro branco coquilhado com composição química de ferro cinzento. (a) 500 X; (b) 1000 X. Atacadas com Nital 2\%.

Figura 34 - Ferro branco tratado a $900{ }^{\circ} \mathrm{C}$ durante 3 min e revenido a $250{ }^{\circ} \mathrm{C}$ durante 
30 min. MEV usando elétrons secundários atacados com Nital $2 \%$.

Figura 35 - FBC 900-3. Crescimento de grafita a partir da cementita. ....................68

Figura 36 - Ataque profundo da matriz usando Nital 2\% (900-15) ..........................68

Figura 37 - MEV de amostras FBM. (a) 900-5; (b) 900-10; (c) 900-15; (d) 900-30...69

Figura 38 - Comparação de $V v$ e diâmetro médio de grafita para diferentes tempos de

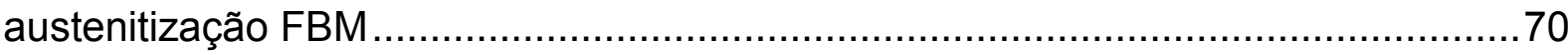

Figura 39 - Medida de dureza Vickers das amostras FBM. ……......................... 71

Figura 40 - Curva temperatura VS dilatação de amostras de ferro fundido branco na condição bruta de solidificação.

Figura 41 - Curva tempo vs dilatação da amostra 900-60

Figura 42 - curva de cinética das amostras de ferro branco ensaiadas no dilatômetro Bähr (a); .73

Figura 43 - Linearização dos primeiros $50 \%$ da transformação. .74

Figura 44 - Linearização entre 0,4 e 0,95 da transformação .75

Figura 45 - Curva total mostrando os dois trechos de linearização .75

Figura 46 - Determinação da energia de ativação em diferentes temperaturas de tratamento isotérmico $\left(850,900\right.$ e $\left.950^{\circ} \mathrm{C}\right)$. 76

Figura 47 - (a) contato conforme; (b) contato não-conforme. [20] …...................... 82

Figura 48 - Contato elástico entre dois corpos elípticos [51]. .83

Figura 49 - Contato esfera contra plano em um carregamento elástico [17].

Figura 50 - Tribossistema anel/lubrificante/cilindro. 85

Figura 51 - Curva de Stribeck para um rolamento lubrificado [20]. .86

Figura 52 - Curva de Stribeck (a) [12]; Regimes de lubrificação e desgaste no desgaste por deslizamento em regime lubrificado (b) Adaptado da referência [51] . 86 Figura 53 - Curva de Stribeck, adaptado da referência [56] .87

Figura 54 - Distribuição de pressão em regime elasto-hidrodinâmico (EHL) [51].....89 Figura 55 - Mudança do coeficiente de atrito e rugosidade em função do tempo ou distância de deslizamento em corpos sob condições de operação constante [58] ...90 Figura 56 - Fluxograma utilizado no trabalho.

Figura 57 - (a) anel e amostra fixados nos aparatos do OPTIMOL. (b) amostra posicionada na câmara de teste.

Figura 58 - Esquema mostrando a configuração contra-corpo (anel) e corpo (amostra) 96

Figura 59 - Caracterização do anel: (a) visão geral apresentando a camada nitretada 
(mais escura), (b) maior detalhe apresentando a espessura da camada nitretada (cerca de $17 \mu \mathrm{m}$ ).

Figura 60 - FBM submetido a tratamento a $900{ }^{\circ} \mathrm{C}$ durante 20 minutos, revenimento a $200{ }^{\circ} \mathrm{C}$ durante 30 minutos, atacados com Nital $2 \%$.

Figura 61 - Curva de atrito por deslizamento das amostras de FC em regime lubrificado.

Figura 62 - Curva de atrito por deslizamento das amostras de FBM em regime lubrificado.

Figura 63 - Curva de atrito por deslizamento (média de cinco medidas) das amostras de FC e FBM em regime lubrificado. 102

Figura 64 - marcas de desgaste no (a) anel (corpo); (b) contra-corpo (FC).........103 Figura 65 - marcas de desgaste no (a) anel (corpo); (b) contra-corpo (FBM). .......104 Figura 66 - Profundidades de desgaste lubrificado no FC obtidos no perfilômetro óptico. 105

Figura 67 - Profundidades de desgaste lubrificado no FB obtidos no perfilômetro óptico. 105

Figura 68 - Perfil de profundidades de desgaste lubrificado no FC obtidos no perfilômetro óptico (no sentido do movimento). 106

Figura 69 - Perfil de profundidades de desgaste lubrificado no FBM obtidos no perfilômetro óptico (no sentido do movimento). As escalas empregadas são diferentes.

Figura 70 - Marca de desgaste em 3D (lubrificado). (a) FC; (b) FB. 107

Figura 71 - MEV da amostra FC. (a) região ensaiada; (b), (c) região central; (d), (e), (f) região ponto morto. 108

Figura 72 - MEV da amostra FBM. (a) região não ensaiada; (b) região ensaiada; (c) região central; (d) região ponto morto. 109

Figura 73 - Curva de atrito por deslizamento de três testes realizados FC a seco. 110 Figura 74 - Curva de atrito por deslizamento de três testes realizados no FBM a seco.

Figura 75 - Curva de atrito por deslizamento das amostras de FC e FBM a seco. 110 Figura 76 - marcas de desgate a seco (a) contra-corpo (anel); (b) corpo de FC....112 Figura 77 - marcas de desgate a seco (a) contra-corpo (anel); (b) corpo de FBM. 113 Figura 78 - Profundidades de desgaste a seco no FC obtidos no perfilômetro óptico 
Figura 79 - Profundidades de desgaste no a seco FB obtidos no perfilômetro óptico 114

Figura 80 - Perfil de profundidades de desgaste a seco do FC obtidos no perfilômetro óptico (no sentido do movimento).

Figura 81 - Perfil de profundidades de desgaste a seco do FBM obtidos no perfilômetro óptico (no sentido do movimento. 115

Figura 82 - Volume aparente de desgaste (seco). (a) FC; (b) FB. 115

Figura 83 - MEV da amostra FC a seco. (a) ponto morto; (b), (c), (d) região central.

Figura 84 - Região de fim de curso submetido a ensaio de durabilidade usando dinamômetro [55].

Figura 85 - MEV da amostra FBM. (a) ponto morto; (b), (c), (d) região central. ..... 118

Figura 86 - Histograma da imagem analisada 134

Figura 87 - Histograma e lista com dados gerados 135

Figura 88 - calibração usando software Image J 136

Figura 89 - Seleção das grafitas e da área a ser quantificada usando o recurso Threshold 136

Figura 90 - quantificação das grafitas usando o comando analyse particle 137

Figura 91 - máscara da grafitas quantificadas 137

\section{LISTA DE TABELAS}

Tabela 1: Composição química do ferro fundido cinzento 29

Tabela 2 - Simulação em Thermo-Calc $®$ da composição química da austenita em equilíbrio a $900{ }^{\circ} \mathrm{C}$ de um ferro fundido cinzento. 35

Tabela 3 - Intensidades obtidas por amostras padrão para a austenita e martensita usando radiação de $\mathrm{Cu}$ [32] 40

Tabela 4 - Densidades calculadas usando o método de Arquimedes. 47 Tabela 5- Dureza HB para ferro fundido cinzento, austenitizado a $900^{\circ} \mathrm{C}$ e revenido a $650^{\circ} \mathrm{C}$ .52

Tabela 6 - Composição química do ferro fundido branco produzido na TUPY S.A...61 Tabela 7 - Simulação em Thermo-Calc $®$ da composição química da austenita em equilíbrio a $900^{\circ} \mathrm{C}$ de um ferro fundido branco. 
Tabela 8 - Identificação das amostras de ferro fundido branco .63

Tabela 9 - Ms obtidos a partir de ensaios dilatométricos usando o método da reta tangente e \%C na austenita determinado a partir da equação de Andrews. .72

Tabela 10 - Característica do rebolo .95

Tabela 11 - Resultados das medições de dureza do anel. 98 Tabela 12 - Rugosidade das superfícies antes dos ensaios de desgaste por deslizamento 100 


\section{LISTA DE ABREVIATURAS E SIGLAS}

ADI (Austempered ductile iron) - Ferro nodular austemperado

EHD - Regime elasto-hidrodinâmico

FBC - Ferro Branco Cinzento

FBM - Ferro Branco Modificado

FC - Ferro Cinzento

$\mathrm{Fe}_{3} \mathrm{C}$ - Carboneto de Ferro ou Cementita

HD - Hidrodinâmico

HV - Dureza Vickers

JMAK - Johnson-Mehl-Avrami-Kolmogorov

MEV - Microscopia Eletrônica de Varredura

MO - Microscopia Óptica

Ms (martensite start) - início da transformação martensítica

PAO (Polyalphaoleofin) - SpectraSyn TM 8

PEG - Primeiro Estágio de Grafitização

$\mathrm{RX}$ - raio $\mathrm{X}$

SEG - Segundo Estágio de Grafitização

$\mathrm{SiC}$ - carboneto de silício

TEE - Temperatura do eutético estável

TEM - Temperatura do eutético metaestável

UV - Ultra-violeta 


\section{LISTA DE SÍMBOLOS}

a - área de contato real

E - módulo elástico

G - Grafita

$h_{\min }$ - Espessura mínima do lubrificante

M - massa

P - Pressão

$\mathrm{R}$ - Raio

$\mathrm{R}_{\mathrm{q}}$ - Rugosidade quadrática média

$S_{a}$ - Média aritmética das alturas em módulo

$\mathrm{S}_{\mathrm{P}}$ - Maior altura de pico

SPC - Curvatura média dos picos

SPd - Densidade média de picos

SPK - Altura reduzida dos picos

$\mathrm{S}_{\mathrm{q}}$ - Altura média quadrática (RMS)

Svk - Altura reduzida de bacias

$U$ - Velocidade de deslizamento

$\mathrm{V}$ - volume

Vv - Fração Volumétrica

W - porcentagem em peso ou carga aplicada

$\alpha-$ Ferrita

$\mathrm{Y}$ - Austenita

$\rho$ - densidade

$\lambda$ - comprimento de onda ou espessura mínima do filme lubrificante e a rugosidade $v$ - Coeficiente de Poison 


\section{SUMÁRIO}

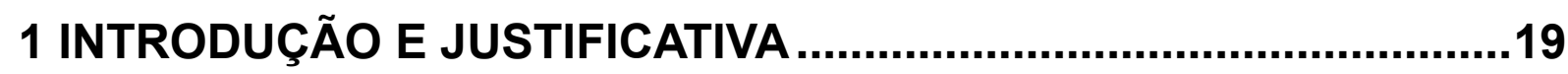

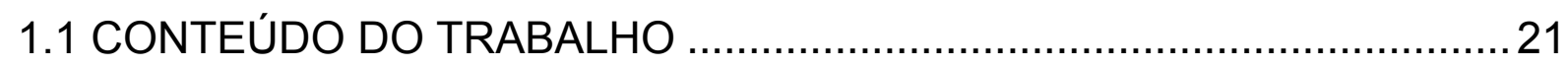

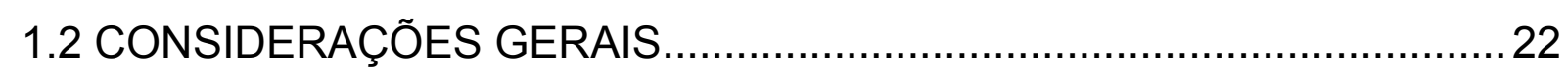

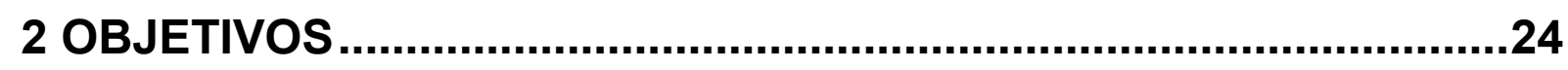

3 MODIFICAÇÕES NA MICROESTRUTURA DE UM FERRO FUNDIDO CINZENTO

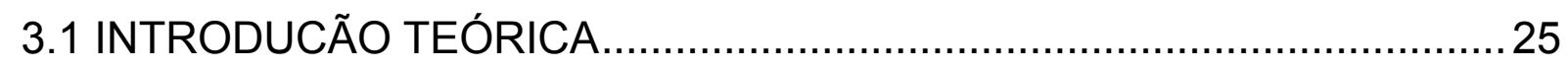

3.1.1 Ferro fundido cinzento........................................................................25

3.1.2 Grafitização secundaria (têmpera e revenimento)......................................26

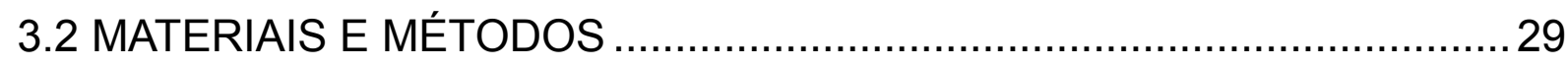

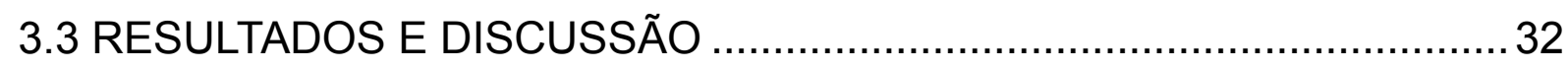

3.3.1 Caracterização microestrutural das amostras...........................................32

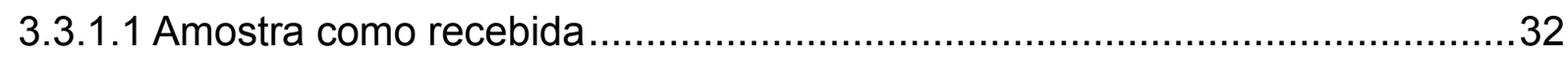

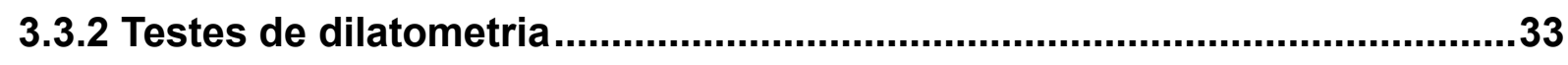

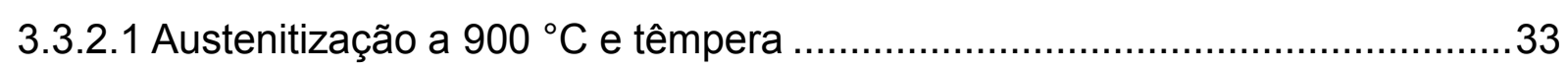

3.3.2.2 Etapa de austenitização ...................................................................... 33

3.3.3 Caracterização microestrutural das amostras obtidas por dilatometria ...36

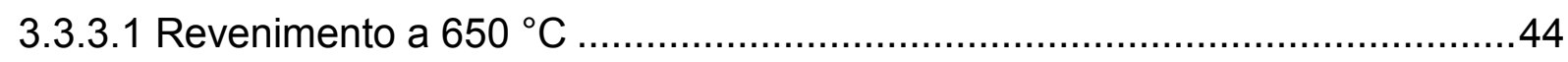

3.3.4 Densitometria pelo método de Arquimedes...............................................46

3.3.5 Tratamentos térmicos em banho de sal ...................................................50

3.3.5.1 Medidas de durezas vs tempo ............................................................

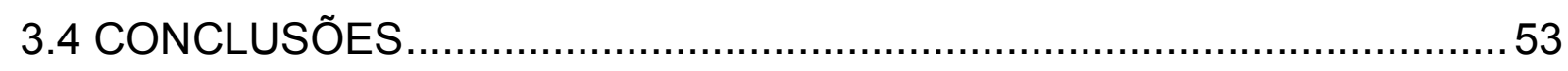

4 MODIFICAÇÕES MICROESTRUTURAIS EM UM FERRO FUNDIDO BRANCO COM DISPERSÕES FINAS DE GRAFITA ..........................54

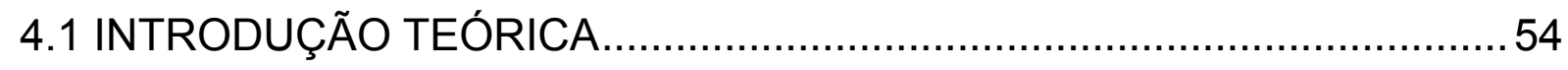

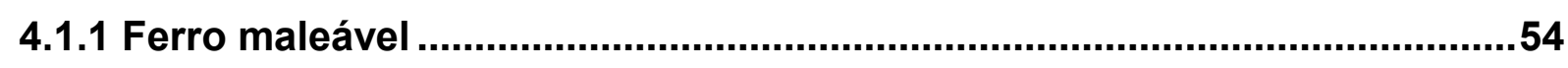

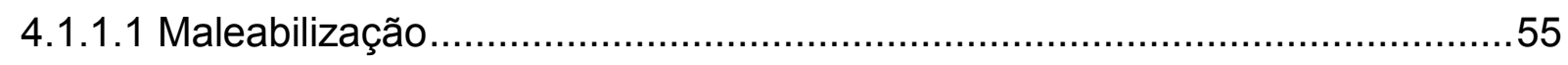

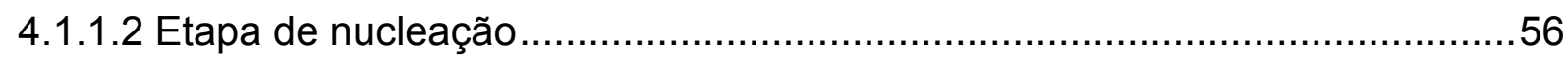

4.1.1.3 Cinética do primeiro estágio de grafitização ...............................................59 


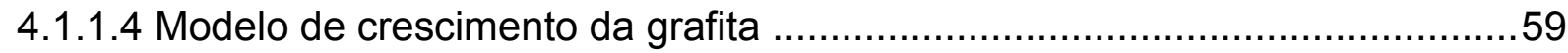

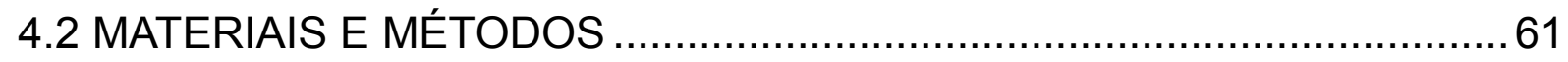

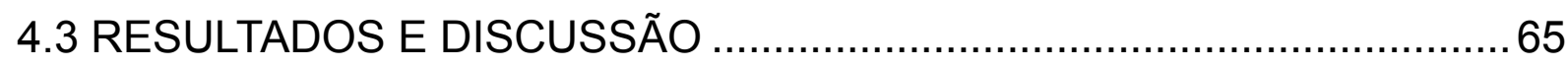

4.3.1 Caracterização microestrutural da amostra de ferro fundido branco na

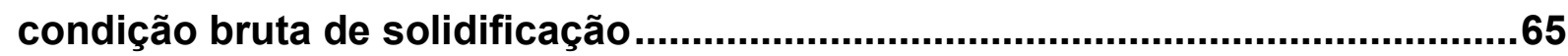

4.3.2 AMOSTRAS COMO RECEBIDAS SUBMETIDAS A TRATAMENTOS

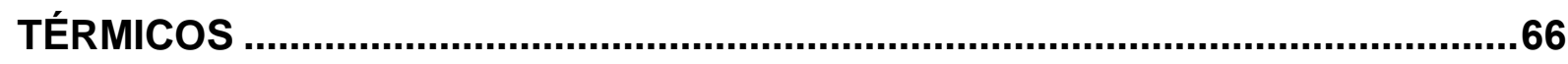

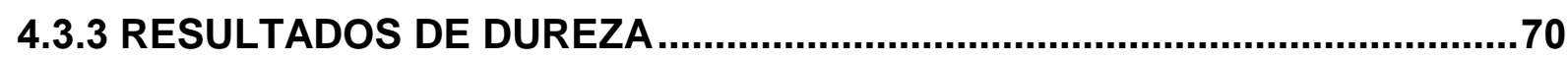

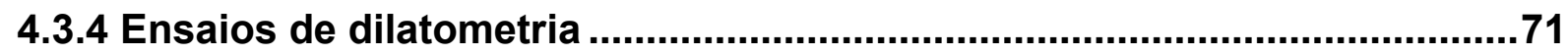

4.4 DISCUSSÃO DOS RESULTADOS APRESENTADOS ............................77

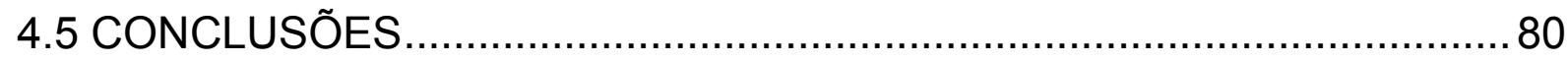

5 ENSAIOS DE DESGASTE POR DESLIZAMENTO ..........................81

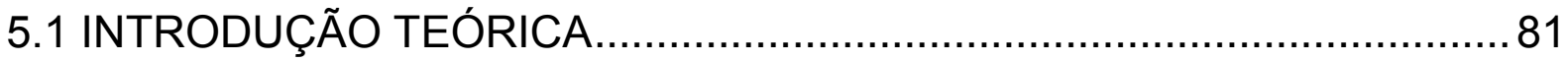

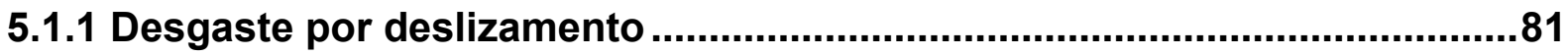

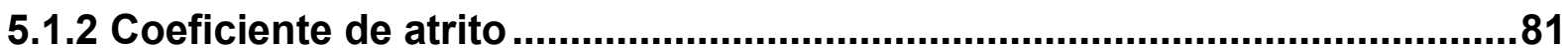

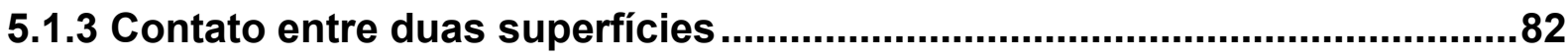

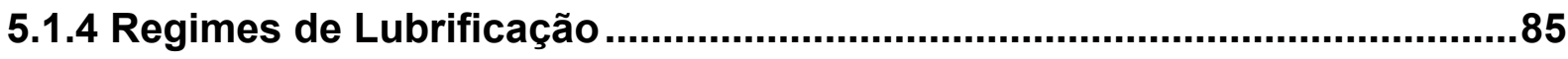

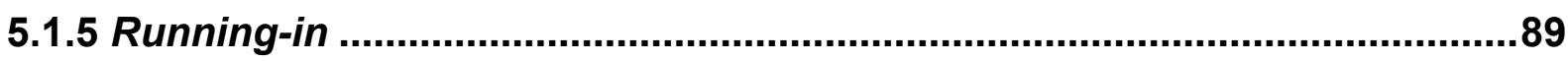

5.1.6 Relação entre microestrutura e tribologia ..................................................

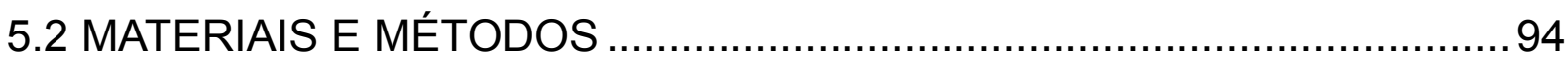

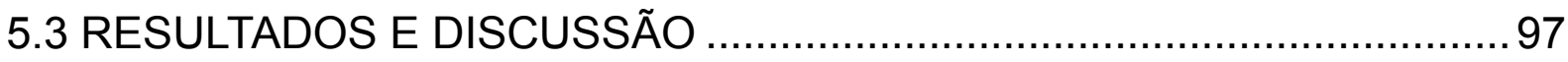

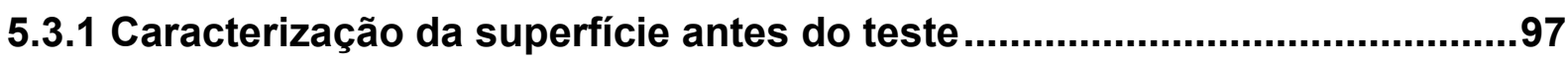

5.3.1.1 Caracterização do contra-corpo (anel) ….............................................97

5.3.1.2 Caracterização do corpo (camisa: FC e FBM) ………............................97

5.3.2 Medidas de rugosidade das superfícies: FC e FBM..................................99

5.3.3 Ensaio de desgaste: regime lubrificado..................................................100

5.3.3.1 Caracterização das superfícies de desgaste após o ensaio lubrificado por MO

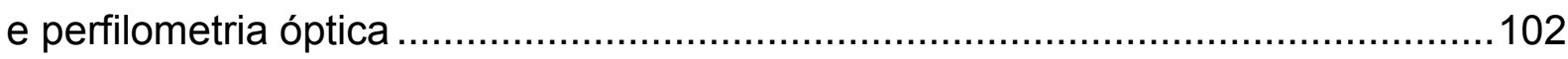

5.3.3.2 Caracterização por MEV das superfícies de desgaste após o ensaio..........107

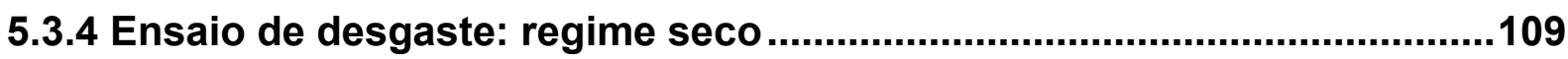

5.3.4.1 Caracterização das superfícies de desgaste após o ensaio a seco por MO e

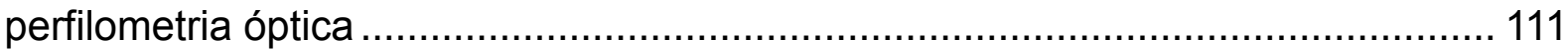

5.3.4.2 Caracterização por MEV das superfícies de desgaste após o ensaio..........116 
5.3.5 Discussão dos resultados apresentados..................................................118

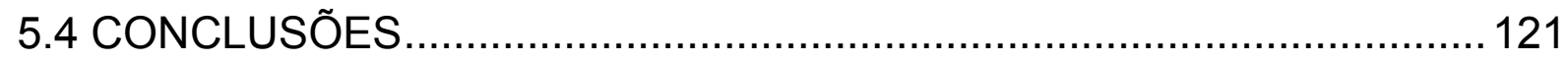

6 CONCLUSÃO GERAL ...............................................................122

7 SUGESTÕES PARA TRABALHOS FUTUROS ..............................123

REFERÊNCIAS ...........................................................................124

APÊNDICE A - ESPECIFICAÇÃO DO ÓLEO PAO.............................129

ANEXO A - DETERMINAÇÃO DA FRAÇÃO DE AUSTENITA............131

ANEXO B - DETERMINAÇÃO DO TEOR DE CARBONO .................133

ANEXO C - DETERMINAÇÃO DA FRAÇÃO VOLUMÉTRICA DE GRAFITA....................................................................................134

ANEXO D - DETERMINAÇÃO DO DIÂMETRO DOS NÓDULOS DE

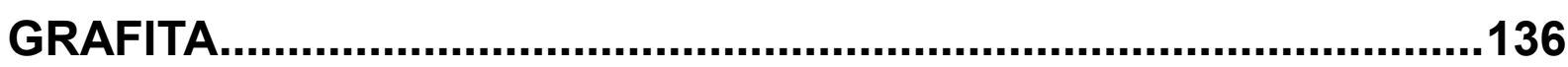




\section{INTRODUÇÃO E JUSTIFICATIVA}

O incentivo do governo em reduzir o imposto sobre produtos industrializados para veículos com maior autonomia de combustível proporciona a busca de alternativas para aumentar a eficiência dos motores nos automóveis atuais.

A eficiência dos motores automotivos em transferir a energia originada na queima de combustível em energia transmitida para movimentar o carro é muito baixa. De acordo com estimativas baseadas em estudos em veículos de passageiros, um terço da energia obtida pela queima de combustível é usada para superar o atrito do motor, transmissão pneus e freios, ao passo que somente $21,5 \%$ da energia total é transmitida para as rodas [1].

Em meio a esse contexto, reduzir as perdas por atrito, de modo a melhorar a eficiência do motor, tornou-se necessário. Por sua vez, o desgaste e o atrito originado entre corpos em contato podem ser minimizados de diferentes formas:

- É possível promover modificações microestruturais na superfície de contato, endurecendo ou modificando a natureza das fases que participam do contato metal/metal.

- É possível adicionar fontes de lubrificantes sólidos, através da incorporação de uma fase com natureza lubrificante dispersa no material.

- É possível ainda modificar a topografia das superfícies de contato de forma a melhorar a lubrificação, criando reservatórios naturais de óleo lubrificante.

Até recentemente, estruturas ferro-grafita esferoidais eram industrialmente obtidas também por decomposição do eutético ledeburítico no estado sólido [2], produzindo o ferro fundido maleável; este fenômeno é conhecido como grafitização secundária.

Em ferros fundidos nodulares a grafitização secundária é muitas vezes identificada como um defeito ocasionado por tratamentos térmicos: é a precipitação de grafita finamente dispersa em ferros fundidos temperados, quando revenidos em alta temperatura. Porém, em algumas circunstâncias os efeitos da morfologia desta grafita podem ser benéficos a algumas propriedades mecânicas [3]. Mais recentemente uma série de aços contendo dispersões de grafita obtidas por precipitação no estado sólido tem sido descritos na literatura [4-7]. A nucleação da 
grafita no estado sólido em aços foi estudada em detalhes por Edmonds [8].

A presença de grafita promove a redução de atrito em ferros fundidos ADI não ligado, reduzindo o atrito em superfícies lubrificadas e mesmo na ausência temporária de lubrificação [9]. A visão moderna é que para promover a grafitização é preciso ter uma composição que permita o predomínio termodinâmico da grafita sobre a cementita, através de adições de Si ou alternativamente Al, mas também é preciso que haja fases nucleantes da grafita, que são em geral nitretos. Outro possível benefício da grafitização seria a utilização dos vazios deixados pela grafita durante a ação do contato entre os corpos, como micro-reservatórios de lubrificante. Existe outra rota desenvolvida na UFSC, onde a partir de metalurgia do pó + SiC, origina um material sinterizado com propriedades autolubrificantes [10].

A ideia de se estudar a influência da formação de grafita secundária vem de trabalhos anteriores realizados pelo grupo de pesquisa. Vatavuk et al. [3] realizaram a têmpera e revenimento $\left(690^{\circ} \mathrm{C}\right.$ durante 5 horas) de um ferro fundido nodular, observando a formação de grafita secundária; outro trabalho interessante foi o apresentado por Lima e Goldenstein [11], no qual é reportado que a refusão a laser em ferro fundido resultou em ferro branco com uma microestrutura refinada de ledeburita, também sendo observada a precipitação de grafita onde os passes do feixe de laser se sobrepunham.

A proposta deste projeto é a obtenção de uma dispersão micrométrica (eventualmente nanométrica) de grafita secundária, seja a partir de um ferro fundido cinzento ou de um ferro fundido branco. A grafita secundária formada serviria como lubrificante sólido entre as partes móveis (por exemplo, entre a camisa e os anéis de um par cilindro pistão, ou a superfície do came e seguidor).

As rotas a serem exploradas são variações das rotas convencionais, de forma a não aumentar excessivamente o custo de fabricação dos componentes, com modificações dos processos e dos materiais de forma a permitir a precipitação in situ de grafita secundária. Uma rota escolhida foi a de produzir uma estrutura ledeburítica extremamente refinada, por coquilhamento, e submetê-la à maleabilização. A outra rota explorada foi a de precipitação de grafita diretamente a partir de uma solução sólida supersaturada de carbono, obtida pela têmpera a partir de alta temperatura. 


\subsection{CONTEÚDO DO TRABALHO}

O presente trabalho foi dividido em capítulos, os capítulos 3 e 4 abordam diferentes materiais submetidos a tratamentos térmicos e no capítulo 5 o ensaio de desgaste por deslizamento feito no material apresentado no capítulo 4 .

O capítulo 3 aborda os resultados obtidos nos tratamentos térmicos efetuados em ferros fundidos cinzentos, material utilizado em blocos de motores automotivos de combustão interna. A partir do ferro fundido cinzento com alto teor de silício, tratamentos térmicos de têmpera e revenimento foram efetuados para propiciar a formação de nódulos de grafita secundária. Corpos de prova deste material foram submetidos a ensaios de dilatometria para a determinação da cinética de grafitização.

No capítulo 4 são apresentados os resultados obtidos a partir do tratamento de maleabilização do material coquilhado com composição química de um ferro fundido cinzento comercial. Esta rota visa à dissolução parcial da cementita em prol da formação de uma grande quantidade de finos nódulos de grafita dispersos em uma matriz de martensita revenida. O objetivo deste tratamento é reduzir o coeficiente de atrito e o desgaste dos corpos em contato, originada pela matriz dura (martensita revenida) e pelo efeito de lubrificação em estado sólido decorrente dispersão de grafita.

No capítulo 5 são apresentados os resultados de desgaste do ferro fundido cinzento e do ferro branco com composição química de ferro cinzento modificado por tratamentos térmicos.

No capítulo 6 são apresentados a conclusão geral do trabalho. 


\subsection{CONSIDERAÇÕES GERAIS}

Os ferros fundidos são empregados em aplicações que envolvem desgaste de motores automotivos. Geralmente, os ferros fundidos utilizados em aplicações que requerem alto desempenho necessitam de adições de elementos de liga como: Si, Mo $\mathrm{Cu}, \mathrm{Sn}, \mathrm{Cr}$ e Mn. A adição destes elementos químicos na composição química modifica a cinética de transformação entre as fases envolvidas, e, consequentemente, a microestrutura resultante, otimizando as propriedades mecânicas relevantes às atividades que o material irá desempenhar.

A microestrutura característica dos ferros fundidos é formada basicamente por matriz (ferrita, perlita, bainita ou martensita) acompanhada por partículas ou esqueletos de grafita, carbonetos e pequenas quantidades de inclusões e outras fases (dependentes dos elementos de liga).

A grafita presente na matriz muitas vezes é associada a perdas nas propriedades mecânicas. Devido a seu caráter frágil, pode ser considerada uma descontinuidade na matriz e um concentrador de tensões. Por consequência, a partir desta fase podem originar trincas no material e torná-lo susceptível a falhas. Assim, a morfologia da grafita é um item importante a ser avaliado: quanto mais esférica, menor o acúmulo de tensões. Em contrapartida, em muitas aplicações a presença de grafita traz benefícios à atividade desempenhada. Como exemplo, a grafita lamelar dos ferros fundidos cinzentos ajuda no amortecimento das vibrações de um motor em funcionamento, além de ser um ótimo dissipador de calor [12].

Originalmente, a família de ferros fundidos foi classificada pela característica da fratura do material ou associada a uma propriedade mecânica. Com a utilização de metalografia, surgiram classificações baseadas na microestrutura, como pela morfologia da grafita e da matriz metálica. Neste contexto, a classificação moderna consiste de mistura entre a classificação microestrutural e à feita em relação às propriedades mecânicas. Assim, os ferros fundidos são classificados como: cinzento, branco, vermicular, nodular, mesclado e maleável [12,13].

A modificação da microestrutura da superfície com o intuito de melhorar as propriedades tribológicas do material, pode ser obtida via tratamento térmico ou "engenheirando" a superfície, como por exemplo a introdução de microcavidades com técnicas de polimento [14] ou com laser $[15,16]$ ou criando filmes de carbono a laser [17] ou técnicas de aspersão térmica por plasma em cilindro [18] ou através de 
técnicas de usinagem como o brunimento [19]. Materiais assim obtidos encontram aplicações em uma grande gama de produtos, como rolamentos, comando de válvulas, camisa/anel do pistão, etc. Associado ao endurecimento da matriz via tratamentos térmicos, lubrificantes sólidos podem ser introduzidos na matriz com o intuito de reduzir o atrito e desgaste da superfície em deslizamento. Existem lubrificantes sólidos muitos conhecidos como: bissulfeto de molibdênio, nitreto de boro hexagonal, ácido bórico, grafita, metais moles, alguns polímeros, óxidos, etc [20]. Os lubrificantes sólidos atuam quando o lubrificante presente entre as superfícies é insuficiente para impedir o contato entre as duas superfícies. Neste trabalho o lubrificante sólido escolhido é a grafita. 


\section{OBJETIVOS}

Este trabalho tem por objetivo estudar rotas de processamento que produzam estruturas com uma dispersão fina (micro ou nanométrica) de partículas de grafita com potenciais aplicações tribológicas. O estudo foi conduzido em duas frentes:

A primeira se concentra na precipitação de grafita secundária em um ferro fundido cinzento com alta concentração de silício. A obtenção de uma fina dispersão de nódulos de grafita na matriz de um ferro fundido cinzento poderia, por exemplo, ser uma forma de diminuir o atrito entre camisa e anel em motores à explosão.

A segunda frente aborda um tratamento de maleabilização, partindo de amostras coquilhadas de composição química de um ferro fundido cinzento comercial. O propósito desta rota é a obtenção de um material de matriz relativamente dura com uma dispersão fina de grafita secundária.

O material do bloco (ferro fundido cinzento) e o ferro branco modificado foram avaliados em testes de desgaste por deslizamento em regime lubrificado e a seco para a verificação da influência da modificação da superfície no coeficiente de atrito. 


\section{MODIFICAÇÕES NA MICROESTRUTURA DE UM FERRO FUNDIDO CINZENTO}

\subsection{INTRODUCÃO TEÓRICA}

\subsubsection{Ferro fundido cinzento}

O ferro fundido cinzento é um dos materiais de engenharia mais antigos existentes e atualmente continua sendo utilizado em diversas aplicações, uma vez que apresenta várias características não encontradas em outros materiais, além de possuir baixo custo produção.

As principais características do ferro fundido cinzento são sua elevada condutividade térmica, notável capacidade de amortecimento de vibrações e excelente usinabilidade. É um dos materiais de menor intervalo de fusão entre as ligas ferrosas e, além disso, a contração decorrente da passagem do estado líquido para o sólido é baixa, favorecendo a obtenção de peças sem defeitos internos. Assim, para a maioria das aplicações pode ser utilizado no estado bruto de solidificação [12,21]. Em razão destes atributos, os ferros fundidos cinzentos são empregados em tambores, cabeçotes de motor e disco de freios (componentes sujeitos a fadiga térmica), como também em bloco de motor, carcaças e discos de freio (componentes sujeitos a vibrações e restrições de ruídos).

A microestrutura de um ferro fundido cinzento é composta por matriz ferrítica ou perlítica (convencional) e veios de grafita (esqueleto contínuo de célula eutética). A grafita nos ferros fundidos cinzentos apresenta morfologia em forma de veios, que proporciona um grande acúmulo de tensões.

A norma ASTM A247 [22] classifica a grafita nos ferros fundidos cinzentos em cinco diferentes tipos (A, B, C, D e E), representados na Figura 1.

Os ferros fundidos cinzentos são especificados segundo as propriedades mecânicas de tração, sendo indicados normalmente os limites mínimos de resistência. A faixa de limite de resistência dos ferros fundidos cinzentos está entre 100 a 400 MPa. A norma ASTM A48 [23] classifica esse material de forma simples e clara, fornecendo a resistência em tração em ksi [12]. 

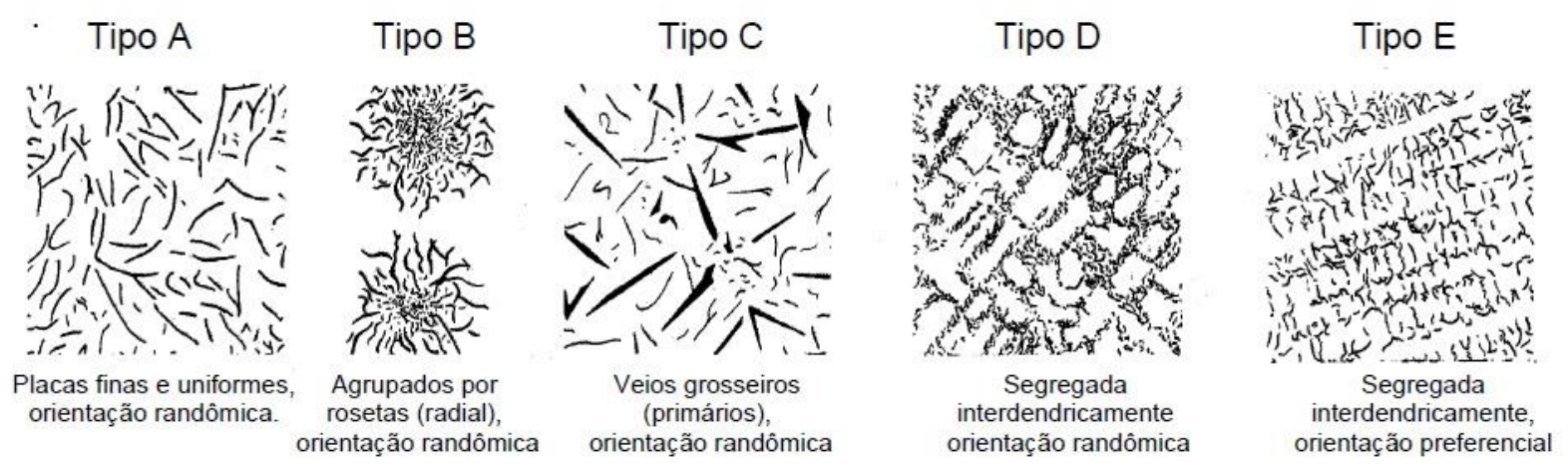

Figura 1 - Classificação da grafita segundo a norma ASTM A 247utilizando aumento de $100 \mathrm{X}$.

\subsubsection{Grafitização secundaria (têmpera e revenimento)}

"Grafita secundaria" é o nome dado tradicionalmente à precipitação no estado sólido de grafita a partir de soluções sólidas supersaturadas em carbono, quando submetidos a tratamentos térmicos em temperaturas abaixo da temperatura eutetóide. Geralmente é considerada um defeito de tratamento térmico, por diminuir o alongamento do material [12]. No final dos anos 80 este fenômeno foi estudado como forma de tenacificar ferros fundidos nodulares ferríticos submetidos a impacto em baixas temperaturas. Vatavuk et al. [3] observaram a diminuição da temperatura de transição dúctil/frágil na presença de fina e abundante distribuição de nódulos na escala micrométrica de grafita nestes materiais [3].

Neste capítulo, discute-se o princípio de se utilizar este fenômeno como uma rota para obter uma fina distribuição de partículas autolubrificantes que podem auxiliar o desempenho tribológico de componentes submetidos a solicitações do tipo metal/metal lubrificado. Esta ideia surgiu de discussões em que participaram o autor deste trabalho, o prof. Hélio Goldenstein e o prof. Wilson Guesser. Como consequência desta discussão surgiram o mestrado de Amanda Pimentel na UDESC e o presente trabalho $[24,25]$.

No processo proposto, o ferro fundido é aquecido até o campo austenita + grafita e resfriado com altas taxas de resfriamento, geralmente utilizando óleo para evitar possíveis trincas. O rápido resfriamento proporciona a transformação instantânea da fase austenita em martensita, devendo ainda conter austenita retida após a têmpera. Subsequentemente, o tratamento térmico de revenimento atua na nucleação de grafita secundária a partir do revenimento da martensita supersaturada 
em carbono.

A nucleação de grafita secundária pode ser influenciada por diferentes fatores como: temperatura e tempo de austenitização; presença de defeitos microestruturais.

A temperatura de austenitização e o tempo de tratamento afetam a concentração de carbono na austenita, fato que influencia a morfologia da microestrutura e a dureza da martensita pós têmpera. Askeland [26] estudou os efeitos da temperatura de austenitização, dureza e microestruturas em tratamentos de têmpera e revenimento em ferros fundidos nodulares austenitizados (por duas horas), temperados e revenidos a $677^{\circ} \mathrm{C}$ (também durante duas horas). Os tratamentos de austenização efetuados em amostras de ferro fundido nodular em temperaturas inferiores a $816^{\circ} \mathrm{C}$ não formaram grafita secundária. Askeland determinou ainda que para que haja nucleação de grafita secundária, a concentração de carbono na martensita precisa ser de no mínimo 0,35\% em peso [26].

Outro parâmetro importante a ser controlado para que ocorra a grafitização secundária é o tempo do tratamento de revenimento. Em tempos curtos de tratamentos de revenimento, o número de nódulos de grafita secundária por unidade de área resultante é muito pequeno; provavelmente porque a difusão de carbono na matriz martensítica se limita ao enriquecimento dos carbonetos formados durante a austenitização e, em menor quantidade, na formação de grafita secundária. O tempo de tratamento de austenitização influencia na quantidade de carbono solubilizado na austenita (martensita pós têmpera) e consequentemente na quantidade e morfologia da grafita secundária (após tratamento de revenimento) [26].

Askeland também observou que sítios de nucleação de grafita secundária foram formados na intersecção das placas de martensita e defeitos microestruturais. Em altas temperaturas de austenitização as ripas de martensita apresentam-se grosseiras, diminuindo a área de intersecção entre placas, reduzindo os sítios de nucleação de grafita secundária [26].

Burke [27] estudou a grafitização secundária em ferros fundidos nodulares, descrita como precipitação do excesso de carbono em solução na austenita durante o resfriamento. Por outro lado, a formação de grafita secundaria poderia ocorrer a partir da decomposição de matrizes perlíticas, bainíticas ou martensíticas, em grafita secundária e ferrita, por tratamento de recozimento abaixo da temperatura eutetóide estável. Burke acrescenta que a grafitização secundária da perlita e da austenita se dá pelo crescimento dos nódulos primários de grafita (deposição do carbono sobre 
partículas pré-existentes), enquanto que a decomposição da martensita seria um fenômeno comum ao aço, ocorrido após têmpera e revenido ou em tratamentos de normalização [28]. Neste caso, a grafita se apresentaria distribuída aleatoriamente em uma matriz de ferrita (ou martensita revenida).

Alguns autores [29] citam que a formação de grafita secundária pode ocorrer mais rapidamente durante o tratamento de recozimento, sendo esta originada pela evolução da cementita (precipitada no revenimento) em grafita secundária. Em aços, a formação de grafita secundária geralmente ocorre após longos períodos de tratamentos térmicos, em temperaturas acima de $600{ }^{\circ} \mathrm{C}$. 


\subsection{MATERIAIS E MÉTODOS}

A composição química do ferro fundido cinzento, fornecidos pela TUPY S.A utilizados neste trabalho pode ser acompanhado na Tabela 1.

Tabela 1: Composição química do ferro fundido cinzento

\begin{tabular}{|c|c|c|c|c|c|c|}
\hline $\mathrm{C}$ & $\mathrm{Si}$ & $\mathrm{Mn}$ & $\mathrm{P}$ & $\mathrm{S}$ & $\mathrm{Cr}$ & $\mathrm{Cu}$ \\
\hline 3,15 & 2,8 & 0,4 & $<0,04$ & 0,1 & $<0,03$ & 0,5 \\
\hline
\end{tabular}

A metodologia utilizada no trabalho pode ser acompanhada na Figura 2. A primeira etapa consistiu em caracterizar a amostra na condição como recebida. As superfícies foram preparadas usando técnicas metalográficas convencionais e foram devidamente caracterizadas por microscopia óptica (MO) e eletrônica por varredura (MEV). Posteriormente, as propriedades mecânicas foram avaliadas por medidas de durezas. A seguir, objetivando encontrar a temperatura de austenitização adequada ao material em estudo, foi feito uma simulação do mapeamento das fases em equilíbrio para diferentes temperaturas no software Thermo-Calc®, utilizando o banco de dados TCFE e a composição química do ferro fundido em estudo.

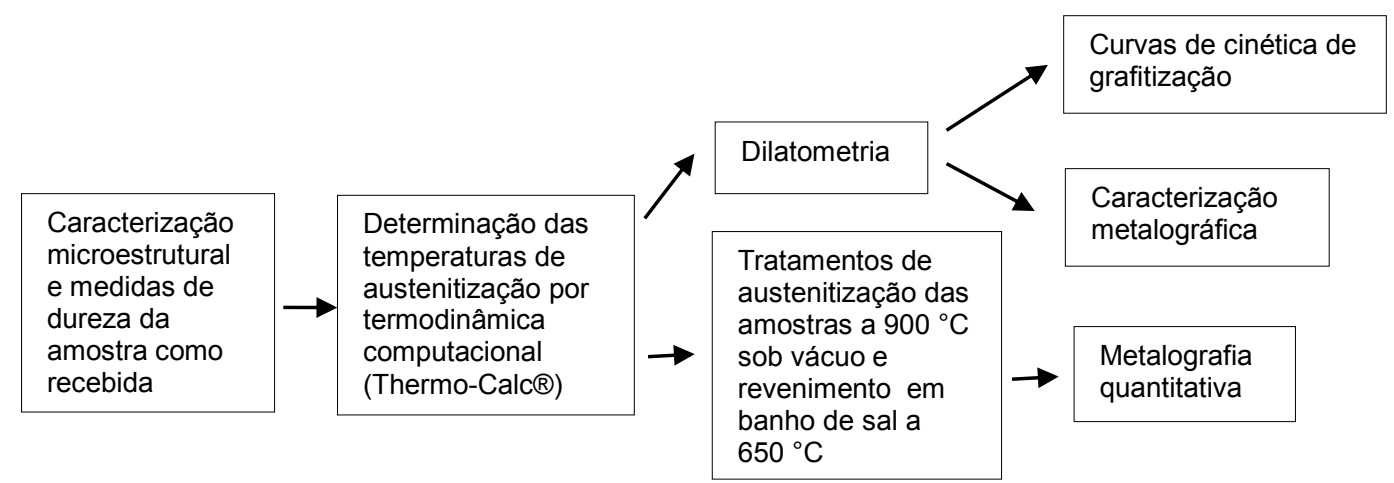

Figura 2- fluxograma mostrando a metodologia utilizada nas amostras de ferro fundido cinzento

A partir da Figura 3, nota-se que para a temperatura de $900{ }^{\circ} \mathrm{C}$ as fases em equilíbrio são austenita e grafita. A escolha de temperaturas relativamente baixas seguiu o raciocínio proposto por Askeland [26], que apontou que baixas temperaturas de austenitização dão origem a placas finas de martensita que favorecem a formação de núcleos de grafita secundária. O autor ainda afirmou que o fator mais significativo na formação de grafita secundária está relacionado à maior área de interface das ripas de martensita. No entanto, temperaturas muito inferiores levariam ao demasiado empobrecimento da austenita em carbono, impedindo a reação de grafitização. 


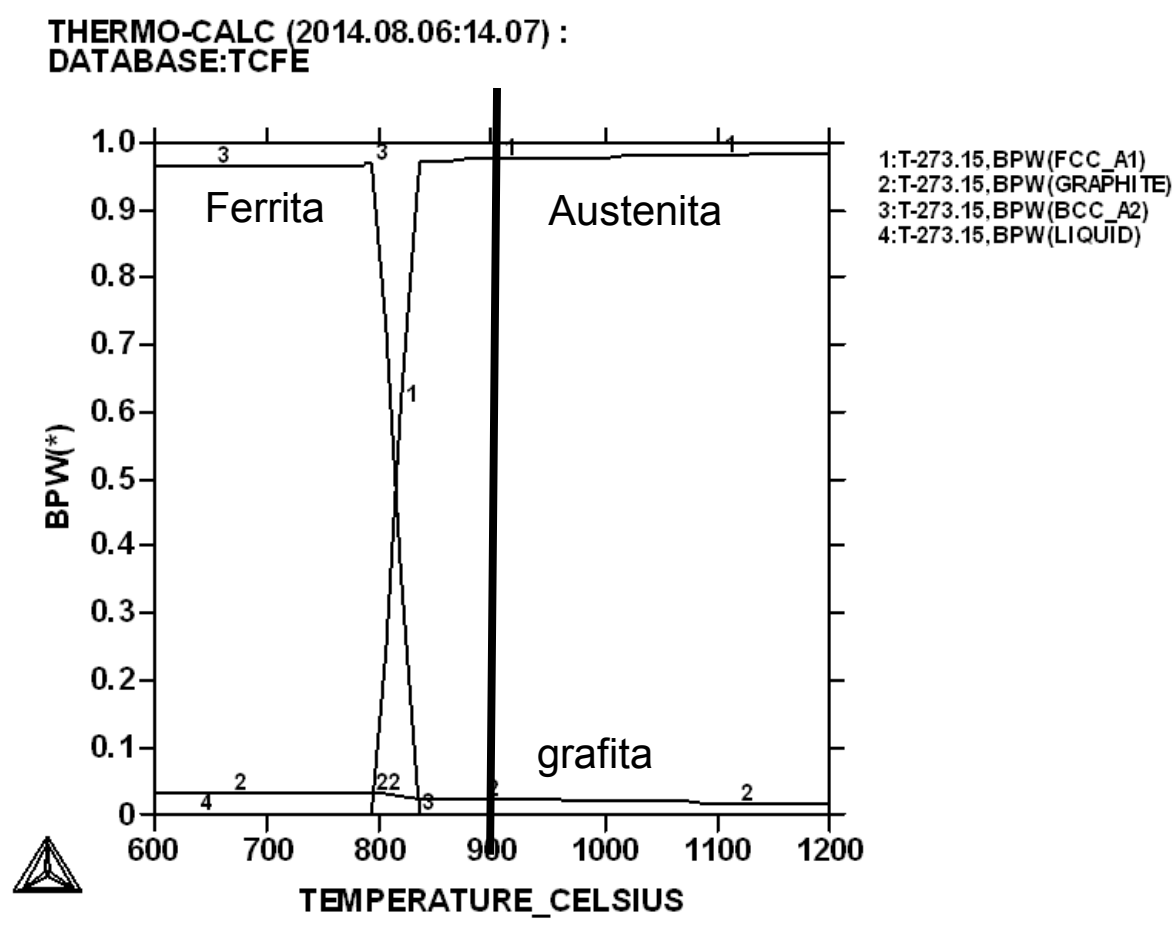

Figura 3 - Fases do ferro fundido cinzento e suas respectivas frações para diferentes temperaturas, simuladas no software Thermo-Calc®.

Os ensaios de dilatometria foram feitos no dilatômetro de têmpera Bähr DIL 805A no Laboratório de Transformações de Fases, situado no Departamento de Engenharia Metalúrgica da Universidade de São Paulo. Os corpos de prova utilizados no dilatômetro possuíam as dimensões $\varnothing 4 \mathrm{~mm} \times 10 \mathrm{~mm}$.

As amostras ensaiadas no dilatômetro Bähr tiveram o ciclo térmico completo executado no próprio equipamento (austenitização e revenimento), como esquematizando na Figura 4. O aquecimento foi realizado a uma taxa de $20{ }^{\circ} \mathrm{C} / \mathrm{s}$ até a temperatura $900{ }^{\circ} \mathrm{C}$, a qual foi mantida durante $120 \mathrm{~s}$ antes do rápido resfriamento à taxa de $100^{\circ} \mathrm{C} / \mathrm{s}$ utilizando gás hélio. Na sequência, para a etapa de revenimento, as amostras foram aquecidas a uma taxa de $20^{\circ} \mathrm{C} / \mathrm{s}$ até $650{ }^{\circ} \mathrm{C}$, temperatura mantida durante $5 \mathrm{~h}$ antes do resfriamento sob a taxa de $65^{\circ} \mathrm{C} / \mathrm{s}$ com gás hélio.

A dilatação linear foi comparada com a mudança de volume, obtida utilizando o método de Arquimedes. O teste de densitometria foi feito utilizando uma balança com 4 casas de resolução para a obtenção da massa, um fio de cobre foi utilizado para amarrar a amostra e um béquer com água. Pesa-se a amostra saturada com água 
(amostra úmida removendo apenas o excesso com um papel) e a massa imersa em água. Medindo a diferença de massas e tendo a densidade do líquido (água) é possível determinar a densidade do corpo de prova analisado.

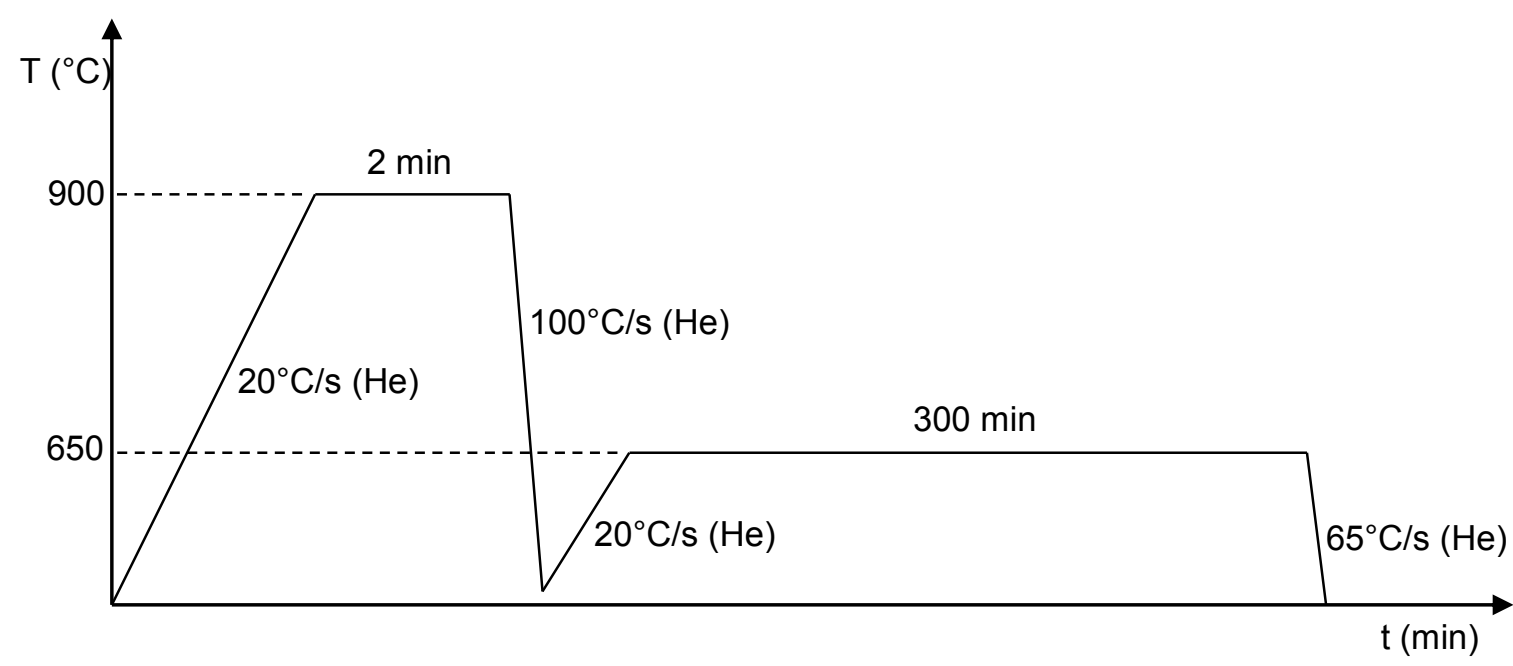

Figura 4 - Ciclo térmico utilizado nas amostras de ferro fundido cinzento nos ensaios de dilatometria

Para as etapas de quantificação das partículas de grafita, medida das durezas e determinação da fração volumétrica de grafita secundária, amostras com as dimensões de $9,5 \mathrm{~mm} \times 9,5 \mathrm{~mm} \times 4 \mathrm{~mm}$, foram submetidas a tratamentos de austenização em banho de sal a $900{ }^{\circ} \mathrm{C}$ por uma hora, seguido de têmpera em óleo. O posterior tratamento de revenimento foi conduzido na temperatura de $650{ }^{\circ} \mathrm{C}$ por 3 , $6,9,30,60,90,120,165,240$ e 300 minutos, novamente em banho de sal. As amostras tratadas foram preparadas metalograficamente e caracterizadas por microscopia eletrônica de varredura. Os fornos poço equipados com retortas de sais de tratamentos térmico encontram-se no Laboratório de Transformações de Fases do Departamento de Engenharia Metalúrgica da Escola Politécnica da Universidade de São Paulo, enquanto o durômetro utilizado na avaliação mecânica dos materiais encontra-se no Laboratório de Caracterização Microestrutural Hulbertus Colpaert, situado no mesmo Departamento. 


\subsection{RESULTADOS E DISCUSSÃO}

\subsubsection{Caracterização microestrutural das amostras}

\subsubsection{Amostra como recebida}

Amostras preparadas metalograficamente foram observadas sem ataque com o objetivo de se caracterizar inclusões e a morfologia da grafita formada durante a solidificação. Para caracterização dos microconstituintes presentes na matriz do material o reagente Nital $2 \%$ foi utilizado para execução do ataque metalográfico.

A morfologia da grafita no ferro fundido cinzento recebido apresentou-se heterogênea (Figura 5). Nota-se a presença de grafita nas formas lamelar e dos tipos $A, B$ e $D$.

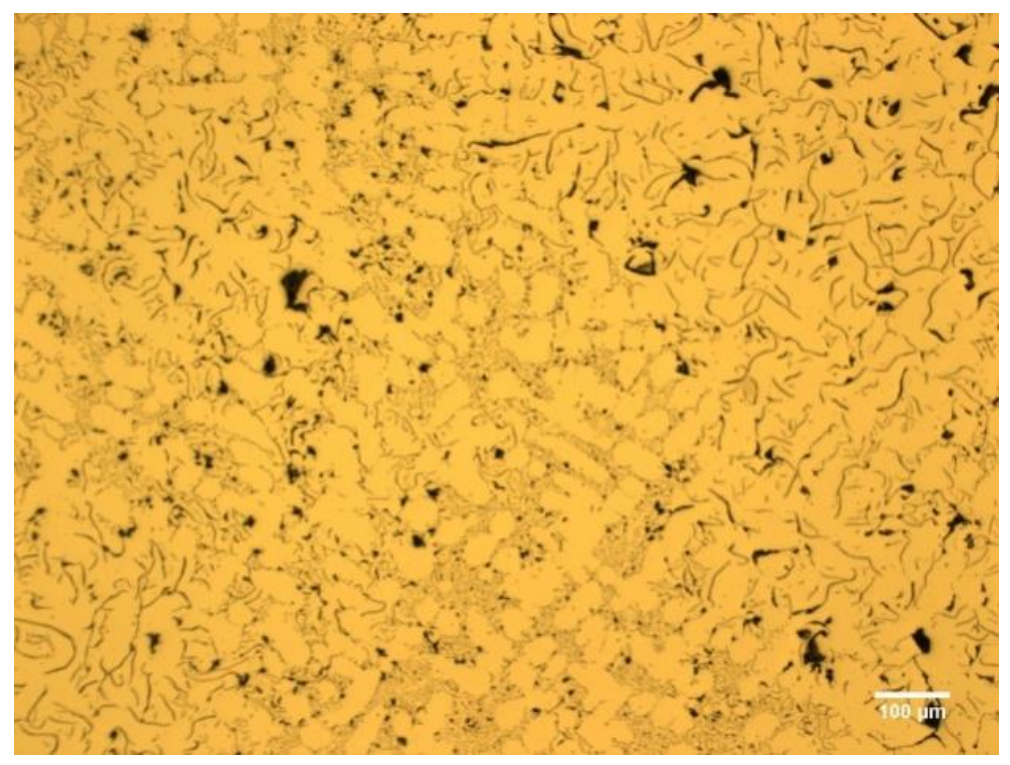

Figura 5- Microestrutura do ferro fundido cinzento sem ataque, na condição como recebida.

Após o ataque metalográfico, os braços de dentritas revelaram-se serem constituídos de perlita, como é mostrado na Figura 6. Na região interdendrítica é possível observar grafita lamelar dos tipos $\mathrm{A}$ e $\mathrm{D}$ e inclusões de sulfeto de manganês (microconstituinte cinza). 
(a)

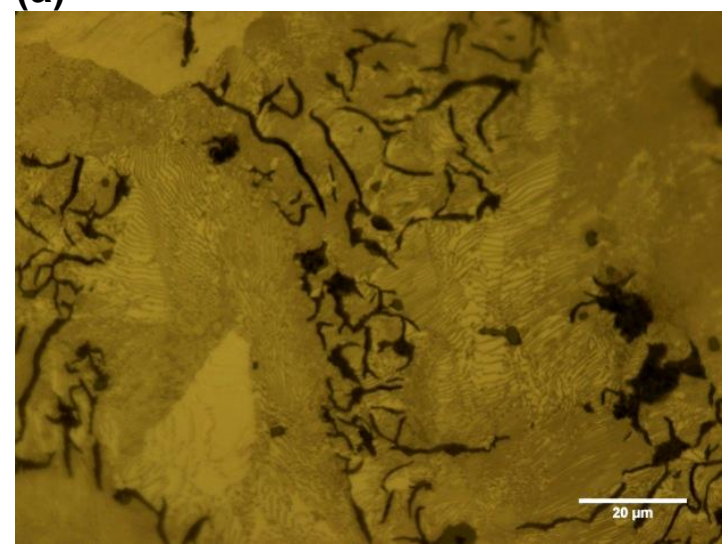

Figura 6- Microestrutura do FCZ (a) e FCZ (b) atacadas com Nital 2\%, na condição como (b)

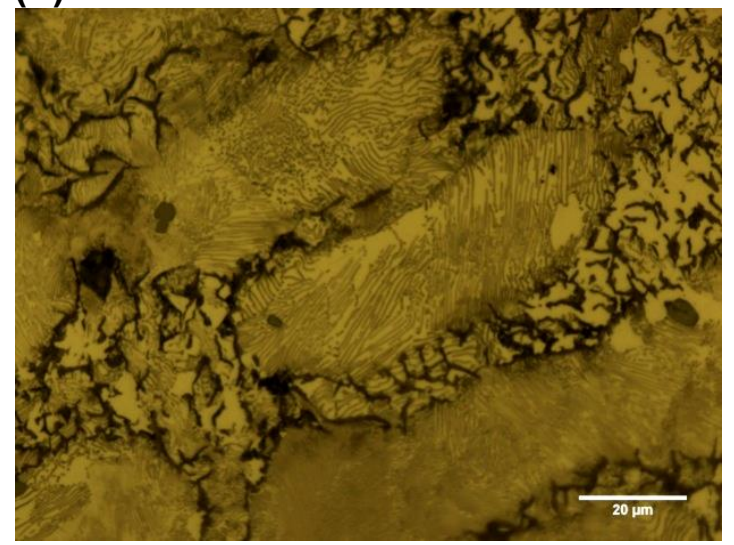

recebida.

\subsubsection{Testes de dilatometria}

\subsubsection{Austenitização a $900^{\circ} \mathrm{C}$ e têmpera}

A Figura 7 representa a curva completa de um ensaio de dilatometria, compreendendo as etapas de austenitização, têmpera e revenimento. A variação de dilatação total da amostra foi igual a $44 \mu \mathrm{m}$, porém esta dilatação é representativa de todas as transformações inerentes ao material, como formação de martensita, enriquecimento em carbono da autenita retida, perda da tetragonalidade da martensita durante o revenimento, formação de carbonetos e grafitização secundária. Durante a transformação martensítica a amostra expandiu $49 \mu \mathrm{m}$, no entanto uma fração de austenita não foi convertida em martensita. $O$ estudo das reações originadas durante o tratamento de revenimento serão apresentados no ítem 4.3.3.1.

\subsubsection{Etapa de austenitização}

A Figura 9 mostra a curva temperatura em função da dilatação correspondente ao tratamento de austenitização a $900{ }^{\circ} \mathrm{C}$ e têmpera utilizando o dilatômetro Bähr. Durante a etapa de aquecimento é possível identificar uma contração iniciada em 802 ${ }^{\circ} \mathrm{C}$ e terminada em $832{ }^{\circ} \mathrm{C}$, muito provavelmente correspondente à dissolução da matriz e formação de austenita (Figura 9b). Na etapa de resfriamento (Figura 9c), por sua vez, uma súbita expansão é detectada na temperatura de $207^{\circ} \mathrm{C}$, neste caso 
correspondente ao início da transformação martensítica (i.e., trata-se da temperatura Ms).

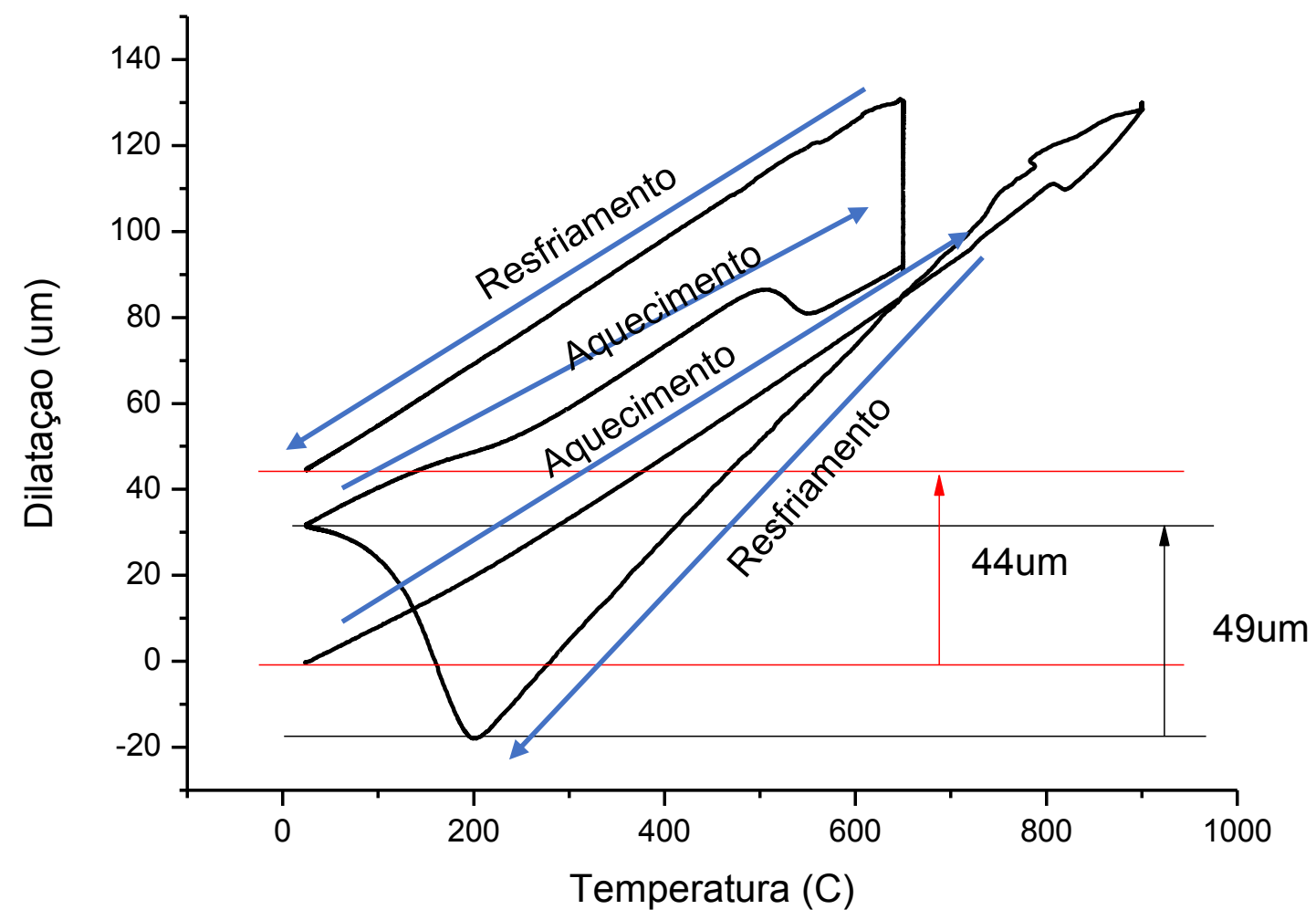

Figura 7- Curva completa obtidas por dilatometria, compreendendo as etapas de austenitização, têmpera e revenido de um ferro fundido cinzento.

Por finalidade de comparação, a temperatura Ms também foi estimada utilizando a equação empírica de Andrews [30], adaptada por Yakubtsov e Purdy [31] para a adição de silício (equação (1)). Esta equação tem como parâmetros as porcentagens mássicas dos elementos de liga na austenita que dará origem à martensita. Por sua vez, a composição química da austenita na temperatura de austenitização $\left(900^{\circ} \mathrm{C}\right.$ ) foi determinada por cálculos termodinâmicos executados com o banco de dados TCFE no software Thermo-Calc®. A composição da austenita em equilíbrio nesta temperatura, obtida pelo procedimento descrito, é mostrada na Tabela 2.

$$
\operatorname{Ms}\left[{ }^{\circ} \mathrm{C}\right]=539-423 \mathrm{C}-30,4 \mathrm{Mn}-12,1 \mathrm{Cr}-7,5 \mathrm{Mo}-7,5 \mathrm{Si}
$$


A temperatura Ms calculada pela equação de Andrews foi igual a $203{ }^{\circ} \mathrm{C}$, valor razoavelmente próximo ao determinado pelo experimento de dilatometria.

Tabela 2 - Simulação em Thermo-Calc® da composição química da austenita em equilíbrio a $900{ }^{\circ} \mathrm{C}$ de um ferro fundido cinzento.

\begin{tabular}{|c|c|c|c|c|c|c|}
\hline $\mathrm{C}$ & $\mathrm{Si}$ & $\mathrm{Mn}$ & $\mathrm{P}$ & $\mathrm{S}$ & $\mathrm{Cr}$ & $\mathrm{Cu}$ \\
\hline 0,726 & 2,878 & 0,239 & 0,041 & $2,955.10^{-7}$ & 0,031 & 0,465 \\
\hline
\end{tabular}

A porcentagem de carbono na austenita em função da temperatura foi estimada usando o ThermoCalc® (Figura 8). A porcentagem de carbono na austenita em função da temperatura aumenta linearmente. Usando a equação de Andrews para estimar o Ms e fixando os outros elementos de liga, o Ms apresenta situação oposta à concentração de carbono na austenita.

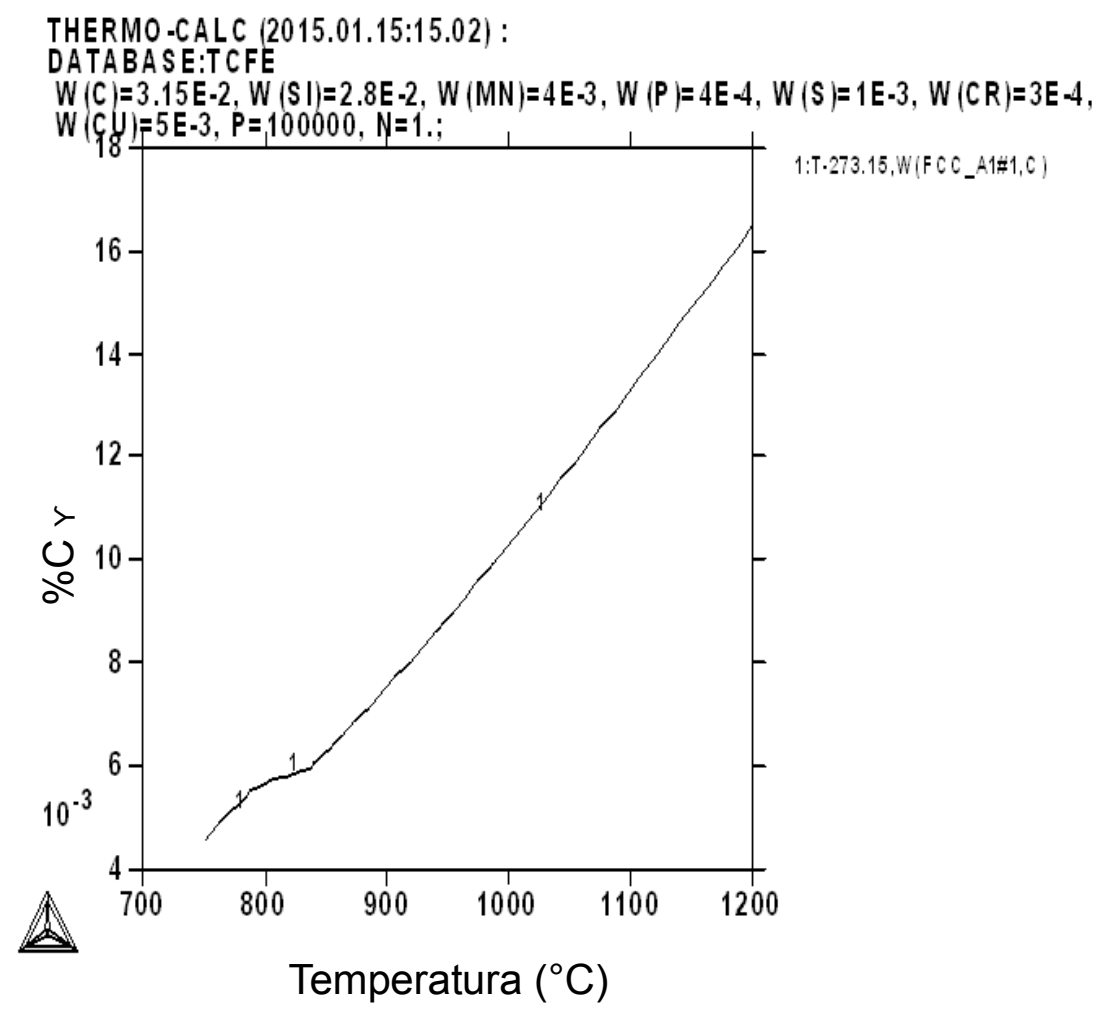

Figura 8 - Porcentagem de carbono de $\mathrm{C}$ na austenita em diferente temperaturas. 


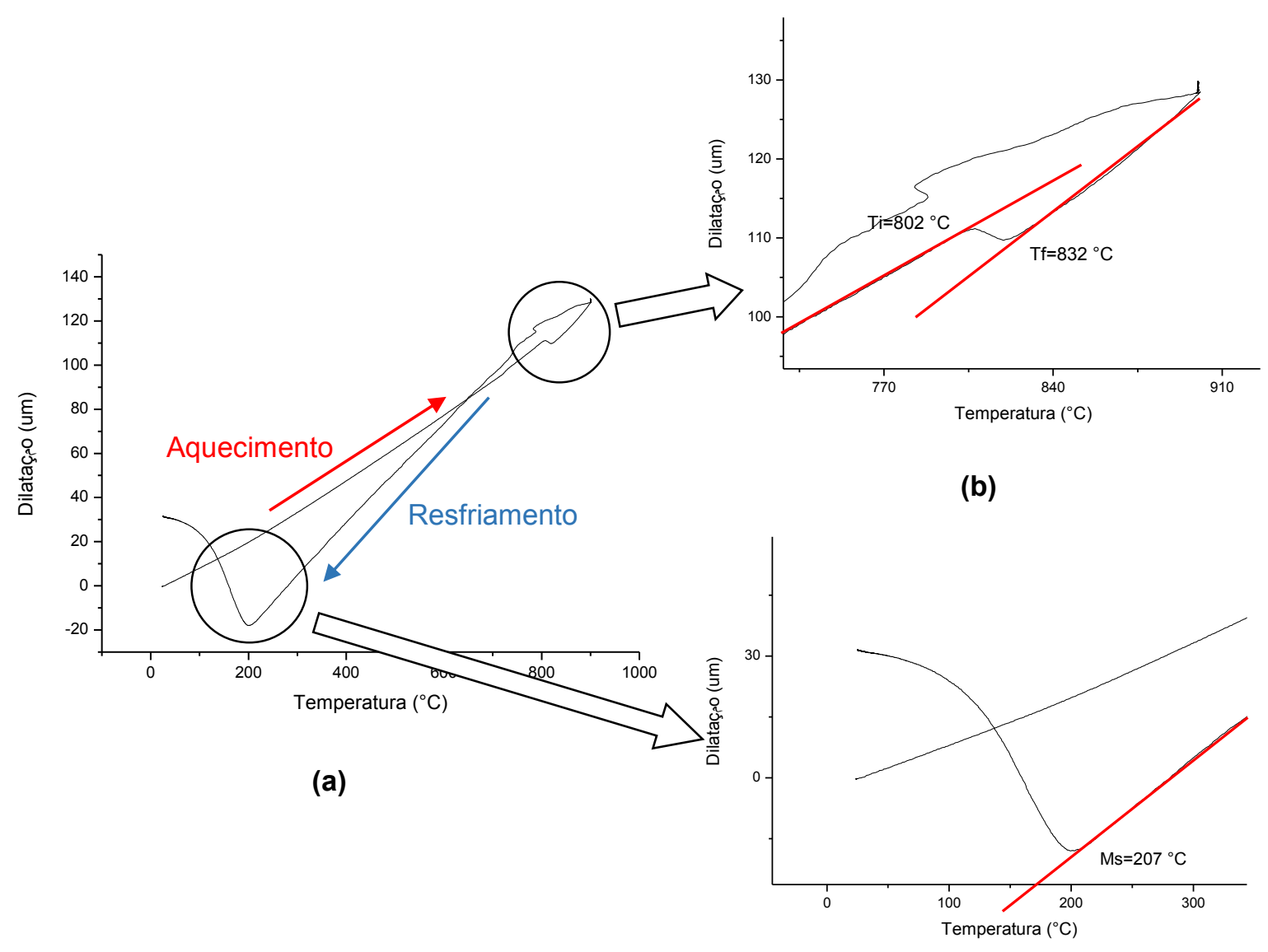

(c)

Figura 9- (a) curva de dilatometria obtidos durante a etapa de aquecimento e resfriamento a $900{ }^{\circ} \mathrm{C}$ de FCZ2, obtidos no dilatômetro Bähr. (b) início e fim da austenita. (c) início da transformação martensítica

\subsubsection{Caracterização microestrutural das amostras obtidas por dilatometria}

Os resultados obtidos nas curvas de dilatação versus tempo de dilatometria (Figura 10), mostraram inflexões durante a primeira etapa de aquecimento (transformação $\alpha \rightarrow \gamma$ ), no resfriamento (Ms) e no segundo aquecimento.

Os dados de dilatação da contração observada no reaquecimento (segundo evento) foram selecionados e derivado, como mostra Figura 11. Indicando uma transformação entre 500 a $560^{\circ} \mathrm{C}$.

Foram identificados três principais eventos durante a segunda etapa de aquecimento (regiões numeradas na Figura 10). Para identificar as transformações correspondentes a estes eventos, foram empregados ciclos térmicos interrompidos no momento da transformação. No momento em que a transformação ocorrera, a microestrutura foi "congelada" resfriando rapidamente a amostra com gás He a uma taxa de $100^{\circ} \mathrm{C} / \mathrm{s}$. 


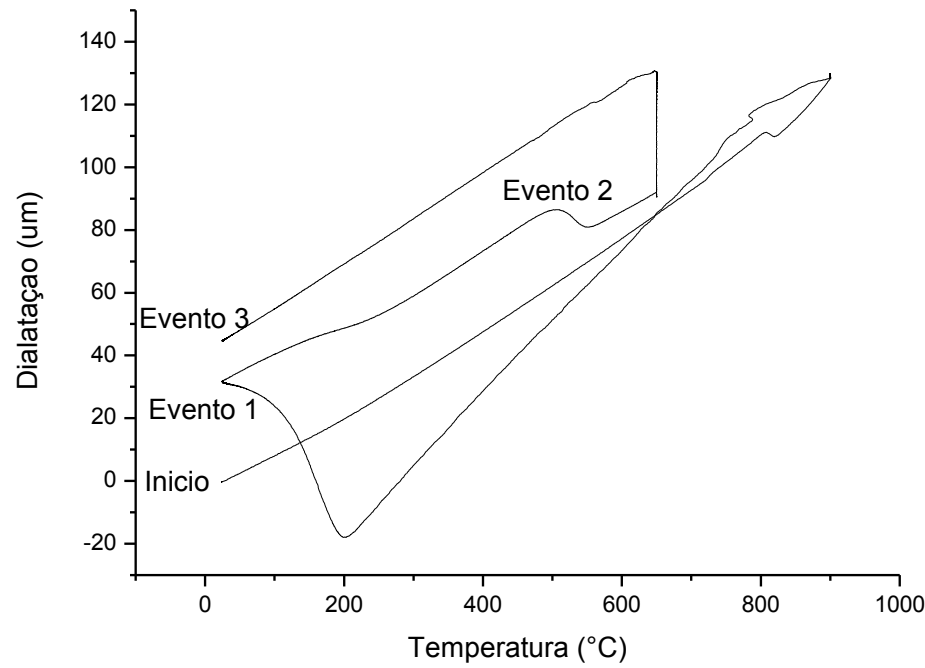

Figura 10- Curva de dilatometria da amostra de ferro fundido cinzento. Caracterização microestrutural das regiões numerada no gráfico.

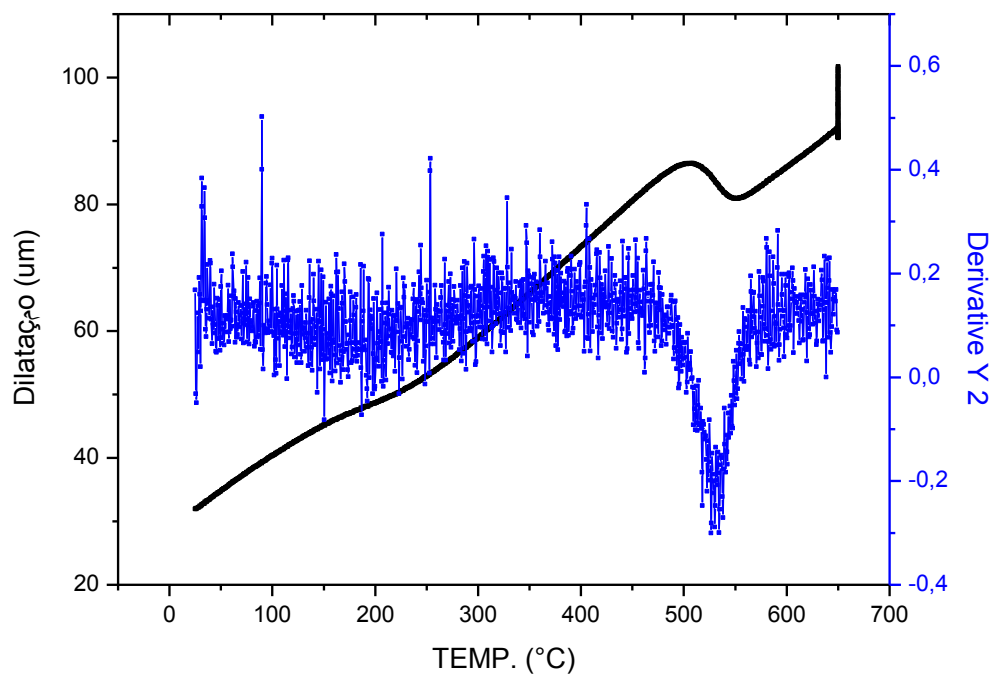

Figura 11- Curva de dilatometria da amostra de ferro fundido cinzento. Dados de dilatação do evento 2.

As amostras correspondentes aos eventos 1, 2 e 3 foram preparadas metalograficamente e caracterizadas por MO e MEV - FEG (field emission gun scanning electron microscopy). A metalografia correspondente ao evento 1 da Figura 10 corresponde à Figura 12: nota-se a presença de inclusões de sulfeto de manganês, grafita lamelar e matriz predominantemente composta de martensita maclada. 


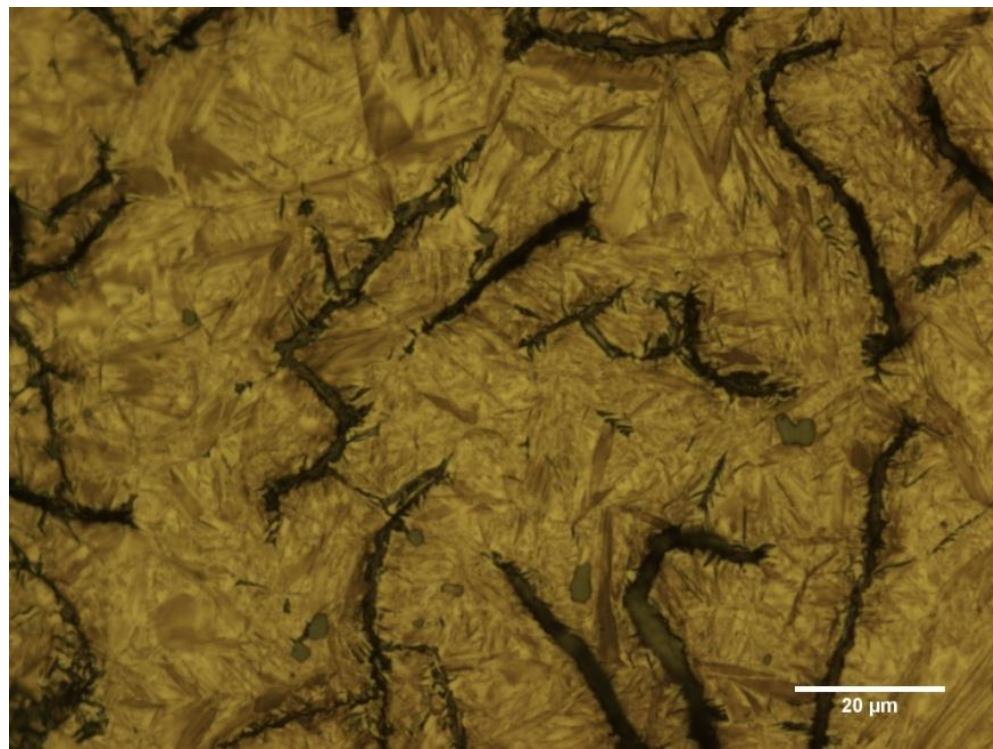

Figura 12- Microestrutura do FCZ atacadas com Nital $2 \%$, austenitizada a $900{ }^{\circ} \mathrm{C}$ e resfriada rapidamente.

A micrografia da Figura 13 corresponde à amostra cujo ciclo térmico foi interrompido na temperatura de $560^{\circ} \mathrm{C}$ por resfriamento rápido com gás He, logo após o evento 2 da Figura 10: nota-se a presença de inclusões de sulfeto de manganês, grafita lamelar dispersa em matriz de martensita, as regiões claras são austenita retida. A confirmação da presença de austenita retida observada na micrografia da Figura 13 foi feita a partir da comparação dos espectros de raio-X (RX) de amostras dos eventos 1 e 2, como pode ser observado na Figura 15. A Figura 15a e Figura 15b, representam, respectivamente, os espectros de raios $\mathrm{X}$ da amostra temperada $\mathrm{e}$ temperada e revenida.

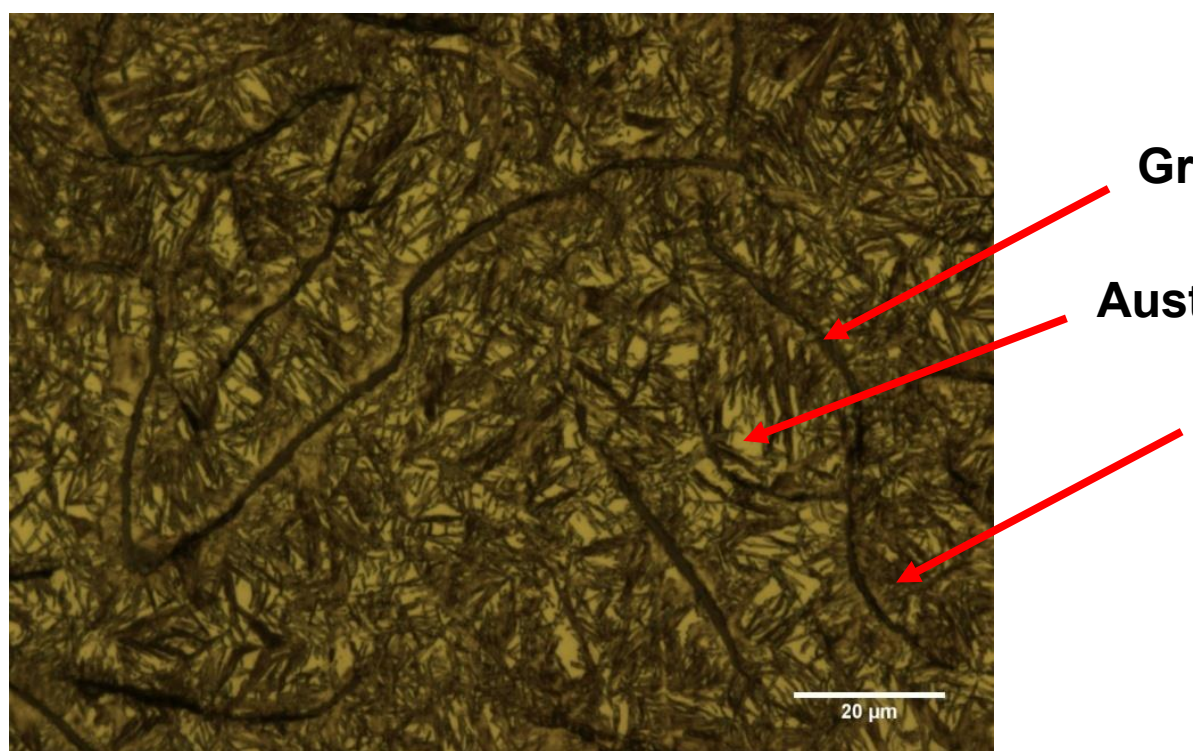

Grafita lamelar

Austenita retida

Martensita

revenida

Figura 13- Microestrutura do FCZ2 atacadas com Nital $2 \%$, austenitizada a $900{ }^{\circ} \mathrm{C}$, temperada e revenida a $560{ }^{\circ} \mathrm{C}$ e resfriadas rapidamente. 
As amostras apresentadas na Figura 12 e Figura 13 foram caracterizadas usando MEV-FEG. A Figura 14a apresenta a amostra temperada e a Figura 14b a amostra temperada e revenida. Comparando a microestrutura das duas amostras verifica-se a presença de matriz martensítica em ambas; no entanto a martensita da amostra temperada e revenida corresponde a uma martensita revenida, ou seja, o carbono da martensita se difunde para a austenita retida, enriquecendo a austenita retida em carbono.
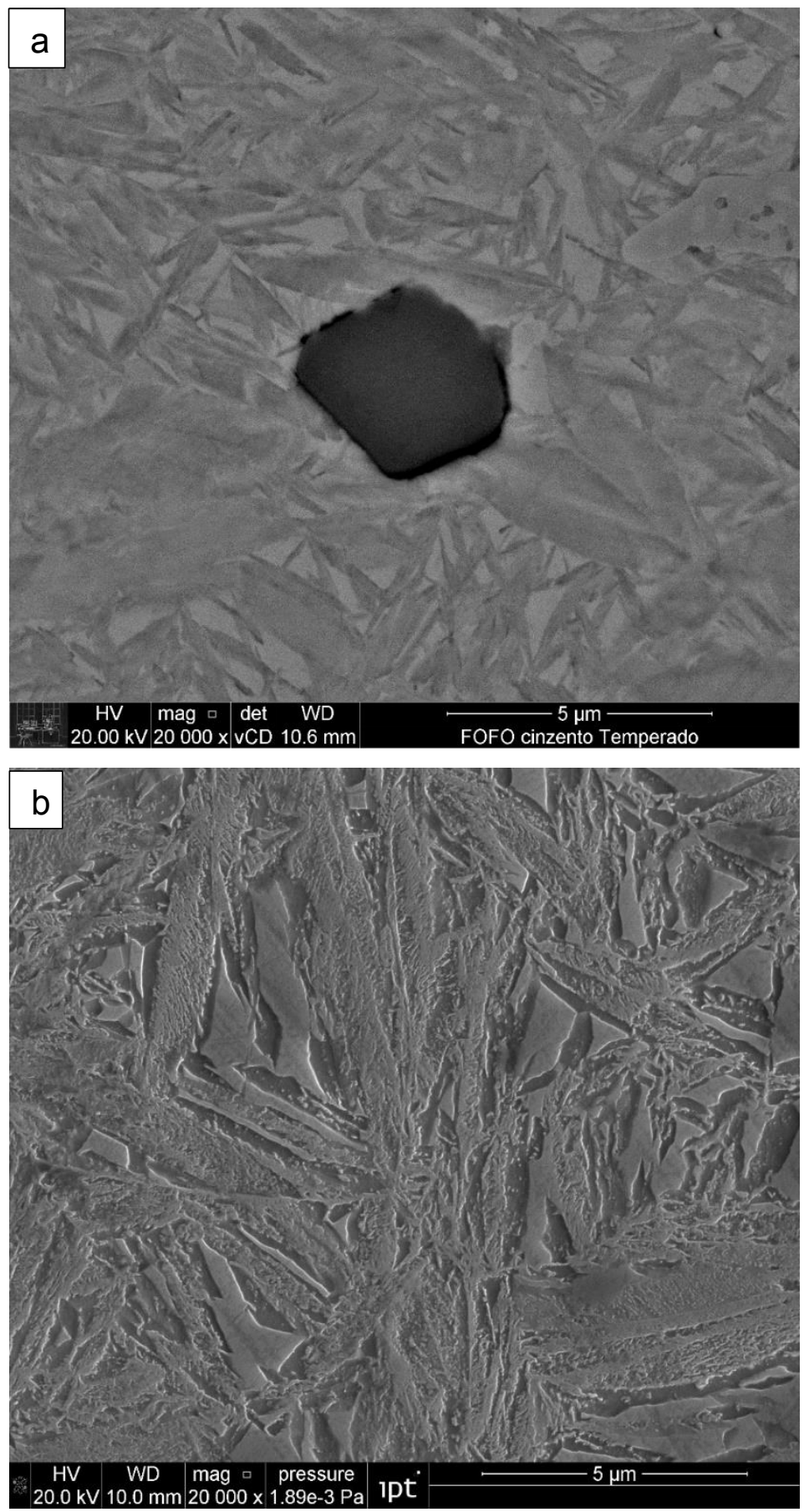

Figura 14 - amostra de ferro fundido cinzento caracterizadas por (FEG). (a) amostra temperada; (b) amostra temperada e revenida. 
As frações de austenita retida na amostra temperada e temperada e revenida foram calculadas usando a mesma metodologia proposta na teoria [32]. As frações de austenita foram determinadas pela integração de três picos da mesma fase, procedimento este efetuado para evitar possíveis influencias de textura. A fração volumétrica foi estimada pela equação 2 e a integral dos picos foi calculada numericamente pelo software Origin. O procedimento utilizado para a determinação da fração de austenita pode ser acompanhada no ANEXO A.

$$
f_{\gamma R}=\frac{\frac{1}{n_{\gamma}} \sum_{1}^{n} \frac{I_{\gamma}^{h k l}}{R_{\gamma}^{h k l}}}{\frac{1}{n_{\alpha}} \sum_{1}^{n} \frac{I_{\alpha}^{h k l}}{R_{\alpha}^{h k l}}+\frac{1}{n_{\gamma}} \sum_{1}^{n} \frac{I_{\gamma}^{h k l}}{R_{\gamma}^{h k l}}+f_{\theta}}
$$

Onde: $I_{\alpha}^{h k l}$ e $I_{\gamma}^{h k l}$ são as integrais dos picos das intensidades de martensita e austenita; na e $\mathrm{n} \gamma$ a quantidade de picos correspondentes as linhas hkl dos picos das integrais que foram medidas; $R_{\alpha}^{h k l} e R_{\gamma}^{h k l}$ as intensidades obtidas em amostras padrões de austenita e martensita [32] (Tabela 3); f $f_{\theta}$ é a fração de carbonetos.

Tabela 3 - Intensidades obtidas por amostras padrão para a austenita e martensita usando radiação de $\mathrm{Cu}[32]$

\begin{tabular}{|c|c|c|c|}
\hline \multicolumn{2}{|c|}{ Austenita } & \multicolumn{2}{c|}{ Martensita } \\
\hline hkl & Intensidade & hkl & Intensidade \\
\hline 111 & 74,52 & 110 & 36,94 \\
\hline 200 & 69,62 & 200 & 30,52 \\
\hline 220 & 55,88 & 211 & 26,28 \\
\hline 311 & 49,17 & 220 & 23,28 \\
\hline 222 & 47,37 & 310 & 21,07 \\
\hline 400 & 41,66 & \multicolumn{2}{|}{} \\
\cline { 1 - 2 } & \multicolumn{3}{|l}{} \\
\cline { 1 - 2 } & &
\end{tabular}

A fração de austenita retida nas amostras temperada e temperada e revenida foi de $12 \%$ e $8 \%$, respectivamente. A redução da concentração de austenita retida durante o revenimento, da ordem de $4 \%$ pode estar relacionada a decomposição da austenita retida em ferrita bainítica e cementita ou ferrita bainítica e austenita enriquecida em carbono.

A concentração de carbono na austenita nas amostras temperada e temperada e revenida foram estimadas. O parâmetro de rede da austenita foi calculado a partir 
dos dados de difração de raios-X, utilizando a lei de Bragg (equação 3) e a equação 4 que correlaciona o parâmetro de rede com a distância interplanar e os índices de Miller de um dado plano cristalino [32]. Desconsiderando o efeito dos elementos de liga substitucionais sobre o parâmetro de rede da austenita, o teor de carbono da austenita foi estimado pela equação 5 [32]. O teor de carbono na amostra temperada e da temperada e revenida passou respectivamente de 1,036 para 1,315 \%. Verificouse que houve um aumento de $0,3 \%$ de carbono durante o tratamento de revenimento. Esse resultado mostra que ocorre partição do carbono da martensita para a austenita retida. Os cálculos podem ser acompanhados no ANEXO B.

$$
\begin{gathered}
n \lambda=2 d \operatorname{sen} \Theta \\
\frac{1}{d^{2}}=\frac{h^{2}+k^{2}+l^{2}}{a^{2}} \\
a_{\gamma}=3,555+0,044 w_{c}^{\gamma}
\end{gathered}
$$

Apesar de não ter sido possível detectar a presença de carbonetos nos difratogramas de raios $X$ (Figura 15), possivelmente pela pequena quantidade, trabalhos recentes mostraram que durante o tratamento de revenimento a $400{ }^{\circ} \mathrm{C}$ em dois aços com teores de carbono diferentes, 0,59 e 1,07 apresentaram evidencias de formação de carboneto, o que não impediu que ocorresse também partição de carbono entre a martensita e a austenita retida [33].

Caballero [34] em um aço bainítico de alto teor de silício durante o tratamento de revenimento após austêmpera em testes de dilatometria, verificou contração semelhante ao evento 2 observado neste trabalho. Amostras com tratamento interrompido durante a primeira contração durante o aquecimento foram analisadas por microscopia de varredura (MEV) e raios-X. As micrografias por MEV revelaram a presença de partículas de cementita e ferrita bainítica, concluindo que a austenita retida foi transformada em ferrita e cementita. Caballero porém não relatou o enriquecimento de carbono da austenita observado no nosso trabalho.

A contração observada (evento 2 - Figura 10) por dilatometria pode então estar relacionada tanto à partição de $\mathrm{C}$ para a austenita retida como à precipitação de cementita, no interior da martensita, reduzindo o teor de $\mathrm{C}$ em solução na martensita e consequentemente o parâmetro de rêde assim como a tetragonalidade da mesma, 
(a)

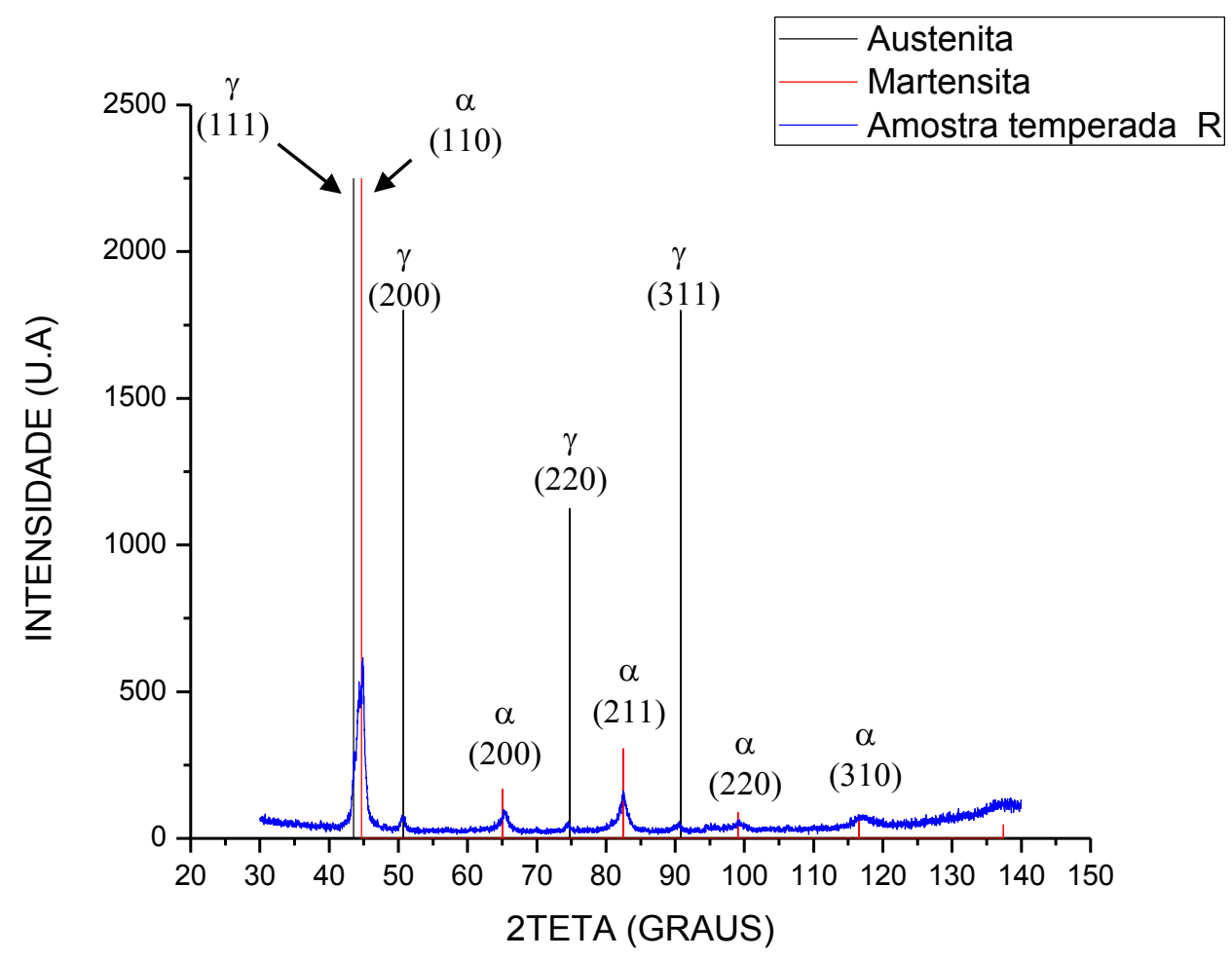

(b)

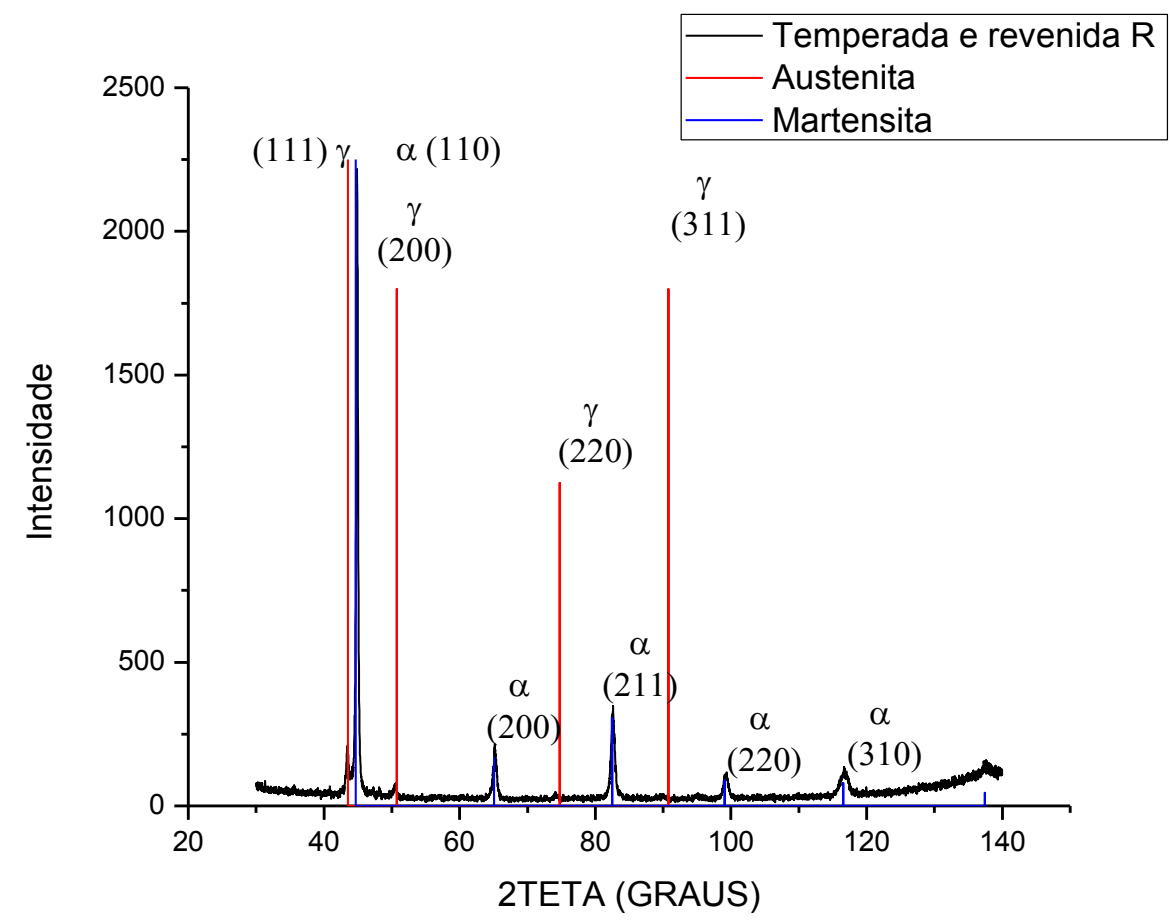

Figura 15- Espectro de raios-x de uma amostra de ferro fundido cinzento. (a) espectro da amostra temperada ; (b) temperada e revenida. a é martensita e y é austenita. 
como ocorre no tratamento de têmpera e partição (Q\&T, quenching and partition [35]).

Seguindo a curva de revenimento da martensita para aços proposto por Speich [36] (Figura 16), durante o aquecimento do revenimento a $650{ }^{\circ} \mathrm{C}$ ocorre recristalização de ferrita, engrossamento de cementita e, ao mesmo tempo, seguindo o raciocínio proposto por Caballero, parte da austenita retida é transformada em cementita e ferrita, a austenita que não se transforma é enriquecida em carbono.

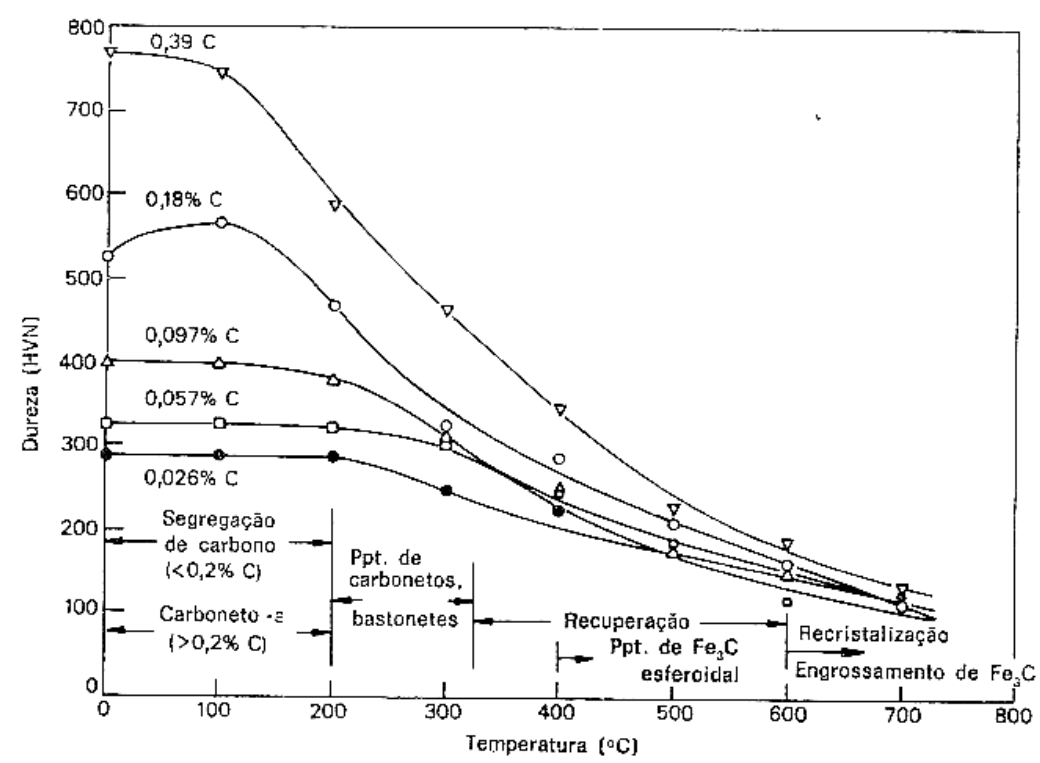

Figura 16 - Curva de revenimento da martensita [36].

A microestrutura resultante ao final do tratamento isotérmico pode ser visualizada na Figura 17, que corresponde ao evento 3 da Figura 10, nota-se a presença de inclusões de sulfeto de manganês, carbonetos, grafita lamelar e secundária de morfologia esferoidal em matriz ferrítica.
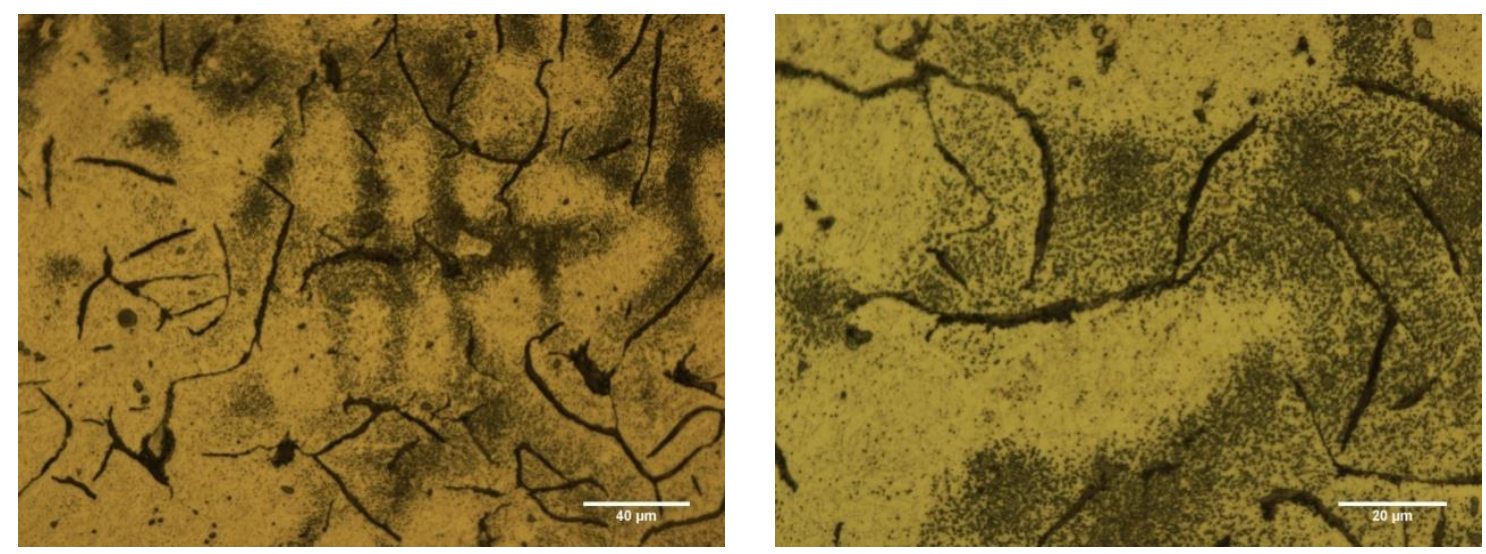

Figura 17- Microestrutura do FCZ2 atacadas com Nital $2 \%$, austenitizada a $900{ }^{\circ} \mathrm{C}$, temperada e revenidas a $650{ }^{\circ} \mathrm{C}$ durante $5 \mathrm{~h}$. 


\subsubsection{Revenimento a $650{ }^{\circ} \mathrm{C}$}

A cinética das reações originadas durante o revenimento foi estudada usando os resultados obtidos por dilatometria. O trecho correspondente ao tratamento isotérmico na curva dilatação versus tempo foi separado da curva completa (Figura 7) como pode ser observado na Figura 18.

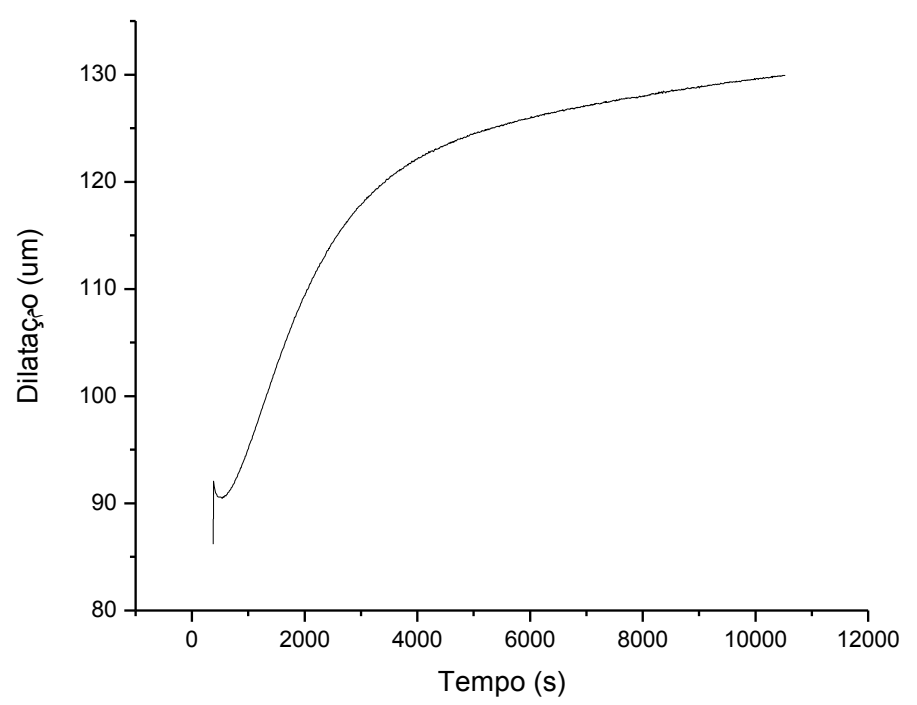

Figura 18- Trecho correspondente ao tratamento isotérmico a $650^{\circ} \mathrm{C}$ realizado no dilatômetro Bähr.

A fração transformada de grafita foi determinada a partir da regra da alavanca na curva dilatação versus tempo como descrito no artigo de SANTOS e MARRA [37]. A equação cinética foi ajustada pela equação 6 , sugerida por Burke [38] e análoga à equação de Johnson-Mehl-Avrami-Kolmogorov (JMAK) [39]. A equação utilizada se distingue de JMAK pela forma como a constante $K$ é definida. Na equação $6, K$ possui dimensão de tempo-1, enquanto na forma usual de representação da equação de JMAK, a constante possui dimensão de tempo-n. Burke relata que sob a ótica desta última situação, energias de ativação obtidas pela dependência de $K$ com a temperatura não podem ser comparadas diretamente com a energia obtida quando a constante possui dimensão de tempo-1. Dessa forma, conclui ele, é preferível evitar esta dificuldade utilizando a equação 6.

Na equação 6, Y é a fração transformada aparente de grafita tendendo ao equilíbrio, ou seja, corresponde à fração transformada em relação máxima porcentagem transformada. É importante perceber a distinção entre a definição de $Y$ 
e a fração volumétrica $V_{v}$. Y assume valores na faixa de 0 a $100 \%$, enquanto a fração volumétrica transformada de grafita, quantificada por metalografia quantitativa, assume valores máximos próximos a $10 \%$.

$$
\mathrm{Y}=1-\mathrm{e}^{(-\mathrm{Kt})^{\mathrm{n}}}
$$

Na curva de fração transformada aparente $(Y)$ versus tempo (Figura 19) foi feita a linearização da curva usando a seguinte fórmula:

$$
\ln \left(\ln \frac{1}{1-\mathrm{Y}}\right)=\mathrm{n} \cdot \ln (\mathrm{k})+\mathrm{n} \cdot \ln (\mathrm{t})
$$

O trecho linearizado corresponde a 0,3-0,95 da fração transformada, trecho linear da curva fração transformada versus tempo (Figura 20), o trecho selecionado foi linearizado segundo a equação 7 (Figura 20). A escolha de linearização a partir de 0,3 da fração transformada foi feita para caracterizar apenas o crescimento da grafita, e não a nucleação ou a esferoidização de carbonetos de revenido.

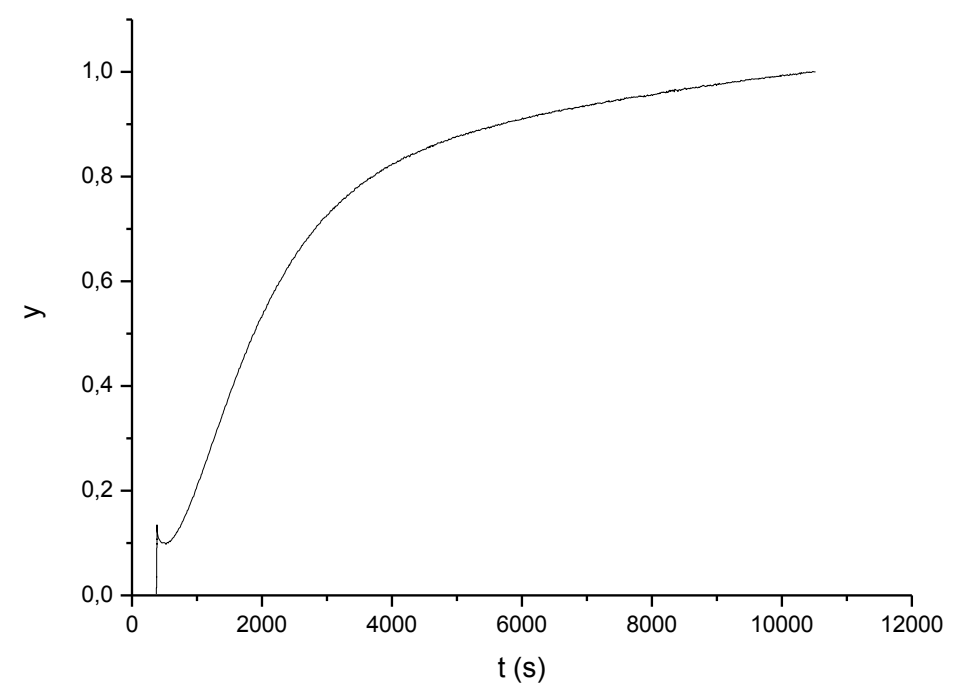

Figura 19 - Fração transformada de grafita aparente em função do tempo 


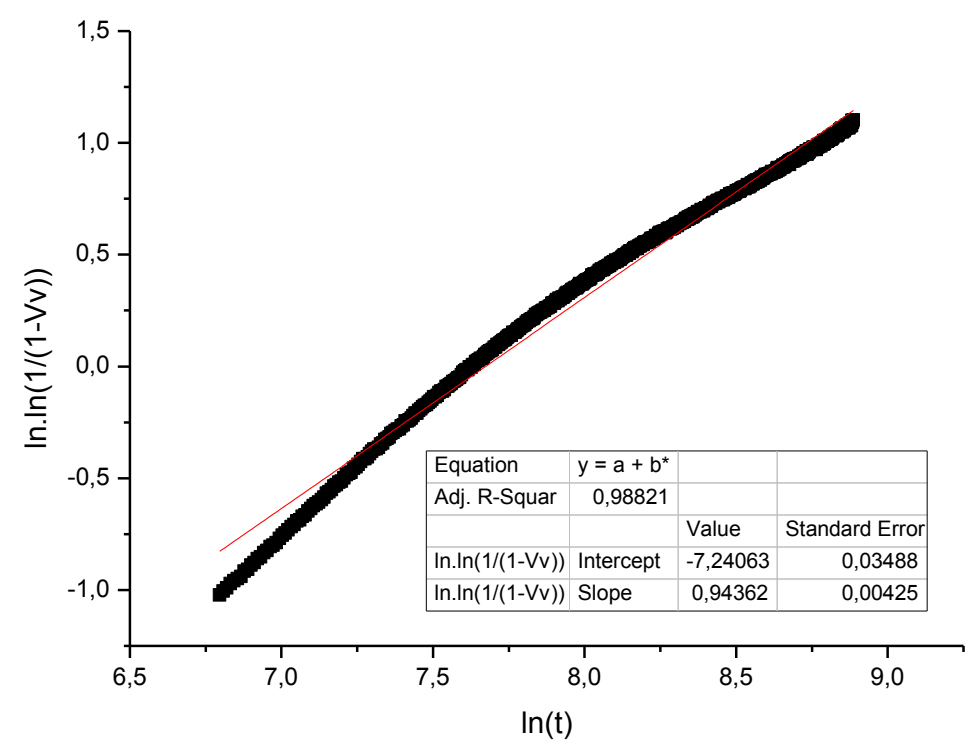

Figura 20- Linearização dos dados de dilatometria de ferro fundido na isoterma a $650^{\circ} \mathrm{C}$.

$K=7,17.10^{-4}$ e $n=0,94$

Segundo a literatura, valores de $n=1$, podem corresponder a nucleação de grafita em contornos de grão após saturação de locais de nucleação, para reações controladas pela interface ou crescimento de partículas por difusão com taxas de nucleação muito baixas ou nulas [39].

\subsubsection{Densitometria pelo método de Arquimedes}

A densidade da amostra de ferro fundido cinzento temperada a $900{ }^{\circ} \mathrm{C}$ durante uma hora e da amostra temperada a $900{ }^{\circ} \mathrm{C}$ durante uma hora e revenidas a $650{ }^{\circ} \mathrm{C}$ durante $5 \mathrm{~h}$ foi estimada usando o método de Arquimedes. As densidades foram respectivamente: $7,12 \mathrm{~g} / \mathrm{cm}^{3}$ e $7,04 \mathrm{~g} / \mathrm{cm}^{3}$; a massa seca e massa imersa na água pesados na balança analítica junto dos valores de densidades calculados encontramse na Tabela 4. 
Tabela 4 - Densidades calculadas usando o método de Arquimedes

\begin{tabular}{|c|c|c|c|c|}
\hline Tipo de TT & $\begin{array}{c}\text { Massa } \\
\text { seca }\end{array}$ & $\begin{array}{c}\text { Massa } \\
\text { imersa } \\
\text { em } \\
\text { água }\end{array}$ & $\begin{array}{c}\text { Densidade } \\
\text { calculada }\end{array}$ & $\begin{array}{l}\text { densidade } \\
\text { do líquido }\end{array}$ \\
\hline \multirow{3}{*}{ Temperado } & 31,070 & 26,711 & 7,121 & \multirow[t]{10}{*}{0,999} \\
\hline & 31,070 & 26,715 & 7,128 & \\
\hline & 31,070 & 26,714 & 7,126 & \\
\hline Média & 31,070 & 26,713 & 7,125 & \\
\hline Desvio padrão & 0,000 & 0,002 & 0,003 & \\
\hline \multirow{3}{*}{$\begin{array}{c}\text { Temperado e } \\
\text { Revenido a } 650^{\circ} \mathrm{C} \\
5 \mathrm{H}\end{array}$} & 18,331 & 15,730 & 7,040 & \\
\hline & 18,331 & 15,731 & 7,043 & \\
\hline & 18,331 & 15,731 & 7,044 & \\
\hline Média & 18,331 & 15,731 & 7,042 & \\
\hline Desvio padrão & 0,000 & 0,001 & 0,002 & \\
\hline
\end{tabular}

Considerando que a massa final é a soma das massas de grafita e de ferrita temos:

$$
\begin{gathered}
m_{T}=m_{\propto}+m_{G} \\
\rho_{T} \cdot V_{T}=\rho_{\alpha} \cdot V_{\alpha}+\rho_{G} \cdot V_{G}
\end{gathered}
$$

Dividindo por $\mathrm{V}_{\mathrm{T}}$, temos:

$$
\begin{gathered}
\rho_{T}=\frac{\rho_{\alpha} \cdot V_{\alpha}}{V_{T}}+\frac{\rho_{G} \cdot V_{G}}{V_{T}} \\
\rho_{T}=\rho_{\alpha} \cdot V_{v \alpha}+\rho_{G} \cdot V_{v G} \\
\rho_{T}=\rho_{\alpha} \cdot\left(1-V_{v G}\right)+\rho_{G} \cdot V_{v G}
\end{gathered}
$$

A fração volumétrica de grafita secundária foi determinada a partir da diferença entre a fração volumétrica de grafita no material temperado e temperado/revenido. Usando a densidade teórica da ferrita $\left(7,88 \mathrm{~g} / \mathrm{cm}^{3}\right)$ e da grafita $\left(2,223 \mathrm{~g} / \mathrm{cm}^{3}\right)$. A equação 12 foi usada para calcular a fração volumétrica de grafita, onde a densidade total $\left(\rho_{T}\right)$ uma hora foi substituída pela densidade do material temperado para determinar a fração volumétrica de grafita no material temperado; $\rho_{T}$ foi substituido pela densidade da amostra temperada e revenida para calcular a fração volumétrica de grafita na amostra temperada e revenida. A fração de grafita ( $\left.V_{V G}\right)$ no material temperado foi igual a 0,13 e no temperado e revenido foi igual a 0,15 . A fração 
calculada de grafita secundária usando o método de Arquimedes foi igual a 0,02.

A dilatação linear medida no dilatômetro foi comparada com as densidades obtidas usando o método de Arquimedes. O raciocínio utilizado para este cálculo foi o de conservação das massas; onde a massa final é igual a massa inicial. A dedução das equações segue nas equações 13-17.

$$
\begin{gathered}
m 1=m 2 \\
\rho_{1} \cdot V_{1}=\rho_{2} \cdot V_{2} \\
V_{2}=\frac{V_{1} \cdot \rho_{1}}{\rho_{2}} \\
\frac{\Delta V}{V_{1}}=\frac{V_{2}-V_{1}}{V_{1}} \\
\frac{\Delta V}{V_{1}}=\frac{\rho_{1}-\rho_{2}}{\rho_{2}}
\end{gathered}
$$

A partir da equação 17 , tendo os valores de densidade dos materiais com diferentes tratamentos térmicos calculados usando o método de Arquimedes foi possível determinar $\Delta V / \mathrm{V} 1$, onde $\rho 1$ é a densidade do material temperado $\left(7,12 \mathrm{~g} / \mathrm{cm}^{3}\right)$ e $\rho 2$ é a densidade do material temperado e revenido $\left(7,04 \mathrm{~g} / \mathrm{cm}^{3}\right)$. O valor de $\Delta \mathrm{V} / \mathrm{V} 1$ obtido é igual a 0,0128. Porém, para efeito de comparação, é necessário converter a variação volumétrica relativa $\Delta \mathrm{V} / \mathrm{V} 1$ para a respectiva variação linear relativa $\Delta \mathrm{L} / \mathrm{L} 1$. Isto pode ser feito pela aproximação $\Delta \mathrm{V} / \mathrm{V} 1 \sim 3 \Delta \mathrm{L} / \mathrm{L} 1$, relação cuja obtenção é conseguida tomando como modelo a dilatação do cubo representado na Figura 21 e a sequência de equações 18-26.
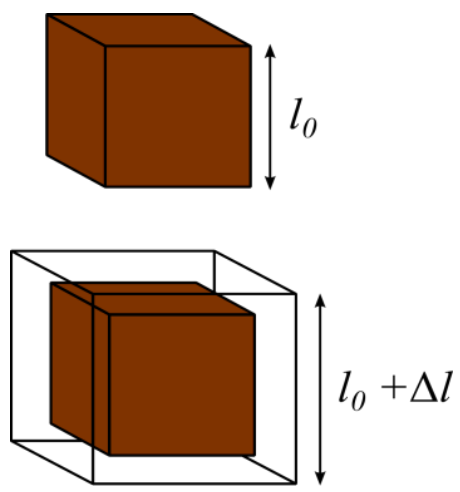

Figura 21 - Representação de um cubo, considerando a variação linear.

$$
L=\Delta L+L o
$$




$$
\begin{gathered}
V o=L o^{3} \\
V=L^{3} \\
V=\Delta V+V o \\
V o+V=(L o+\Delta L)^{3} \\
V o+V=L o^{3}+3 \cdot L o^{2} \cdot \Delta L+3 \cdot L o \cdot \Delta L^{2}+\Delta L^{3} \\
\frac{V o+V}{V o}=\frac{L o^{3}+3 \cdot L o^{2} \cdot \Delta L+3 \cdot L o \cdot \Delta L^{2}+\Delta L^{3}}{L o^{3}} \\
\frac{\Delta V}{V o}=3 \cdot \frac{\Delta L}{L o}+3 \cdot\left(\frac{\Delta L}{L o}\right)^{2}+\left(\frac{\Delta L}{L o}\right)^{3}
\end{gathered}
$$

Como $\Delta \mathrm{L} \ll<\mathrm{LO}$, os termos quadráticos e cúbicos podem ser desprezados, de modo que:

$$
\frac{\Delta V}{V o} \approx 3 \cdot \frac{\Delta L}{L o}
$$

Por meio da equação 26 foi possível calcular $\Delta \mathrm{L} / \mathrm{L} 1$, tendo-se obtido o valor de 0,00426. Na Figura 7, foi mostrado que a variação de comprimento total da amostra de FC nos testes de dilatometria foi igual a $44 \mu \mathrm{m}$. Dado o comprimento inicial da amostra de $10 \mathrm{~mm}$, conclui-se que a variação linear relativa obtida por dilatometria é equivalente a 0,0044 , resultado muito semelhante ao obtido utilizando o método de Arquimedes.

A partir do software Thermo-Calc® calculou-se a fração mássica de grafita no equilíbrio termodinâmico a $900^{\circ} \mathrm{C}(0,03)$ e $650{ }^{\circ} \mathrm{C}(0,04)$, a fração mássica de austenita a $900{ }^{\circ} \mathrm{C}(0,97)$ e ferrita a $650{ }^{\circ} \mathrm{C}(0,96)$. A densidade da grafita é igual a $2,223 \mathrm{~g} / \mathrm{cm}^{3}$, austenita $\left(8 \mathrm{~g} / \mathrm{cm}^{3}\right)$ e ferrita $\left(7,874 \mathrm{~g} / \mathrm{cm}^{3}\right)$, calculando a fração de volume de grafita na austenita e na ferrita pelas equações (27) e (28):

$$
\begin{gathered}
\mathrm{V}_{\mathrm{G} \alpha}=\frac{\frac{\mathrm{W}_{\alpha}}{\rho_{\alpha}}}{\frac{\mathrm{W}_{\alpha}}{\rho_{\alpha}}+\frac{\mathrm{W}_{\mathrm{G} \alpha}}{\rho_{\mathrm{G}}}} \\
\mathrm{V}_{\mathrm{G} \gamma}=\frac{\frac{\mathrm{W}_{\alpha}}{\rho_{\alpha}}}{\frac{\mathrm{W}_{\gamma}}{\rho_{\gamma}}+\frac{\mathrm{W}_{\mathrm{G} \gamma}}{\rho_{\mathrm{G}}}}
\end{gathered}
$$


em que:

- $V_{G a}=$ fração volumétrica de grafita na ferrita;

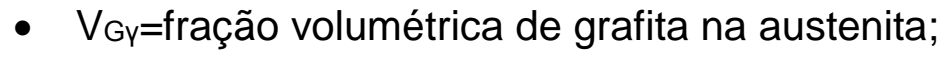

- $W_{\alpha}=$ fração mássica de ferrita;

- $W_{Y}=$ fração mássica de austenita;

- $W_{G}=$ fração mássica de grafita;

- $\rho_{\alpha}=$ densidade de ferrita;

- $\rho_{y}=$ densidade de austenita;

- $\rho G=d e n s i d a d e$ de grafita;

A diferença das frações volumétricas da grafita a 900 e $650{ }^{\circ} \mathrm{C}$ representa a fração volumétrica de grafita secundária, igual a 0,028 , resultado parecido com o resultado usando o método de Arquimedes.

A fração volumétrica de grafita e a quantidade de nódulos de grafita secundária por $\mathrm{mm}^{2}$ aumentam com o tempo de tratamento térmico. Após a formação dos núcleos de grafita secundária, ocorre o coalescimento (maturação de Ostwald) das partículas de grafita ou possivelmente sua dissolução para as grafitas primárias.

\subsubsection{Tratamentos térmicos em banho de sal}

A determinação da fração volumétrica e da quantidade de nódulos de grafita secundária nos tratamentos em banho de sal não foi eficiente para os tempos iniciais de tratamento térmico, pois a caracterização por MO impossibilitou a quantificação das micro-partículas. Em tempos maiores de tratamentos térmicos as partículas de grafita já são visíveis por MO e são mais fáceis de serem quantificados.

A formação de grafita secundária teve a maior quantidade de nódulos a partir dos tratamentos mais prolongados, após 300 min, com a média de 200 nódulos por $\mathrm{mm}^{2}$. Em quase todas as amostras observou-se a presença de pequenas partículas de sulfetos de manganês que facilmente poderiam ser confundidos com os nódulos de grafita. Resultado semelhante foi obtido no trabalho de Pimentel [25], onde foram feitos tratamentos térmicos no mesmo ferro fundido cinzento utilizado neste trabalho, utilizando diferentes temperaturas de autenitização $\left(850,900\right.$ e $\left.950{ }^{\circ} \mathrm{C}\right)$, diferentes temperaturas de envelhecimento $\left(650\right.$ e $\left.675^{\circ} \mathrm{C}\right)$ e diferentes tempos. No trabalho de 
Pimentel (Figura 22), a melhor condição de tratamento térmico foi o tratamento efetuado de austenitizacão a $950^{\circ} \mathrm{C}$ e revenimento a $650{ }^{\circ} \mathrm{C}$ em diferentes tempos [25]. O pico de nódulos $/ \mathrm{mm}^{2}$ foi em $5 \mathrm{~h}$.

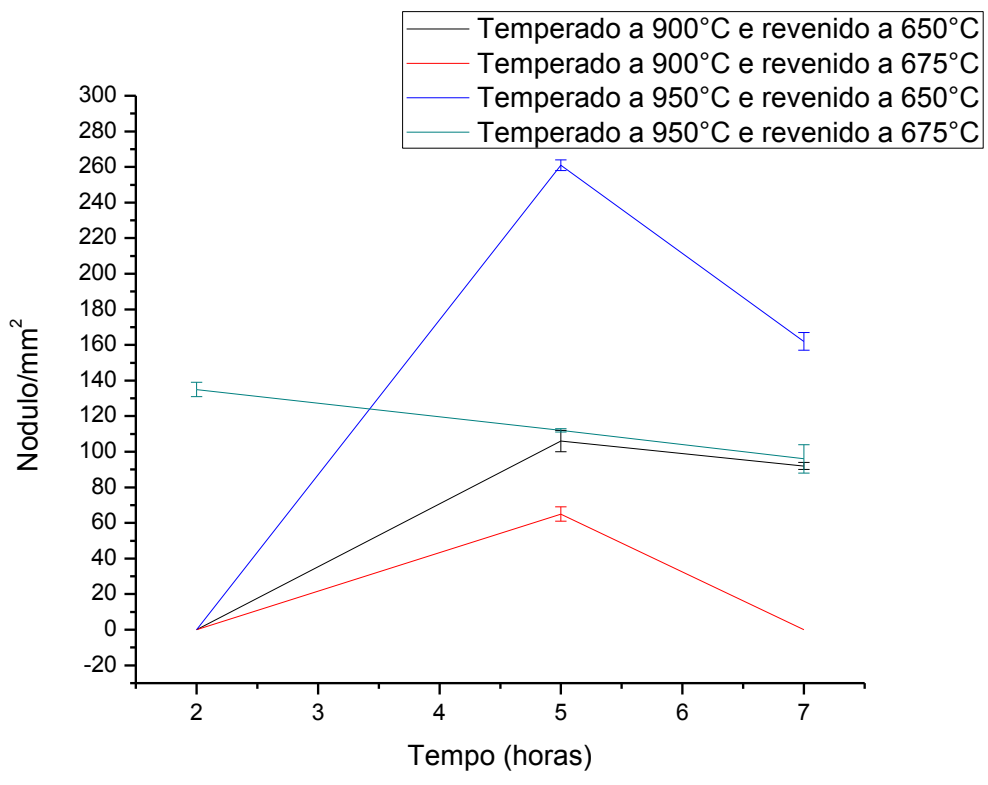

Figura 22 - nódulos/mm2 para diferentes condições de tratamentos térmicos [25].

A quantidade de 200 a 300 nódulos por $\mathrm{mm}^{2}$ é muito pequena, pois ferros fundidos nodulares revenidos nestas temperaturas apresentam valores maiores do que 1000 nódulos $/ \mathrm{mm}^{2}$ [12]. Tanto este trabalho, como o trabalho executado em paralelo de Pimentel [25], obtiveram poucos nódulos de grafita, ao contrário do que se esperava a partir dos resultados observados em ferros fundidos nodulares . Por este motivo não foram realizados ensaios tribológicos nestes materiais.

\subsubsection{Medidas de durezas vs tempo}

A dureza com diferentes tratamentos pode ser acompanhada na Tabela $5 \mathrm{e}$ Figura 23; ela diminui rapidamente nos primeiros três minutos de tratamento isotérmico $\left(650^{\circ} \mathrm{C}\right)$; depois permanece relativamente constante de 9 a 60 minutos de tratamento isotérmico e cai novamente a partir de $90 \mathrm{~min}$. 
Tabela 5- Dureza HB para ferro fundido cinzento, austenitizado a $900^{\circ} \mathrm{C}$ e revenido a $650^{\circ} \mathrm{C}$.

\begin{tabular}{|c|c|c|}
\hline Tempo (min) & Dureza (HB) & $\begin{array}{c}\text { Desvio } \\
\text { padrão }\end{array}$ \\
\hline 0 & 346 & 46 \\
\hline 3 & 214 & 18 \\
\hline 6 & 211 & 13 \\
\hline 9 & 173 & 23 \\
\hline 30 & 175 & 48 \\
\hline 60 & 170 & 14 \\
\hline 90 & 107 & 2 \\
\hline 120 & 126 & 10 \\
\hline 165 & 117 & 7 \\
\hline 240 & 98 & 16 \\
\hline 300 & 90 & 2 \\
\hline
\end{tabular}

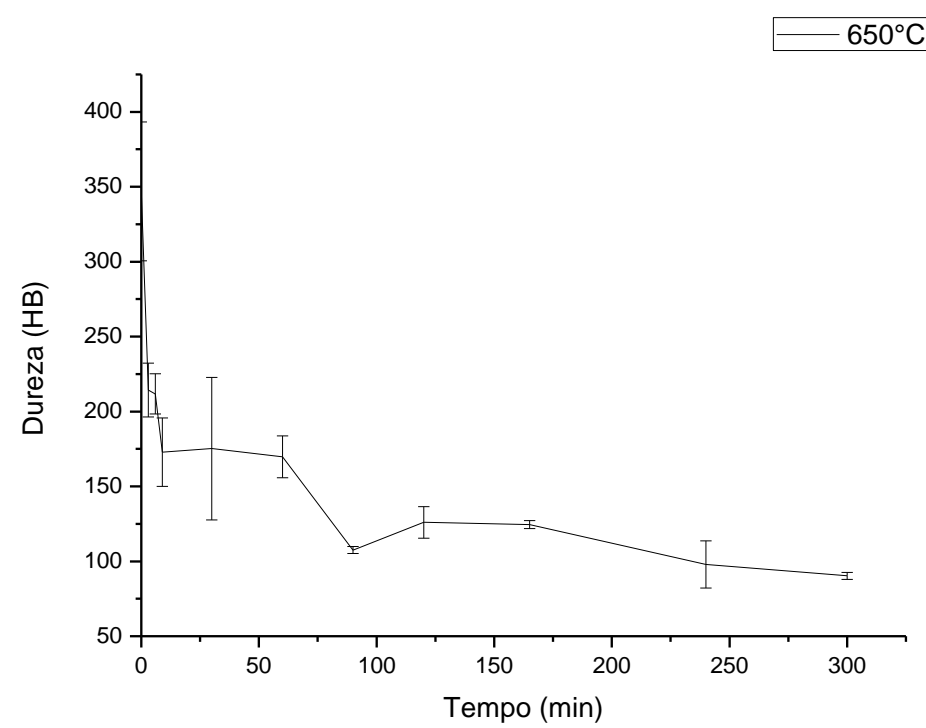

Figura 23- Dureza das amostras austenitizadas a $900{ }^{\circ} \mathrm{C}$ por uma hora e revenidas a $650{ }^{\circ} \mathrm{C}$ em diferentes tempos. 


\subsection{CONCLUSÕES}

- A grafitização secundária em ferro fundido cinzento em tratamentos de $900{ }^{\circ} \mathrm{C}$ temperados e revenidos a $650{ }^{\circ} \mathrm{C}$ ocorre após $5 \mathrm{~h}$.

- É possível estimar a dilatação linear do material usando diferentes técnicas: dilatometria e método de Arquimedes.

- Durante o aquecimento até a temperatura de tratamento isotérmico de amostras previamente solubilizadas e temperadas observou-se uma forte contração da amostra ao atingir temperaturas entre 400 e $500^{\circ} \mathrm{C}$. Tratamentos interrompidos por têmpera ao chegar nesta temperatura seguidos de difração de raios $x$ permitiram demonstrar que esta contração correspondeu à uma diminuição da fração de austenita de $12 \%$ para $8 \%$, ao passo que o teor de carbono em solução na austenita aumentou em $0,3 \%$.

- O número total de nódulos de grafita secundária criados pelo tratamento térmico foi relativamente pequeno, comparado com o que a literatura relata para ferros fundidos nodulares. Isto é explicado pelo menor teor de carbono, e de silício e pela maior competição entre precipitação do carbono sobre as lamelas eutéticas graças à sua maior quantidade de interfaces com a matriz. 


\section{MODIFICAÇÕES MICROESTRUTURAIS EM UM FERRO FUNDIDO BRANCO COM DISPERSÕES FINAS DE GRAFITA}

\subsection{Introdução teórica}

Uma das formas de otimizar as propriedades superficiais de componentes de ferro fundido sujeitos à interação metal/metal é resfriando rapidamente a superfície de forma a obter uma camada de ferro fundido branco na superfície [40]. No entanto, para diminuir o atrito é importante garantir a presença de grafita, que confere propriedades auto-lubrificantes ao material. Uma forma de obter uma distribuição refinada de partículas de grafita é inicialmente produzir uma estrutura ledeburítica extremamente refinada, por coquilhamento, e em seguida submetê-la a um tratamento de maleabilização, uma grafitização no estado sólido. Neste trabalho, amostras de ferro fundido cinzento produzido para a fundição de blocos de motores de combustão interna [12] foram solidificadas em coquilhas refrigeradas de forma a refinar ao máximo a estrutura ledeburítica e depois estudadas em relação a sua grafitização, com o objetivo de explorar possibilidades de modificação superficial de componentes de motores de combustão.

\subsubsection{Ferro maleável}

O ferro maleável foi amplamente utilizado pelos chineses no século 3 (evidências arqueológicas) para aumentar a tenacidade do ferro fundido. No ocidente foi descoberto no século 17 e foi muito utilizado no século 19 [41]. A técnica foi patenteada por Prince Rupert em 1670 e estudada sistematicamente por René Antoine Ferchault de Réaumur.

O ferro maleável é obtido a partir de tratamento térmico do ferro fundido branco (estrutura bruta de solidificação) onde se deseja que todo o carbono esteja combinado na forma de cementita. O ferro branco é obtido pelo resfriamento rápido, onde a formação da célula eutética metaestável inibe o crescimento de grafita durante a solidificação. O aparecimento da grafita na condição bruta de solidificação é condicionado à composição química e pela taxa de resfriamento [2]. 


\subsubsection{Maleabilização}

O tratamento térmico de maleabilização consiste na transformação parcial ou total do carbono combinado na cementita em grafita. O ferro fundido maleável pode ser denominado como maleável branco (ou europeu), e maleável de núcleo preto (ou americano); o presente trabalho estudará o ferro fundido maleável de núcleo preto, cuja denominação é originada pela formação de grafita no estado sólido durante o tratamento de maleabilização. A grafita no ferro maleável de núcleo preto sem adição de elementos de liga possui morfologia nodular quase perfeita, podendo esta ser alterada pela composição química ou pela temperatura de recozimento [42].

A solidificação do ferro fundido branco ocorre de acordo com o diagrama metaestável. A Figura 24, esquematiza a região do eutético no sistema estável e metaestável; o eutético estável é formado por austenita e grafita e o eutético metaestável por austenita e carbonetos. O ferro branco é formado a partir da aplicação de um super-resfriamento abaixo da temperatura do eutético metaestável (Figura 25). Do contrário poderá ocorrer a formação de ferro fundido mesclado. A tenacidade e dutilidade do ferro fundido branco são muito baixas, devido à formação de cementita proporcionado pela alta taxa de resfriamento descrito anteriormente. Por este motivo é necessário o tratamento de maleabilização para torná-lo mais dúctil, sem reduzir a resistência mecânica. Na maleabilização a cementita se decompõe em grafita e austenita, sendo que a grafita formada no recozimento possui morfologia parcialmente esférica, possibilitando certa ductilidade ao material, sem reduzir a sua resistência [25].

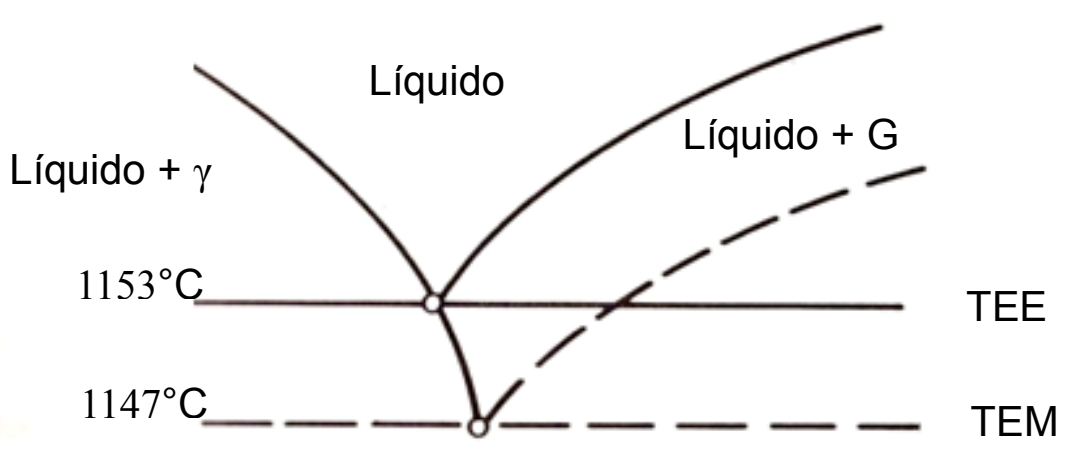

Figura 24 - Diagrama ferro carbono com a temperatura do eutético estável e metaestável [13]. 


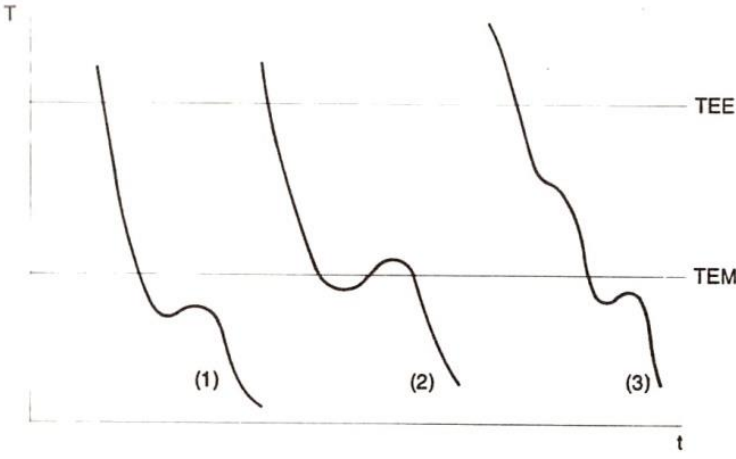

(1) Ferro Fundido Branco
(2) Ferro Fundido Mesclado (coquilhamento direto)
(3) Ferro Fundido Mesclado (coquilhamento inverso)

Figura 25 - Curva de resfriamento para os ferros fundidos brancos e mesclados [13].

O tratamento térmico de maleabilização branco pode ser dividido em três etapas: nucleação, primeiro estágio de grafitização (PEG) e segundo estágio de grafitização (SEG). A Figura 26 apresenta o ciclo típico de maleabilização de um ferro fundido sem elementos de liga. O primeiro trecho corresponde à etapa de nucleação de grafita, que ocorre durante o aquecimento e no início do tratamento isotérmico. $\mathrm{O}$ trecho II corresponde ao PEG e ocorre no campo do diagrama de fases, onde a austenita coexiste com carbonetos e grafita, na faixa de 900 e $960^{\circ} \mathrm{C}$ [42]. A reação no PEG é descrita por: $\mathrm{Fe}_{3} \mathrm{C} \rightarrow \gamma+\mathrm{C}$ (grafita) [2,43]. O trecho III corresponde ao SEG, acontece na faixa 700 a $750^{\circ} \mathrm{C}$ [42] e tem como objetivo a obtenção de matriz ferrítica [44]. A nucleação e crescimento de grafita se concentram nos trechos I e II e por isso a segunda etapa de grafitização não foi executada neste trabalho.

\subsubsection{Etapa de nucleação}

A nucleação de grafita poderá ocorrer durante a solidificação, a partir do líquido, tendo o seu crescimento inibido pelo crescimento do eutético metaestável ou no estado sólido durante tratamento térmico [2].

A grafita poderá encontrar locais propícios para nucleação como: sulfetos de manganês ou de ferro, interfaces austenita/cementita, austenita primária/carboneto eutético e austenita eutética/carboneto [44]. Guesser e Kuhl [2], adicionam partículas de nitretos e sulfetos como possíveis locais de nucleação. 


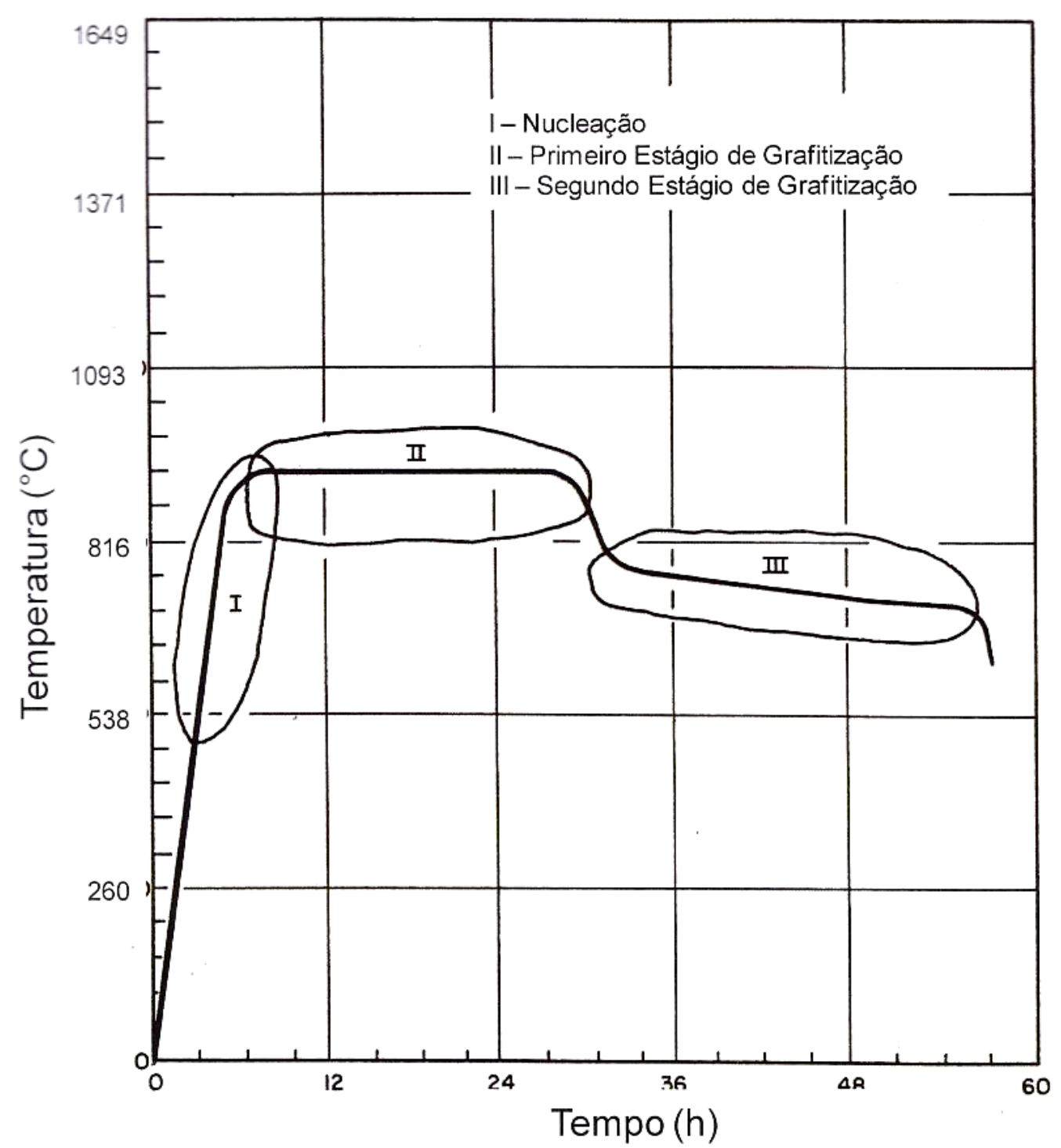

Figura 26 - Curva de maleabilização típica [44].

Guesser e Pieske [45], estudando a nucleação de grafita no recozimento em ferro fundido maleável, observaram a nucleação na interface austenita/cementita eutética. Eles construíram um modelo na forma de um desenho esquemático (Figura 27) demonstrando a nucleação e crescimento de grafita no PEG na interface austenita/cementita eutética, baseado em observações por microscopia ótica. A Figura 27a corresponde a cementita (1), perlita (antiga austenita) (2), ferrita e (3), cementita; a cementita da perlita esferoidiza durante o tratamento de maleabilização (Figura 27b e c), resultando no surgimento de áreas de ferrita. A grafita nucleia e cresce na interface austenita/cementita eutética (Figura 27d). A grafita cresce a partir da dissolução da cementita eutética (Figura 27e). O contato entre as partículas de 
grafita e a cementita é interrompido (Figura 27f) e a cementita esferoidizada passa a se dissolver ao redor destas partículas. A cementita é completamente dissolvida resultando em uma matriz ferrítica com nódulos de grafita (Figura 27g) [2].

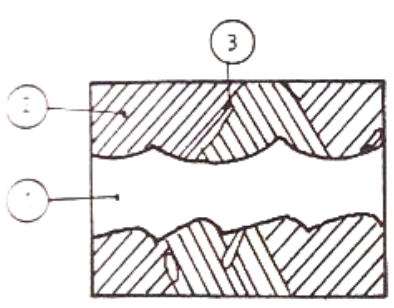

(a)

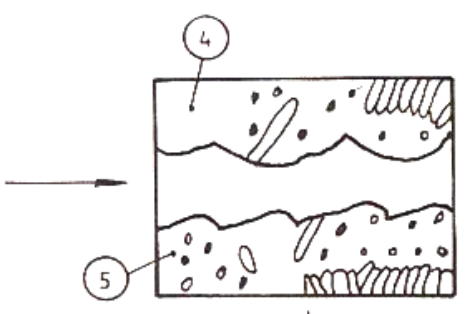

(b)

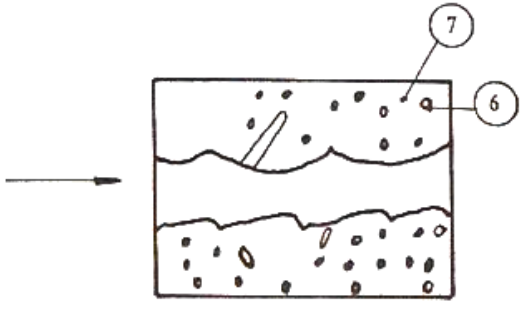

[C)

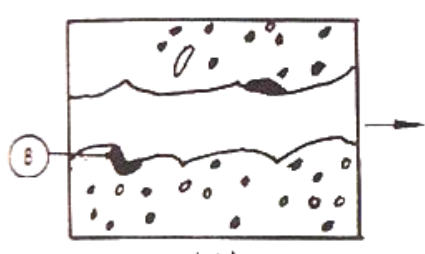

(d)

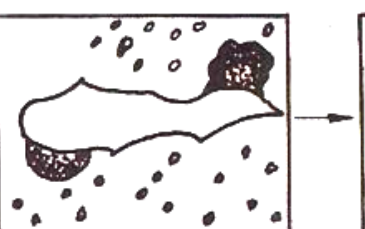

(e)

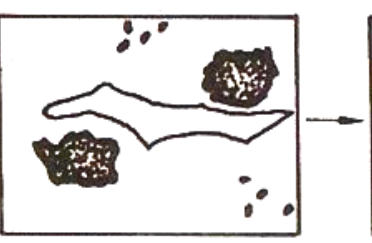

(f)

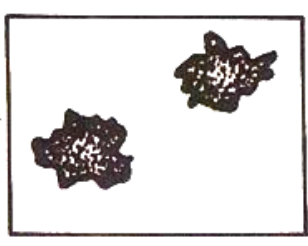

191

Figura 27 -Desenho esquemático demonstrando a nucleação de grafita na interface austenita/cementita eutética [2].

Outra alternativa para aumentar a taxa de nucleação de grafita é aumentar a concentração de C e Si. Rouns e Rundman [46], em tratamentos de envelhecimento a $550{ }^{\circ} \mathrm{C}$ em ferro fundido nodular, observaram que a medida que o teor de Si na liga é aumentado, o tamanho das partículas de grafita diminui e a quantidade de nódulos aumenta, como mostra a Figura 28.

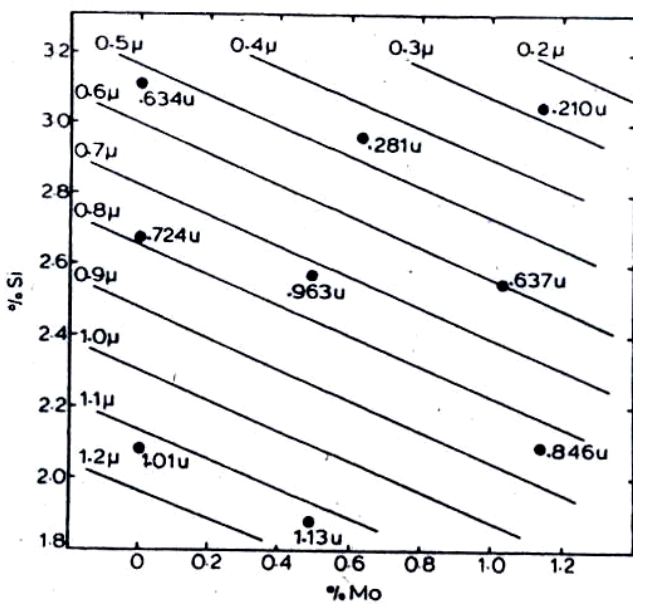

(a)

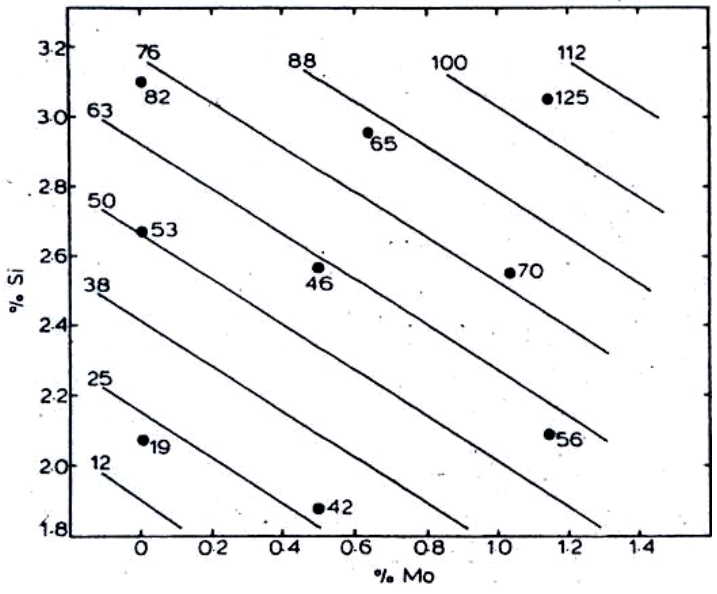

(b)

Figura 28- Efeito dos elementos Si e Mo na grafitização secundária. a) no tamanho da grafita secundária. b) na quantidade de grafita secundária [28]. 


\subsubsection{Cinética do primeiro estágio de grafitização}

A cinética de grafitização da transformação da cementita em grafita é um parâmetro muito importante em processos industriais. A partir da curva de cinética é possível fazer a previsão da formação de grafita e especificar o processamento.

Burke e Swindells [38] estudaram a nucleação e o crescimento de grafita durante o tratamento de maleabilização, onde a cinética foi acompanhada através da medida da variação do comprimento a partir de amostras de Fe-C-Si variando a composição química de carbono $(2$ a 3,5) e Si $(0,68$ a 1,37). A metodologia experimental utilizada foi a variação da temperatura em tratamentos isotérmicos. $A$ cinética foi estudada a partir da equação 29 obtida por Burke e Swindells, semelhante à equação JMAK.

$$
y=1-\exp \left((-K \cdot t)^{n}\right)
$$

A equação 30 é a equação linearizada da equação 29 , utilizada para analisar medidas de cinéticas experimentais. Onde y corresponde a fração transformada aparente tendendo ao equilíbrio, ou seja, pode não representar a transformação $100 \%$.

$$
\ln \left(\ln \frac{1}{1-\mathrm{y}}\right)=\mathrm{n} \cdot \ln (\mathrm{k})+\mathrm{n} \cdot \ln (\mathrm{t})
$$

\subsubsection{Modelo de crescimento da grafita}

O tratamento de maleabilização no primeiro estágio de grafitização consiste na formação de grafita a partir da difusão de carbono ou pela dissolução de cementita. A cementita é uma fase metaestável, ou seja, o carbono na austenita em equilíbrio com a cementita na temperatura de maleabilização apresenta-se em maior concentração do que o carbono na austenita em equilíbrio com a grafita [2]. Essa diferença de concentração de carbono na austenita provoca a movimentação de átomos de carbono em direção à grafita provocando o crescimento da grafita e dissolução da cementita.

Os processos que governam a taxa de crescimento são [47]: 
- Teor de carbono na austenita em equilíbrio com a grafita e cementita;

- Difusão de carbono através da austenita;

- Precipitação de carbono na grafita;

- Remoção de átomos de ferro ou átomos substitucionais da frente da curva de crescimento para movimentar a interface;

Vários autores acreditam que a taxa de crescimento da grafita esteja correlacionada à difusão de carbono. Assume-se que a difusão de carbono é relativamente alta a ponto de manter a concentração de carbono da interface de cementita e grafita com seus valores de equilíbrio.

Uma forma de determinação do mecanismo de crescimento da grafita é a análise do valor k obtido na equação 30. Brown et al., Ferry et al., Birchenal apud Burke [38] obtiveram em seus valores experimentais valores de $\mathrm{k}$ próximos a 2,5 e concluíram que a taxa de crescimento de grafita estava associada à difusão de carbono. A curva de crescimento foi associada a uma parábola.

O valor aproximado de $n$ obtido por Burke foi igual a 4 e alguns autores atribuem valor de $\mathrm{n}$ igual a 4 a uma taxa de nucleação constante $[39,48]$. No entanto, como mencionado anteriormente, a taxa de crescimento de nódulos de grafita pode ser associada à difusão de carbono apenas para valor de $n$ igual a 2,5; dessa forma Burke concluiu que em seus experimentos a taxa de grafitização não foi controlada por difusão.

Hillert apud Burke [38] concluiu que os vazios criados pela deformação da austenita no primeiro estágio de grafitização são importantes apenas nos primeiros estágios de nucleação, e que em seguida a taxa de crescimento é controlada pela deformação da matriz.

Segundo Burke valores de n próximos a 4 são encontrados para ferro fundido branco de alta pureza; valores de $\mathrm{n}$ entre 2 e 3 para ferros brancos comerciais. Em um ferro de alta pureza quem controla a taxa de crescimento é a dissolução do carboneto e para ferros brancos comerciais quem controla a taxa de crescimento é a difusão de carbono [38]. 


\subsection{MATERIAIS E MÉTODOS}

A metodologia utilizada nas amostras de ferro branco é representada no fluxograma a seguir:

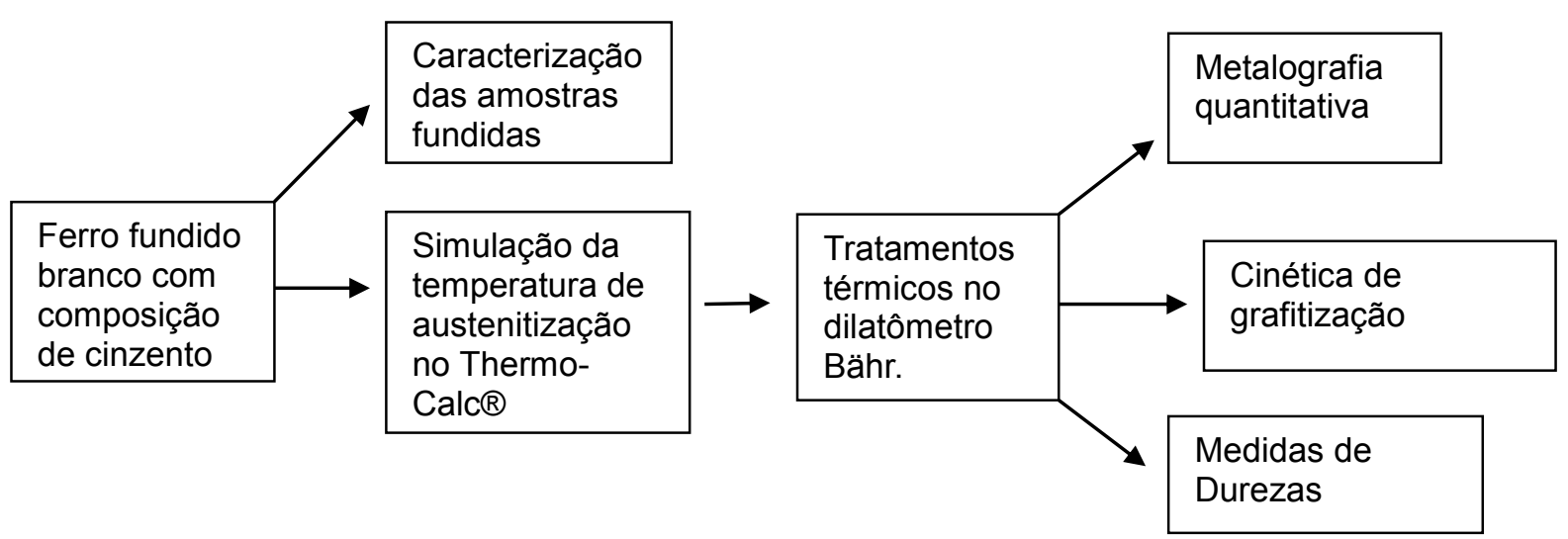

Amostras coquilhadas foram fabricadas a partir da fusão a $1500^{\circ} \mathrm{C}$ em um forno de indução de uma liga com composição de um ferro fundido cinzento comercial pela TUPY S.A. O ferro líquido foi resfriado rapidamente em uma coquilha de cobre refrigerada a água, submetendo o material a uma alta taxa de resfriamento, transformando-o em ferro branco com composição química de um ferro fundido cinzento (FBC). A composição química do material estudado apresenta-se na Tabela 6.

Tabela 6 - Composição química do ferro fundido branco produzido na TUPY S.A.

\begin{tabular}{|c|c|c|c|c|c|c|}
\hline $\mathbf{C}$ & $\mathbf{S i}$ & $\mathbf{P}$ & $\mathbf{S}$ & $\mathbf{C r}$ & $\mathbf{C u}$ & $\mathbf{M n}$ \\
\hline 3,26 & 2,08 & 0,037 & 0,102 & 0,28 & 0,502 & 0,89 \\
\hline
\end{tabular}

O ferro fundido branco assim obtido difere do utilizado nos trabalhos clássicos citados na revisão bibliográfica por ter a composição de um ferro fundido cinzento convencional e por ter sido coquilhado sob uma taxa de retirada de calor muito mais intensa, o que se reflete na obtenção de uma ledeburita mais refinada.

As amostras na condição bruta de solidificação foram caracterizadas por análise metalográfica e imagens foram obtidas por microscopia óptica (MO) e eletrônica de varredura (MEV). As propriedades mecânicas foram analisadas por medidas de microdureza Vickers, usando uma carga de $300 \mathrm{~g}$.

A temperatura de austenitização foi estimada pelo software Thermo-Calc®, a 
partir da composição química apresentada na Tabela 6. A temperatura utilizada para os tratamentos de austenitização foi $900{ }^{\circ} \mathrm{C}$, onde as fases em equilíbrio são respectivamente: austenita (1_FCC_A1) e grafita (2_graphite) como pode ser verificado na Figura 29.

A partir da concentração em peso da composição em equilíbrio da austenita (FCC_A1) calculada usando Thermo-Calc® para a temperatura de $900{ }^{\circ} \mathrm{C}$ (Tabela 7), o Ms estimado pela equação empírica de Andrews (Equação 8) foi igual a $120{ }^{\circ} \mathrm{C}$.

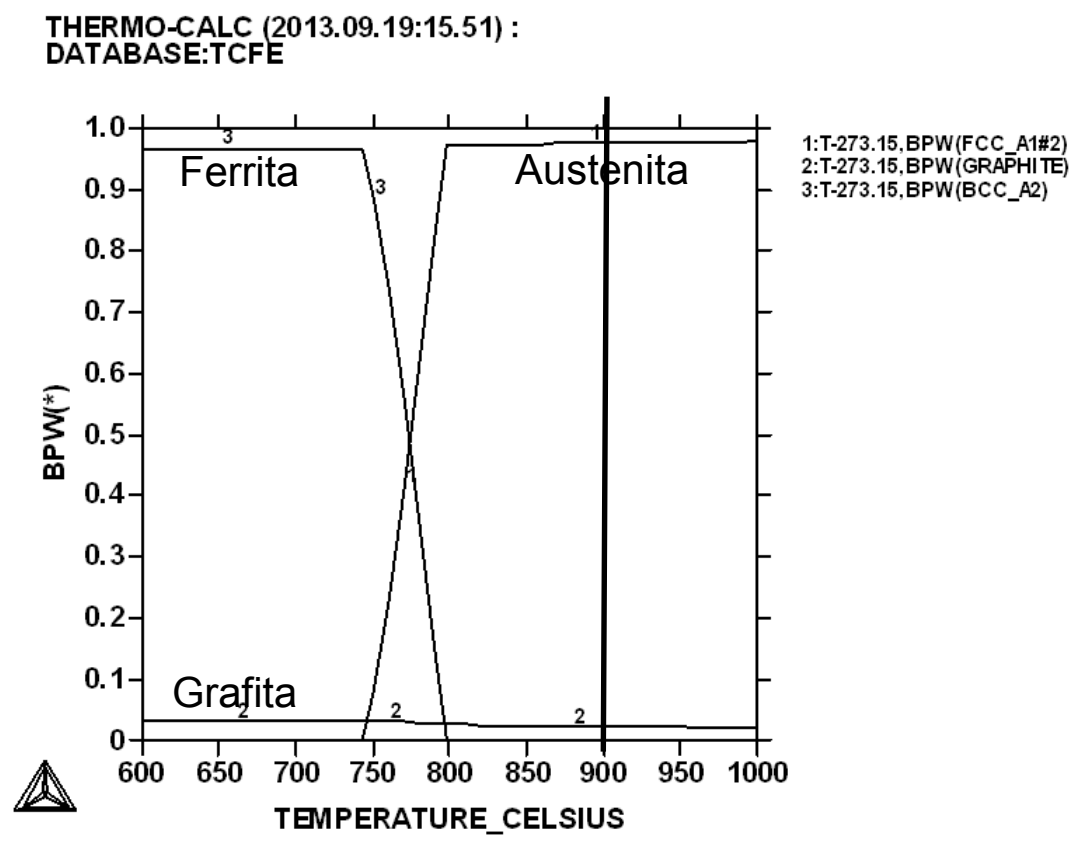

Figura 29 - simulação das fases em equilíbrio em função da temperatura estimadas no software Thermo-Calc® de um ferro fundido branco.

Tabela 7 - Simulação em Thermo-Calc® da composição química da austenita em equilíbrio a $900{ }^{\circ} \mathrm{C}$ de um ferro fundido branco.

\begin{tabular}{|c|c|c|c|c|c|c|}
\hline $\mathbf{C}$ & $\mathbf{S i}$ & $\mathbf{P}$ & $\mathbf{S}$ & $\mathbf{C r}$ & $\mathbf{C u}$ & $\mathbf{M n}$ \\
\hline 0,879 & 2,131 & $3,791.10^{-4}$ & 0,102 & 0,28 & 0,5 & 0,912 \\
\hline
\end{tabular}

Os ensaios de dilatometria foram efetuados para a determinação da cinética de reações durante o PEG. Por sua vez, a caracterização metalográfica e medidas de durezas foi utilizada para determinação da melhor condição a ser ensaiada no teste de desgaste por deslizamento, resultados apresentados no capítulo 5. A partir das "bolachinhas" coquilhadas na condição bruta de solidificação foram usinados corpos 
cilíndricos com $4 \mathrm{~mm}$ de diâmetro por $10 \mathrm{~mm}$ de comprimento. O ciclo térmico utilizado nos ensaios de dilatometria é mostrado na Figura 30; as amostras foram aquecidas até a temperatura de austenitização de $900{ }^{\circ} \mathrm{C}$ a uma taxa de $20{ }^{\circ} \mathrm{C} / \mathrm{s}$ e mantidas nesta temperatura sob diferentes tempos de tratamento $(3,5,7,10,30$ e $60 \mathrm{~min}$.). Subsequentemente, foram resfriadas com gás He a uma taxa de $100^{\circ} \mathrm{C} / \mathrm{s}$ até $25^{\circ} \mathrm{C}$. A seguir, as amostras foram reaquecidas a $200{ }^{\circ} \mathrm{C}$ e mantidas nesta temperatura durante 30 min e novamente resfriadas à temperatura ambiente a uma taxa de 100 ${ }^{\circ} \mathrm{C} / \mathrm{s}$. Para cada ensaio foram utilizadas pelo menos duas amostras. As identificações das amostras ensaiadas nos ensaios de dilatometria seguem descritos na Tabela 8. No geral o FBC pós-tratamento térmico será identificado como FBM (ferro branco modificado).

Tabela 8 - Identificação das amostras de ferro fundido branco

\begin{tabular}{|c|c|}
\hline Nomenclatura & Tratamentos térmicos efetuados \\
\hline CR & Amostra na condição como recebida - bruta de solidificação \\
\hline $900-3$ & $\begin{array}{l}\text { Amostra austenitizada, a uma taxa de aquecimento de } 20{ }^{\circ} \mathrm{C} / \mathrm{s} \text {, a } 900{ }^{\circ} \mathrm{C} \\
\text { durante } 3 \text { min , resfriada até } 25^{\circ} \mathrm{C} \text { a uma taxa de } 100^{\circ} \mathrm{C} \text { e revenida a } 200 \\
{ }^{\circ} \mathrm{C} \text { durante } 30 \mathrm{~min} \text {. }\end{array}$ \\
\hline $900-5$ & $\begin{array}{l}\text { Amostra austenitizada, a uma taxa de aquecimento de } 20^{\circ} \mathrm{C} / \mathrm{s} \text {, a } 900{ }^{\circ} \mathrm{C} \\
\text { durante } 5 \mathrm{~min} \text {, resfriada até } 25^{\circ} \mathrm{C} \text { a uma taxa de } 100^{\circ} \mathrm{C} \text { e revenida a } 200 \\
{ }^{\circ} \mathrm{C} \text { durante } 30 \mathrm{~min} \text {. }\end{array}$ \\
\hline $900-7$ & $\begin{array}{l}\text { Amostra austenitizada, a uma taxa de aquecimento de } 20^{\circ} \mathrm{C} / \mathrm{s} \text {, a } 900{ }^{\circ} \mathrm{C} \\
\text { durante } 7 \mathrm{~min} \text {, resfriada até } 25^{\circ} \mathrm{C} \text { a uma taxa de } 100^{\circ} \mathrm{C} \text { e revenida a } 200 \\
{ }^{\circ} \mathrm{C} \text { durante } 30 \mathrm{~min} \text {. }\end{array}$ \\
\hline $900-10$ & $\begin{array}{l}\text { Amostra austenitizada, a uma taxa de aquecimento de } 20^{\circ} \mathrm{C} / \mathrm{s} \text {, a } 900{ }^{\circ} \mathrm{C} \\
\text { durante } 10 \mathrm{~min} \text {, resfriada até } 25^{\circ} \mathrm{C} \text { a uma taxa de } 100^{\circ} \mathrm{C} \text { e revenida a } \\
200^{\circ} \mathrm{C} \text { durante } 30 \mathrm{~min} \text {. }\end{array}$ \\
\hline $900-30$ & $\begin{array}{l}\text { Amostra austenitizada, a uma taxa de aquecimento de } 20{ }^{\circ} \mathrm{C} / \mathrm{s} \text {, a } 900{ }^{\circ} \mathrm{C} \\
\text { durante } 30 \text { min , resfriada até } 25^{\circ} \mathrm{C} \text { a uma taxa de } 100^{\circ} \mathrm{C} \text { e revenida a } \\
200^{\circ} \mathrm{C} \text { durante } 30 \text { min. }\end{array}$ \\
\hline $900-60$ & $\begin{array}{l}\text { Amostra austenitizada, a uma taxa de aquecimento de } 20^{\circ} \mathrm{C} / \mathrm{s} \text {, a } 900{ }^{\circ} \mathrm{C} \\
\text { durante } 60 \text { min , resfriada até } 25^{\circ} \mathrm{C} \text { a uma taxa de } 100^{\circ} \mathrm{C} \text { e revenida a } \\
200{ }^{\circ} \mathrm{C} \text { durante } 30 \mathrm{~min} \text {. }\end{array}$ \\
\hline
\end{tabular}

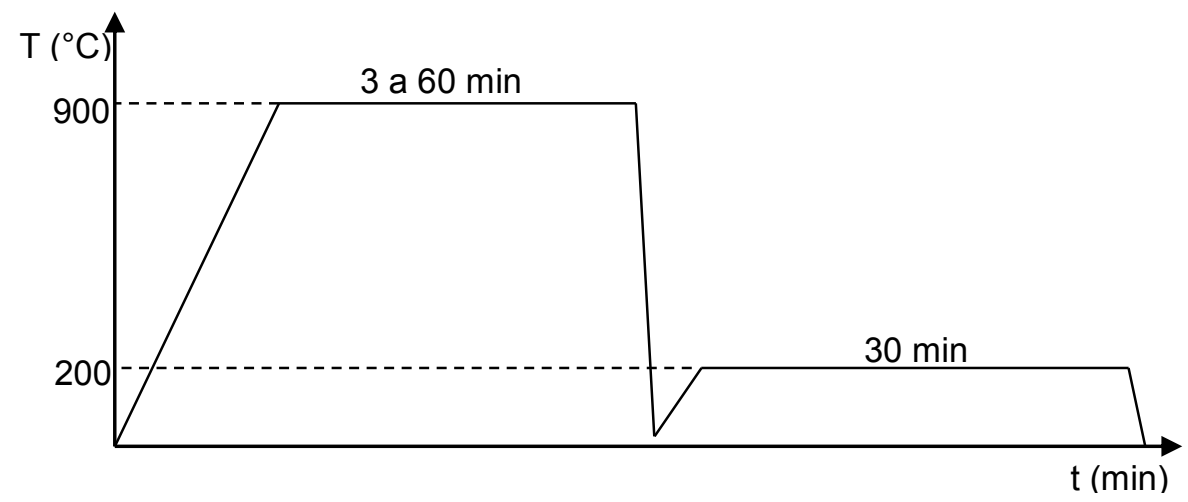

Figura 30 - Ciclo térmico das amostras submetidas nos testes de dilatometria a partir de amostras de ferro fundido branco na condição bruta de solidificação. 
Os resultados obtidos foram usados para a determinação do início e fim das transformações, determinação da dilatação total do material nos tratamentos isotérmicos, e para obter os parâmetros $\mathrm{n}$ e $\mathrm{k}$ da equação empírica de Burke [38] semelhante a JMAK.

As amostras foram embutidas e analisadas metalograficamente. As imagens obtidas por MEV sem ataque utilizando elétrons retroespalhados foram usadas para quantificar as grafitas formadas durante os tratamentos e analisadas pelo software ImageJ. O reagente químico Nital 2\%, foi usado para analisar as microestruturas formadas durante os tratamentos térmicos. Em todas as amostras foram feitas medidas de microdureza HV0,3 para avaliar as propriedades mecânicas das amostras tratadas. 


\subsection{RESULTADOS E DISCUSSÃO}

\subsubsection{Caracterização microestrutural da amostra de ferro fundido branco na condição bruta de solidificação}

Apesar do coquilhamento, não foi possível evitar a formação de grafita primária na solidificação, como pode ser verificado na amostra sem ataque (Figura 31), além de grafita verifica-se a presença de sulfeto de manganês.

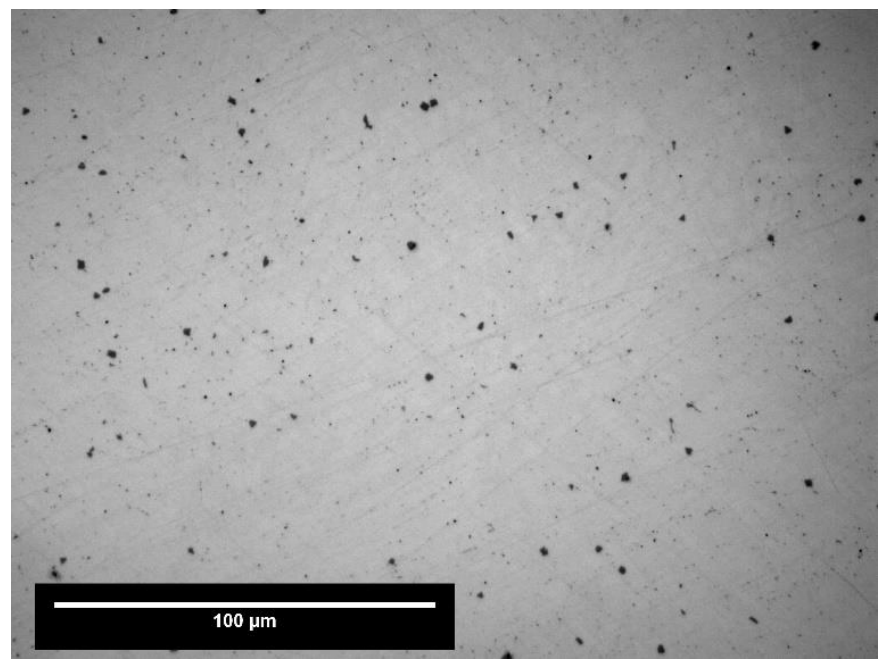

Figura 31 - Microestrutura sem ataque da amostra na condição bruta de solidificação, mostrando a presença de nódulos de grafita.

O material de partida apresenta microestrutura semelhante a de um came coquilhado descrito na referencia [40]. Na Figura 32a observa-se a microestrutura da superfície do material em estudo enquanto na Figura 32b observa-se a microestrutura do came coquilhado. Os dois materiais também apresentam durezas similares, a dureza do FBC é de $600 \mathrm{HV}$ e a do came coquilhado variou entre $750-550 \mathrm{HV}$. A distância média entre braços dendríticos foi comparada com trabalhos utilizando diferentes técnicas de refusão de superfície. A distância média entre placas de cementita da ledeburita foi $2 \mu \mathrm{m}$, comparando com um ferro fundido de composição química similar usando refusão a laser foi 0,6 $\mu \mathrm{m}$ [11], e um came de comando de válvulas automotivo como superfície refundida usando TIG (eletrodo de Tungstênio com gás inerte) exibiu distâncias de $6 \mu \mathrm{m}$ [40]. A proposta de obtenção de células eutéticas refinadas segue o raciocínio proposto por Burke [38]: tratamentos térmicos que refinam a estrutura eutética, assim como o superaquecimento, superresfriamento, e recozimento abaixo da zona crítica aumentam a quantidade de 
nódulos de grafita. Enfim, a partir dos resultados apresentados anteriormente concluise que o material na condição bruta de solidificação apresenta características superficiais semelhantes a de um came coquilhado.

A microestrutura do FBC é composta por carboneto de ferro (cementita),

(a)

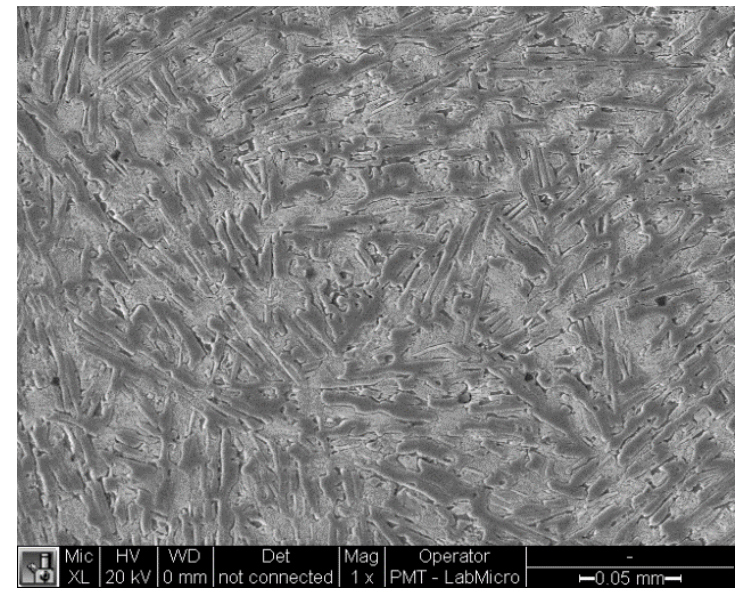

(b)

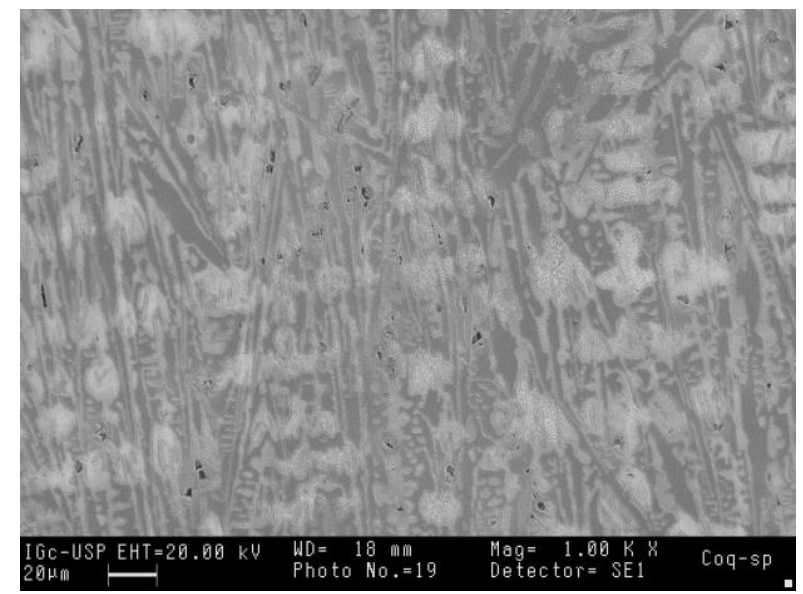

Figura 32 - comparativo entre microestruturas obtidas por coquilhamento atacadas com Nital $2 \%$.

(a) amostra de ferro branco com composição de ferro fundido cinzento; (b) amostra de um came coquilhado descrito na referência [40].

alguma grafita primária e perlita, como pode ser visualizado nas micrografias obtidas por MO (Figura 33). Com maiores aumentos é possível identificar a perlita formada a partir da austenita eutética (Figura 32a).
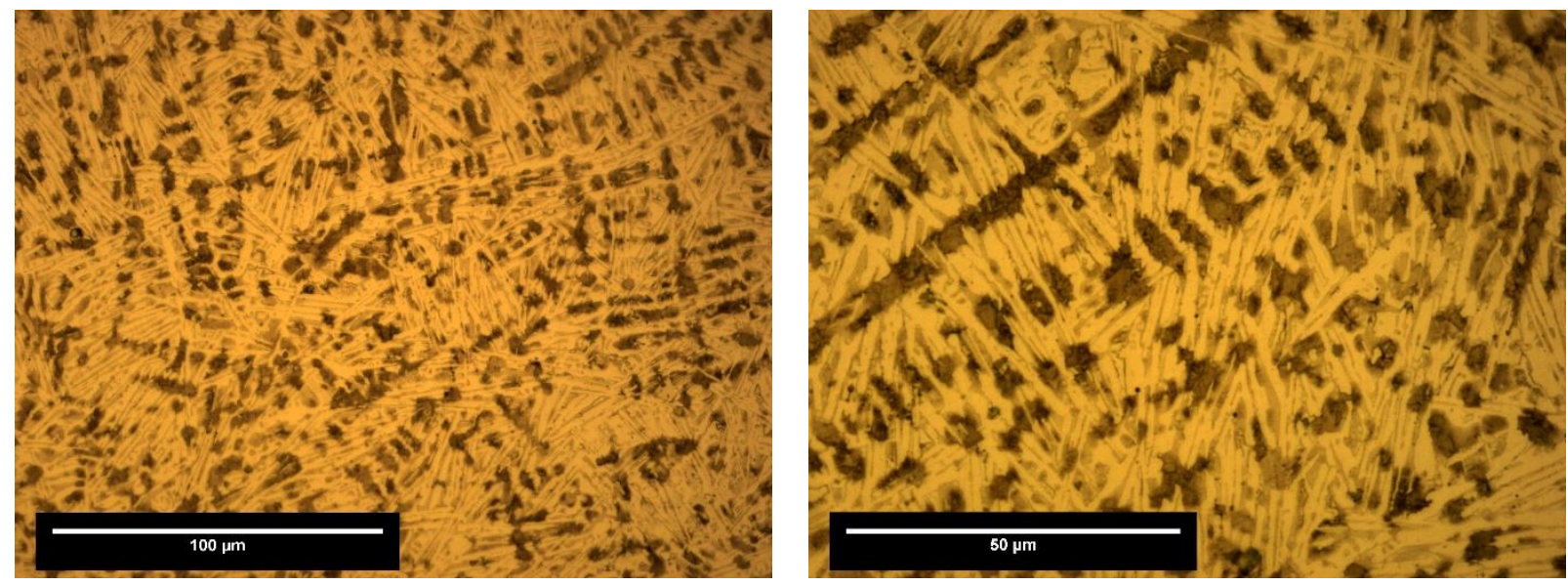

Figura 33 - Ferro branco coquilhado com composição química de ferro cinzento. (a) 500 X; (b) 1000 X. Atacadas com Nital $2 \%$.

\subsubsection{AMOSTRAS COMO RECEBIDAS SUBMETIDAS A TRATAMENTOS TÉRMICOS}

O refinamento da cementita proporcionado pela coquilha de cobre se mostrou 
eficiente na nucleação de grafita, devido ao aumento de área interfacial disponível para a nucleação de grafita [49]. A ideia de refinar a cementita, seguindo o modelo de crescimento de grafita pela dissolução de cementita segue o raciocínio proposto na teoria [49] , em que diminuindo a distância de difusão de carbono na austenita, o crescimento de grafita será acelerado.

Em tempos relativamente curtos de tratamento térmico de austenitização a 900 ${ }^{\circ} \mathrm{C}$ percebe-se a formação de grafita a partir da dissolução de cementita, como mostra a Figura 34a. Esta amostra foi tratada a $900^{\circ} \mathrm{C}$ durante 3 minutos temperada usando gás He a uma taxa de $100{ }^{\circ} \mathrm{C} / \mathrm{s}$ e reaquecidas a $200^{\circ} \mathrm{C}$ durante 30 minutos. A grafita formada após tratamentos térmicos não é perfeitamente esférica (Figura 34b), não foi introduzido Fe-Si-Mg. A microestrutura observada para este tratamento térmico foi matriz de martensita revenida, perlita, grafita e cementita.
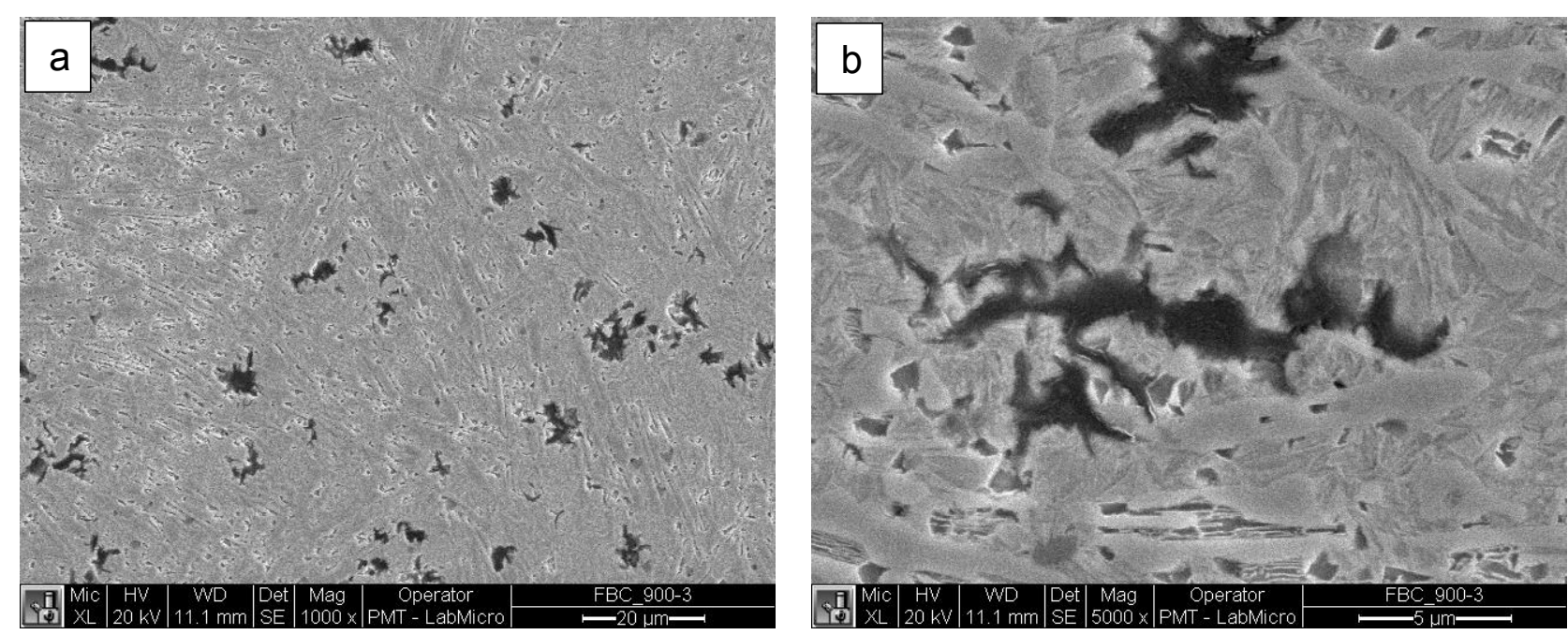

Figura 34 - Ferro branco tratado a $900{ }^{\circ} \mathrm{C}$ durante 3 min e revenido a $250{ }^{\circ} \mathrm{C}$ durante $30 \mathrm{~min}$. MEV usando elétrons secundários atacados com Nital $2 \%$.

A distribuição da grafita secundária no PEG confirma a interpretação de Guesser [2]: o crescimento da grafita segue dois mecanismos: difusão do carbono e dissolução do carboneto eutético (cementita). A presença de cementita e a matriz de martensita revenida podem ser observadas na Figura 35. Percebe-se nesta figura que a grafita encontra-se próxima à cementita que serve como fonte de carbono para o seu crescimento. 


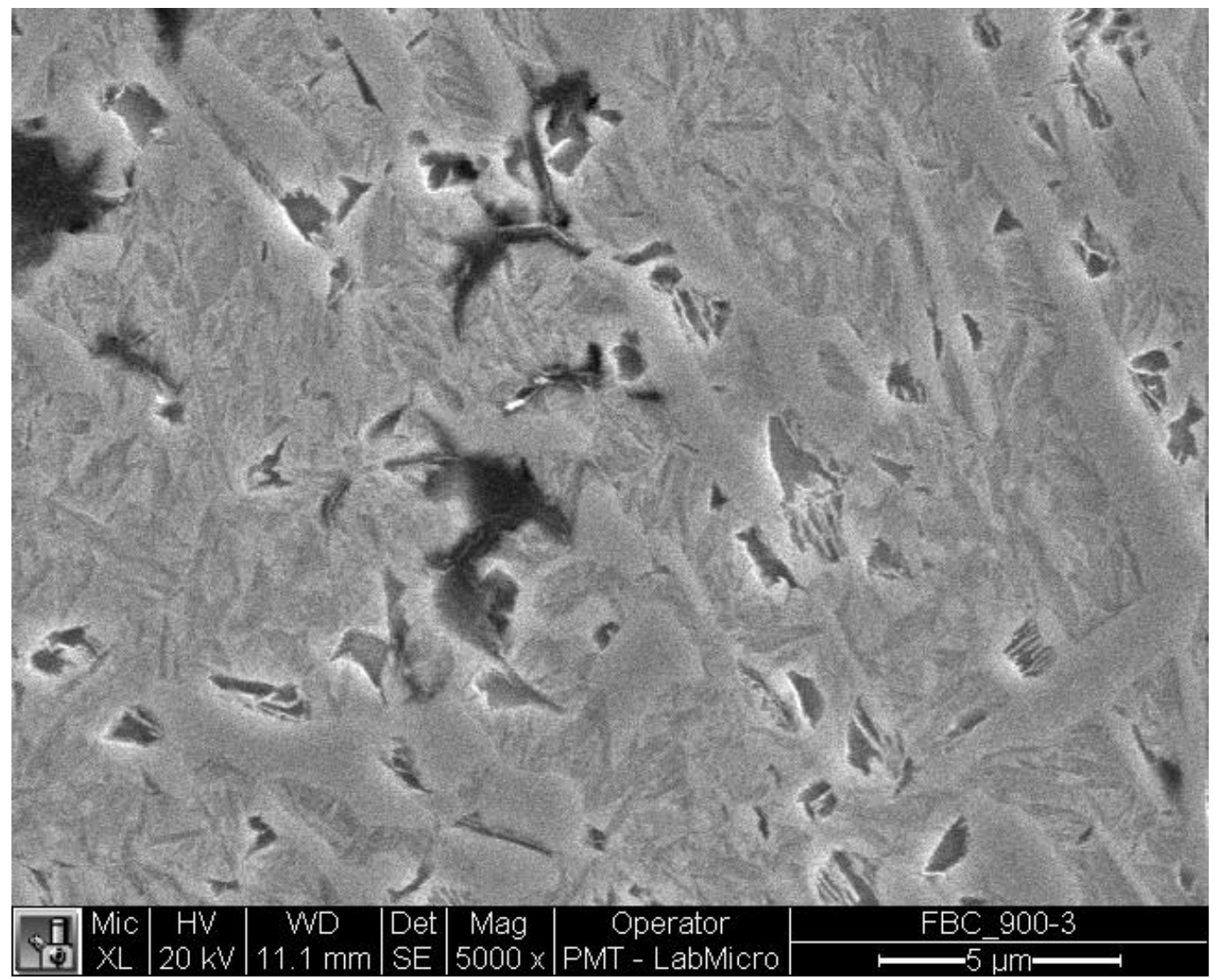

Figura 35 - FBC 900-3. Crescimento de grafita a partir da cementita.

$\mathrm{Na}$ amostra 900-15 (Figura 36) foi feito um ataque profundo da matriz, usando Nital $2 \%$, durante 2 minutos. A grafita, cementita e austenita ficaram em alto-relevo, percebe-se que a cementita está com os cantos arredondados e a presença de austenita retida na matriz de martensita revenida.
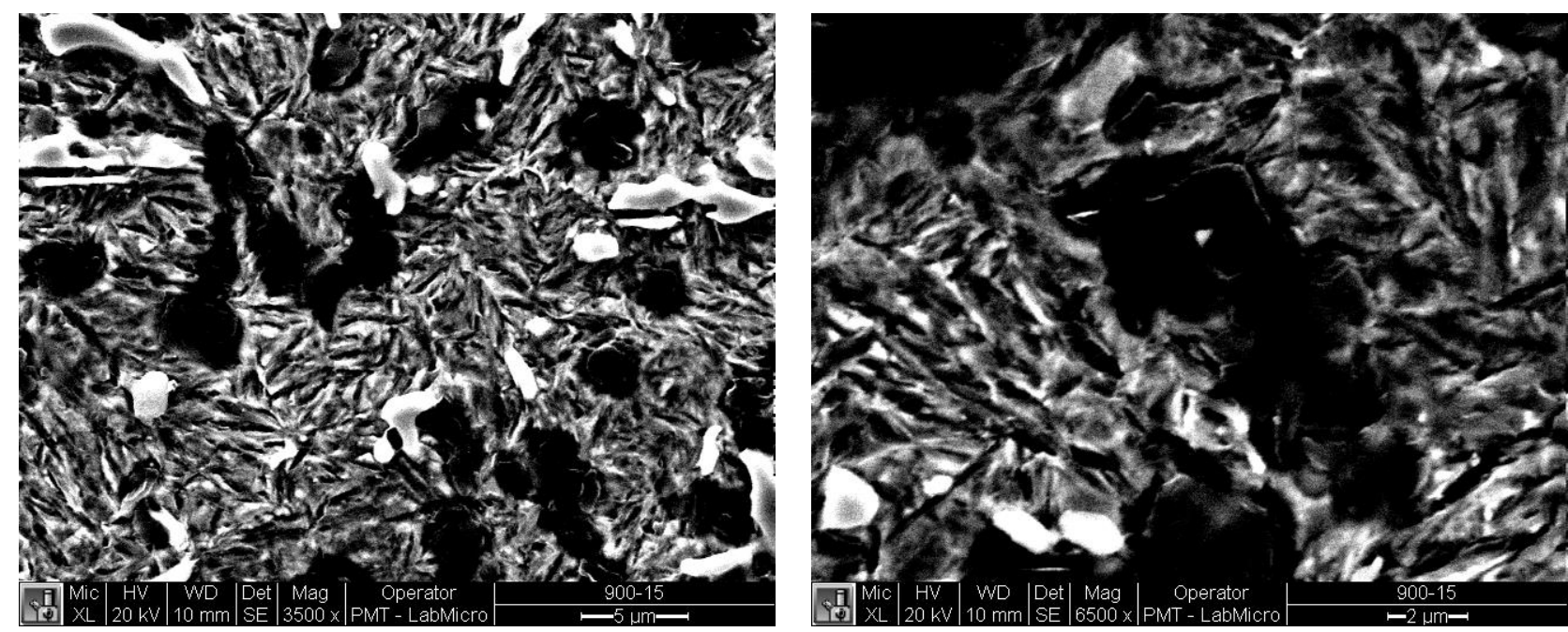

Figura 36 - Ataque profundo da matriz usando Nital 2\% (900-15)

A evolução da microestrutura no tratamento a $900{ }^{\circ} \mathrm{C}$ em função do tempo, 
seguido de reaquecimento a $200{ }^{\circ} \mathrm{C}$ durante 30 minutos pode ser acompanhada na Figura 37, onde percebe-se a diminuição da quantidade de cementita e o aumento dos nódulos de grafita (quantidade e tamanho), ou seja, a grafita sendo formada ou aumentando de tamanho às custas da dissolução de cementita. Após quinze minutos de tratamento térmico de austenitização grande parte da cementita foi dissolvida, como pode ser observado na Figura $37 \mathrm{c}$, sendo quase totalmente dissolvida em tempos de tratamentos maiores que 30 minutos.

Após a completa solubilização da cementita, a grafita atinge o ponto de maior crescimento de nódulos (ponto de saturação do crescimento de grafita). Isto também foi observado por outros autores que estudaram a cinética de grafitização, porém a medida era feita a partir do maior nódulo visível. Burke correlaciona a solubilidade da cementita à cinética de grafitização [49].

(a)

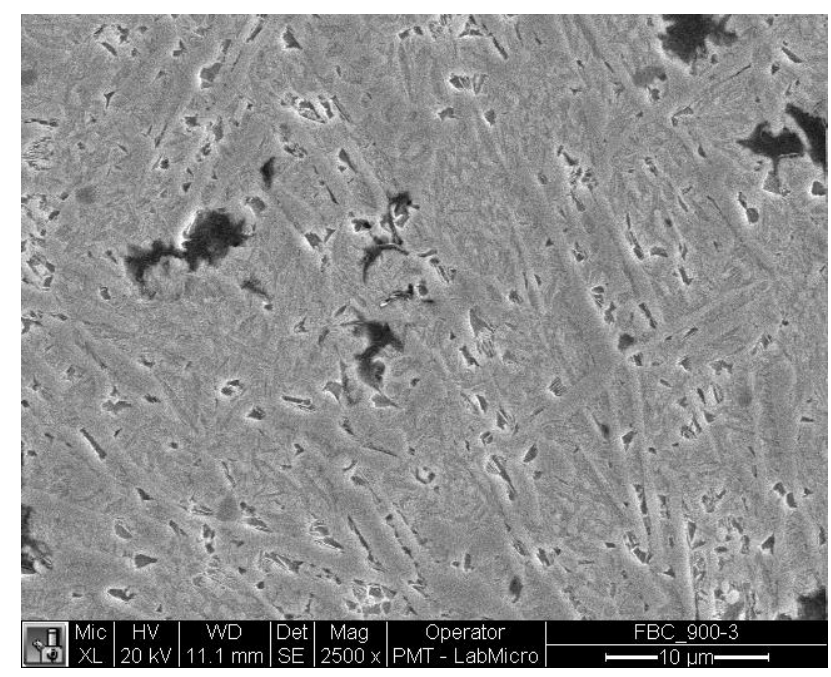

(c)

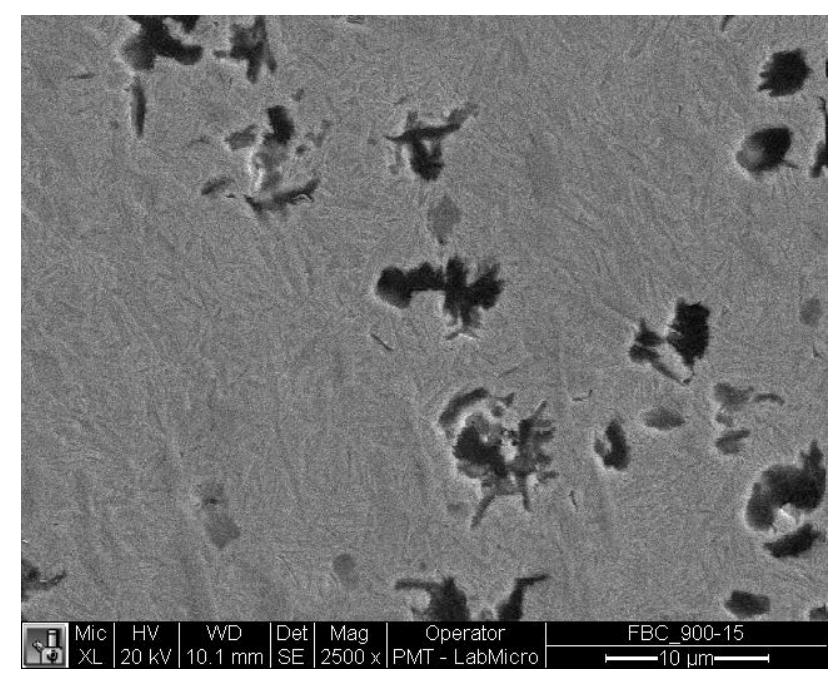

(b)

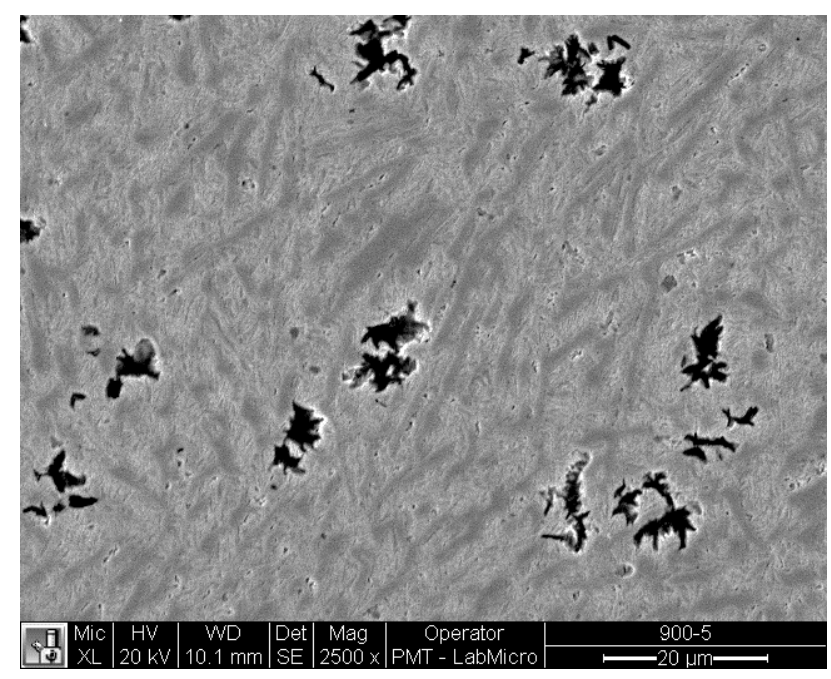

(d)

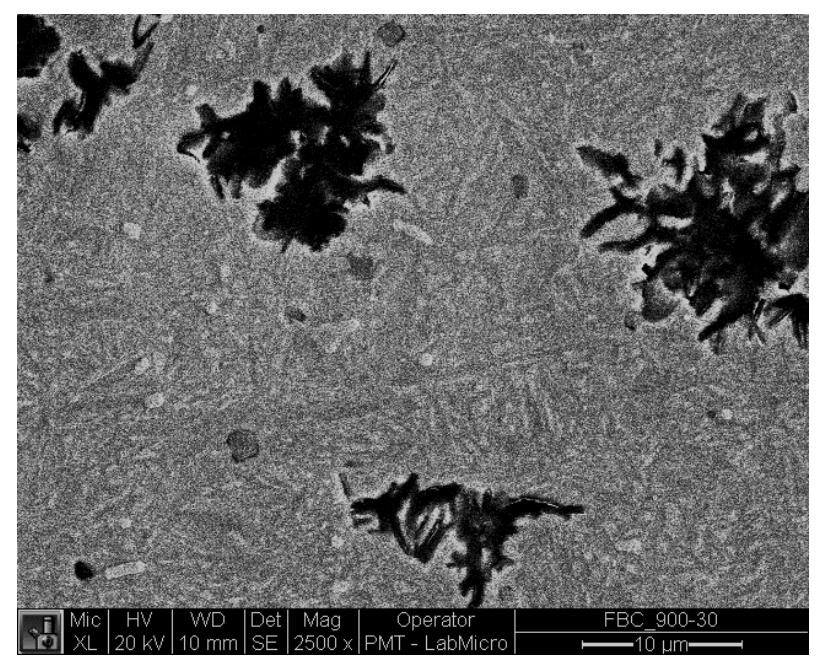

Figura 37 - MEV de amostras FBM. (a) 900-5; (b) 900-10; (c) 900-15; (d) 900-30. 
O aumento dos nódulos e a evolução dos nódulos de grafita, também podem ser acompanhados na Figura 38, que mostra resultados obtidos usando metalografia quantitativa via analisador de imagens (a metodologia empregada pode ser acompanhada nos anexos $\mathrm{C}$ e D). O tempo de tratamento térmico influencia na $\mathrm{Vv}$ e no tamanho médio da grafita. Os dois aumentam na medida em que o tempo de austenitização aumenta. Após trinta minutos de manutenção a $900{ }^{\circ} \mathrm{C}$, tanto o tamanho do diâmetro médio quanto a fração volumétrica tendem a um valor constante. A justificativa para este fenômeno é que, como a cementita próxima aos nódulos de grafita foi totalmente dissolvida (Figura 37), a grafita só vai aumentar de tamanho com o carbono proveniente da matriz.

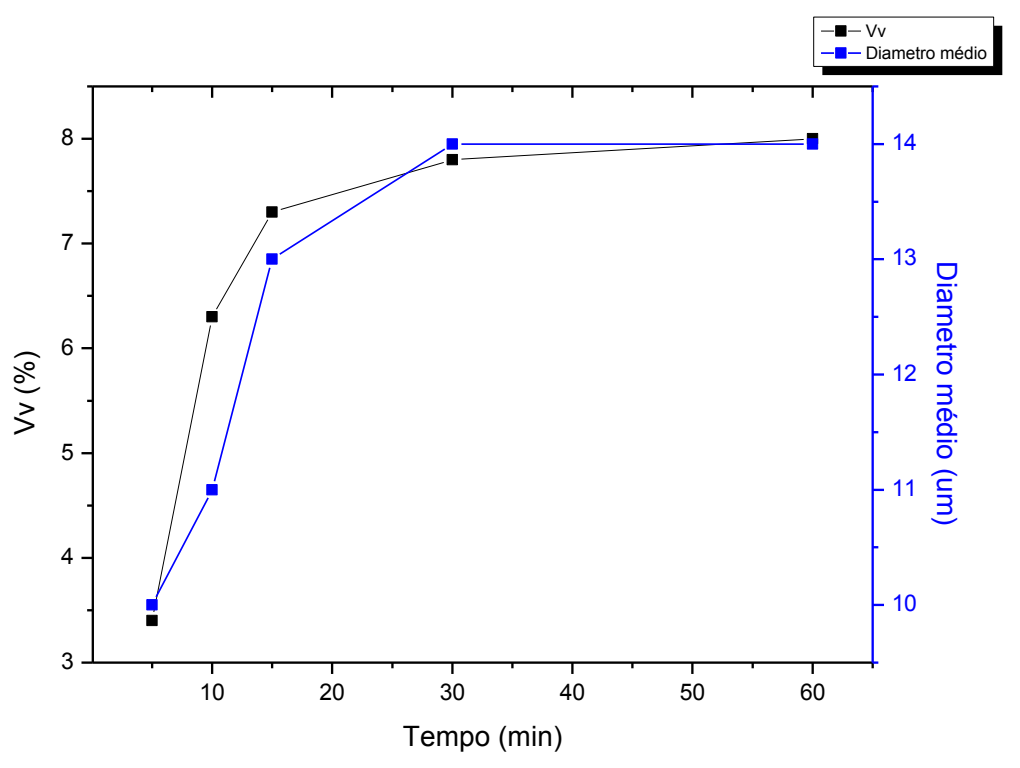

Figura 38 - Comparação de $V v$ e diâmetro médio de grafita para diferentes tempos de austenitização FBM

\subsubsection{RESULTADOS DE DUREZA}

A dureza é praticamente constante até sete minutos de tratamento de austenitização, como mostra a Figura 39. Até 15 minutos de tratamento térmico de austenitização a dureza apresentou-se acima da dureza especificada para materiais para rolamento. Neste estágio o material apresenta uma estrutura potencialmente interessante, pois apresenta carbonetos isolados com bordas arredondadas (como em aços para rolamento) e grafita, ou seja uma distribuição de partículas finas isoladas de alto módulo elástico convivendo com partículas de material auto-lubrificante. A redução da dureza subsequente está associada a dissolução de cementita e ao 
crescimento dos nódulos de grafita.

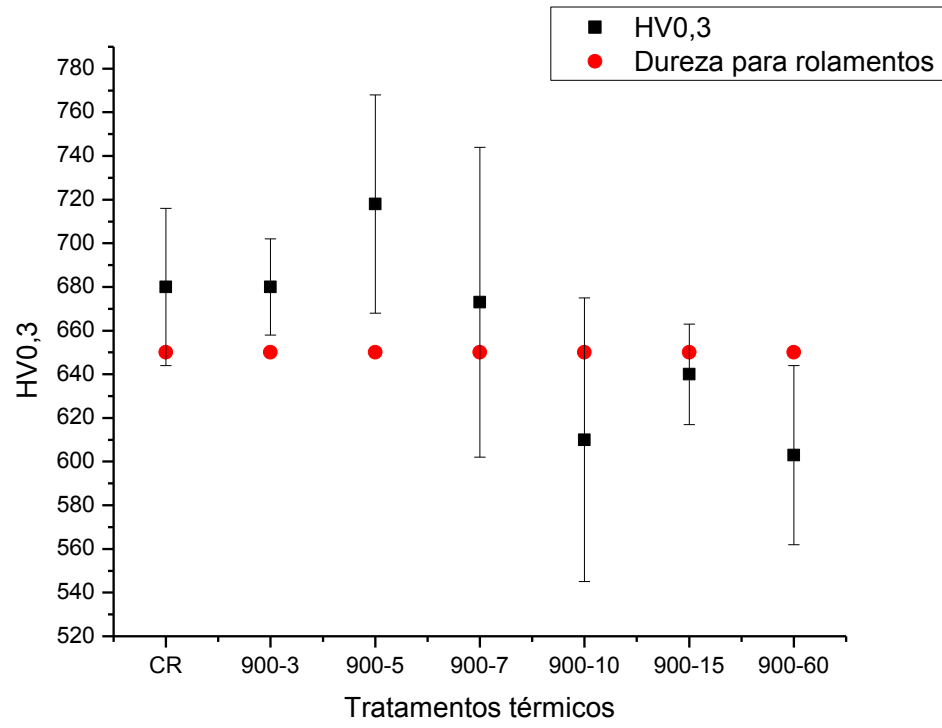

Figura 39 - Medida de dureza Vickers das amostras FBM.

\subsubsection{Ensaios de dilatometria}

Analisando a Figura 40, observa-se que o tempo de tratamento térmico de austenitização influencia na expansão final das amostras ensaiadas no dilatômetro. Quanto maior o tempo de tratamento de austenitização a $900{ }^{\circ} \mathrm{C}$, maior a expansão das amostras ensaiadas. A maior expansão está correlacionada com a dissolução de cementita e formação de grafita no PEG. A formação e crescimento do tamanho dos nódulos de grafita, proporcionam a expansão final da amostra analisada.

O início da transformação martensítica também pode ser determinada utilizando o método das retas tangentes na Figura 40. A Tabela 9 mostra o valor de Ms para os diferentes tempos de austenitização. A porcentagem de carbono na austenita para os diferentes tratamentos foi calculada (Tabela 9), usando a equação de Andrews tendo como variante o Ms (Tabela 9) e valores fixos a porcentagem em peso dos elementos de liga. Verifica-se analisando os dados que a concentração de carbono na austenita passa a ficar constante após 10 minutos de tratamento de austenitização.

Surpreendentemente, a aplicação da equação de Andrews para estimar o início da transformação martensítica usando as concentrações de elementos químicos na 
fase austenita (obtida através do Thermo-Calc®) não se revelou válida, pois o Ms determinado por este método foi $120^{\circ} \mathrm{C}$, enquanto que o determinado por dilatometria ficou na faixa de $232-217^{\circ} \mathrm{C}$ (Tabela 9). Esta discrepância de valores provavelmente explica-se pelas condições longe do equilíbrio termodinâmico na austenitização, além de micro segregação originaria da estrutura de solidificação.

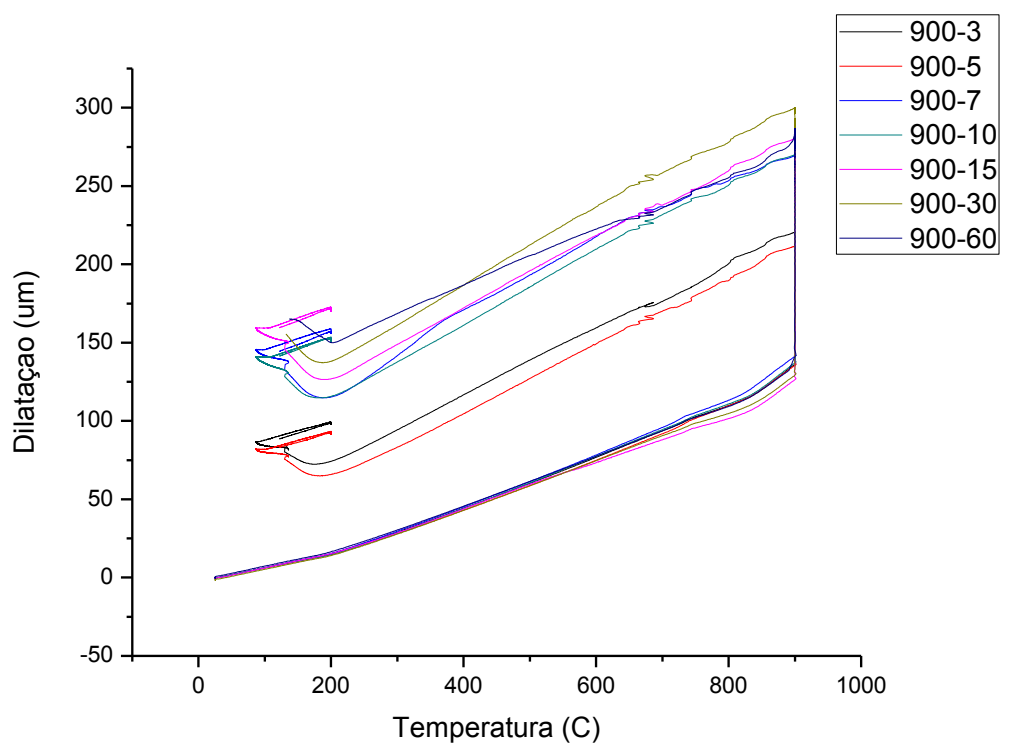

Figura 40 - Curva temperatura VS dilatação de amostras de ferro fundido branco na condição bruta de solidificação.

Tabela 9 - Ms obtidos a partir de ensaios dilatométricos usando o método da reta tangente e \%C na austenita determinado a partir da equação de Andrews.

\begin{tabular}{|c|c|c|}
\hline Tratamento & $\mathbf{M s}\left({ }^{\circ} \mathbf{C}\right)$ & \%C \\
\hline $900-3$ & 232 & 0,62 \\
\hline $900-5$ & 219 & 0,65 \\
\hline $900-7$ & 225 & 0,63 \\
\hline $900-10$ & 217 & 0,65 \\
\hline $900-30$ & 217 & 0,65 \\
\hline
\end{tabular}

A equação de cinética para as reações originadas durante o PEG foi obtida a partir dos resultados obtidos no tratamento a $900{ }^{\circ} \mathrm{C}$ durante sessenta minutos (Figura 41). Analisando esta curva percebe-se que a dilatação em tempos próximos a 30 minutos tende a um valor constante. 


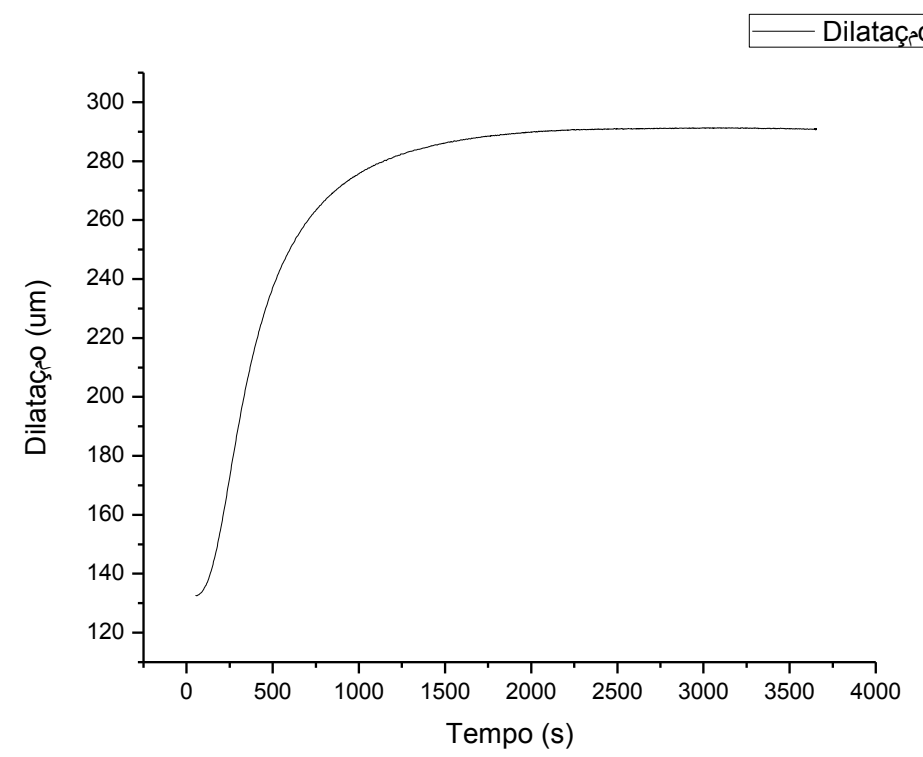

Figura 41 - Curva tempo vs dilatação da amostra 900-60.

A fração volumétrica foi determinada usando a metodologia descrita no capítulo 4 para o ferro fundido cinzento, e o gráfico representativo da fração volumétrica é mostrado na Figura 42a. A Figura 42b apresenta a curva linearizada plotada em $\ln (\ln (1 /(1-\mathrm{y})$ versus $\ln (\mathrm{t})$, separando em trechos as frações transformadas de grafita, respectivamente, 0,4,0,5 e 0,95. Note-se que a fração transformada de grafita não corresponde à $100 \%$ do volume, mas sim à fração de grafita em equilíbrio com a austenita na temperatura do ensaio.

(a)
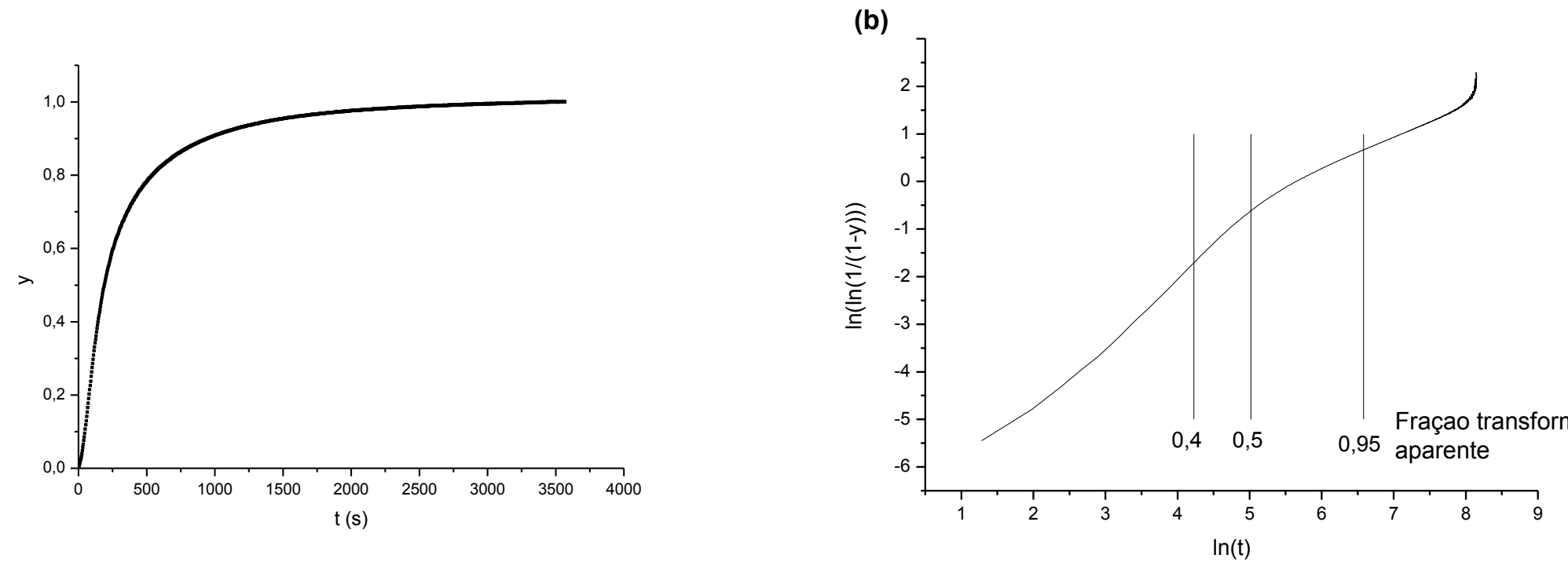

Figura 42 - curva de cinética das amostras de ferro branco ensaiadas no dilatômetro Bähr (a);

Curva linearizada com indicação das frações transformadas(b); 
Metodologias diferentes para a determinação da equação de cinética foram encontradas na literatura. Burke [47] estimou a cinética de nódulos de grafita durante o tratamento de maleabilização usando metalografia quantitativa dos maiores nódulos; os resultados segundo Burke são representativos dos primeiros $50 \%$ da fração transformada sendo estes resultados associados a etapa de nucleação de grafita. A equação de cinética proposta na literatura [39] pode ser determinada a partir do trecho linear.

No presente trabalho equações de cinética usando as duas metodologias foram obtidas. Este procedimento resultou em dois trechos distintos. A curva ajustada para uma reta no primeiro trecho, correspondente aos primeiros $50 \%$ da transformação, tal qual proposto por BURKE, segue na Figura 43. O coeficiente $n$ e $K$ valem respectivamente: 1,38 e 5,2128E-4. Para o segundo trecho, a linearização foi ajustada para a faixa de frações de fase de 0,4 e 0,95 (40\% e 95\%). O valor de n e K para este trecho valem respectivamente: 0,7 e 1,8413E-2 (Figura 44).

O ajuste linear feito nos dois trechos pode ser acompanhado na Figura 45, apresentando o ajuste linear para os dois trechos respectivamente: 0-05 e 0,4-0,95 da fração aparente transformada.

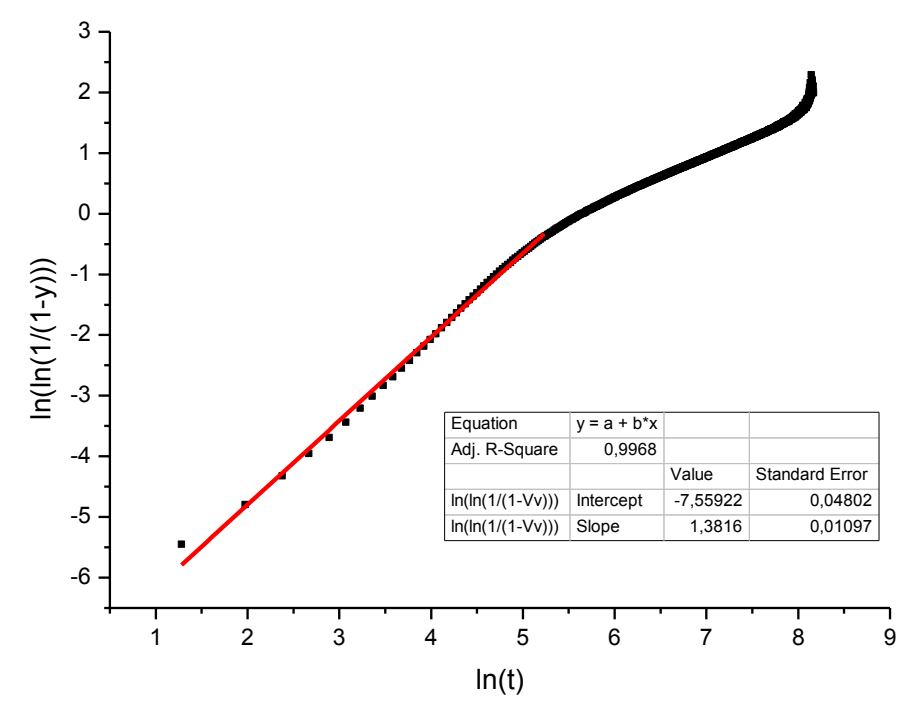

Figura 43 - Linearização dos primeiros $50 \%$ da transformação 


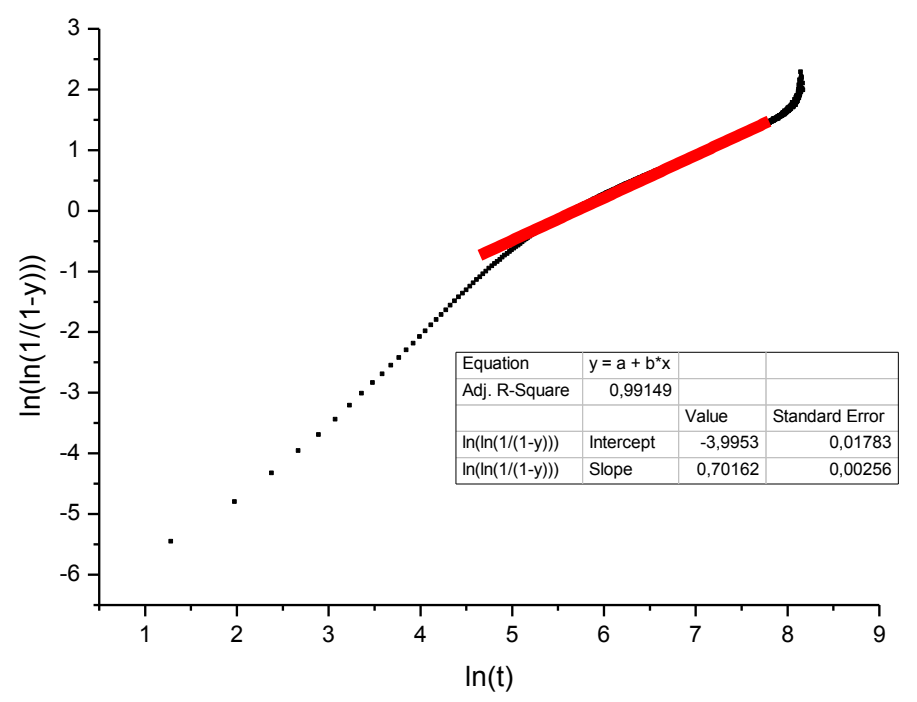

Figura 44 - Linearização entre 0,4 e 0,95 da transformação

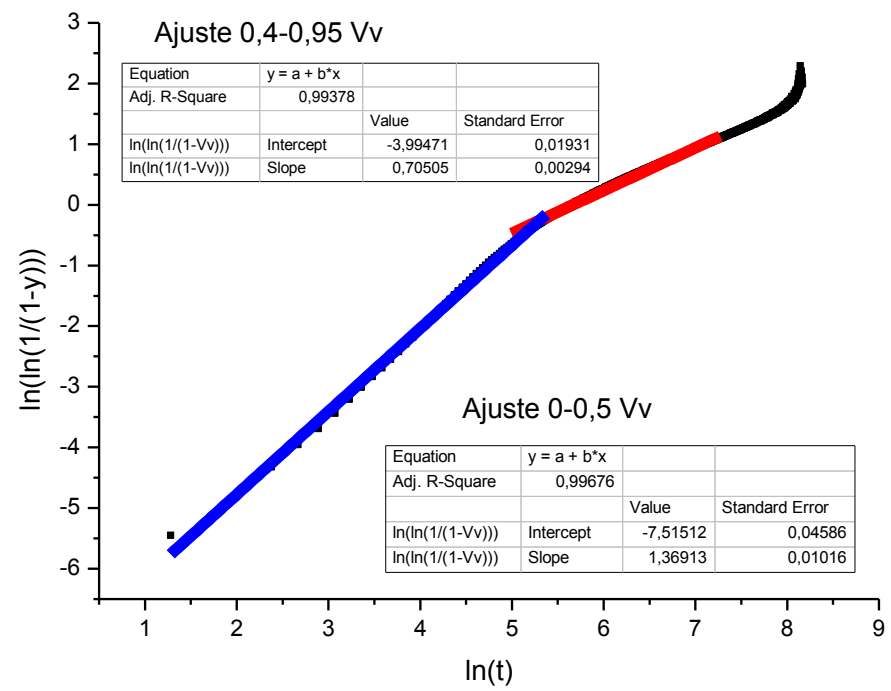

Figura 45 - Curva total mostrando os dois trechos de linearização

A energia de ativação obtida a partir das reações presentes no tratamento isotérmico foi determinada a partir de tratamentos isotérmicos efetuados em três temperaturas diferentes $\left(850,900\right.$ e $\left.950^{\circ} \mathrm{C}\right)$ durante uma hora. A linearização da curva foi feita a partir de 0,4-0,95 da fração transformada (usando a equação de velocidade de Arrhenius (equação 31). Onde: $\mathrm{K}$ é a constante de velocidade determinada anteriormente; $Q$ é a energia de ativação; $R$ a constante de gases e $T$ a temperatura absoluta em $\mathrm{K}$. 


$$
K=K_{0} \cdot \exp \left(-\frac{Q}{R \cdot T}\right)
$$

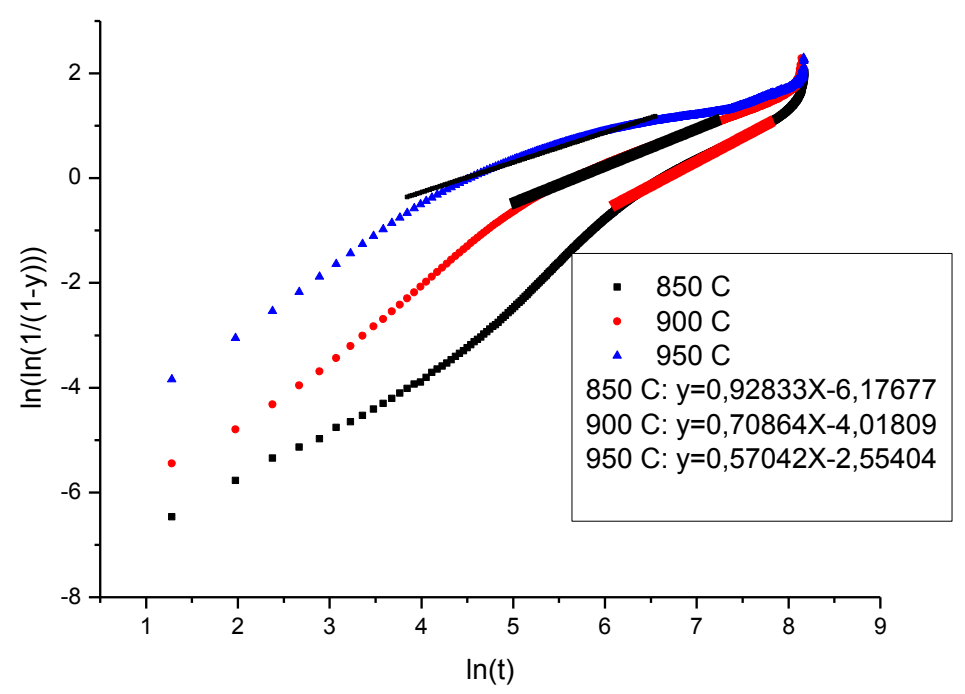

Os dados foram traçados em um gráfico $\ln (\mathrm{K})$ versus $1 / \mathrm{T}$. Para os valores de $1 / \mathrm{T}\left(8,9.10^{-4} ; 8,52.10^{-4}\right.$ e 8,18.10-4) foram utilizados os respectivos valores de $\ln (\mathrm{K})(-$ $6,6536 ;-5,6701 ;-4,47747)$. Os três pontos foram ajustados por regressão linear por uma reta, como mostra a Figura 46. Pela linearização da equação 32 , a inclinação desta reta equivale ao valor de $-Q / R$, Assim, dado que a constante universal de gases é igual a 8,314462 J.mol-1.K $\mathrm{K}^{-1}$, a energia de ativação aparente da reação de grafitização foi determinada em $248 \mathrm{KJ} / \mathrm{mol}$.

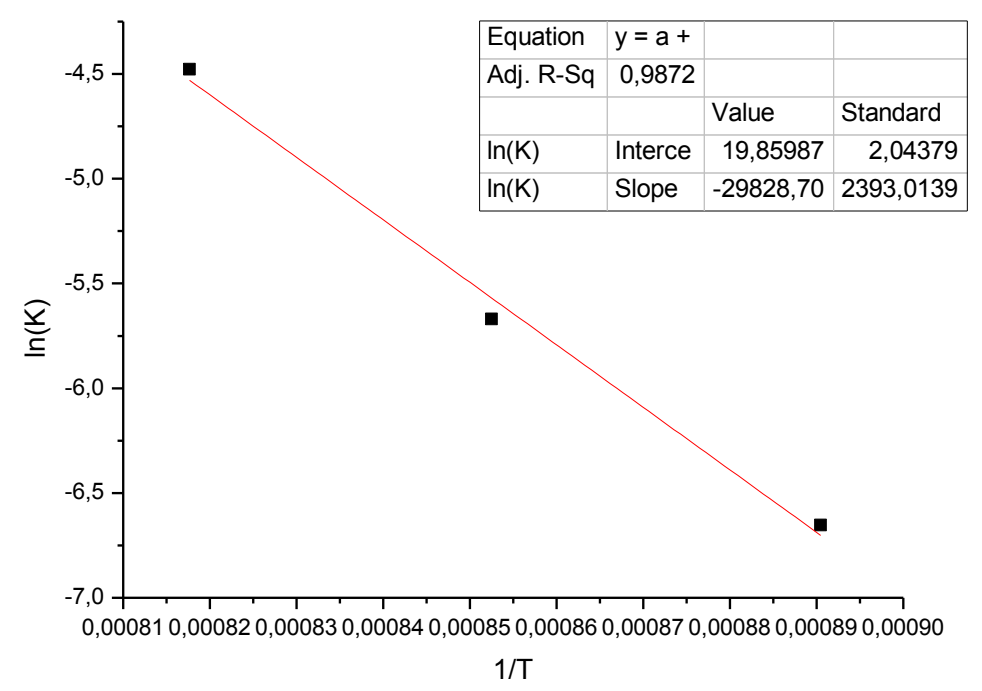

Figura 46 - Determinação da energia de ativação em diferentes temperaturas de tratamento isotérmico $\left(850,900\right.$ e $\left.950^{\circ} \mathrm{C}\right)$. 


\subsection{DISCUSSÃO DOS RESULTADOS APRESENTADOS}

O ferro branco utilizado neste estudo foi solidificado a uma alta taxa de resfriamento, proporcionando uma grande área interfacial, favorecendo a formação dos núcleos de grafita [47]. Na amostra bruta de solidificação já são observados alguns nódulos, Figura 31; além disto, nada impede que a nucleação dos nódulos de grafita não possa ocorrer durante o aquecimento da amostra como foi visto na revisão bibliográfica (Figura 25). Pode também ocorrer nucleação nos instantes iniciais do tratamento isotérmico. Uma possível hipótese a respeito da continuidade da nucleação nos tratamentos isotérmicos a $900{ }^{\circ} \mathrm{C}$, provém dos resultados de cinética (início da transformação até 50 \%) apresentado na Figura 43. A curva para este trecho não é completamente linear e o valor de $n=1,38$. Segundo a teoria [39] analisando o grupo onde a etapa controladora é a interface, valores próximos de $n=1$ indicam que a nucleação ocorre em contornos de grãos após saturação, ou seja, a área interfacial de cementita é a etapa controladora para a formação dos núcleos de grafita.

A etapa de crescimento dos nódulos de grafita pode ser controlada pela difusão do Si presente na austenita próximo à interface da cementita, pela auto-difusão de Fe ou pela dissolução de cementita. A concentração de Si próximo à interface, segue o raciocínio proposto por BURKE [47]: em um ferro branco resfriado rapidamente a partir do estado líquido, a cementita em crescimento poderá rejeitar o Si e se concentrar na austenita junto à interface da cementita. A energia de ativação aparente obtida experimentalmente foi $248 \mathrm{KJ} / \mathrm{mol}$ e é próxima à energia de ativação para difusão do Si na austenita ${ }^{1}(285 \mathrm{KJ} / \mathrm{mol})$ e da energia de ativação da auto-difusão do $\mathrm{Fe}$ na austenita $(284 \mathrm{KJ} / \mathrm{mol})$. Os átomos de Fe ou Si precisam se movimentar a frente da interface de grafita em crescimento de modo a criar espaços vazios para que a grafita cresça. Ao mesmo tempo que os átomos (Fe ou Si) se movimentam a frente da interface em crescimento, a dissolução de cementita também está ocorrendo. A dissolução de cementita em tempos crescentes de tratamento isotérmico a $900{ }^{\circ} \mathrm{C}$ foi

\footnotetext{
1 A energia de ativação para a difusão do $\mathrm{Si}$ na austenita foi estimada a partir de resultados apresentados no trabalho de ATKINSON [71] usando o coeficiente de difusão na austenita $(1,8 \mathrm{E}-18$, $8,4 \mathrm{E}-18,3,5 \mathrm{E}-17$ e $1,3 \mathrm{E}-16)$ e suas respectivas temperaturas $\left(750,800,850\right.$ e $\left.900{ }^{\circ} \mathrm{C}\right)$. A metodologia para a obtenção da energia de ativação foi a mesma utilizada neste trabalho, ou seja, a dependência do coeficiente de difusão em função da temperatura pela equação de Arrhenius.
} 
comprovada a partir das análises metalográficas.

A curva de dilatometria da Figura 41 mostra que a transformação foi completada após os 60 minutos de ensaio. De forma análoga, os resultados de metalografia quantitativa (Figura 38) confirmam o resultado de dilatometria, uma vez que o diâmetro médio de grafita e a fração volumétrica tendem a um valor constante. A análise dos resultados mostra que a transformação para este ferro branco foi completada ao redor de 30 minutos de tratamento isotérmico à $900{ }^{\circ} \mathrm{C}$.

Durante a maleabilização a $900^{\circ} \mathrm{C}$ também foi observada a diminuição da temperatura Ms para tempos crescentes de tratamento térmico (Tabela 9). Foi observada a tendência de que nos primeiros minutos de tratamento há uma ligeira queda e partir de 10 minutos o Ms se estabiliza em $217^{\circ} \mathrm{C}$. Este resultado indica que durante o tratamento térmico a austenita é enriquecida em soluto (seja $\mathrm{Si}$ ou C). Curiosamente, a estimativa da temperatura Ms usando a equação de Andrews, aplicada à composição química da austenita em equilíbrio com a grafita calculada usando Thermo-Calc $®$ foi bem diferente da medida, sendo em torno de $120^{\circ} \mathrm{C}$. Esta discrepância revela que esta metodologia não é confiável para determinação do Ms. É possível que a equação de Andrews não é confiável para estes teores de elementos de liga (alto $\mathrm{C}$ e alto $\mathrm{Si}$ ). Além disso, a estimativa de composição química da austenita calculada pelo software Thermo-Calc® pode ser uma fonte de erro. Uma vez que a temperatura Ms é muito sensível ao teor de carbono, pequenas variações na concentração de carbono podem originar grandes diferenças entre 0 valor experimental e teórico. Outras razões para esta discrepância são que a presença de alguns carbonetos esferoidizados pode indicar que o equilíbrio da austenita ainda é com a cementita (diagrama metaestável) e não com a grafita (diagrama estável) e pode estar afetado ainda pela heterogeneidade intrínseca dos ferros fundidos, devido à segregação durante a solidificação. A estimativa do Ms usando Andrews acoplado a Thermo-Calc® deve ser usado apenas como indicação qualitativa e não tomada como uma previsão acurada quando se trata de ferros fundidos brancos maleabilizados. Usou-se o raciocínio reverso para estimar a concentração de carbono na austenita usando como dados o valor do Ms obtido por dilatometria $\left(217^{\circ} \mathrm{C}\right)$ e a composição da liga na equação de Andrews; o valor estimado de carbono foi 0,652 \%, indicando que na realidade a concentração de carbono para este material é nem menor que os simulados usando ThermoCalc.

A morfologia da grafita encontrada não é de esferulitos perfeitos; embora 
equiaxiais, os nódulos apresentam interface "rasgada" e cheia de pontas, mesmo com longos períodos de maleabilização onde está presente um crescimento (engrossamento ou "maturação de Ostwald") dos nódulos. Esta morfologia da grafita é compatível com o descrito na literatura para ferros fundidos maleáveis com composição de ferro fundido cinzento comercial [2].

O produto da maleabilização por tempos curtos é potencialmente um material muito interessante para aplicações tribológicas, como por exemplo aquelas em que há contato metal/metal lubrificado e tensões hertzianas, como em superfícies de sistemas came-seguidor e outras semelhantes em motores de combustão interna. Isto porque o material até 15 minutos de tratamento apresenta dureza dentro da faixa especificada para rolamentos de esferas (dureza de cerca de $650 \mathrm{HV}$ ), e apresenta uma microestrutura contendo carbonetos isolados com os cantos arredondados (como os aços para rolamento) e grafita, ou seja, uma distribuição de partículas finas isoladas de alto módulo elástico convivendo com partículas de material auto-lubrificante. A redução da dureza subsequente observada para tempos maiores está associada a dissolução da cementita e ao crescimento dos nódulos de grafita (dureza de $600 \mathrm{HV}$ após 60 minutos de tratamento). 


\subsection{CONCLUSÕES}

- Os tempos encontrados para o primeiro estágio de grafitização PEG foram mais curtos do que os descritos na literatura. Isto se deve provavelmente ao refinamento da estrutura eutética e da cementita, e pode ainda estar relacionado à composição da liga, com baixos teores de $\mathrm{Cr}$ e $\mathrm{Mn}$.

- A cinética medida experimentalmente pode ser descrita por uma equação do tipo Johnson-Mehl-Avrami-Kolmogorov [39], no formato utilizado por Burke [46] em seus estudos clássicos sobre maleabilização: $Y=1-\exp \left[-(k \cdot t)^{n}\right]$, onde o n encontrado foi 1,38 , que nos modelos cinéticos da literatura corresponde à controle por difusão, com saturação dos locais para a nucleação.

- Foi possível obter uma energia de ativação aparente (248 KJ/mol) para o PEG utilizando diferentes temperaturas; este resultado é compatível com a hipótese de que a etapa que controla o crescimento da grafita é a difusão do Si e do Fe necessária para abrir espaço para o crescimento dos nódulos de grafita, uma vez que a energia de ativação para estes elementos na austenita é próxima a este valor ( $285 \mathrm{KJ} / \mathrm{mol})$.

- A concentração de carbono na austenita, estimada a partir das temperaturas Ms obtidas por dilatometria, aumenta ligeiramente para tempos curtos e estabiliza-se a partir de 10 minutos de tratamento a $900^{\circ} \mathrm{C}$.

- A morfologia da grafita encontrada é de esferulitos degenerados, com pontas e interface tipo rasgada.

- Nos tratamentos até 15 minutos a $900^{\circ} \mathrm{C}$ a grafita convive com carbonetos esferoidizados e a dureza média após a têmpera é muito elevada, dentro da faixa especificada para aços de rolamento. Para tempos maiores a grafita coalesce e a cementita finalmente desaparece, com consequente diminuição da dureza. 


\section{ENSAIOS DE DESGASTE POR DESLIZAMENTO}

\subsection{INTRODUÇÃO TEÓRICA}

\subsubsection{Desgaste por deslizamento}

O termo desgaste pode ser definido como a perda de material, devido ao movimento relativo de superfícies e substâncias em contato; com suas superfícies em contato, a força que imprime uma resistência a esse movimento é chamada de atrito. O movimento relativo entre essas superfícies pode proporcionar danos a uma superfície ou em ambas, ocasionando perda progressiva de material. A perda de material mesmo que em pequena quantidade pode originar falhas em máquinas mais complexas [20].

Em suma, desgaste por deslizamento é o desgaste originado quando duas superfícies em contato deslizam uma sobre a outra.

\subsubsection{Coeficiente de atrito}

Segundo HUTCHINGS [20], o coeficiente de atrito é definido pela razão entre a força tangencial que se opõe ao movimento $\left(F_{\text {at }}\right)$ e a força normal que atuam nos corpos durante o movimento $(L)$, como pode ser verificado na equação 32 .

$$
\mu=\frac{F_{a t}}{L}
$$

O coeficiente de atrito é um parâmetro importante e tem sido utilizado para melhorar processos industriais, por cientistas e engenheiros na busca por melhorias de projetos de máquinas e equipamentos. No entanto, o coeficiente de atrito não pode ser calculado pela equação 33 porque o coeficiente de atrito é caracterizado pelo comportamento do material em um determinado ambiente e pode ser influenciado por diferentes fatores como: condições ambientais, rugosidade entre superfícies, variações de temperatura, tipo de lubrificante, orientação cristalográfica da superfície e ainda a escolha do tipo de teste, assim como, a montagem do aparato experimental $[20,51]$. Por todos estes motivos ainda não há um consenso do significado do 
coeficiente de atrito, sendo necessário tomar cuidado ao analisar este parâmetro antes de aplicá-lo em algum projeto.

\subsubsection{Contato entre duas superfícies}

Quando dois materiais sólidos são colocados em contato, originam-se tensões inerentes a este contato. Inicialmente, é necessário definir o tipo de contato: conforme e não-conforme. Contato conforme (Figura 47a) acontece quando duas superfícies colocadas em contato se ajustam perfeitamente macroscopicamente. Dois corpos colocados em contato e se tocam em um único ponto em duas superfícies não similares é chamado de contato não-conforme (Figura 47b) [20].

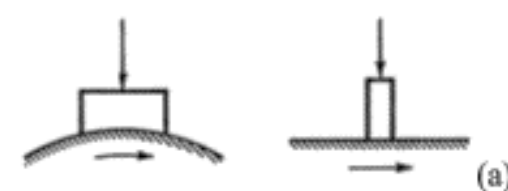

(a)
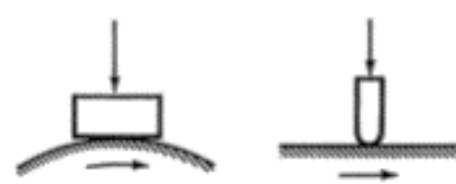

(b)

Figura 47 - (a) contato conforme; (b) contato não-conforme. [20]

O primeiro estudo satisfatório sobre contato elástico entre sólidos é atribuído a Heinrich Rudolph Hertz que, analisando experiências com lentes ópticas elípticas, percebeu que a aplicação de uma força sobre as lentes produzia uma deformação elástica, influenciando de maneira significativa o padrão das franjas de interferência [52].

Hertz, assumindo superfícies idealmente lisas e isentas de atrito, supôs que a área de contato é elíptica e que cada corpo pode ser considerado como um semiespaço elástico carregado em uma pequena área de sua superfície plana. Johnson [53] salienta que essa simplificação, seguida na teoria de tensões de contato, trata-a separadamente da distribuição geral de tensões nos corpos em análise e a validade dessa simplificação deve respeitar duas condições: as dimensões da área de contato devem ser pequenas quando comparadas a a) as dimensões dos sólidos em contato e b) ao raio relativo de curvatura das superfícies. A figura geométrica idealizada por Hertz pode ser observada na Figura 48. 


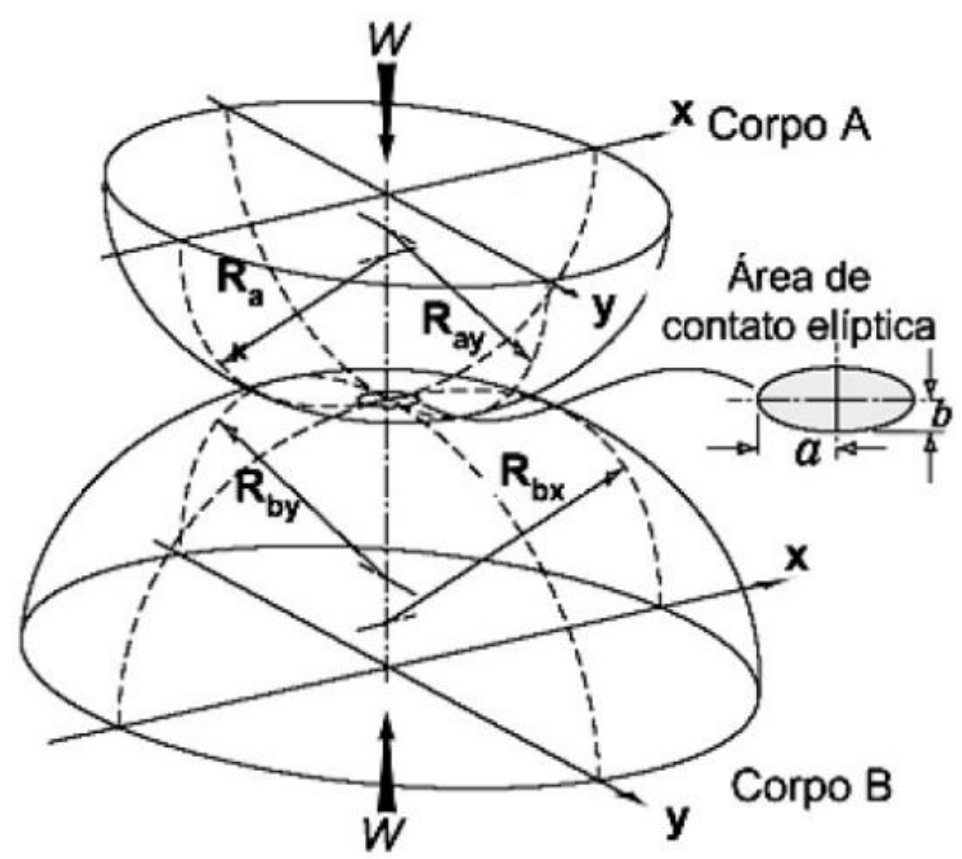

Figura 48 - Contato elástico entre dois corpos elípticos [51].

Os eixos coordenados $x$ e $y$ representam as direções segundo o maior e o menor semieixo dos sólidos $\mathrm{A}$ e $\mathrm{B}$, respectivamente. $R_{a x}, R_{b x}, R_{a y}$ e $R_{b y}$ representam os raios de curvatura dos corpos $A$ e $B$, respectivamente, nas direções $x$ e $y$. Essas dimensões permitem a determinação do raio reduzido de curvatura, $R$ ', definido na equação (33), que é utilizado no cálculo das tensões de contato envolvendo corpos elípticos.

$$
\frac{1}{R^{\prime}}=\frac{1}{R_{X}}+\frac{1}{R_{Y}}=\frac{1}{R_{a x}}+\frac{1}{R_{a y}}+\frac{1}{R_{b x}}+\frac{1}{R_{b y}}
$$

O resultado de Hertz pode ser estendido para o contato existente entre um corpo esférico A e corpo de superfície plana B, como ilustrado na Figura 49. Para tanto, basta assumir que $R_{a x}=R_{a y}=R$ e $R_{b x}=R_{b y}=\infty$. Nessa situação, a região de contato entre os dois corpos trata-se de uma área circular de raio $a$, cujo valor pode ser calculado pela equação (34). 


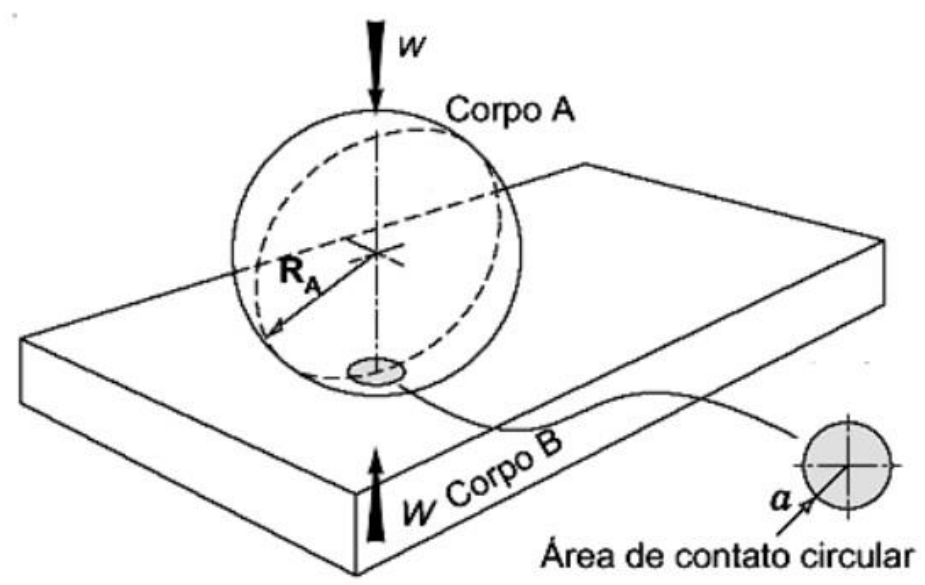

Figura 49 - Contato esfera contra plano em um carregamento elástico [17].

$$
a=\left(\frac{3 W R}{4 E^{*}}\right)^{\frac{1}{3}}
$$

em que a é o raio da área de contato, $W$ é a carga aplicada, $R$ é o raio da esfera e $E^{*}$ é o modulo de elasticidade combinado dos materiais (esfera e plano).

Existem duas formas de calcular o módulo: módulo elástico combinado $\left(E^{*}\right)$ e o módulo elástico reduzido. O módulo elástico combinado é calculado usando-se a equação (35) [54]. O módulo elástico reduzido é expresso pela equação (36) [51]. O presente trabalho utiliza o módulo elástico reduzido seguindo a proposta de Stachowiack para o cálculo da área real de contato [51].

A pressão média de contato e a área de contato foram determinadas pelas equações (37) e (38) .

$$
\begin{gathered}
\frac{1}{E^{*}}=\frac{\left(1-v_{a}^{2}\right)}{E_{a}}+\frac{\left(1-v_{b}^{2}\right)}{E_{b}} \\
\frac{1}{E^{\prime}}=\frac{1}{2}\left(\frac{\left(1-v_{a}^{2}\right)}{E_{a}}+\frac{\left(1-v_{b}^{2}\right)}{E_{b}}\right) \\
P_{\text {média }} \approx \frac{W}{\pi a^{2}} \\
A_{c} \approx 0,83 \pi\left(\frac{W R}{E^{*}}\right)^{\frac{2}{3}}
\end{gathered}
$$

No sistema anel-cilindro ocorre o deslizamento entre os corpos, o contato é do tipo lubrificado entre superfícies não conformes, como mostra o esquema da Figura 50. Devido às variações de carga, velocidade e estado da superfície de contato do 
cilindro, as condições de lubrificação entre o anel e o cilindro são extremamente transientes, as quais refletem na variação do coeficiente de atrito e no comportamento em relação ao desgaste.

Os mecanismos de atrito atuante entre os anéis de pistão e o cilindro durante o funcionamento do motor incluem uma combinação de lubrificação limítrofe e elastrohidrodinâmica, no ponto morto inferior e superior do mecanismo biela-manivela. Já no meio-curso de funcionamento do pistão apresentam um comportamento hidrodinâmico de lubrificação [55]. Diante disso e com o objetivo de subsidiar o entendimento do tribossistema anel-cilindro, objeto dessa tese, em seguida são apresentados os regimes de lubrificação em sistemas deslizantes para este modo de desgaste encontrados na literatura.

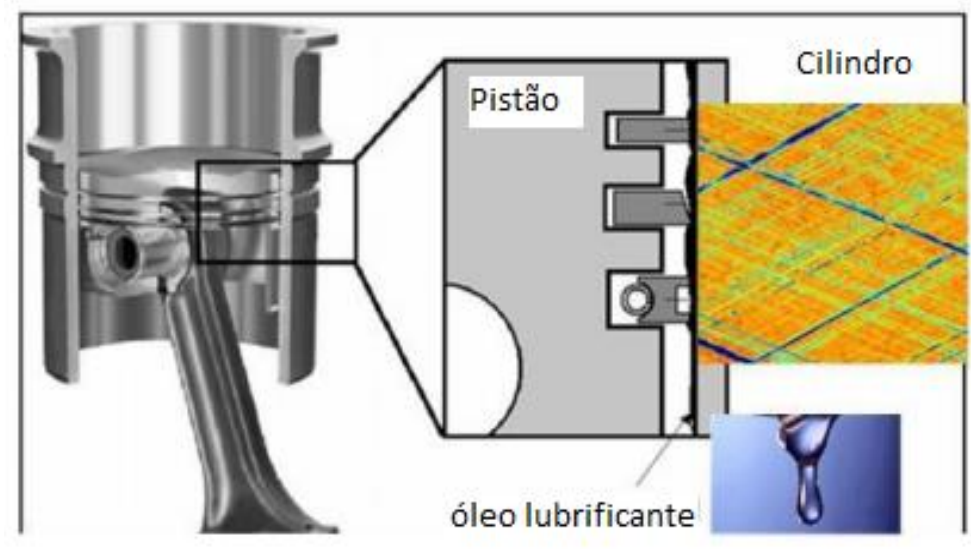

Figura 50 - Tribossistema anel/lubrificante/cilindro.

\subsubsection{Regimes de Lubrificação}

Entre duas superfícies lubrificadas podem se estabelecer três regimes de lubrificação: limítrofe, elasto-hidrodinâmico (EHD) e hidrodinâmico (HD). Esses regimes podem ser analisados empregando-se a curva de Stribeck, cujas curvas de maior aceitação são apresentadas na Figura 51 e Figura 52. Alguns autores eventualmente descrevem transições que apresentam comportamentos mistos entre dois regimes de lubrificação, como é explicitado na Figura 52a).

Essa curva possui duas versões, uma mostra o coeficiente de atrito em função do número de Sommerfeld e a outra mostra o coeficiente de atrito em função da separação entre as superfícies (Figura 52).

Analisando a curva de Stribeck para um mancal lubrificado (coeficiente de atrito 
versus número de Sommerfeld, Figura 51), a redução da carga (W) e o aumento da velocidade de deslizamento $(U)$, o regime segue em direção ao regime hidrodinâmico. Por outro lado, altas cargas e baixas velocidades de deslizamento ocasionam a perda de capacidade de sustentação do lubrificante, conduzindo o tribossistema em direção ao regime limítrofe. Nesta condição, o contato entre as asperezas das duas superfícies não pode ser evitado, proporcionando a elevação do coeficiente de atrito e da taxa de desgaste [51].

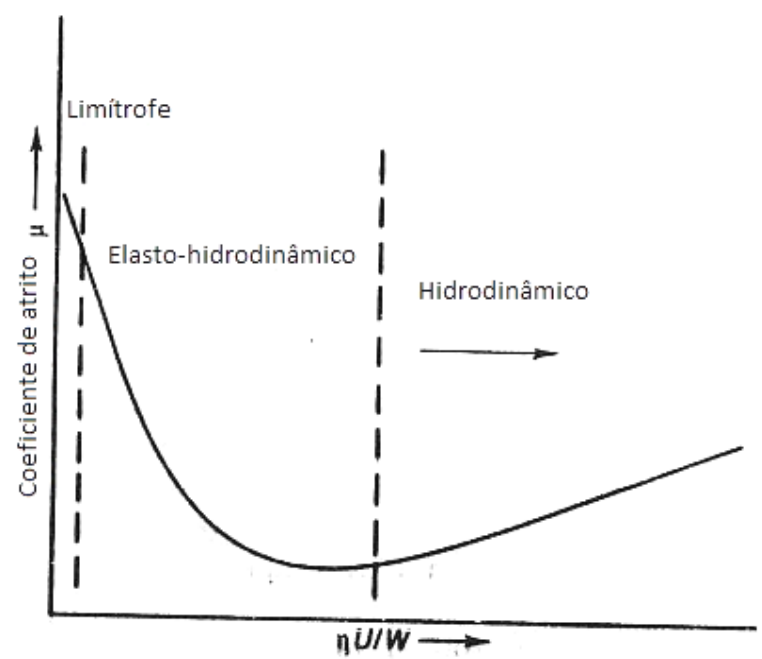

Figura 51 - Curva de Stribeck para um rolamento lubrificado [20].

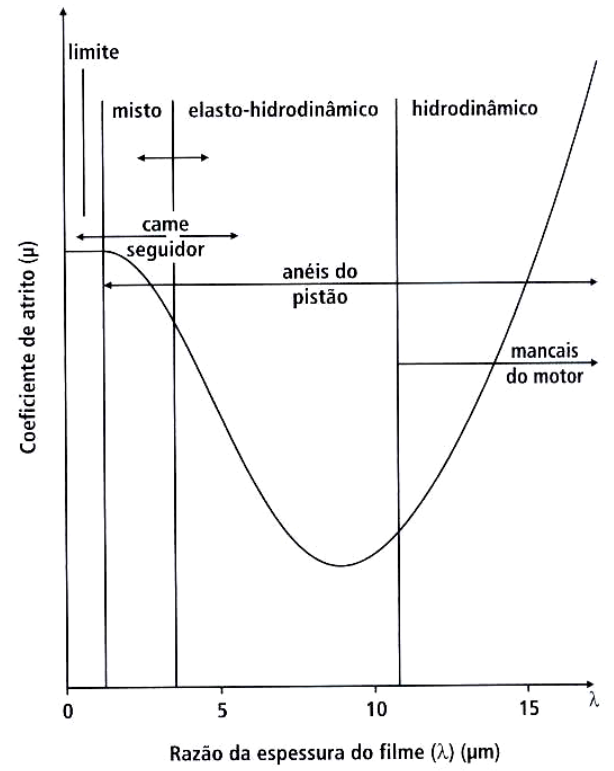

(a)

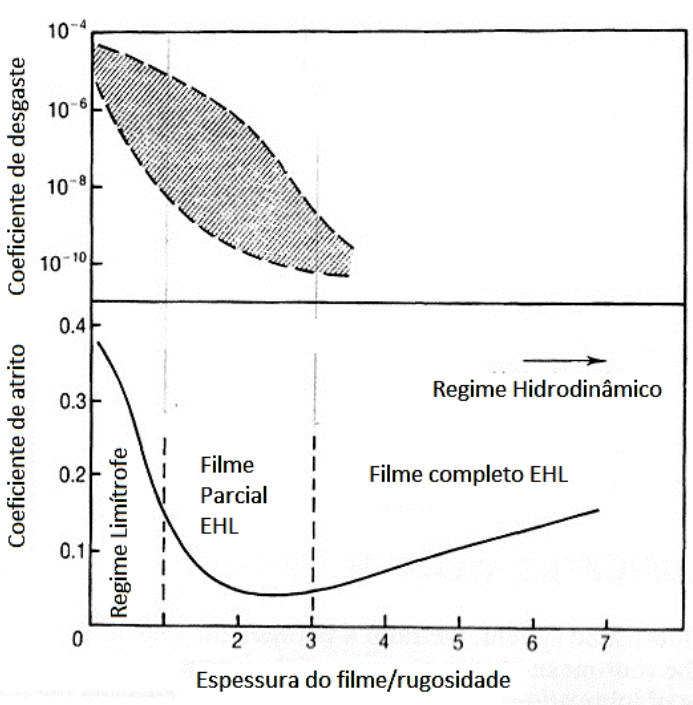

(b)

Figura 52 - Curva de Stribeck (a) [12]; Regimes de lubrificação e desgaste no desgaste por deslizamento em regime lubrificado (b) Adaptado da referência [51]. 
A curva de Stribeck também foi estudada por Gumbel e Hersey, dez anos após a publicação de Stribeck em esferas de rolamento lubrificados. Os autores traçaram o coeficiente de atrito em função de um número adimensional $\eta \mathrm{N} / P_{h}$, onde $\eta$ é a viscosidade do fluido dado em $\mathrm{Pa}$.s, $\mathrm{N}$ é a velocidade angular em rotações por minuto e $P_{h}$ é a pressão em $\mathrm{Pa}[56]$.

A curva de Stribeck típica seja como a da Figura 53.

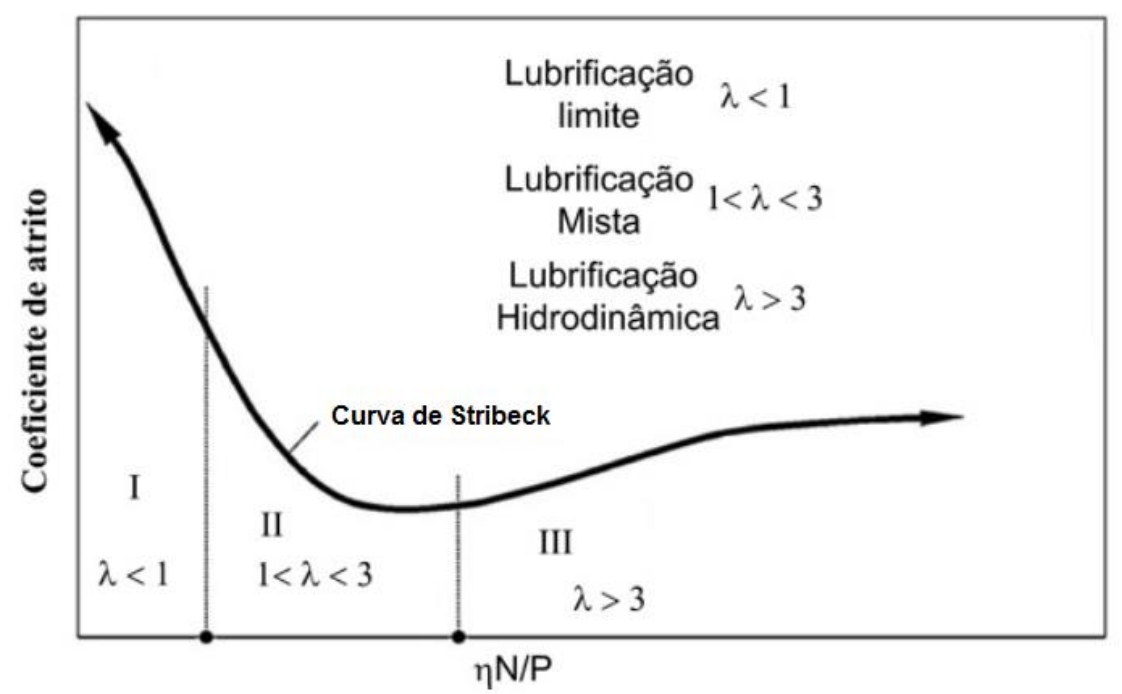

Figura 53 - Curva de Stribeck, adaptado da referência [56].

A curva de Stribeck em relação ao coeficiente de atrito versus separação entre superfícies (Figura 52) apresenta os regimes de lubrificação, onde ações físicas e químicas são desconsideradas [12,20].

A espessura do filme de lubrificante entre a média quadrática das asperezas mais altas determina o tipo de regime. $O$ parâmetro $\lambda$ é determinado pela relação entre a espessura mínima do filme lubrificante, $h_{\min }$, e rugosidade composta das superfícies, conforme definido na equação (39).

$$
\lambda=\frac{h_{\min }}{\sqrt{R q_{a}^{2}+R q_{b}^{2}}}
$$

em que $R q_{a}$ e $R q_{b}$ são as rugosidades quadráticas médias das superfícies em contato.

Os regimes de lubrificação podem ser identificados a partir dos valores de $\lambda$. As superfícies estão completamente separadas por um filme lubrificante quando $\lambda>3$ (regime elasto-hidrodinâmico). Valores de $\lambda$ entre $1<\lambda<3$ caracterizam o regime de lubrificação misto, ou seja, apenas algumas asperezas entram em contato. Valores de 
$\lambda$ menores que 1 caracterizam o regime de lubrificação limítrofe, sem a formação de um filme fluido [20], ou seja, ocorre um contato frequente entre asperezas, separada apenas por monocamadas de moléculas de aditivos [12,20].

Os coeficientes de desgaste ( $k$ ) na Figura $52 \mathrm{~b}$ ) atingem valores até $10^{-4}$. Para fins comparativos, o desgaste é moderado quando o coeficiente é menor que $10^{-6} \mathrm{o}$ que dá ideia de incipiência dos desgastes nestes regimes de lubrificação. Entretanto, para valores baixos de $k$ estão correlacionados a valores críticos de desgaste baixo. O valor crítico de desgaste é o valor máximo (absoluto) tolerado num componente. No caso de anéis versus camisa, o valor de desgaste do anel e da camisa é da ordem de micrômetros, ou seja, analisando a Figura 52b) com os dados de desgaste obtidos no trabalho de Santos Filho (Santos Filho, 2013), pode-se concluir que baixos coeficientes de desgaste estão relacionados a baixos valores críticos de desgaste. Portanto, são necessárias melhorias tanto nos anéis quanto nas camisas para atender as solicitações crescentes neste sistema.

A diferença entre o contato hertziano elipsoidal a seco estático e o contato elasto-hidrodinâmico durante o deslizamento, pode ser acompanhada na Figura 54. Os corpos em contato na presença de um lubrificante entram em movimento, formando um filme hidrodinâmico entre as superfícies. A elevada pressão e o efeito do lubrificante associado ao movimento do rolamento resultam no aumento da área de contato que, devido às deformações elásticas e o aumento da viscosidade do lubrificante, tornam as superfícies planas e paralelas. A pressão na entrada é menor em relação ao contato a seco e a espessura do filme na região central é $H_{c}$. Na saída ocorre uma diminuição abrupta da viscosidade, originando uma constrição entre as superfícies, em razão da manutenção do fluxo constante, reduzindo a espessura do filme para $h_{\min }$. Nesta região ocorre um pico de tensão, que geralmente é maior que a pressão máxima de contato [51]. 


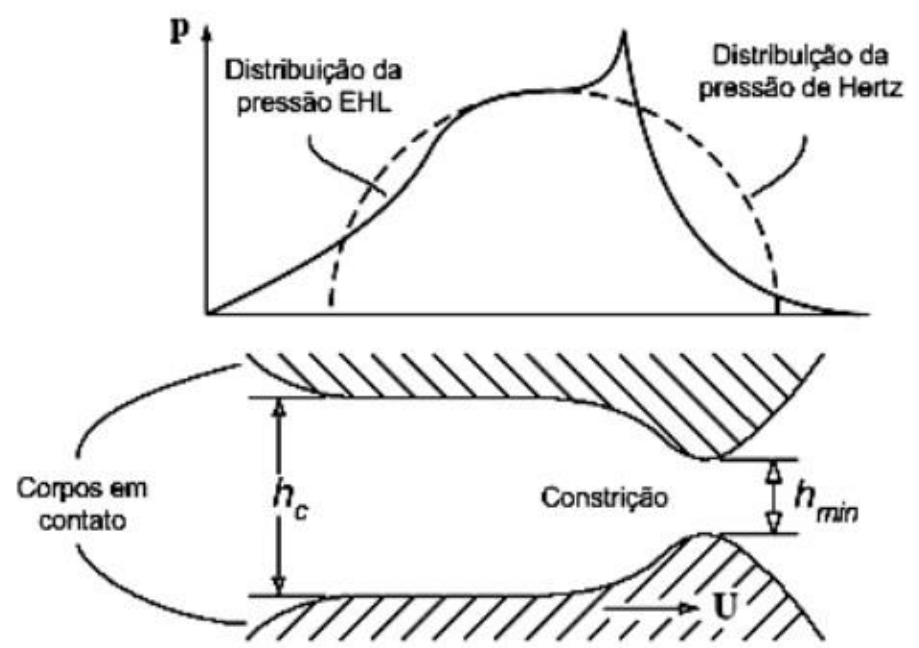

Figura 54 - Distribuição de pressão em regime elasto-hidrodinâmico (EHL) [51].

\subsubsection{Running-in}

O termo em inglês "running-in" [57] é muito usado no campo da tribologia e existem diferentes significados para ele; pode se referir ao procedimento operacional usado para otimizar o atrito ou a performance de desgaste para uma condição de superfície; como também se referir a mudanças no atrito e/ou desgaste que ocorre antes do tribossistema atingir o estado estacionário após a partida.

O estado estacionário em tribologia é a condição de um determinado tribosistema em que o coeficiente de atrito cinético médio, taxa de desgaste, e/ou outros parâmetros especificados tenham atingido e mantido um nível relativamente constante [57,58].

Running-in em tribologia é correlacionado aos processos que ocorrem antes do estado estacionário, quando duas ou mais superfícies sólidas são reunidas sob carga e com movimentos relativos uns em relação ao outro. Este é normalmente acompanhado por alterações no coeficiente de atrito nominal e/ ou taxa de desgaste $[57,58]$.

Abbott e Firestone associaram o running-in a mudanças na microgeometria das superfícies em contato. Quando duas superfícies recém-usinadas são colocados em contato, somente os picos mais altos de irregularidades se tocam e a área de contato real é muito pequena. Se as superfícies são colocadas sob carga, ou adaptada de outra forma, as irregularidades mais altas são retiradas gradualmente e a área real de contato aumenta. No início, o desgaste é muito rápido, mas diminui à medida que 
aumenta a área de contato $[20,51,57,58]$.

A Figura 55 mostra esquematicamente a redução de atrito e rugosidade em função do tempo ou distância de deslizamento em corpos sob operações operacionais constantes. A fase 1 (Figura 55) do regime de running-in, ocorre uma diminuição significativa da rugosidade da superfície e o coeficiente de atrito. Na fase 2 de runningin, o contato repetitivo provoca o endurecimento do material, resultando no aumento da microdureza e tensões residuais na superfície. Durante esta fase, a redução do coeficiente de atrito e rugosidade da superfície é limitada. É desejável, para os componentes da máquina, operar o maior tempo possível no regime estacionário para aumentar o tempo de vida do equipamento [58].

Durante o running-in o sistema tende a um estado de equilíbrio em todo o tribossistema como: pressão de contato, rugosidade da superfície, a camada de interface, o estabelecimento de uma película de lubrificação eficaz na interface. Esses ajustes podem abranger conformidade da superfície, formação de película de óxido, de transferência de material, produtos de reação lubrificante, microestrutura, podendo ocorrer transformação de fase e na subsuperfície reorientação microestrutural.

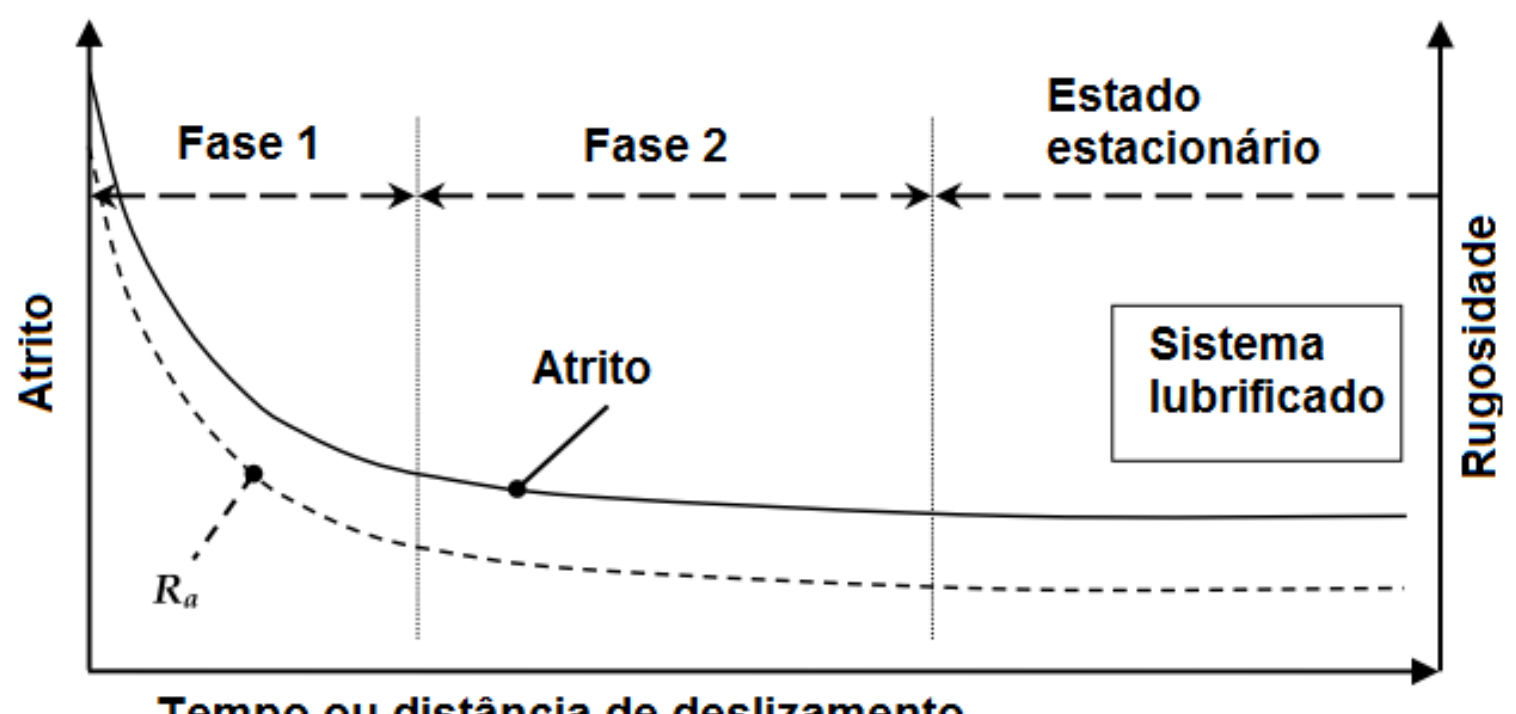

Figura 55 - Mudança do coeficiente de atrito e rugosidade em função do tempo ou distância de deslizamento em corpos sob condições de operação constante [58] 


\subsubsection{Relação entre microestrutura e tribologia}

A modificação na microestrutura da superfície em movimento relativo pode ser uma alternativa viável na redução do coeficiente de atrito. As possibilidades de modificação da superfície englobam tratamentos térmicos, texturização a laser, refusão da superfície, etc.

Prasad [59] estudou o comportamento de diferentes matrizes de ferro fundido em testes a seco; lubrificado com óleo (SAE40); óleo $+5 \%$ de grafita; e óleo $+10 \%$ de grafita. Os resultados mostraram que em quase todos os testes, a superfície de ferro fundido cinzento obteve desempenho melhor em relação ao ferro fundido nodular de matriz perlítica.

Particularmente, o endurecimento do material é uma possível prática de redução do coeficiente de atrito e do desgaste, tendo em vista a melhoria na capacidade da superfície sustentar uma camada de óxido, evitando o contato metal/metal. Zimba et al. [9] estudaram em um equipamento de desgaste por deslizamento reciprocating sem lubrificação (em uma faixa de cargas entre 40 e 140 N) a influência do endurecimento da matriz de um ferro nodular proporcionado pelo tratamento térmico de austêmpera $\left(325-375^{\circ} \mathrm{C}\right)$, os resultados mostraram a redução do coeficiente de atrito em 10 vezes. A melhora nas propriedades tribológicas foi atribuída ao endurecimento da matriz, lubrificação sólida (nódulos de grafita) e transformação da austenita retida em martensita.

A morfologia da grafita da superfície também influencia em ensaios de desgaste. Neves [52], ensaiou dois tipos ferros fundidos diferentes, um cinzento e outro nodular. Os ferros fundidos foram tratados a $900{ }^{\circ} \mathrm{C}$ durante $45 \mathrm{~min}$. e temperados em sal (aquecido a $160{ }^{\circ} \mathrm{C}$ ). Em seguida foram revenidos a $200{ }^{\circ} \mathrm{C}$ durante 1 hora. A vida em fadiga do ferro nodular foi 16 vezes maior que a vida do ferro fundido cinzento. Segundo o autor, o ferro fundido cinzento oferece um caminho mais curto a propagação de trincas, devido à maior capacidade de concentração de tensões da grafita de morfologia lamelar.

A distância média entre lamelas de grafita em ferro fundido cinzento influencia no desgaste por deslizamento. TAKEUCHI [60] verificou que a diminuição dos espaçamentos entre veios de grafita aumentam a resistência ao desgate em codições normais, assim como, sobre condições de adesão.

Outro parâmetro que deve ser considerado em testes de desgaste é a relação 
entre o tamanho do diâmetro de contato e o diâmetro dos nódulos de grafita. Dommarco et al. $[61,62]$ estudaram em testes de fadiga de contato de rolamento a relação entre o tamanho do diâmetro de contato (Dc) e o diâmetro dos nódulos de grafita (Dn) em ferros fundidos nodulares. Os autores verificaram que quanto menor a relação Dc/Dn, menor o desempenho em vida de fadiga de contato de rolamento. Eles associaram este resultado ao pico de tensão gerado nas bordas da cavidade do nódulo de grafita, contribuindo para a nucleação da trinca.

O acabamento da superfície em contato dos materiais também interfere nos ensaios de desgaste. Brunetti et al. [63,64] mostraram que a vida em fadiga de rolamento em ferros fundidos nodular austemperados (ADIs) aumentam em superfícies polidas ensaiadas sob as mesmas condições. O ciclo de vida neste tipo de superfície foi $89 \%$ maior do que em superfícies retificadas. Os autores apontaram que a grafita na superfície rugosa pode-se apresentar quebrada ou parcialmente quebrada, apresentando-se como um maior concentrador de tensões. Por conseguinte, ocasionaria a redução do tempo de vida na fadiga de contato de rolamento [64]. Brunetti [63] e Neves [52] também observaram que os lascamentos ocorrem sempre em regiões preferenciais na trilha de rolamento, onde as esferas de rolamento percorreram nódulos maiores de grafita.

A superfície pode ser modificada utilizando lasers, como foi mencionado anteriormente. Tomanik [16] modificou a superfície em cilindros brunidos de motores a diesel com diferentes tipos de lasers. Os testes de desgaste foram efetuados em um equipamento de reciprocating, onde o coeficiente de atrito e o desgaste entre o anel e o cilindro foram analisados. Os corpos de prova nos testes de desgaste foram avaliados durante 4 horas, nos quais houve aumento de carga e adição de partículas duras para acelerar a taxa de desgaste. O melhor resultado de desgaste da camisa e do anel após $0,5 \mathrm{~h}$ foi obtido com as superfícies tratadas com lasers UV.

XIA [65] modificou a superfície usando tratamentos a laser em uma matriz de ferro fundido nodular, usando como lubrificante líquidos parafínicos contendo vários aditivos. Os testes de desgaste por deslizamento foram realizados em um OPTIMOL SRV-4 na configuração esfera/disco, amplitude de $1 \mathrm{~mm}, 20 \mathrm{~Hz}, 100 \mathrm{~N}$, usando uma esfera de AISI52100. Os maiores coeficientes de atrito medidos foram usando o líquido parafínico, 0,16-0,14; os menores coeficientes de atrito ficou na faixa de 0,095 - 0.075 usando o líquido parafínico + aditivos.

Alternativas como a introdução de vazios na superfície também podem auxiliar 
na redução do coeficiente de atrito. Grabon et al. [14], modificou a superfície de cilindros de ferro fundido cinzento com cavidades de profundidade de 5 um e diâmetros variando entre 0,15 - 0,2 $\mathrm{mm}$, cobrindo $13 \%$ da superfície, a partir de técnicas de polimento. A carga normal utilizada nos testes de reciprocating variaram de $50-300$ $\mathrm{N}$ e velocidades de deslizamento foram variadas entre $0,44-0,88 \mathrm{~m} / \mathrm{s}$. A presença das cavidades melhorou o coeficiente de atrito no regime hidrodinâmico, ao servirem como retentores de lubrificante.

FENG [66] estudou a influencia de compostos orgânicos como Mo e ZnDTP em diferentes concentrações no lubrificante PAO, usando o equipamento OPTIMOL SRV4. A carga utilizada para os testes foi de $50 \mathrm{~N}$ e a velocidade de deslizamento foi de $0,04,0,08,0,12,0,16$ e $0,2 \mathrm{~m} / \mathrm{s}$, amplitude de $1 \mathrm{~mm}$ em temperatura ambiente; a configuração foi do tipo esfera/disco, esfera de AISI52100 e disco de ferro fundido cinzento. 


\subsection{MATERIAIS E MÉTODOS}

O fluxograma (Figura 56) apresenta a metodologia realizada neste trabalho

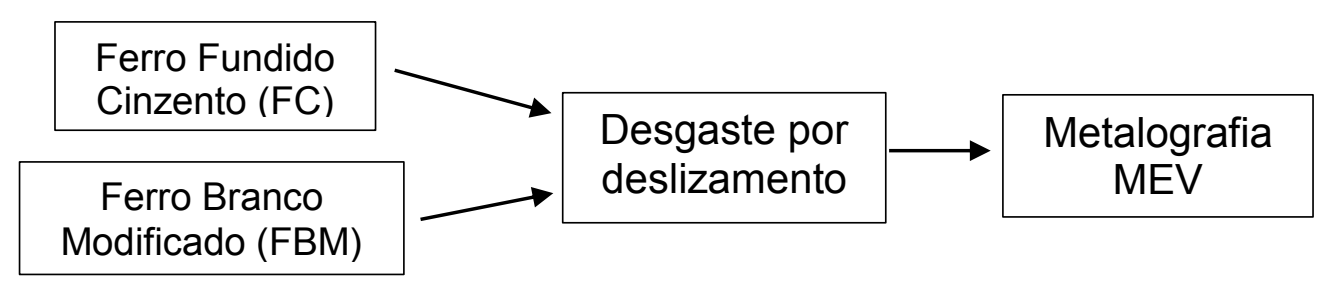

Figura 56 - Fluxograma utilizado no trabalho.

Amostras de ferro cinzento fornecidos pela TUPY S.A. foram obtidas de cilindros de blocos de ferro cinzento cortados e aplainados; o ferro branco coquilhado com composição química de um ferro fundido cinzento convencional fornecido pela TUPY S.A. foi submetido a tratamento em forno a vácuo a $900^{\circ} \mathrm{C}$ durante 20 minutos, resfriados em óleo e revenidos a $200{ }^{\circ} \mathrm{C}$ durante 30 minutos.

As amostras de ferro fundido cinzento (FC) e ferro branco modificado (FBM) foram ensaiados em testes de desgaste por deslizamento. A configuração do contracorpo e corpo foi do tipo anel/plano, onde o contra-corpo utilizado foi um anel de aço inox 403 com superfície nitretada produzido pela Mahle, correspondente a um anel de segmento de motor automotivo; enquanto o corpo foi produzido a partir de amostras de FC no estado como recebido e o FBM tratado termicamente segundo o procedimento descrito acima. Os corpos de prova foram cortados com as dimensões de $20 \times 12 \times 4 \mathrm{~mm}^{3}$ e as superfícies a serem ensaiadas foram retificadas em um rebolo AA60K6K, cujas características são sumarizadas na Tabela 10. A velocidade de avanço foi $0,5 \mathrm{~mm}$ e remoção da superfície de 12 centésimos. As amostras passaram no mesmo rebolo seguindo os mesmos parâmetros de retífica.

A rugosidade da superfície dos corpos de prova foi medida antes do ensaio tribológico no perfilômetro óptico modelo Taylor Hobson CCI-MP no Laboratório de Fenômenos de Superfície do Departamento de Engenharia Mecânica da Escola Politécnica da Universidade de São Paulo. 
Tabela 10 - Característica do rebolo.

\begin{tabular}{|c|c|}
\hline Parâmetro & Característica \\
\hline AA & Óxido de Alumínio \\
\hline 60 & Granulagem média \\
\hline Aglutinante V & Vitrificado \\
\hline Dureza K & Macio \\
\hline Estrutura de poros 6 & Média \\
\hline
\end{tabular}

Os ensaios de desgaste por deslizamento foram realizados no equipamento OPTIMOL SRV-4 presente no Laboratório de Fenômenos de Superfície do Departamento de Engenharia Mecânica da Escola Politécnica da Universidade de São Paulo. A amostra e o anel foram fixados em seus respectivos aparatos do equipamento tal qual indicado na Figura 57a e posicionados dentro da câmara de testes como mostrado na Figura 57b. Em todos os testes realizados neste equipamento foi convencionado manter o movimento reciprocante perpendicular às marcas de usinagem, como mostra a Figura 58 , onde a base é fixa em relação ao movimento oscilatório do anel.
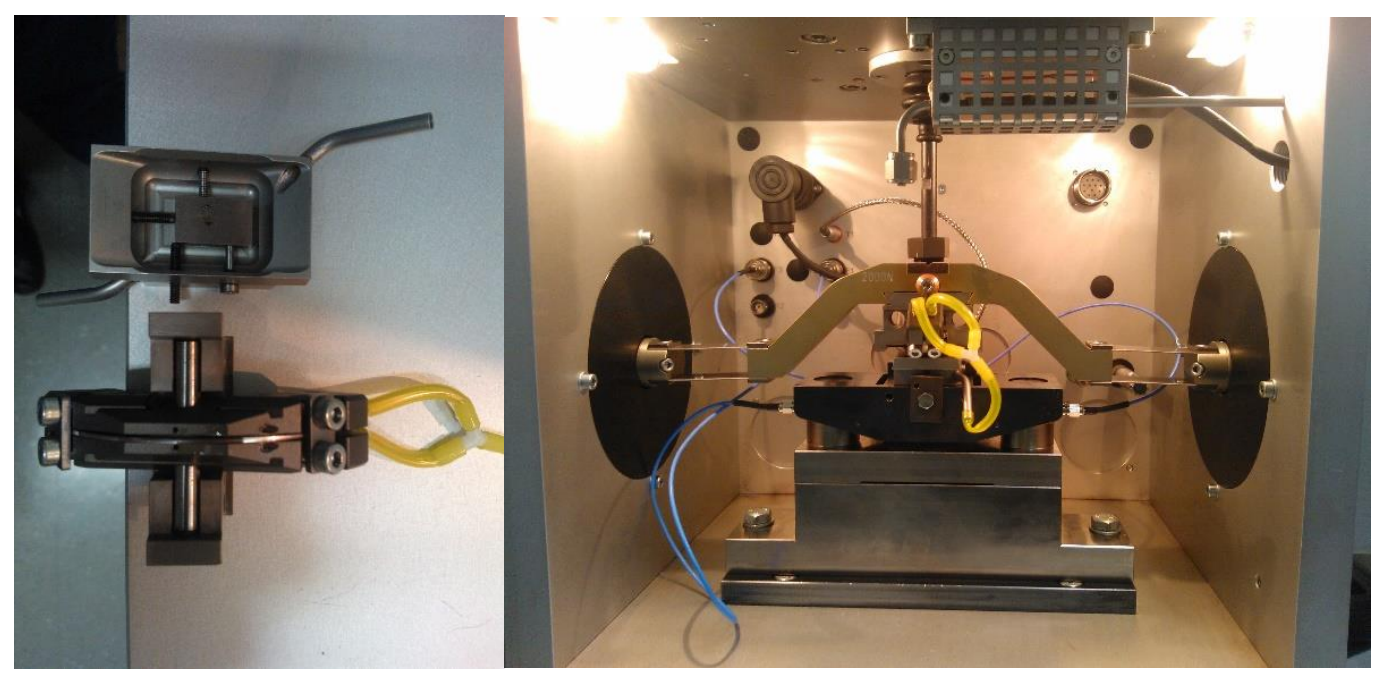

Figura 57 - (a) anel e amostra fixados nos aparatos do OPTIMOL. (b) amostra posicionada na câmara de teste. 


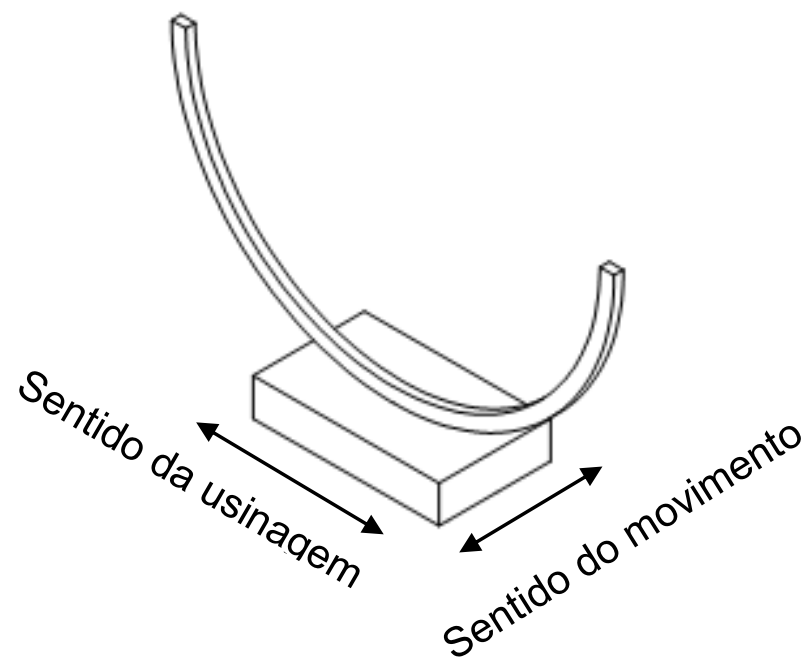

Figura 58 - Esquema mostrando a configuração contra-corpo (anel) e corpo (amostra)

Conforme apontado anteriormente na revisão bibliográfica, o cilindro durante o funcionamento do motor inclui uma combinação de lubrificação limítrofe e elastrohidrodinâmica e, por este motivo, as amostras foram submetidas nas condições de regime lubrificado e seco.

Nas amostras em regime lubrificado, antes do posicionamento do corpo e contra-corpo na câmara de teste, a interface do tribossistema foi primeiramente embebida em óleo e em seguida o corpo de prova foi totalmente submerso no mesmo óleo. Os parâmetros utilizados no equipamento foram: pré-carga e carga de $50 \mathrm{~N}$; amplitude do movimento reciprocante de 2,5 mm; frequência oscilação de $20 \mathrm{~Hz}$; temperatura ambiente e tempo uma hora. O tribossistema estudado foi anel, óleo lubrificante e amostra. O óleo lubrificante utilizado nos testes foi o SpectraSyn 8 (PAO), óleo sem aditivos e baixa viscosidade em temperatura ambiente (dados de especificação segue no apêndice A).

Os parâmetros utilizados nos testes a seco foram: pré-carga e carga de $50 \mathrm{~N}$; amplitude do movimento reciprocante de 2 mm; frequência de $20 \mathrm{~Hz}$; temperatura ambiente e quinze minutos de teste. O tribossistema estudado foi anel e amostra.

Após os ensaios de desgaste por deslizamento a marca originada pelo contato entre o corpo e contra-corpo na superfície da amostra foram caracterizadas por MO, MEV, lupa estereoscópica e perfilômetro óptico. As imagens das marcas de desgaste no corpo e contra-corpo foram medidas no software ImageJ (comprimento e largura) e a profundidade no software do perfilômetro óptico Taylor Hobson, seguindo o mesmo procedimento utilizado para caracterizar a rugosidade do material antes do ensaio. 


\subsection{RESULTADOS E DISCUSSÃO}

\subsubsection{Caracterização da superfície antes do teste}

\subsubsection{Caracterização do contra-corpo (anel)}

Como o foco do trabalho não foi o estudo do anel realizou-se a medida da espessura da superfície nitretada e a medição de durezas.

O material do anel trata-se de um aço inox 403 com superfície nitretada com espessura de $17 \mu \mathrm{m}$ de profundidade, como pode ser visualizado na imagem usando MEV (Figura 59).

A dureza média da superfície é de $695 \pm 21$ HV e a matriz 413,4 \pm 11 HV (Tabela 11), onde foram realizadas 10 medições aleatórias em cada região analisada.

\subsubsection{Caracterização do corpo (camisa: FC e FBM)}

As superfícies do FC e do FBM foram preparadas metalograficamente e atacadas com Nital $2 \%$.

O FC apresenta matriz perlítica com grafita lamelar (Figura 60a) e dureza média de $\mathrm{HV}_{0,3} 211 \pm 13$

O FBM apresenta matriz de martensita revenida, grafita, sulfeto de manganês e cementita com cantos arredondados (Figura 60b); a dureza média é $\mathrm{HV}_{0,3} 720 \pm 57$. A comparação desta estrutura com as amostras maleabilizadas no dilatômetro por tempos equivalentes revelaram que a dissolução/esferoidização dos carbonetos eutéticos está menos avançada nas amostras FBM. Isto provavelmente se deve ao fato do aquecimento ser mais lento, uma vez que as amostras estavam em forno a vácuo. Assim, a estrutura do FBM é aproximadamente equivalente à de uma amostra tratada por 10 min no dilatômetro. 


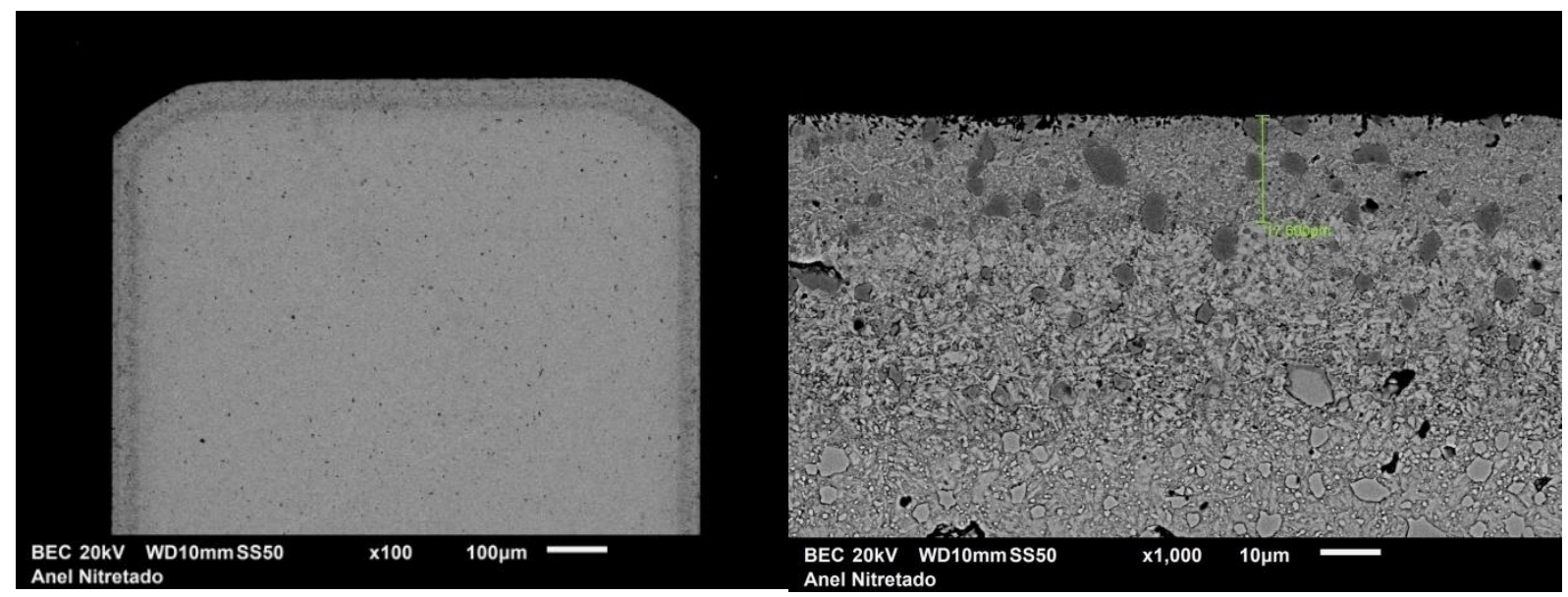

(a)

(b)

Figura 59 - Caracterização do anel: (a) visão geral apresentando a camada nitretada (mais escura), (b) maior detalhe apresentando a espessura da camada nitretada (cerca de $17 \mu \mathrm{m}$ ).

Tabela 11 - Resultados das medições de dureza do anel.

\begin{tabular}{|c|c|c|}
\hline \multicolumn{3}{|c|}{ Anel de aço inoxidável nitretado } \\
\hline Medição & Centro & Superfície \\
\hline $\mathbf{1}$ & 417,6 & 677,3 \\
\hline $\mathbf{2}$ & 426,1 & 695,0 \\
\hline $\mathbf{3}$ & 403,9 & 654,7 \\
\hline $\mathbf{4}$ & 406,6 & 701,0 \\
\hline $\mathbf{5}$ & 434,9 & 696,0 \\
\hline $\mathbf{6}$ & 401,3 & 707,2 \\
\hline $\mathbf{7}$ & 412,0 & 713,4 \\
\hline $\mathbf{8}$ & 414,8 & 654,7 \\
\hline $\mathbf{9}$ & 396,0 & 683,1 \\
\hline $\mathbf{1 0}$ & 417,6 & 707,2 \\
\hline Média & $\mathbf{4 1 3 , 4}$ & $\mathbf{6 9 5 , 5}$ \\
\hline Desvio & $\mathbf{1 1 , 7 7}$ & $\mathbf{2 1 , 1 1}$ \\
\hline Padrão & &
\end{tabular}



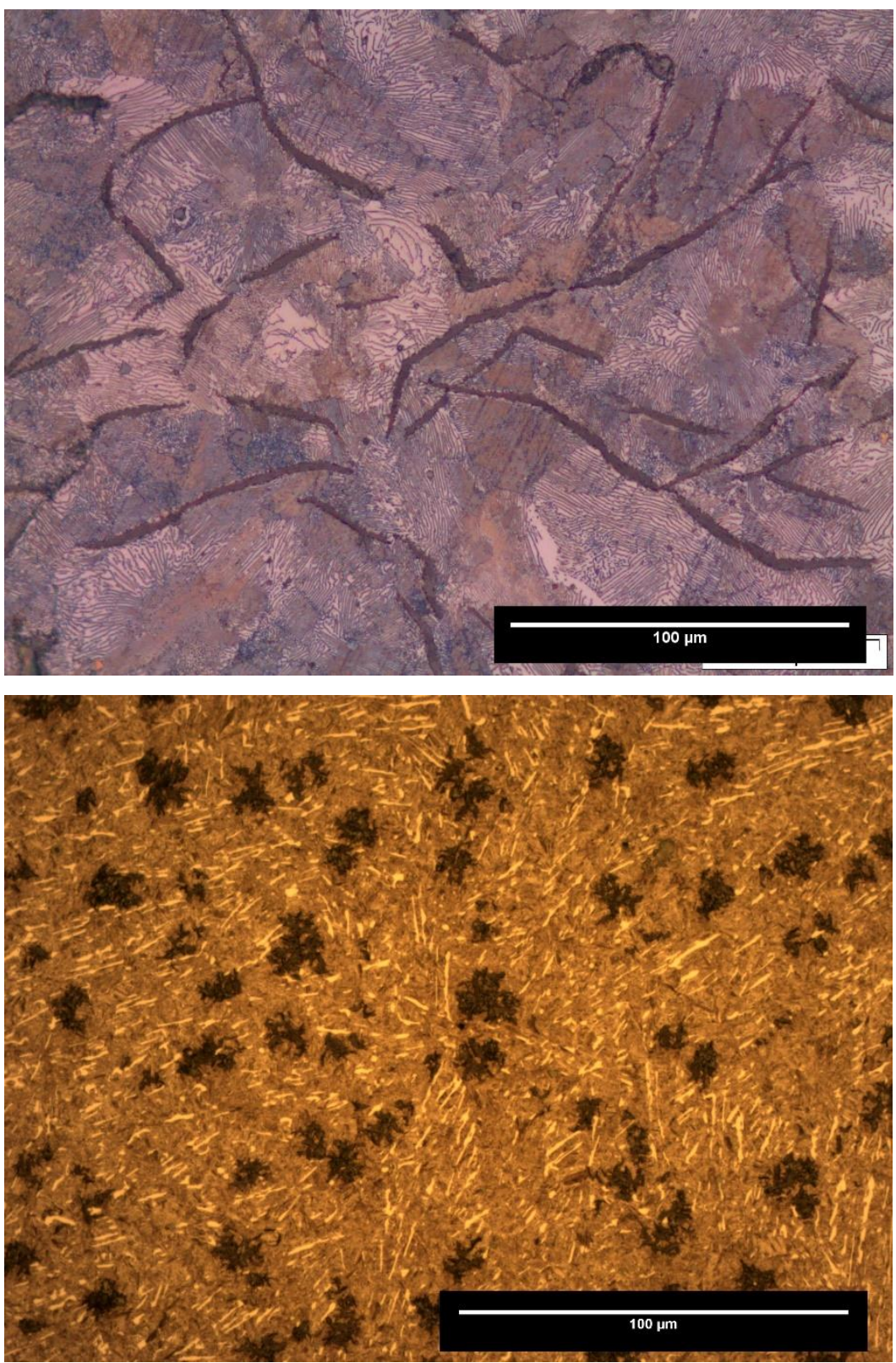

Figura 60 - FBM submetido a tratamento a $900{ }^{\circ} \mathrm{C}$ durante 20 minutos, revenimento a $200{ }^{\circ} \mathrm{C}$ durante 30 minutos, atacados com Nital $2 \%$.

\subsubsection{Medidas de rugosidade das superfícies: FC e FBM.}

A rugosidade da superfície das amostras antes dos ensaios foi medida no perfilômetro óptico e os resultados são apresentados na Tabela 12. A rugosidade média foi obtida a partir de três medições nas regiões que foram ensaiadas.

Onde: Spk: Altura reduzida dos picos

Sa: Média aritmética das alturas em módulo

Svk: Altura reduzida de bacias 
Tabela 12 - Rugosidade das superfícies antes dos ensaios de desgaste por deslizamento

\begin{tabular}{|c|c|c|}
\hline Amostra & FC & FBC \\
\hline \multirow{4}{*}{ Spk } & 0,249 & 0,254 \\
\cline { 2 - 3 } & 0,289 & 0,244 \\
\cline { 2 - 3 } & 0,245 & 0,244 \\
\hline Média & 0,261 & 0,247 \\
\hline $\begin{array}{c}\text { Desvio } \\
\text { padrão }\end{array}$ & 0,024 & 0,005 \\
\hline \multirow{2}{*}{ Sa } & 0,254 & 0,225 \\
\cline { 2 - 3 } & 0,253 & 0,241 \\
\cline { 2 - 3 } & 0,244 & 0,286 \\
\hline Média & 0,250 & 0,251 \\
\hline Desvio & 0,006 & 0,032 \\
padrão & $0,0,506$ & 0,438 \\
\hline \multirow{2}{*}{ Svk } & 0,574 & 0,553 \\
\cline { 2 - 3 } & 0,549 & 0,526 \\
\hline Média & 0,510 & 0,506 \\
\hline \multirow{2}{*}{$\begin{array}{c}\text { Desvio } \\
\text { padrão }\end{array}$} & 0,038 & 0,060 \\
\hline
\end{tabular}

Analisando os dados da Tabela 12, percebe-se que os parâmetros de rugosidade se apresentam muito próximos e podem ser considerados estatisticamente iguais, de forma que os resultados dos testes podem ser condicionados apenas às modificações estruturais originadas nos tratamentos térmicos.

\subsubsection{Ensaio de desgaste: regime lubrificado}

O gráfico do coeficiente de atrito versus tempo com todos os testes realizados no FC e FBM são apresentados respectivamente na Figura 61 e Figura 62. As cinco medições do FC no gráfico apresentado na Figura 61 são identificados por FC1, FC2, FC3, FC4 e FC5, o mesmo procedimento foi feito para identificar as cinco medições realizadas no FBM (Figura 62). A média de cinco medidas de coeficiente de atrito de amostras de FC e de FBM realizados no OPTIMOL em regime lubrificado corresponde a Figura 63. Analisando os resultados dos experimentos nos dois materiais, percebese que a amostra de FC apresenta valores de coeficiente de atrito, instantes iniciais dos ensaios (período denominado running-in), menores do que são observados na 
amostra FBM. Adicionalmente, o tempo necessário para que o regime atinja o regime estacionário, isto é, o tempo de remoção dos picos de rugosidade mais altos, é menor para a amostra FBM. No regime estacionário, por outro lado, considerando o desvio padrão dos materias testados o coeficiente de atrito é praticamente igual, como pode ser observado na Figura 63.

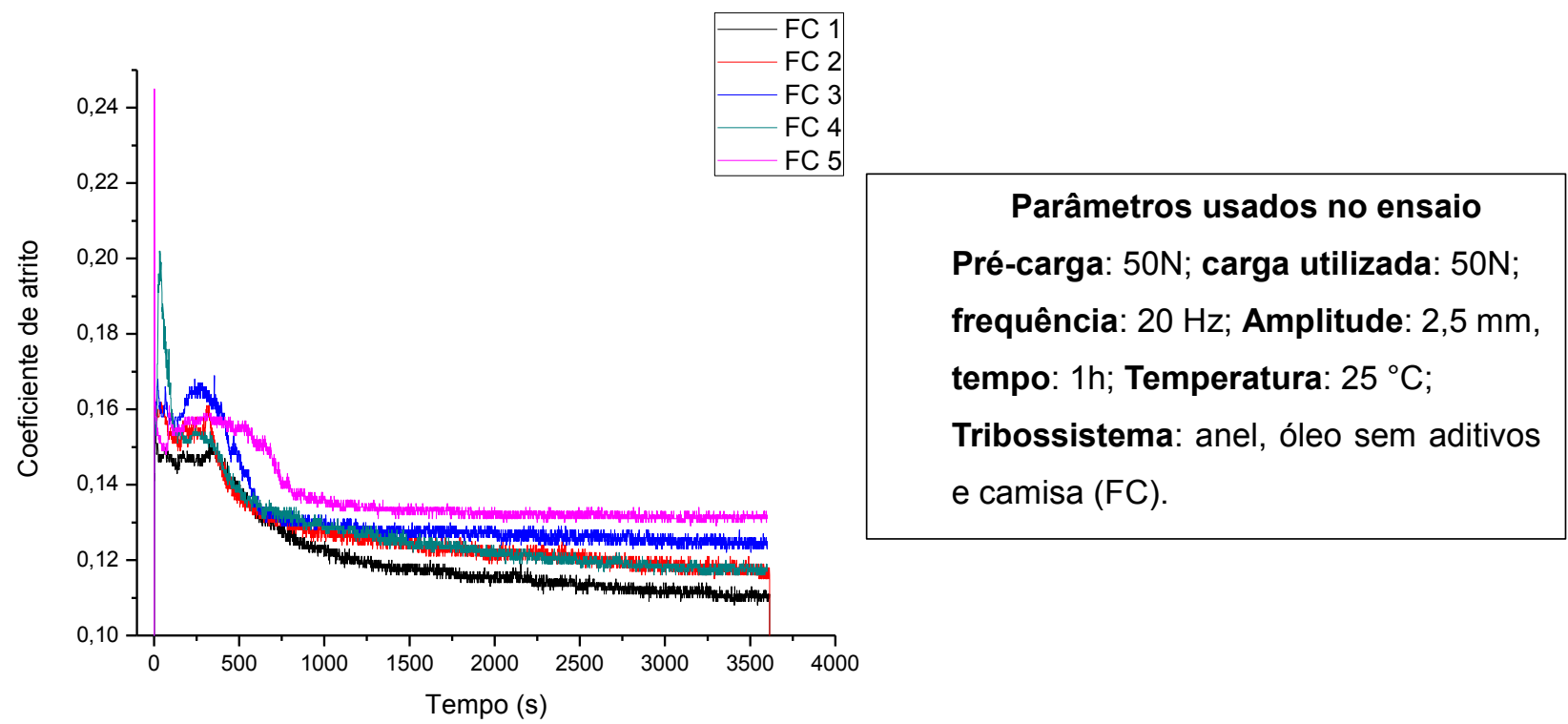

Figura 61 - Curva de atrito por deslizamento das amostras de FC em regime lubrificado.

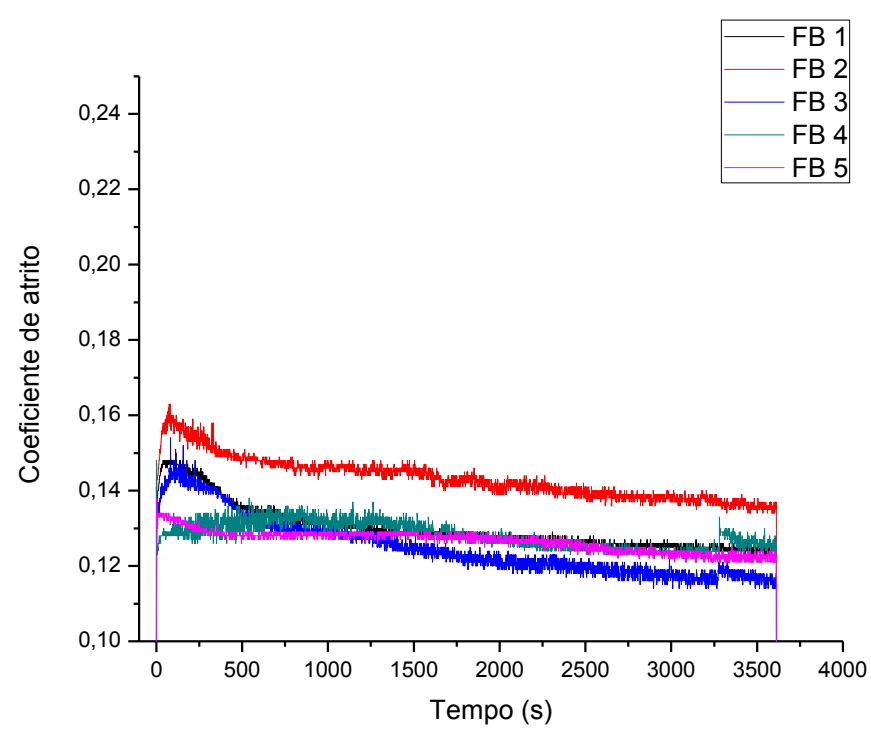

Parâmetros usados no ensaio

Pré-carga: $50 \mathrm{~N}$; carga utilizada: $50 \mathrm{~N}$;

frequência: $20 \mathrm{~Hz}$; Amplitude: $2,5 \mathrm{~mm}$, tempo: $1 \mathrm{~h}$; Temperatura: $25^{\circ} \mathrm{C}$;

Tribossistema: anel, óleo sem aditivos e camisa (FBM).

Figura 62 - Curva de atrito por deslizamento das amostras de FBM em regime lubrificado. 


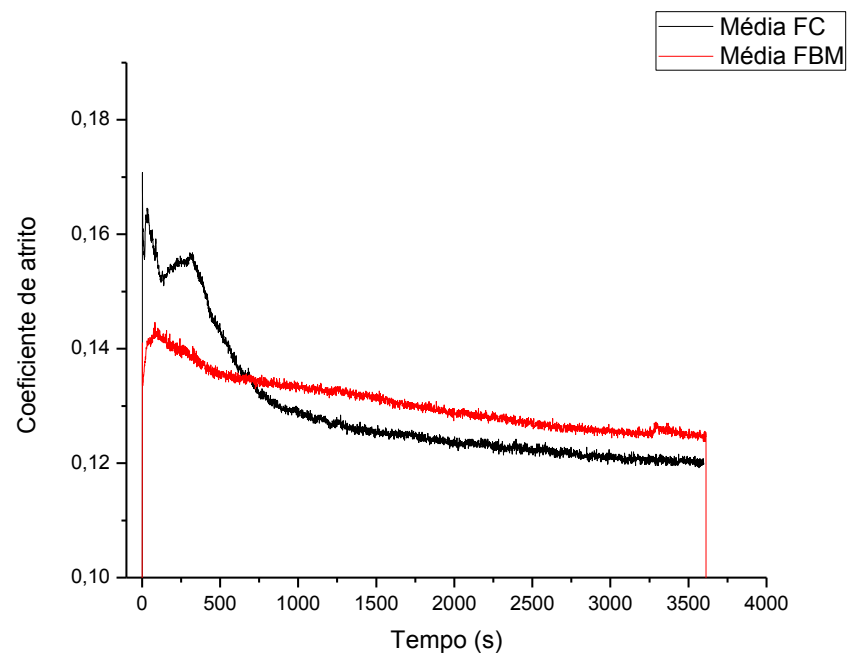

Parâmetros usados no ensaio Pré-carga: $50 \mathrm{~N}$; carga utilizada: $50 \mathrm{~N}$; frequência: $20 \mathrm{~Hz}$; Amplitude: $2,5 \mathrm{~mm}$, tempo: $1 \mathrm{~h}$; Temperatura: $25^{\circ} \mathrm{C}$;

Tribossistema: anel, óleo sem aditivos e camisa (FC e FBM).

Figura 63 - Curva de atrito por deslizamento (média de cinco medidas) das amostras de FC e FBM em regime lubrificado.

Essas diferenças estão certamente associadas à modificação da superfície usando tratamentos térmicos, uma vez que as condições topográficas de ambos os materiais foram mantidas idênticas. A dureza do ferro fundido cinzento é de $H V_{0,3} 211$ \pm 13 , enquanto a dureza do ferro branco modificado é de $H \bigvee_{0,3} 720 \pm 57$.

5.3.3.1 Caracterização das superfícies de desgaste após o ensaio lubrificado por MO e perfilometria óptica

As medidas de comprimento na direção perpendicular ao movimento no contra corpo (anel) e no corpo (FC e FBM) possuem aproximadamente o mesmo tamanho. As macrografias feitas na lupa estereoscópica podem ser acompanhadas na Figura 64 e Figura 65; a Figura 64a ilustra o anel que foi usado em conjunto com o corpo de FC (Figura 64b), a mesma organização foi feita na Figura 65, anel (Figura 65a) e o corpo de FBM (Figura 65b). O tamanho das marcas de desgaste no corpo e contra corpo de um mesmo teste apresentaram o mesmo tamanho. Isso pode ser verificado nas imagens Figura 64a e marca de desgaste central (Figura 64b), o mesmo acontece ao mudarmos o contra corpo, Figura 65a e Figura 65b (primeira marca de desgaste).

As marcas de desgaste no anel (Figura 64a e Figura 65a) apresentam geometria na forma de elipse, indicando que $o$ anel apresenta curvatura em relação ao raio e no sentido do movimento, ou seja, o contato entre o corpo e contra corpo é do tipo não-conforme.

As marcas de desgaste originadas no contato lubrificado entre o anel e o FBM 
são menores em relação as marcas de desgaste originadas no contato lubrificado entre o anel e o FC (sem considerar a profundidade), indicando que o FBM apresenta menos desgaste em relação ao FC.

(a)

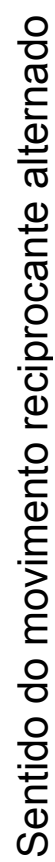

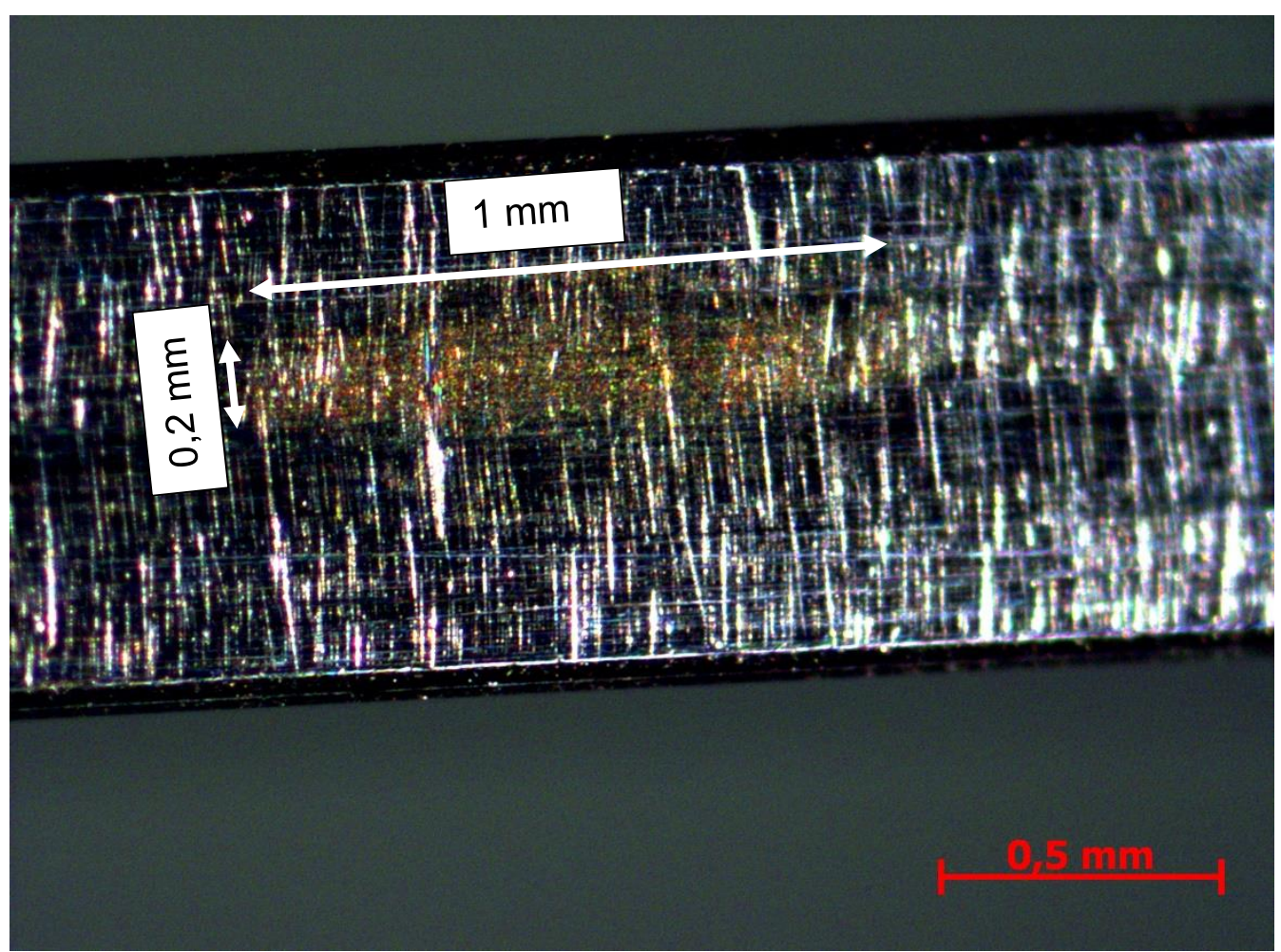

(b)

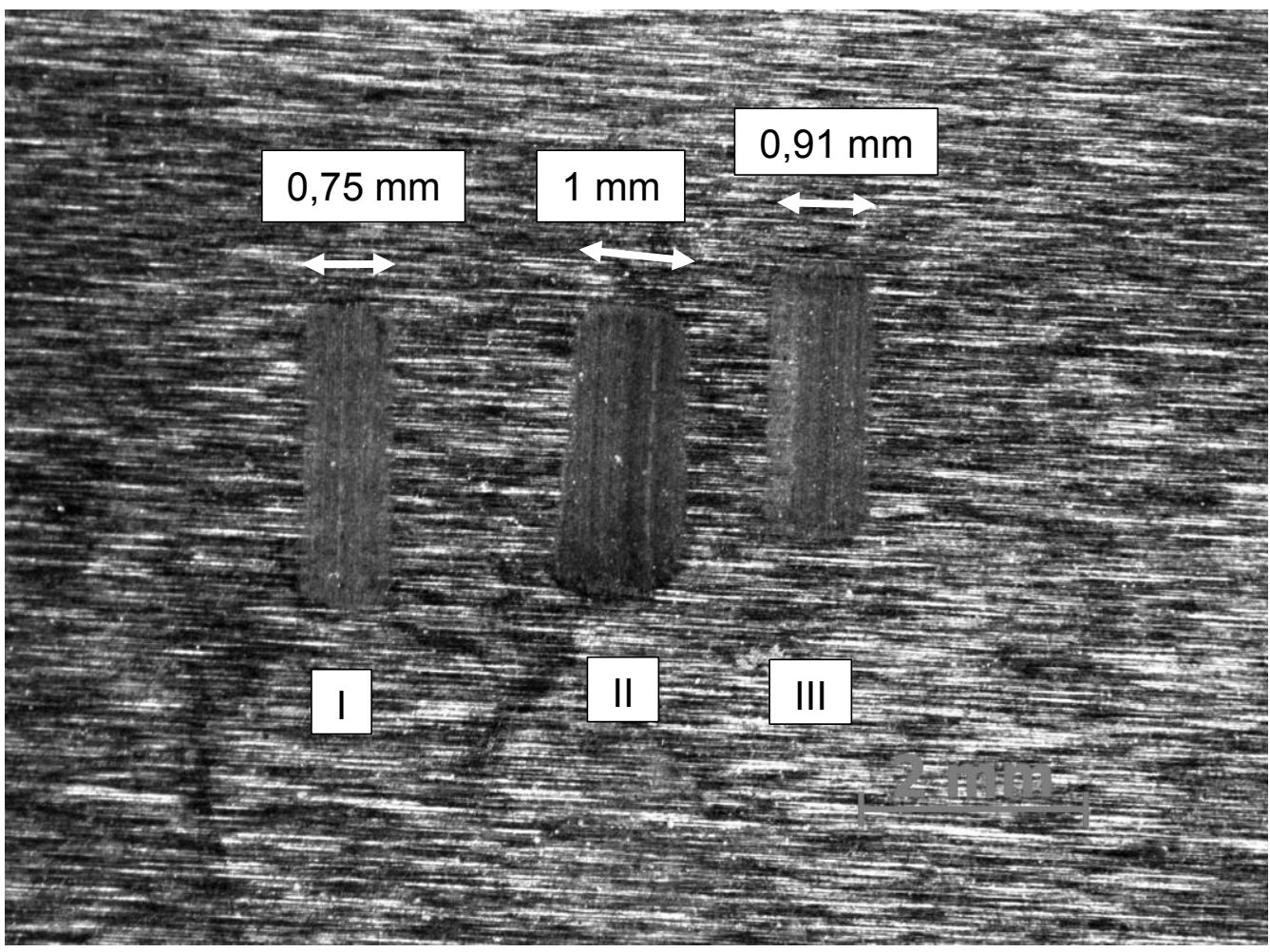

Figura 64 - marcas de desgaste no (a) anel (corpo); (b) contra-corpo (FC). 
(a)

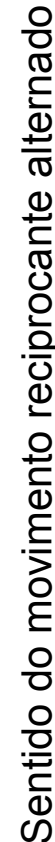

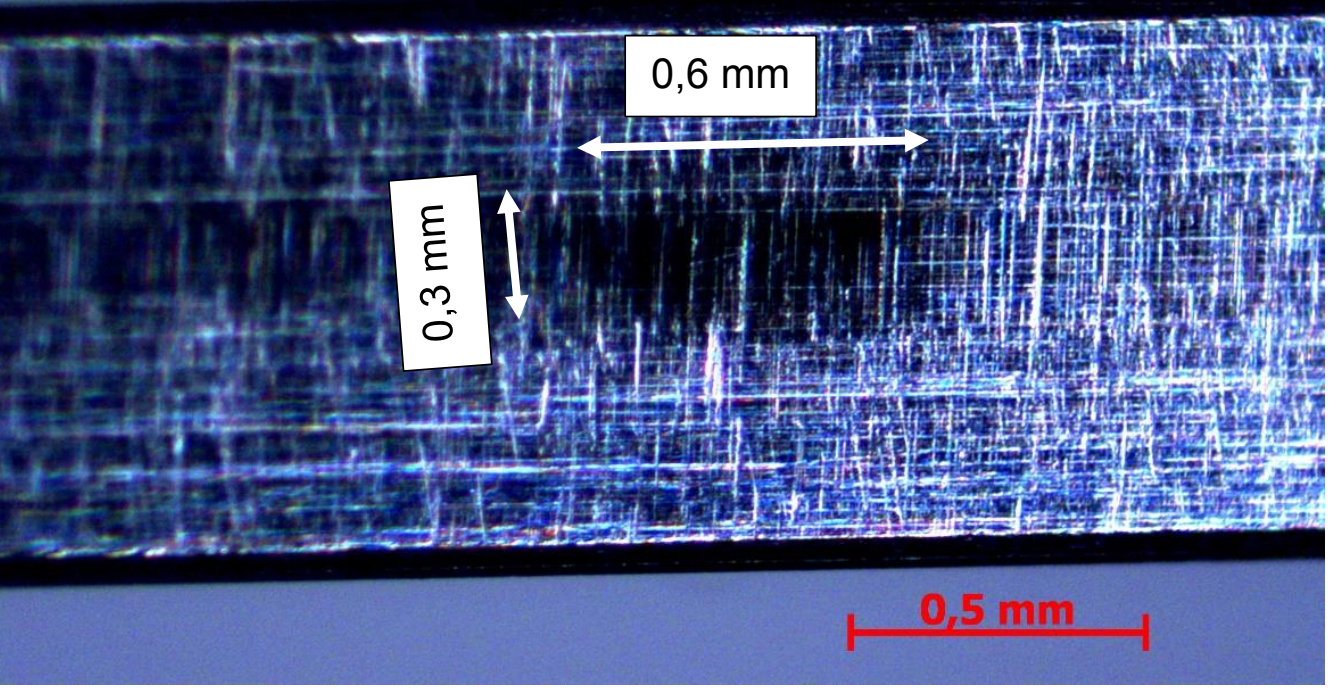

(b)

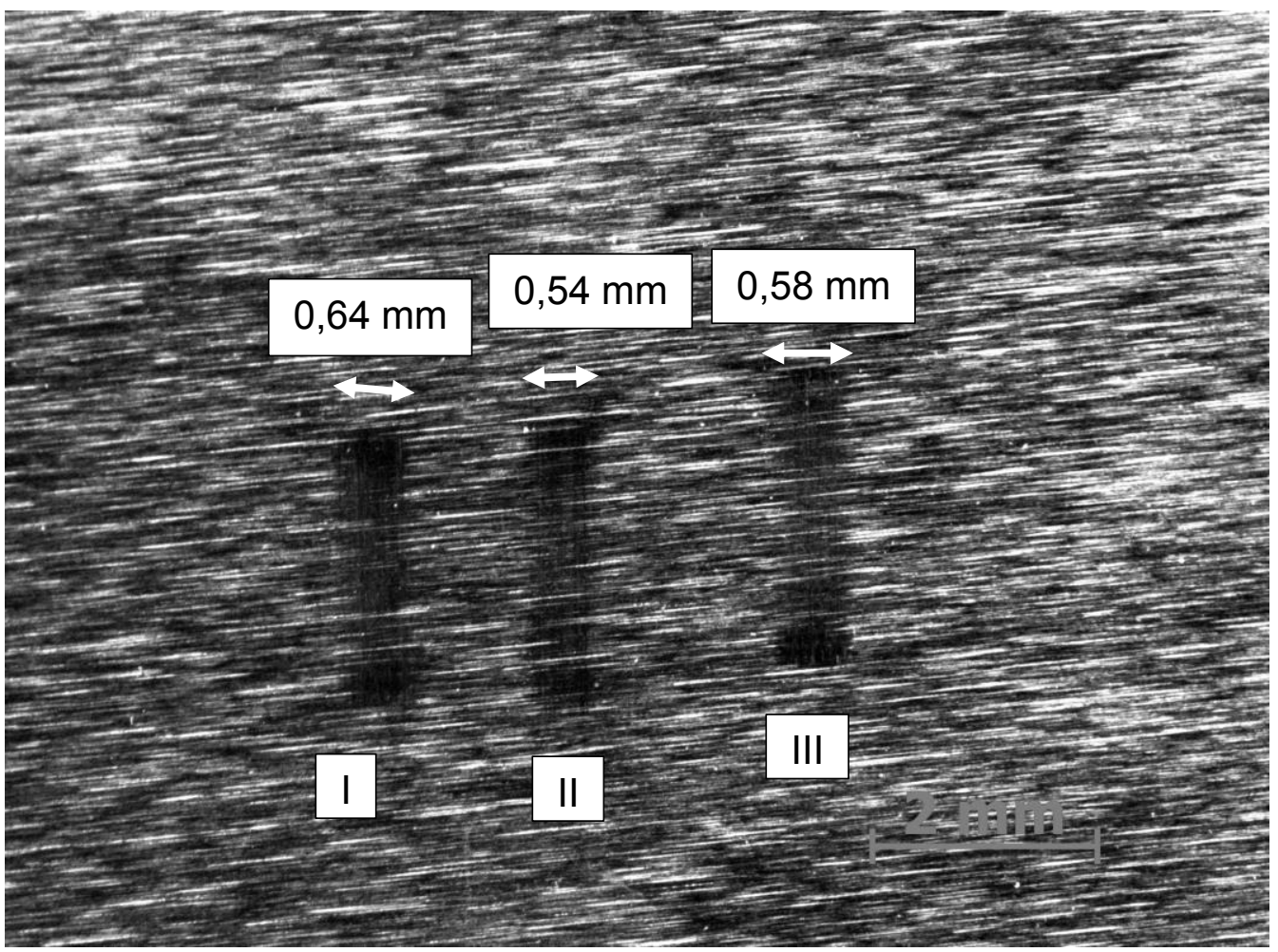

Figura 65 - marcas de desgaste no (a) anel (corpo); (b) contra-corpo (FBM). 
A análise da profundidade das marcas de desgaste foi feita por perfilometria óptica. As marcas representativas de três testes efetuados com o mesmo anel (mudando sempre a região) foram medidas no interferômetro. A amostra de FC (Figura 65a) foi medida e o mapa de profundidades apresenta-se na Figura 66. Analisando a Figura 66 (FC) percebe-se que a profundidade varia entre 2-3 $\mu \mathrm{m}$. Por sua vez, as marcas de desgaste do FB apresentaram profundidades menores do que 0,5 $\mu \mathrm{m}$.
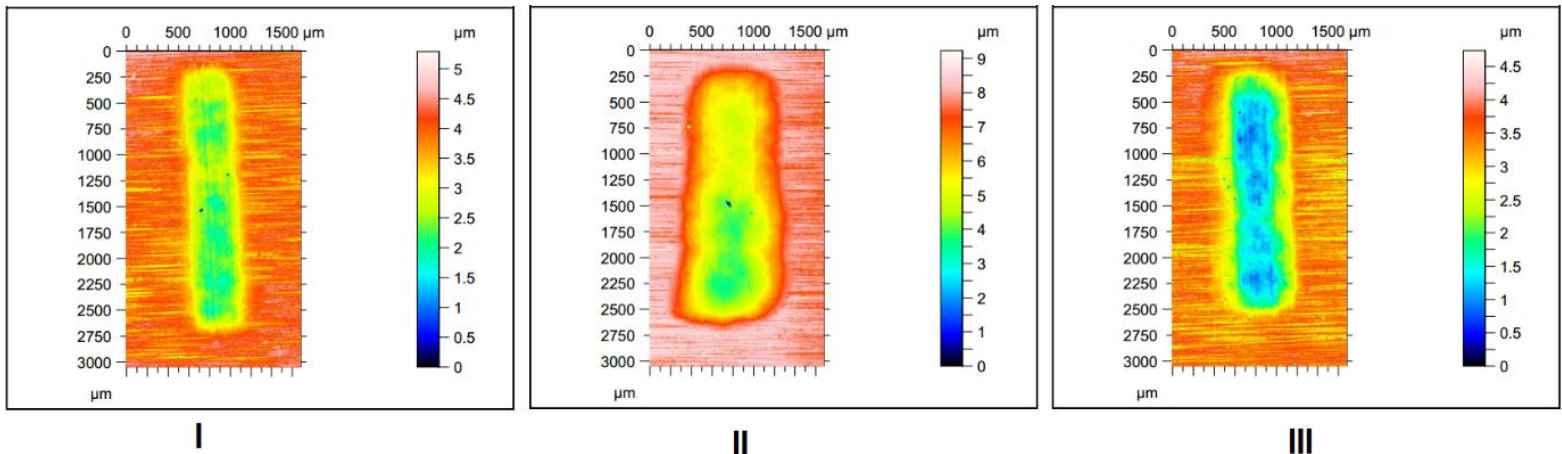

III

Figura 66 - Profundidades de desgaste lubrificado no FC obtidos no perfilômetro óptico

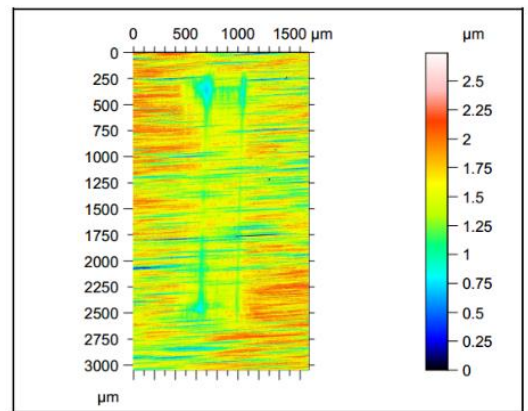

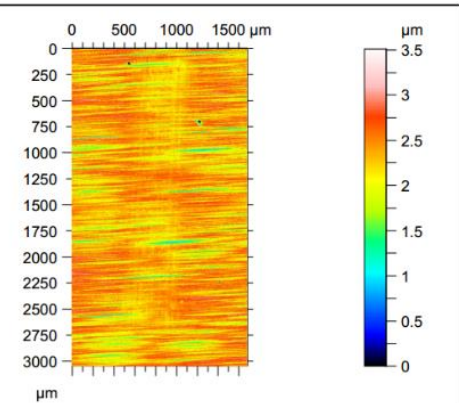

II

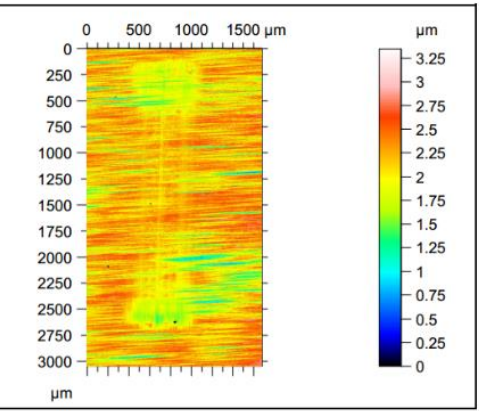

III

Figura 67 - Profundidades de desgaste lubrificado no FB obtidos no perfilômetro óptico

O perfil de profundidades medido em relação ao deslocamento do anel mostra uma certa tendência de desgaste nos extremos de curso do movimento, indiferente do tipo de corpo analisado (Figura 68 e Figura 69). A medição foi feita nas três marcas de desgaste das amostras de FC e FBM. Comparando as duas medidas, o FC apresentou maior remoção de material em relação ao FBM. A confirmação desta afirmação pode ser notada na Figura 70. 
(l)

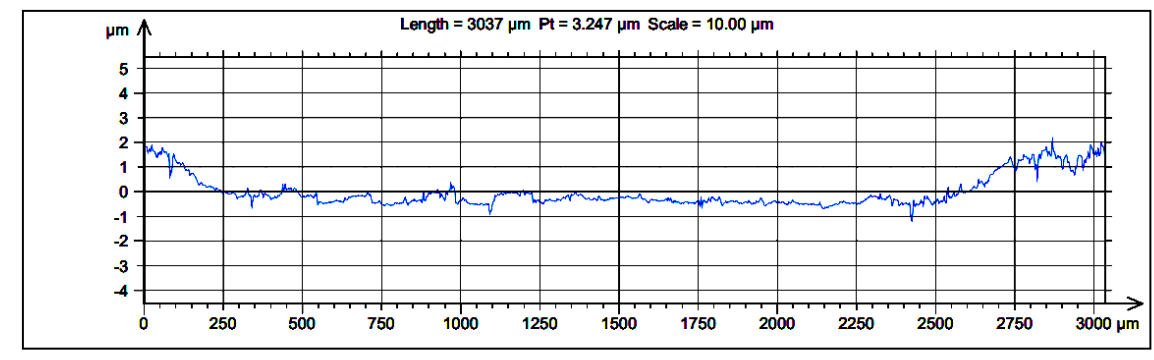

(II)
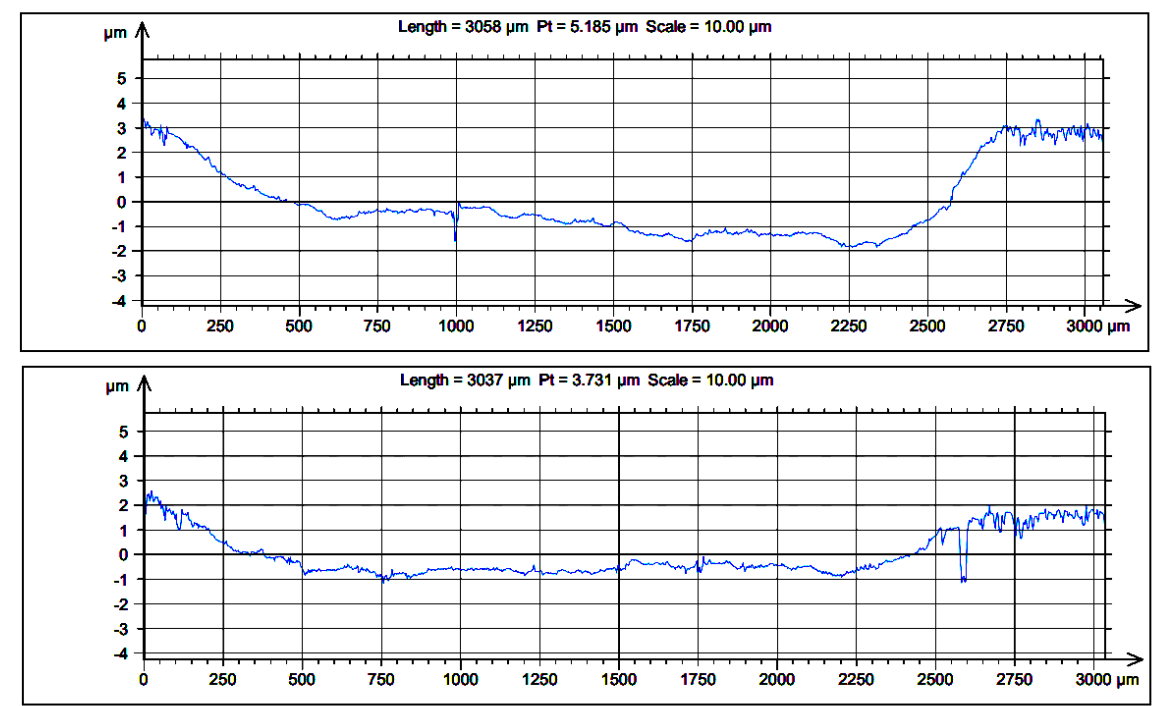

Figura 68 - Perfil de profundidades de desgaste lubrificado no FC obtidos no perfilômetro óptico (no sentido do movimento).

(I)
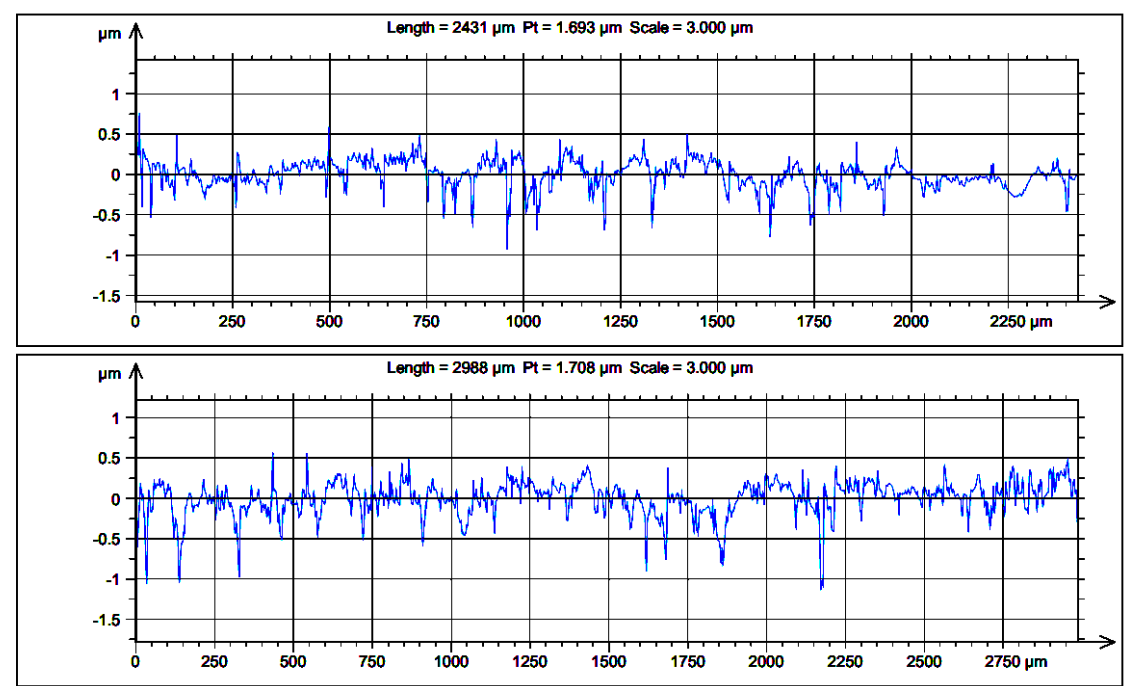

(II)

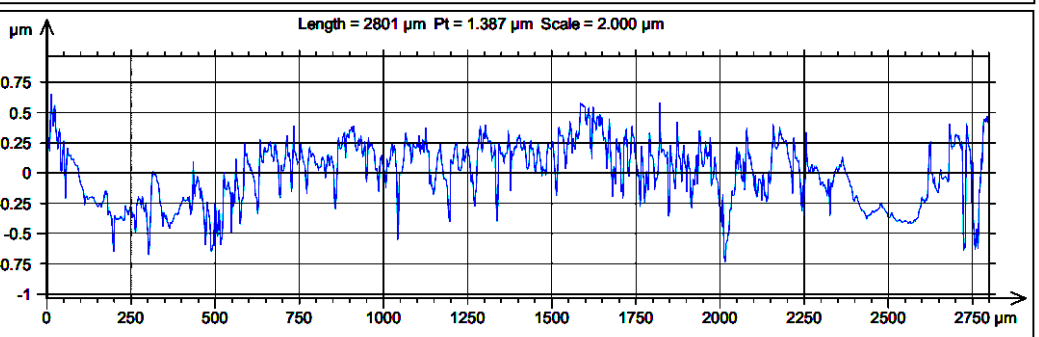

Figura 69 - Perfil de profundidades de desgaste lubrificado no FBM obtidos no perfilômetro óptico (no sentido do movimento). As escalas empregadas são diferentes. 

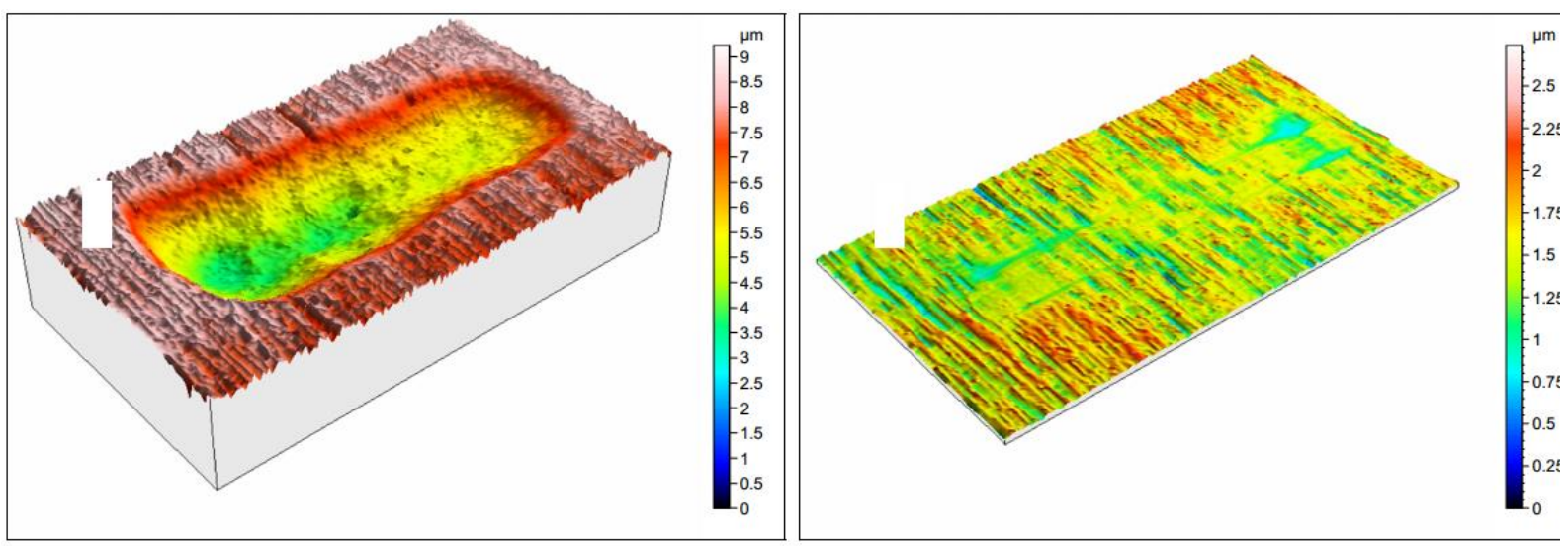

Figura 70 - Marca de desgaste em 3D (lubrificado). (a) FC; (b) FB.

5.3.3.2 Caracterização por MEV das superfícies de desgaste após o ensaio

A Figura 71 apresenta as marcas originadas durante o ensaio de desgaste por deslizamento nas amostras de FC. Analisando as superfícies, percebe-se que as marcas (riscos na vertical) originadas na etapa de usinagem foram removidas na região ensaiada. A região central (Figura $71 \mathrm{~b}$ e c), a superfície não é uniformemente lisa, buracos foram encontrados e estes podem estar associados a grafitas na superfície que se desprenderam (setas pretas). Nas regiões próximas aos pontos mortos (extremidades do curso do movimento), Figura 71f, há evidência de deformação plástica. Ou seja, ocorre o desprendimento parcial de grafita e, em alguns casos ocorre o encobrimento delas.

As evidências apresentadas na Figura 72, amostra de FBM, percebe-se riscos de usinagem na região ensaiada, e a grafita é exposta, mas não foi arrancada. 
(a)

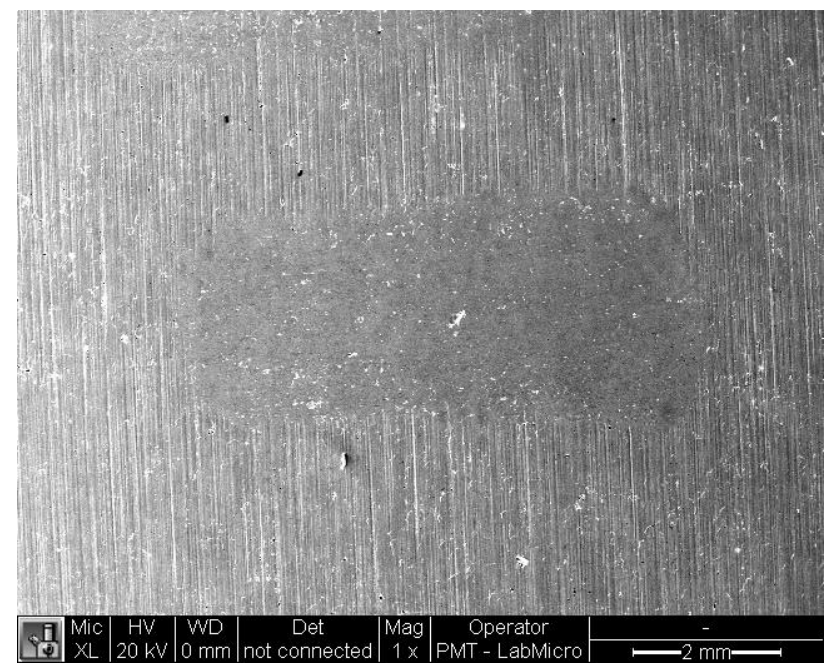

(b)

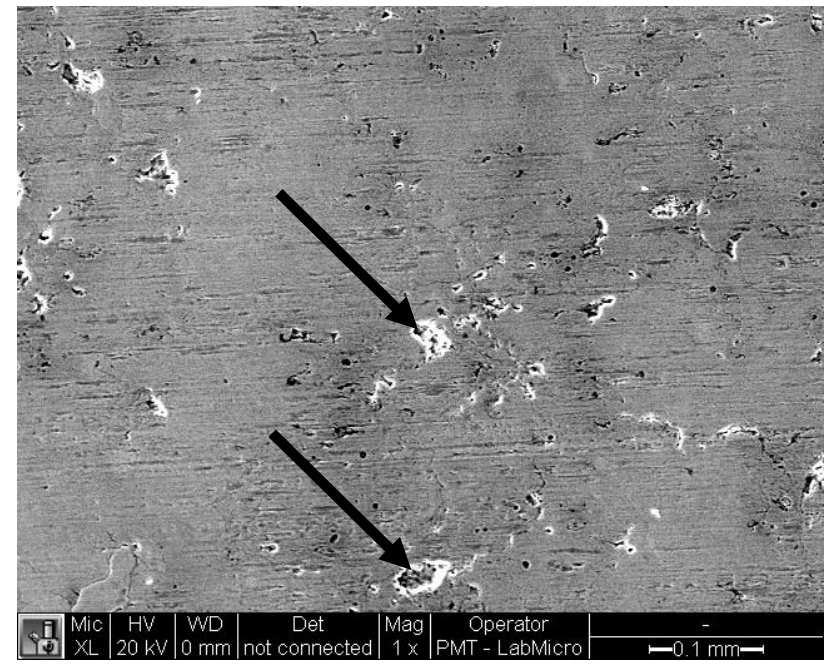

(c)

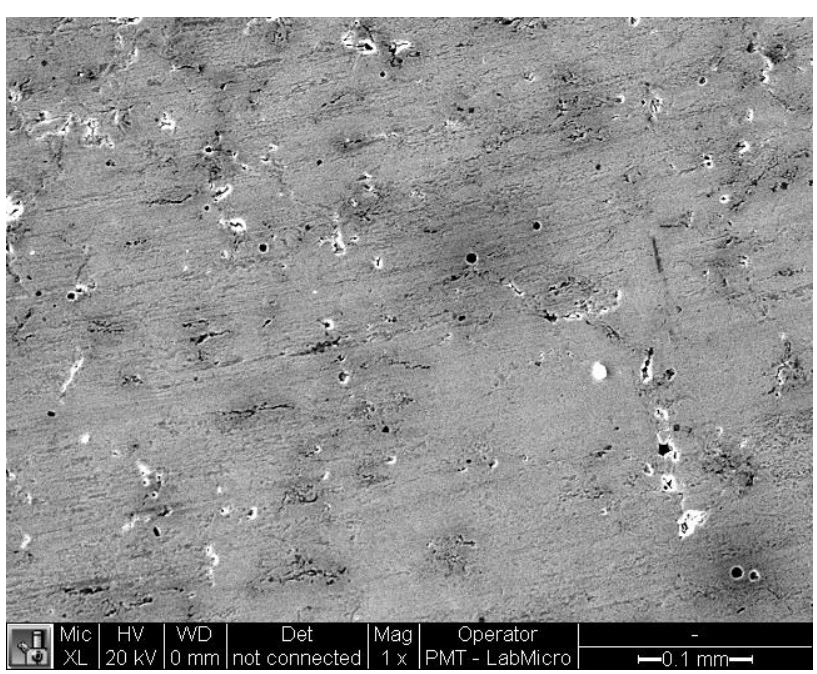

(d)

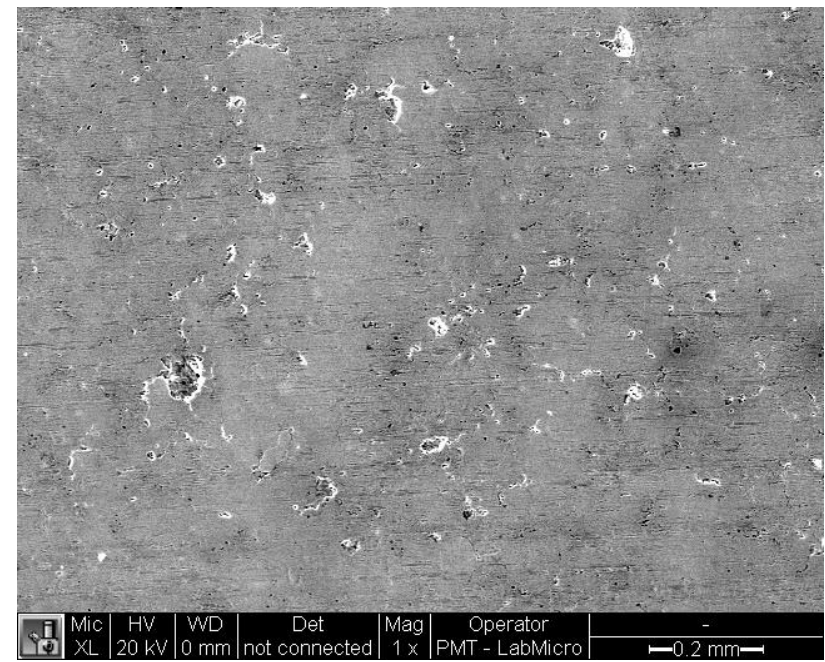

(e)

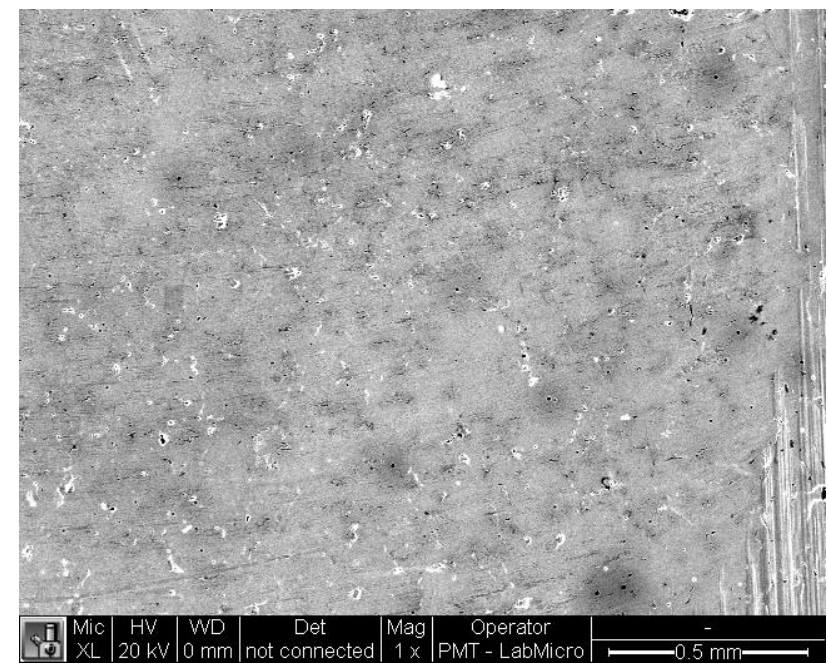

(f)

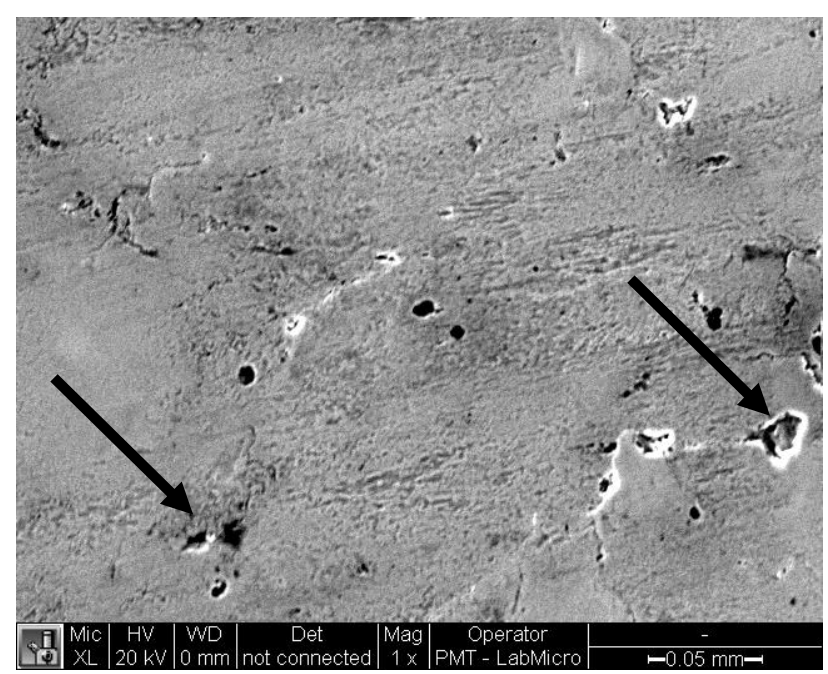

Figura 71 - MEV da amostra FC. (a) região ensaiada; (b), (c) região central; (d), (e), (f) região ponto morto. 
(a)

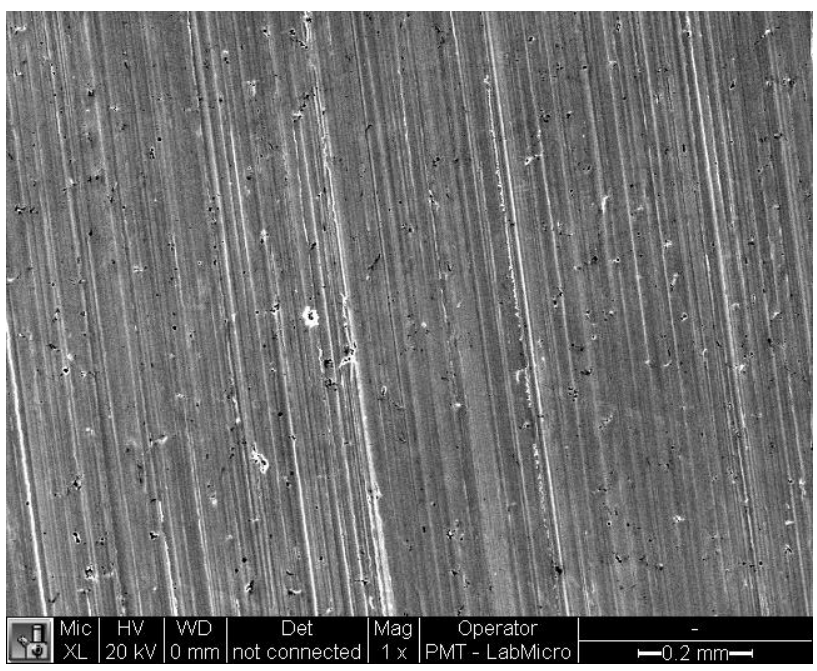

(c)

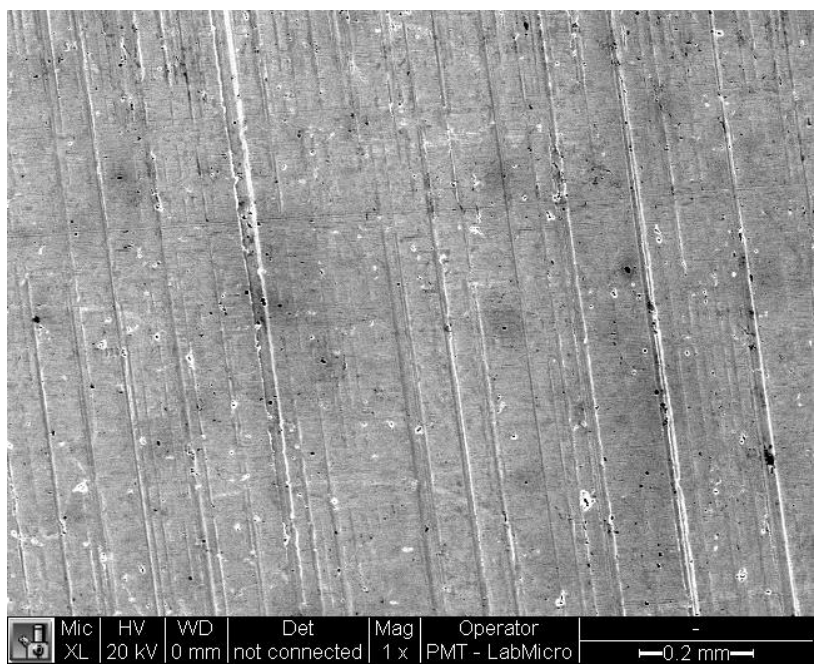

(b)

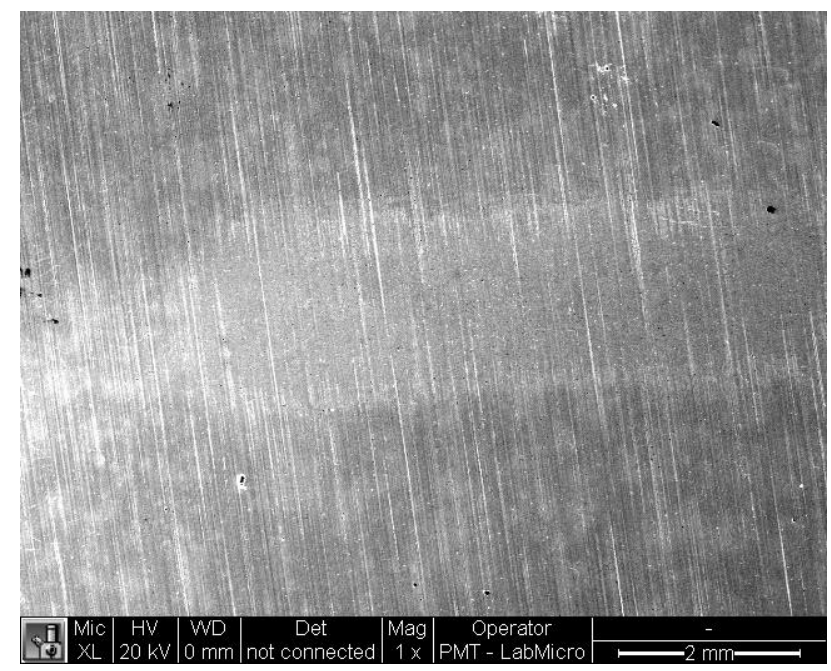

(d)

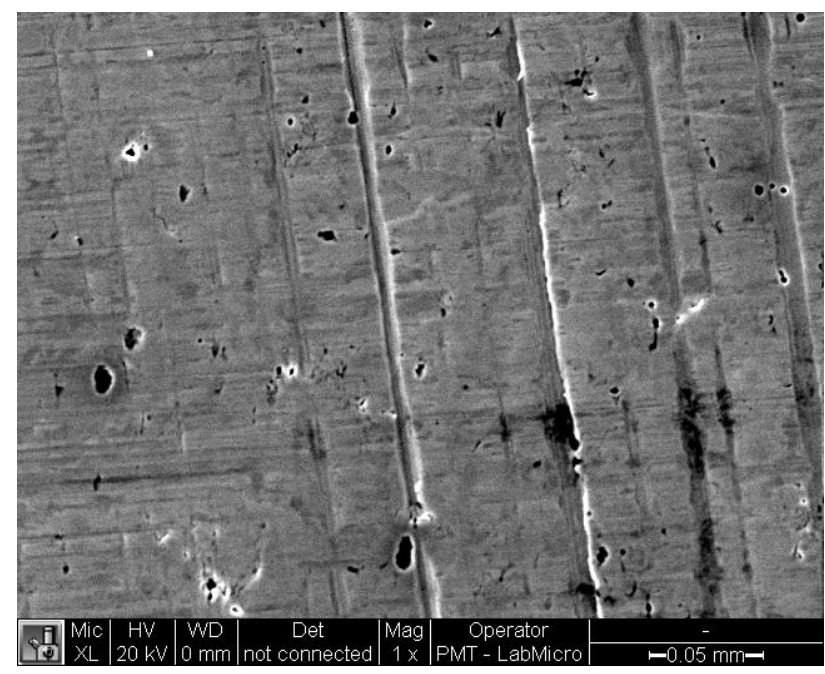

Figura 72 - MEV da amostra FBM. (a) região não ensaiada; (b) região ensaiada; (c) região central; (d) região ponto morto.

\subsubsection{Ensaio de desgaste: regime seco}

A Figura 73 e Figura 74 representa a curva de desgaste por deslizamento a seco representativos de 3 testes realizados em uma mesma amostra de FC e FBM. As três medições do FC no gráfico apresentado na Figura 73 são identificados por FC1, FC2, e FC3, o mesmo procedimento foi feito para identificar as cinco medições realizadas no FBM (Figura 74). O gráfico apresentado na Figura 75 corresponde à média de três amostras de FC e de FBM obtidos nos testes de desgaste por deslizamento realizados no OPTIMOL a seco. Analisando as duas curvas percebe-se que a amostra de FC apresenta coeficiente de atrito menor em relação a mostra FBM. 


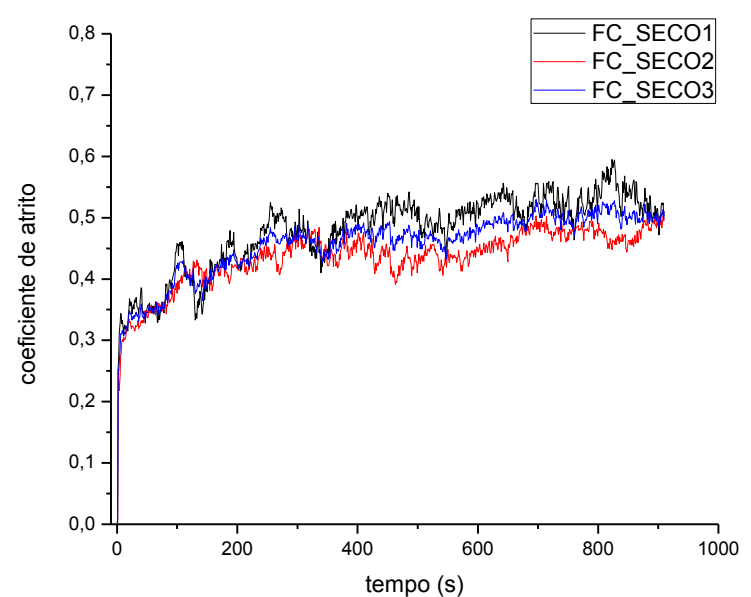

\section{Parâmetros usados no ensaio}

Pré-carga: $50 \mathrm{~N}$; carga utilizada: $50 \mathrm{~N}$;

frequência: $20 \mathrm{~Hz}$; Amplitude: $2 \mathrm{~mm}$,

tempo: $15 \mathrm{~min}$; Temperatura: $25^{\circ} \mathrm{C}$;

Tribossistema: anel e camisa (FC).

Figura 73 - Curva de atrito por deslizamento de três testes realizados FC a seco.

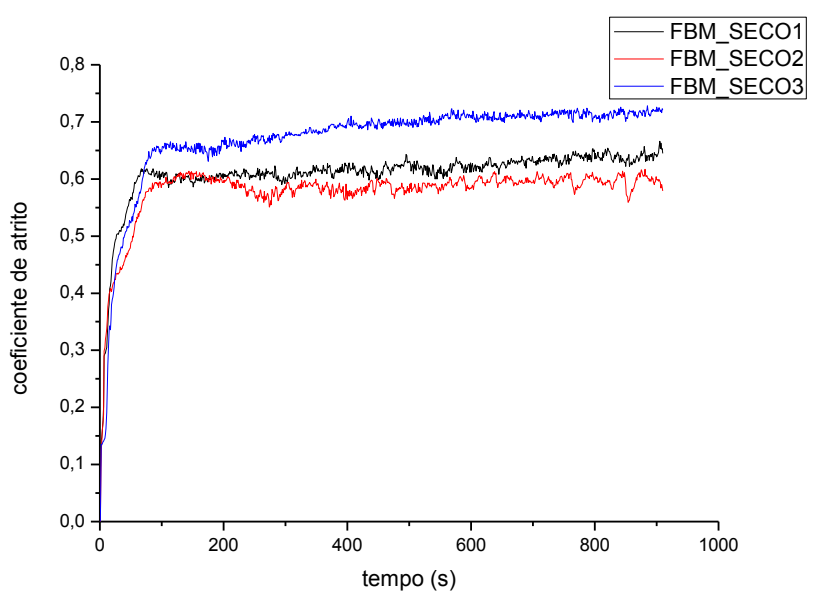

Parâmetros usados no ensaio

Pré-carga: $50 \mathrm{~N}$; carga utilizada: $50 \mathrm{~N}$;

frequência: $20 \mathrm{~Hz}$; Amplitude: $2 \mathrm{~mm}$, tempo: $15 \mathrm{~min}$; Temperatura: $25^{\circ} \mathrm{C}$;

Tribossistema: anel e camisa (FBM).

Figura 74 - Curva de atrito por deslizamento de três testes realizados no FBM a seco.

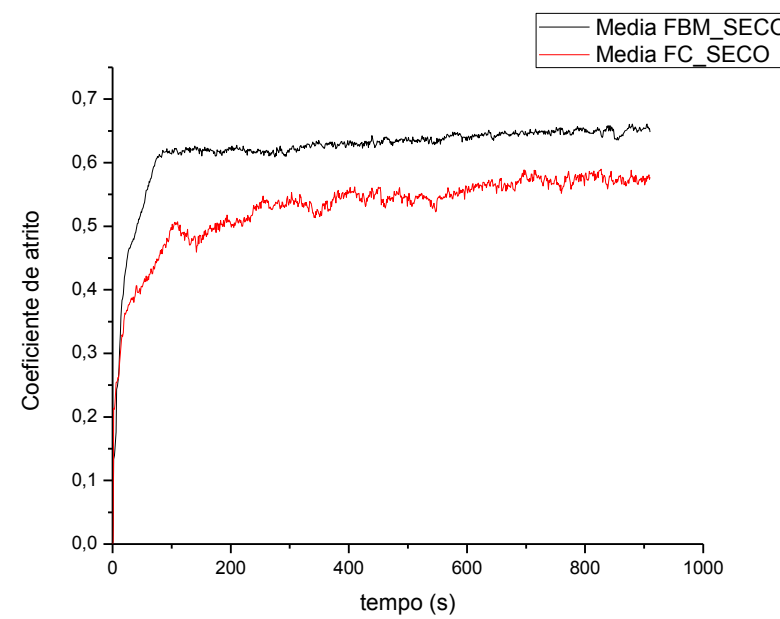

Parâmetros usados no ensaio

Pré-carga: $50 \mathrm{~N}$; carga utilizada: $50 \mathrm{~N}$; frequência: $20 \mathrm{~Hz}$; Amplitude: $2 \mathrm{~mm}$, tempo: 15 min; Temperatura: $25^{\circ} \mathrm{C}$;

Tribossistema: anel, e camisa (FC e FBM).

Figura 75 - Curva de atrito por deslizamento das amostras de FC e FBM a seco. 
O efeito do endurecimento da matriz em ferros fundidos nodulares também foi estudado por SUGISHITA e FUJIYOSHI [57-59]. Eles verificaram que o endurecimento da matriz promove menor deformação plástica em regiões adjacentes aos nódulos de grafita em condições de desgaste por deslizamento em regime reciprocante sem lubrificação. Os autores reportaram que em ferros fundidos de matriz ferrítica o coeficiente de atrito foi menor do que em matriz temperada e revenida. e justificaram que o desprendimento de grafita em amostras de matriz ferrítica proporcionou a formação de um filme de grafita em entre os corpos em contato, resultando em menores coeficiente de atrito e taxa de desgaste.

5.3.4.1 Caracterização das superfícies de desgaste após o ensaio a seco por MO e perfilometria óptica

As macrografias feitas na lupa estereoscópica podem ser acompanhadas na Figura 76 e Figura 77; a Figura 76a ilustra o anel que foi usado em conjunto com o contra-corpo de FC (Figura 76b), a mesma organização foi feita na Figura 77, anel (Figura 77a) e o contra-corpo de FBM (Figura 77b).

As marcas de desgaste nos dois anéis (Figura 76a e Figura 77a), sendo um deles colocado em contato a seco com o FC e o outro em contato com o FBM possuem aproximadamente o mesmo tamanho. Esta mesma análise foi feita nas marcas de desgaste no FC e FBM. A marca de desgaste na superfície do FBM foi ligeiramente inferior em relação ao FC (Figura 76b e Figura 77b).

A profundidade das marcas de desgaste foi analisada no perfilômetro óptico (Figura 78 e Figura 79); comparando o mapeamento de profundidades nos dois materiais o desgaste no FBM é mais homogêneo.

O perfil de desgaste do FC (Figura 80) e do FBM (Figura 81) dos dois materiais apresentam-se iguais, assim como, os volumes aparentes (Figura 82). O volume aparente do FC ficou na faixa de 26767-46907 $\mu^{3}$, o FB 26580-56033 $\mu \mathrm{m}^{3}$. 


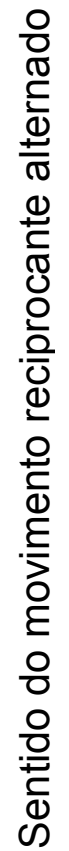

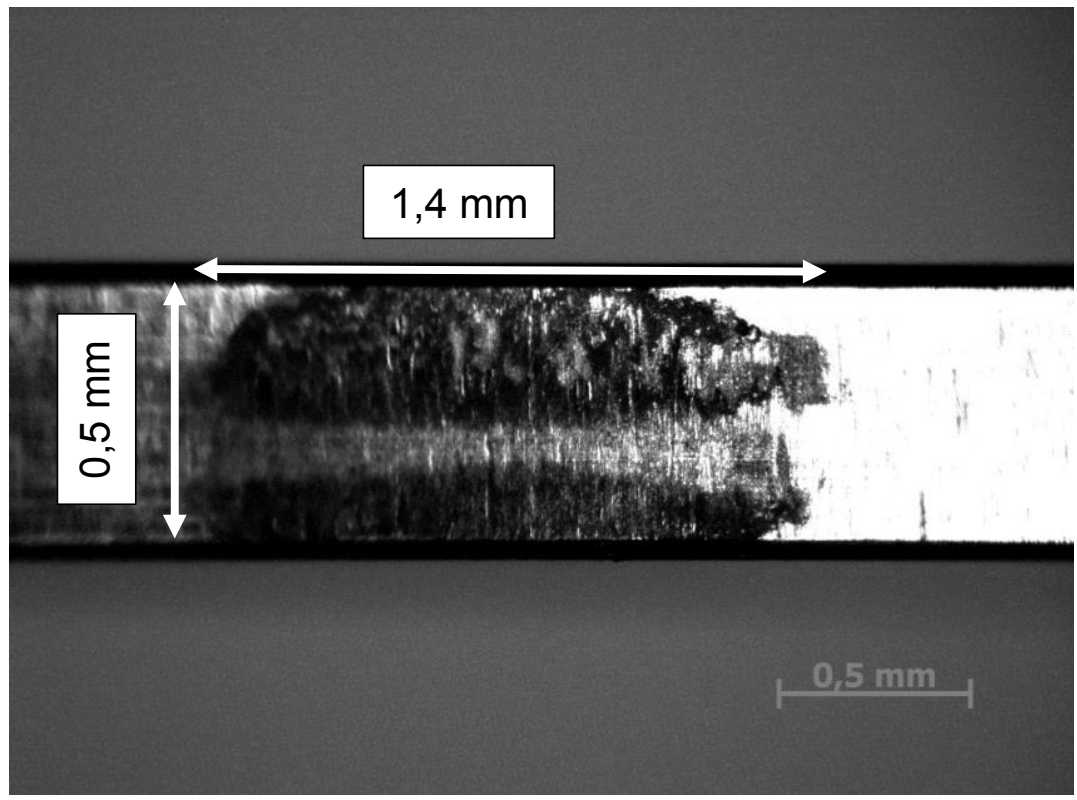

(a)

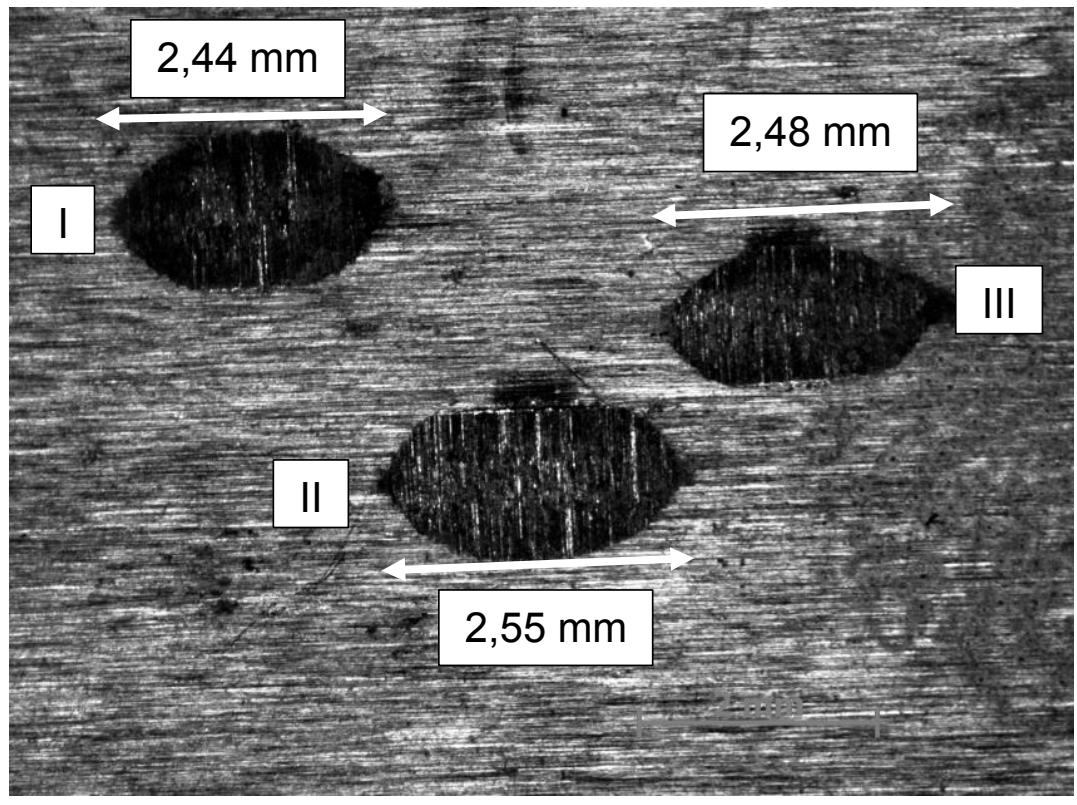

Figura 76 - marcas de desgate a seco (a) contra-corpo (anel); (b) corpo de FC. 


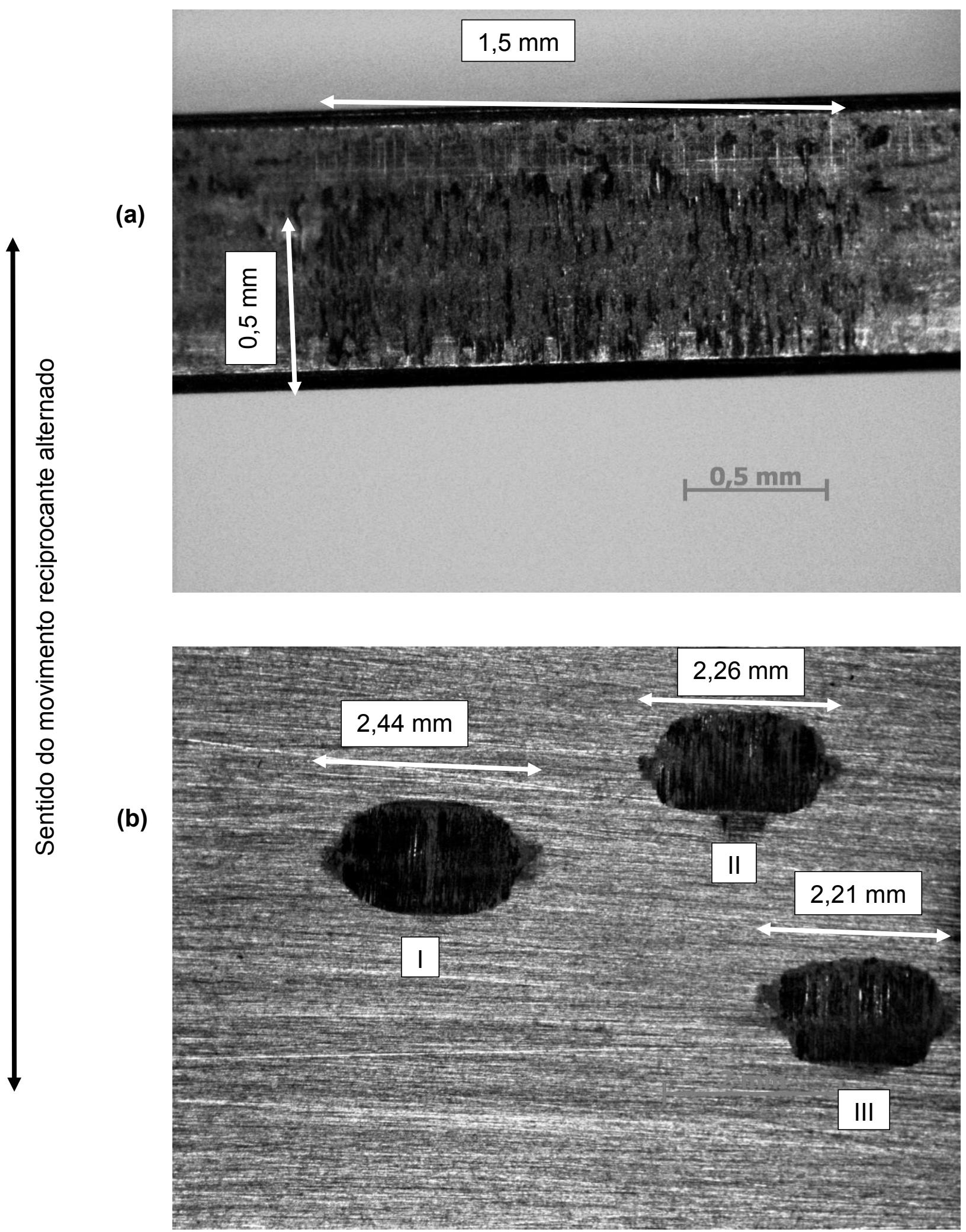

Figura 77 - marcas de desgate a seco (a) contra-corpo (anel); (b) corpo de FBM. 


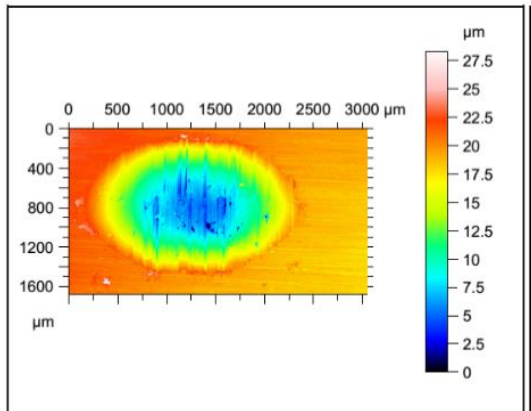

I

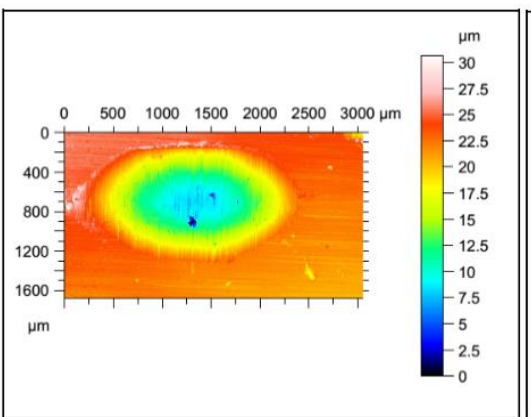

II

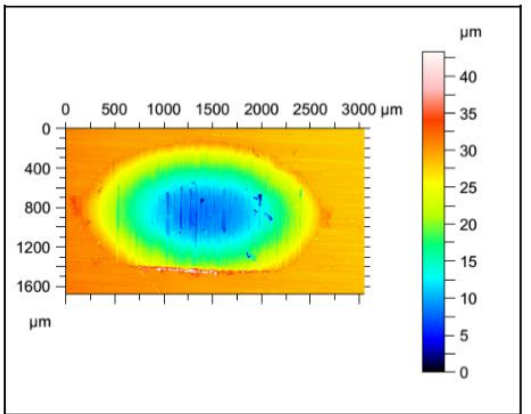

III

Figura 78 - Profundidades de desgaste a seco no FC obtidos no perfilômetro óptico

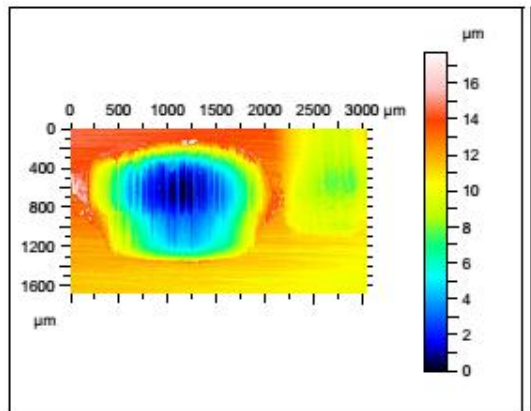

I

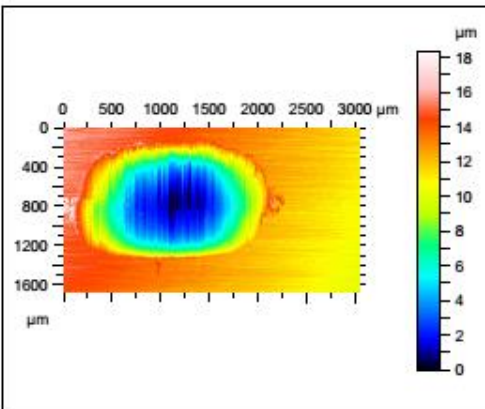

II

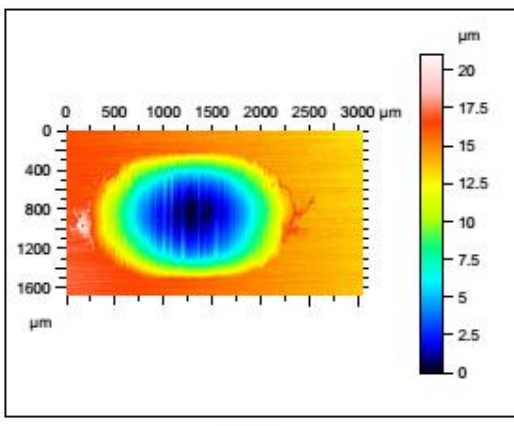

III

Figura 79 - Profundidades de desgaste no a seco FB obtidos no perfilômetro óptico

(I)

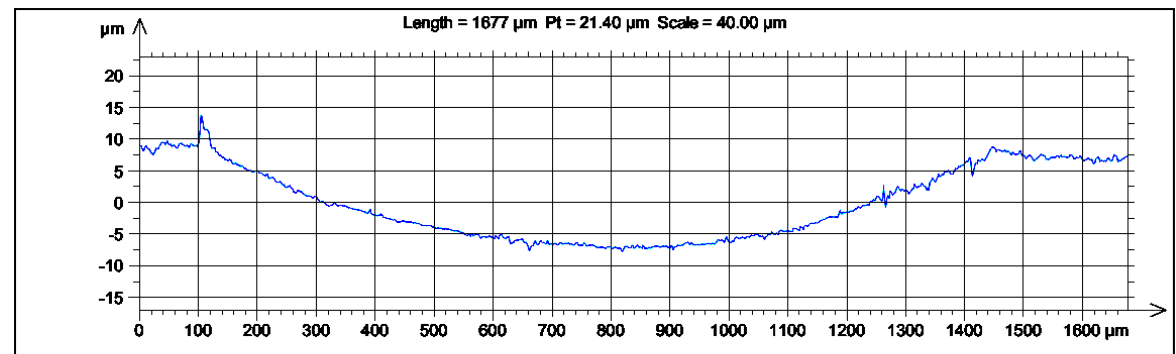

(II)
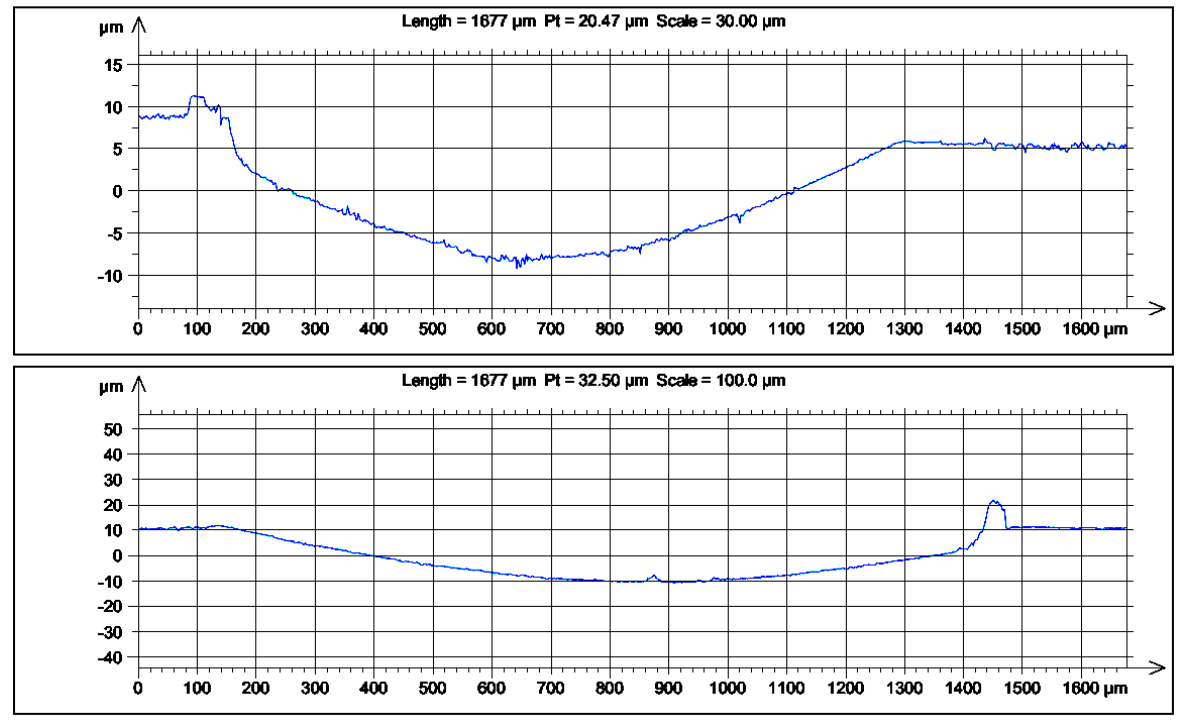

Figura 80 - Perfil de profundidades de desgaste a seco do FC obtidos no perfilômetro óptico (no sentido do movimento). 
(I)

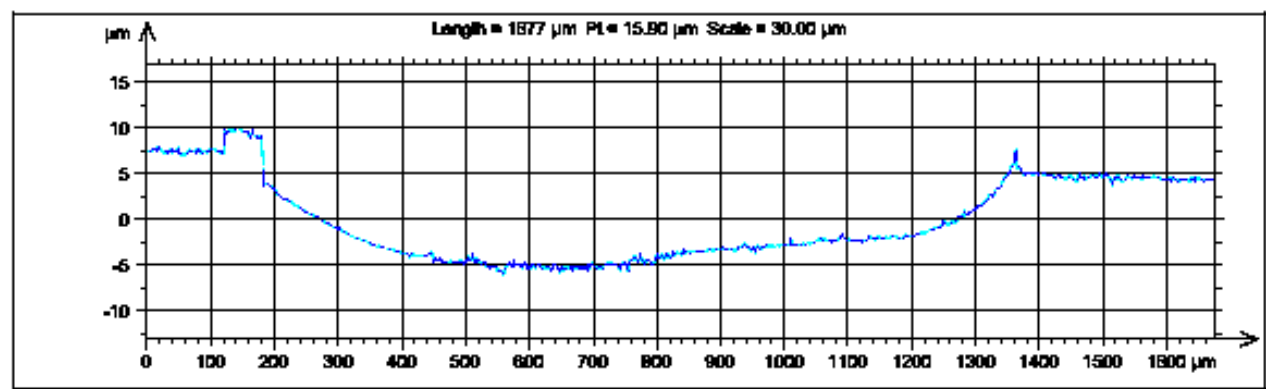

(II)

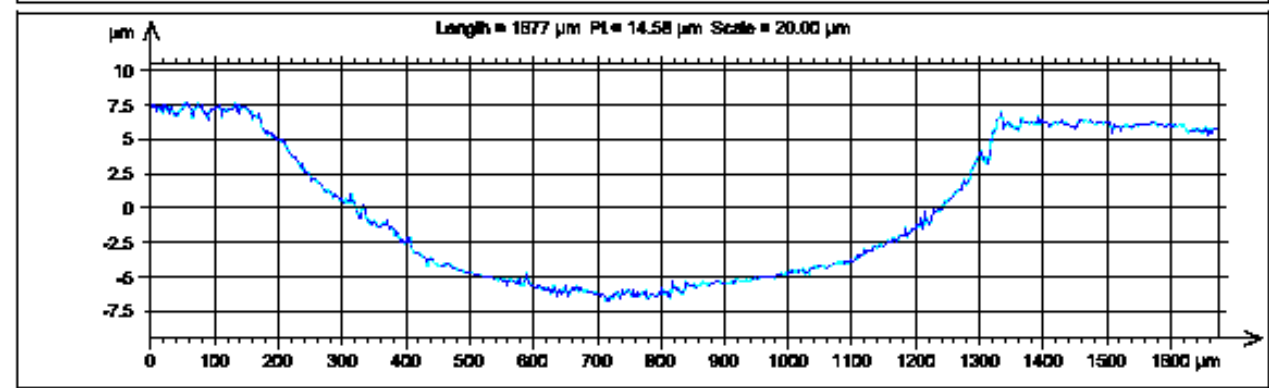

(III)

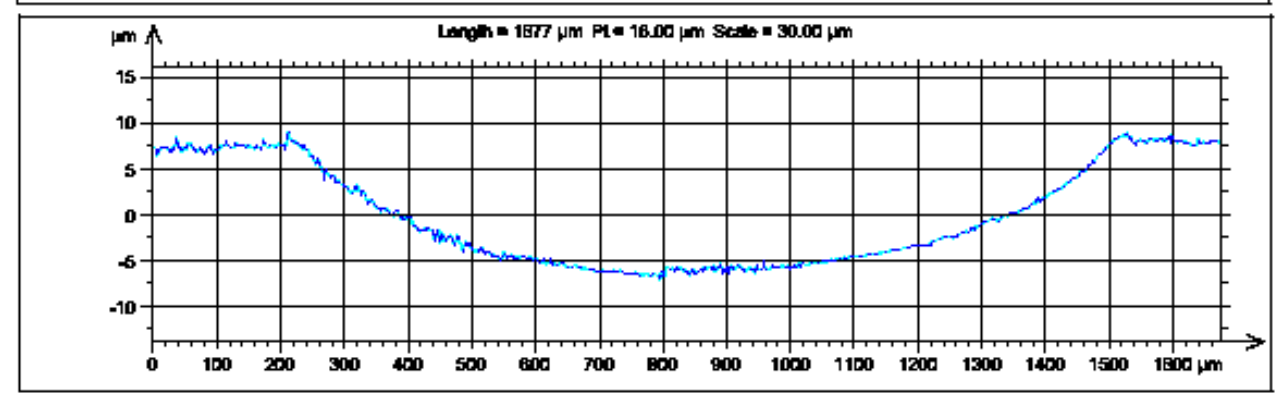

Figura 81 - Perfil de profundidades de desgaste a seco do FBM obtidos no perfilômetro óptico (no sentido do movimento.
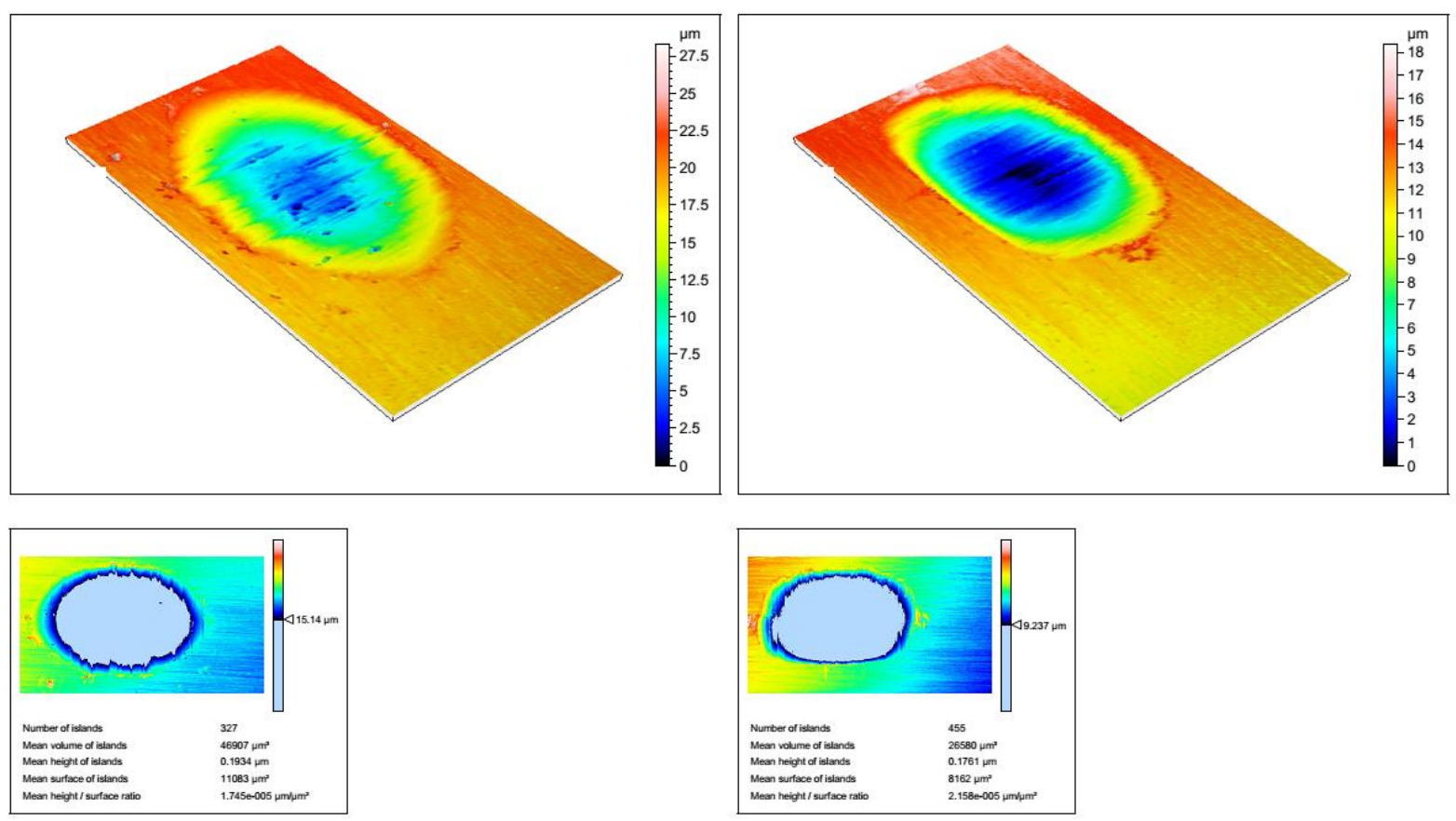

Figura 82 - Volume aparente de desgaste (seco). (a) FC; (b) FB. 
5.3.4.2 Caracterização por MEV das superfícies de desgaste após o ensaio

A Figura 83 mostra a superfície do FC após os testes de desgaste por deslizamento a seco. A Figura 83a mostra a região do ponto morto e a Figura 83b mostra a região central. Nota-se que a superfície foi deformada plasticamente e em alguns pontos houve encobrimento dos veios de grafita. A microestrutura após o teste corrobora os resultados de coeficiente de atrito apresentados no item 5.3.4. A Figura $83 \mathrm{c}$ ilustra a exposição de grafita na superfície; a Figura $83 \mathrm{~d}$ mostra vazios originados possivelmente pelo desprendimento de grafita que dá origem à formação do filme grafita no meio interfacial. Percebe-se ainda desgaste abrasivo originados no contato entre $\mathrm{o}$ anel e $\mathrm{o}$ ferro fundido cinzento. Superfície de desgaste semelhante foi identificada por SANTOS FILHO [55] no fim de curso de um cilindro de ferro fundido cinzento (Figura 84)

$\mathrm{Na}$ Figura 85 são mostradas as marcas de desgaste produzidas na superfície do FBM. A Figura 85a corresponde à região de ponto morto e a Figura 85b é correspondente à região central. É possível identificar as marcas horizontais originadas pelo movimento reciprocante alternado do anel em relação à amostra. Após os 15 minutos de teste a grafita permanece na superfície, ou seja, o coeficiente de atrito apresentado na Figura 75 é resultado do contato entre a superfície de FBM (matriz de martensita revenida) e o anel de aço com superfície nitretada. A matriz dura de martensita revenida possivelmente minimizou a deformação plástica de regiões adjacentes aos nódulos de grafita, evitando o desprendimento da grafita no tribossistema. 
(a)

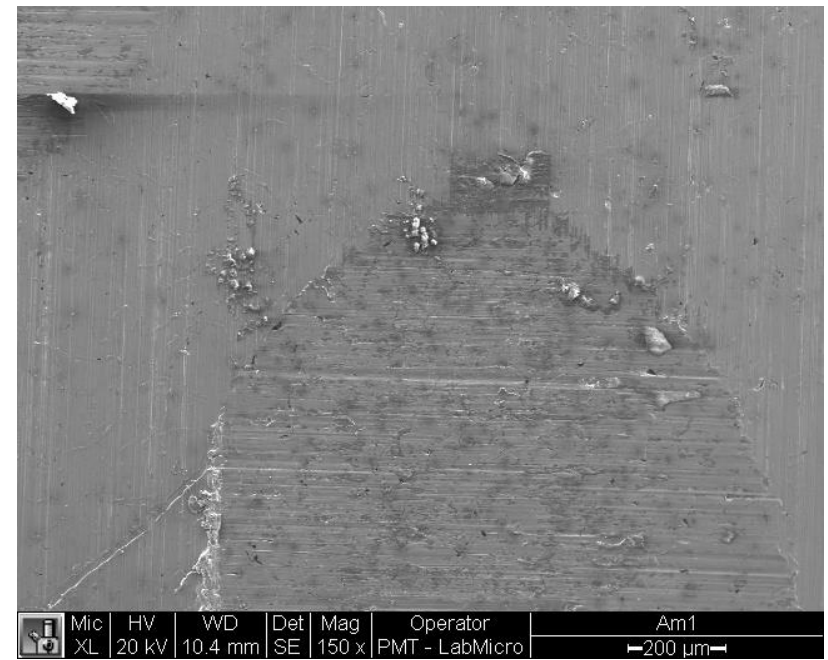

(c)

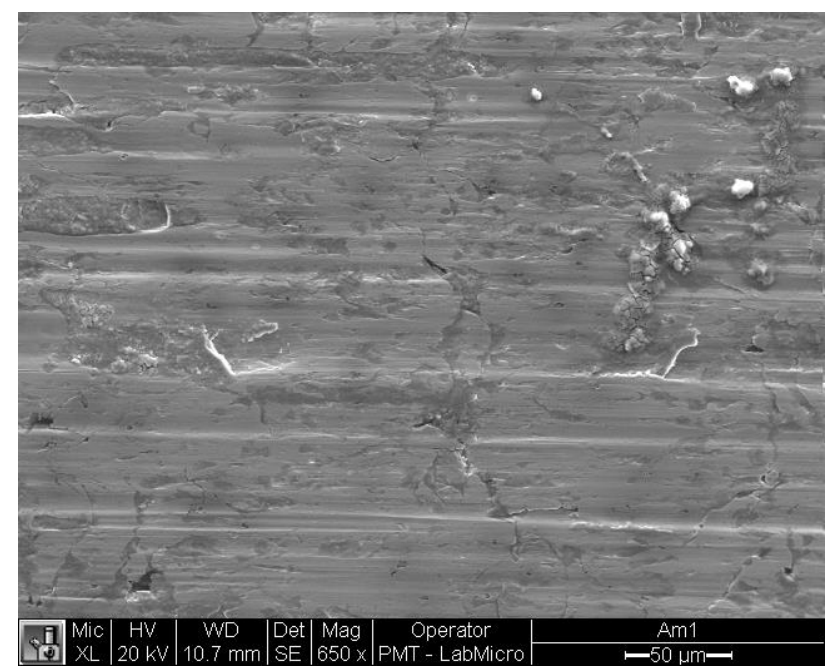

Figura 83 - MEV da amostra FC a seco. (a) ponto morto; (b), (c), (d) região central. (b)

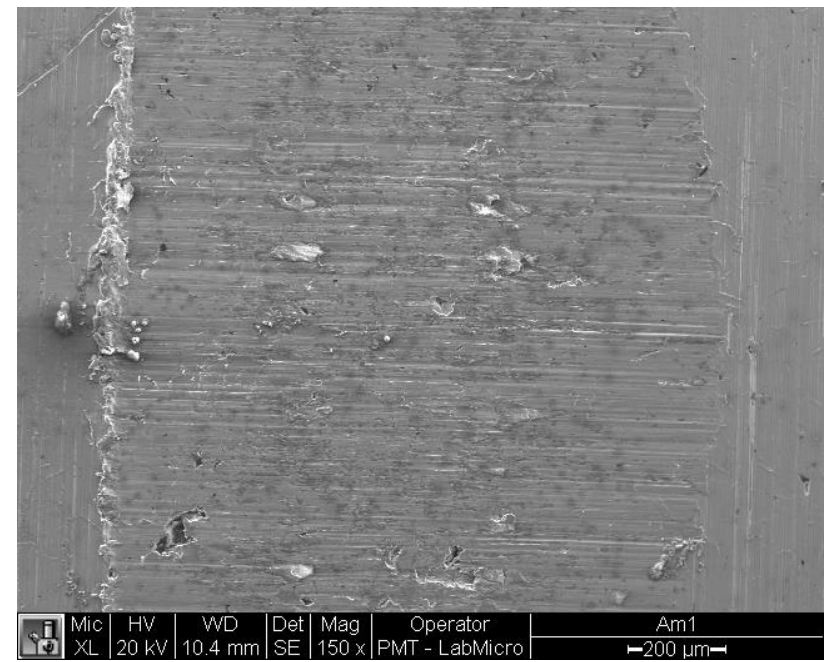

(d)

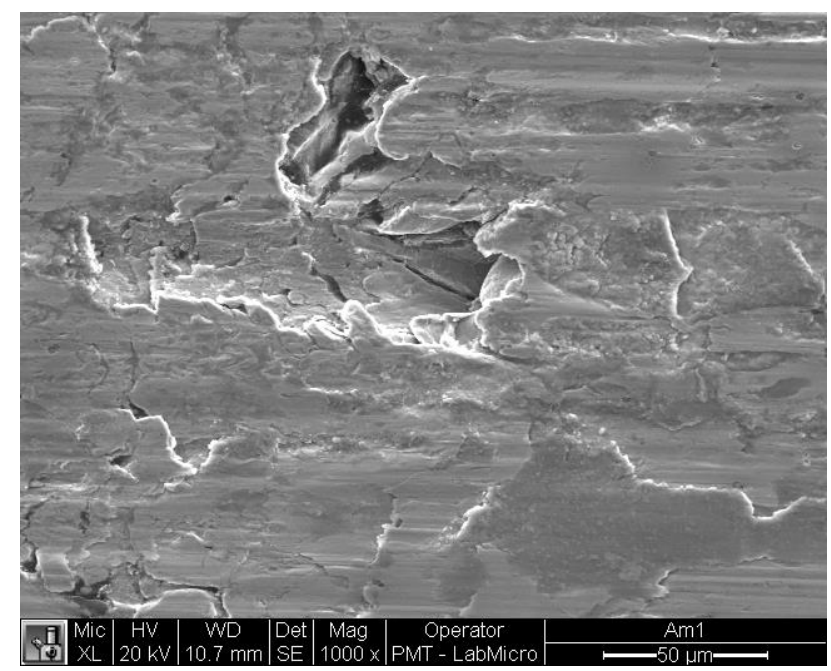

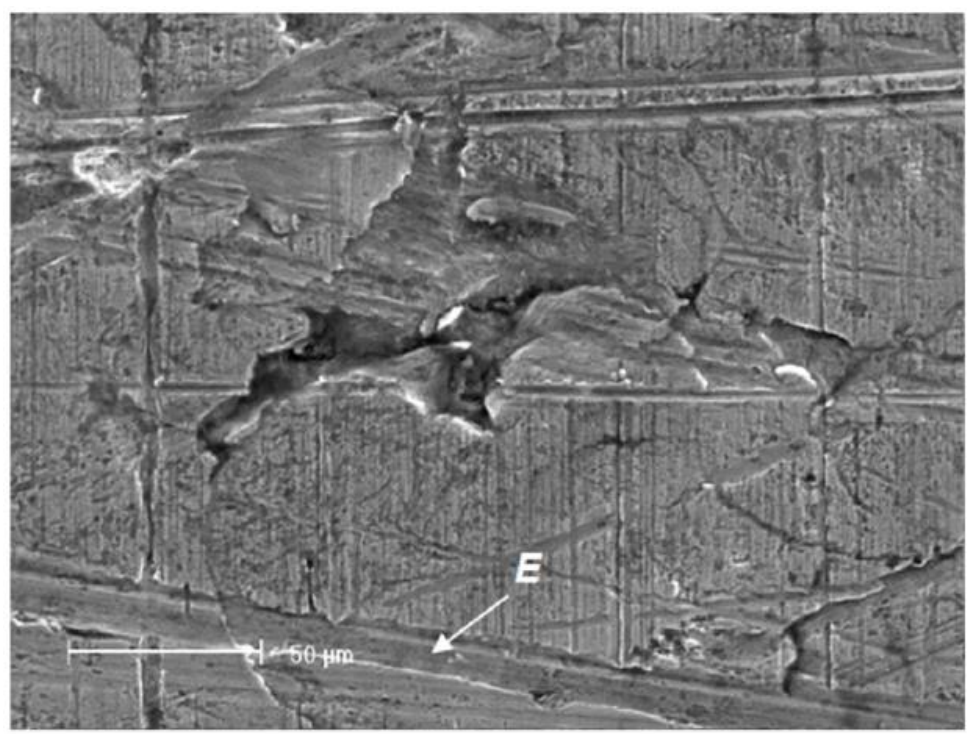

Figura 84 - Região de fim de curso submetido a ensaio de durabilidade usando dinamômetro [55]. 
(a)

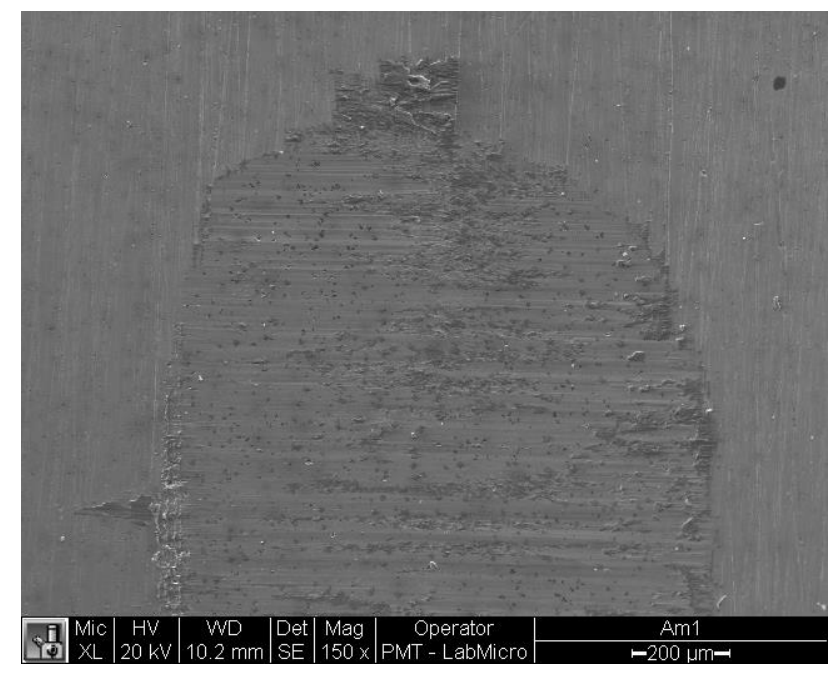

(c)

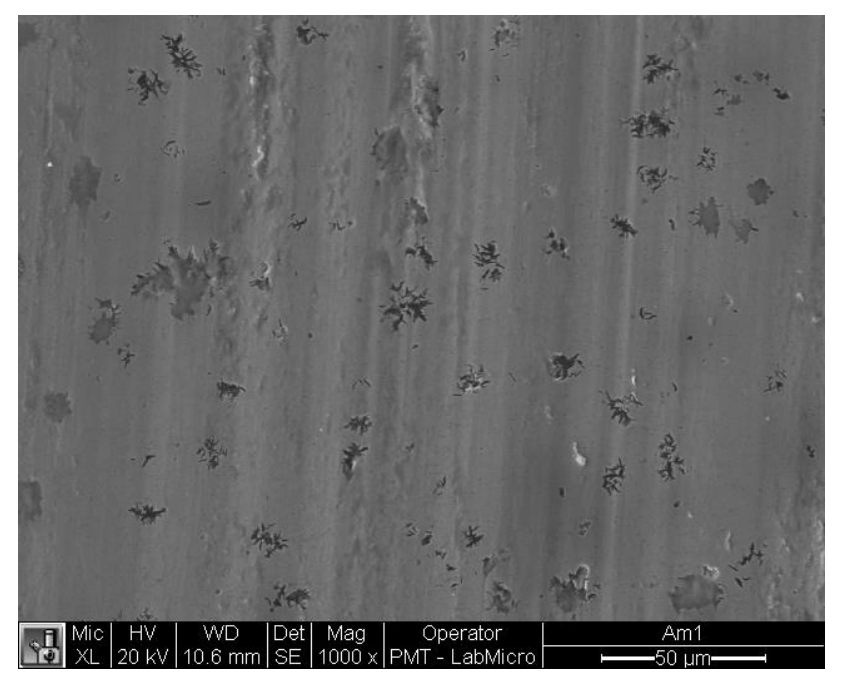

(b)

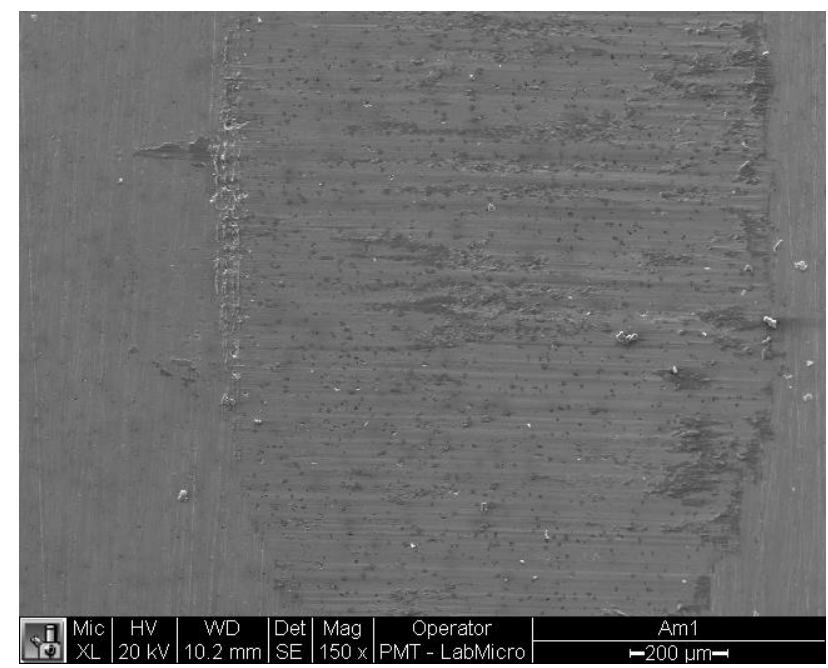

(d)

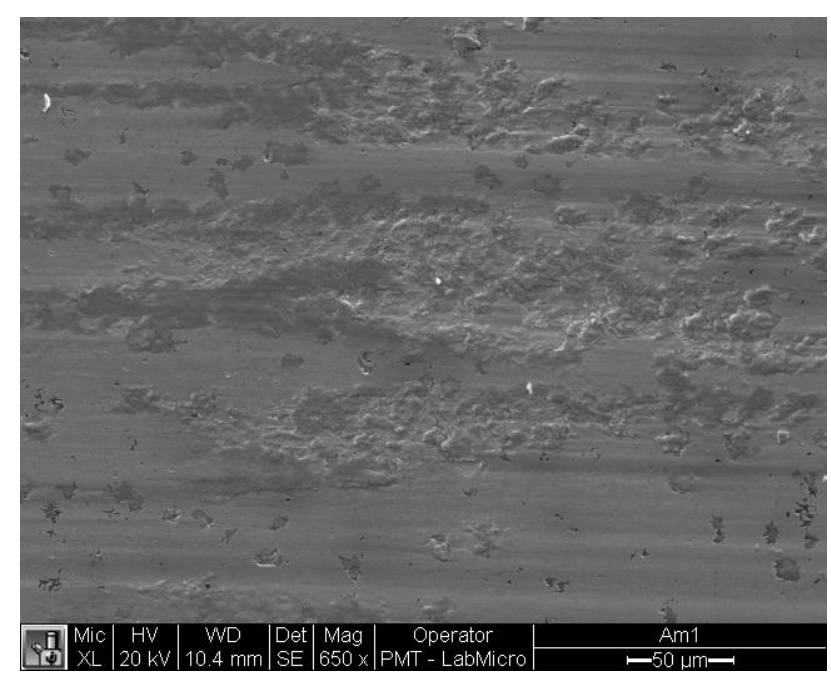

Figura 85 - MEV da amostra FBM. (a) ponto morto; (b), (c), (d) região central.

\subsubsection{Discussão dos resultados apresentados}

A rugosidade da superfície é um parâmetro muito importante a ser controlado, diferenças de rugosidade podem introduzir variações muito grandes entre as medidas quando se trata de ensaios tribológicos. A superfície de ensaio dos dois materiais apresentou spk médio de 0,24 e 0,26, ou seja, não existe diferença estatística entre as superfícies ensaiadas.

O FBM em regime lubrificado tem melhor resistência ao desgaste em relação ao FC. Durante o running-in o FB também apresenta melhores resultados comparados com o FC. O coeficiente de atrito e o tempo de running-in FBM durante esta etapa é 
menor se comparado com o FC.

As marcas de desgaste no corpo analisadas na lupa estereoscópica e perfilômetro óptico indicaram uma maior remoção de material no FC, os parâmetros rugosidade da superfície, temperatura, força normal, amplitude, tempo de ensaio lubrificante, contracorpo (anel) e deslocamento são fixos. O único parâmetro variante é a dureza da superfície. As marcas de desgaste originadas no anel usados em conjunto com o FC são maiores em relação ao FBM, ou seja, como a área de contato do FC é maior, a pressão exercida na superfície com o passar do tempo é menor do que no FBM. Uma possível explicação para esta disparidade de comportamento decorre da tensão máxima e da tensão média decorrentes da aplicação da carga de $50 \mathrm{~N}$ no ensaio: calculando as tensões máxima e média (equações 35-39) utilizando a área de 2,9.10-7 $\mathrm{m}^{2}$ de contato, obtêm-se $250 \mathrm{MPa}$ e 169MPa respectivamente. Estas tensões, tanto a máxima como a média, são maiores do que o limite de escoamento do FC, que pode ser estimado a partir da dureza (1/3 do valor da pressão de endentação) como sendo aproximadamente $378 \mathrm{MPa}$. Por outro lado, estes valores são menores do que o limite de escoamento do FBM, estimado em 1116MPa.

O tempo aproximado para que o FC passe do regime transitório para a condição permanente foi 15 minutos, por este motivo os testes a seco foram feitos neste período de tempo com a finalidade de testar o FBM em condições de severas de desgaste.

Os resultados de desgaste a seco, mostraram que as duas amostras ensaiadas apresentaram resultados parecidos. A análise das marcas de desgaste dos anéis apresentou aproximadamente o mesmo tamanho; o mesmo aconteceu nos corpos (FC e FBM). A profundidade de desgaste nos dois corpos também apresentou medidas parecidas, ou seja, a pressão de contato do FC e FBM são aproximadamente iguais. As micrografias feitas no MEV na superfície de desgaste do FC mostraram que a grafita lamelar do FC ficaram encobertas e revelaram buracos na superfície, originados possivelmente pelo desprendimento de grafita da superfície do FC. A grafita do FB permanece exposta na superfície. No entanto, como a martensita revenida presente na superfície minimiza a deformação plástica ao redor dos nódulos de grafita dificultando o encobrimento da superfície sobre a grafita presente na superfície.

A morfologia da grafita também tem um papel importante no coeficiente de atrito em regime lubrificado em ensaios pino/disco. Prasad [60] estudou a morfologia da grafita lamelar e nodular em matriz de ferrita e perlita e concluiu que a grafita lamelar do FC retarda a mudança de mecanismo de desgaste a medida que se aumenta a 
força normal.

Os resultados deste trabalho mostraram que modificações microestruturais na superfície de desgaste por deslizamento a seco influenciam muito pouco nos estágios iniciais do teste para estes dois materiais. Possivelmente debris duros que se desprenderam da superfície do FBM durante o movimento reciprocante alternado a seco poderiam estar sendo inseridos no meio interfacial entre o anel e o FBM, acarretando no aumento do coeficiente de atrito do FBM. 


\subsection{CONCLUSÕES}

- Modificações de microestrutura objetivando o endurecimento na superfície reduzem o desgaste por deslizamento em condições de lubrificação;

- O coeficiente de atrito do ferro branco modificado nos testes de desgaste por deslizamento em regime lubrificado durante o running-in é menor do que o do ferro fundido cinzento;

- O tempo de running-in do ferro branco modificado nos testes de desgaste por deslizamento em regime lubrificado foi menor do que o ferro fundido cinzento;

- O endurecimento da matriz dificulta o desprendimento de grafita;

- Em condições de desgaste a seco durante os instantes iniciais de teste (15 min), modificações na matriz tem pouca influência no desgaste de material. 


\section{CONCLUSÃO GERAL}

- A grafitização secundária no ferro fundido cinzento submetido a têmpera e revenimento ocorre após $5 \mathrm{~h}$;

- A contração durante o reaquecimento apresentou uma redução da austenita retida 12 para $8 \%$, ocorrendo partição de carbono na austenita de 0,3\%;

- A cinética de grafitização do ferro fundido cinzento;

- A grafitização secundária no ferro branco maleabilizado ocorre em tempos relativamente curtos;

- A dureza do ferro branco maleabilizado é relativamente constante até 15 minutos a $900{ }^{\circ} \mathrm{C}$, sendo esta dureza compatível com materiais usados em componentes usados em rolamentos;

- A energia de ativação obtida durante a etapa de aquecimento para três diferentes temperaturas usando dilatometria é aproximadamente igual a energia de ativação da difusão do $\mathrm{Fe}$ e do Si;

- A cementita do ferro branco maleabilizado é totalmente dissolvida após $1 \mathrm{~h}$ de tratamento a $900{ }^{\circ} \mathrm{C}$ e a grafita para de crescer;

- Em regime lubrificado o running-in do ferro branco modificado apresentou coeficiente de desgaste e desgaste menor do que o ferro fundido cinzento;

- O tempo de running-in do ferro branco modificado também é menor do que o ferro fundido cinzento;

- Durante o regime estacionário o coeficiente é igual para os dois materiais;

- O coeficiente de atrito nos desgastes por deslizamento a seco do ferro fundido cinzento apresentou-se menor do que o ferro branco modificado. 


\section{SUGESTÕES PARA TRABALHOS FUTUROS}

- Testar o desgaste por deslizamento do Ferro Branco Maleabilizado previamente atacadas, deixando a grafita em alto relevo;

- Simulação do Ferro Branco Maleabilizado com os parâmetros reais de funcionamento do motor;

- Testar amostras de Ferro Branco Maleabilizado com dissolução completa da cementita em testes de desgaste por deslizamento;

- Adicionar porcentagens de grafita no lubrificante e analisar o comportamento tribológico do Ferro fundido Cinzento e Ferro Branco Maleabilizado;

- Caracterização da estrutura da grafita por espectroscopia Raman no ferro fundido cinzento e no ferro fundido branco modificado (sob diferentes tempos de tratamento térmico). 


\section{REFERÊNCIAS}

[1] HOLMBERG, K.; ANDERSSON, P. e ERDEMIR, A. Global energy consumption due to friction in passenger cars. Tribology International, v. 47, p. 221-234, 2012.

[2] GUESSER, W. L. e KUHL, R. Ferros Fundidos Maleáveis. $1^{\text {a }}$ edição ed. Joinvile: p. $1-84,1984$.

[3] VATAVUK, J. et al. Efeito da morfologia e do número de partículas de grafita na fratura de ferros fundidos com matriz ferrítica. p. 66-70, 1990.

[4] OKAMOTO, A. Graphite formation in high-purity cold-rolled carbon steels. Metallurgical and Materials Transactions A, v. 20, n. October, p. 1989, 1989.

[5] NERI, M.; COLÁS, R. e VALTIERRA, S. Graphitization in high carbon commercial steels. Journal of Materials Engineering and Performance, v. 7, p. 467-473, 1998.

[6] BANERJEE, K. e VENUGOPALAN, T. Development of hypoeutectoid graphitic steel for wires. Materials Science and Technology, v. 24, n. 10, p. 1174-1178, 2008.

[7] ROUNAGHI, S. a; SHAYESTEH, P. e KIANI-RASHID, a R. Microstructural study in graphitised hypereutectoid cast and commercial steels. Materials Science and Technology, v. 27, n. 3, p. 631-636, 2011.

[8] EDMONDS, D. V. . e HE, K. ACCELERATION OF GRAPHITISATION IN CARBON STEELS TO IMPROVE. Super-High Strength Steels, Rome Italy, 2005.

[9] ZIMBA, J. . et al. Un-lubricated sliding wear performance of unalloyed austempered ductile iron under high contact stresses. Materials and Design, p. 431-438, 2004.

[10] DEMÉTRIO, V. B. DESENVOLVIMENTO DE AÇOS AUTOLUBRIFICANTES VIA COMPACTAÇÃO DE PÓS GRANULADOS. Dissertação (mestrado), Universidade Federal de Santa Catarina, 2012.

[11] LIMA, M. S. F. e GOLDENSTEIN, H. Structure of laser remelted surface of cast irons. Surface Engineering, v. 16, n. 2, p. 127-130, 2000.

[12] GUESSER, W. L. Propriedades mecânicas dos ferros fundidos. $1^{\text {a }}$ edição ed. Edgard Blucher, p. 336, São Paulo, 2009.

[13] SOUZA, A. e BRANCO, C. C. Metalurgia dos ferros fundidos cinzentos e nodulares. São Paulo: IPT, p. 205, 1977.

[14] GRABON, W. et al. Improving tribological behaviour of piston ring-cylinder liner frictional pair by liner surface texturing. Tribology International, v. 61, p. 102-108, 2013. 
[15] ETSION, I. e SHER, E. Improving fuel efficiency with laser surface textured piston rings. Tribology International, v. 42, n. 4, p. 542-547, 2009.

[16] TOMANIK, E. Friction and wear bench tests of different engine liner surface finishes. Tribology International, v. 41, n. 11, p. 1032-1038, 2008.

[17] YILBAS, B. S. et al. Laser treatment of carbon film coated steel surface. Surface Engineering, v. 28, n. 1, p. 57-67, 2012.

[18] BOBZIN, K. et al. Thermal spraying of cylinder bores with the Plasma Transferred Wire Arc process. Surface and Coatings Technology, v. 202, n. 18, p. 4438-4443, 2008.

[19] SUDARSHAN, T. S. e BHADURI, S. B. Wear in cylinder liners. Wear, v. 91, n. 3, p. 269-279, 1983.

[20] HUTCHINGS, I. Tribology: friction and wear of engineering materials. London: Edward Arnold, p. 273, 1992.

[21] SERBINO, E. e GOLDENSTEIN, H. Um estudo dos mecanismos de desgaste em disco de freio automotivo ventilado de ferro fundido cinzento perlítico com grafita lamelar. Chemistry \& ..., p. 123, 2005.

[22] ASTM A247 - 10 Standard Test Method for Evaluating the Microstructure of Graphite in Iron Castings.

[23] ASTM A48 / A48M - 03(2012) Standard Specification for Gray Iron Castings.

[24] OGATA, P. H.; GOLDENSTEIN, H. e GUESSER, W. L. Estudo da cinética de grafitização secundária em um ferro fundido cinzento.Congresso anual da $A B M$, São Paulo, 2011.

[25] PIMENTEL, A. S. O. Grafitização secundária em ferro fundido cinzento. Dissertação (mestrado) Universidade do Estado de Santa Catarina, 2011.

[26] ASKELAND, D. R. e FARINEZ, F. Factors Affecting the Formation of Secondary Graphite in Quenched and Tempered Ductile Iron. AFS Transactions, v. 87, p. 99106, 1979.

[27] BURKE, J. Second-stage Graphitization in a Nodular Cast Iron. Journal of Iron and Steel Institute, p. 42-45, 1960.

[28] RUNDMAN, K. B. . e ROUNS, T. N. On the Effect of Molybdenum on the Kinetics of Secondary Graphitization in Quenched and Tempered Ductile Irons. AFS Transactions, p. 487-497, 1982.

[29] KIANI-RASHID, A. R. e EDMONDS, D. V. Phase transformation study of aluminium-containing ductile cast irons by dilatometry. Materials Science and Engineering: A, v. 481-482, p. 752-756, 2008. 
[30] ANDREWS, K. Empirical formulae for the calculation of some transformation temperatures. J. Iron Steel Inst, 1965.

[31] YAKUBTSOV, I. a. e PURDY, G. R. Analyses of Transformation Kinetics of Carbide-Free Bainite Above and Below the Athermal Martensite-Start Temperature. Metallurgical and Materials Transactions A, v. 43, n. 2, p. 437-446, 2011.

[32] CULLITY, B. e STOCK, S. Elements of X-ray Diffraction. $2^{\text {nd }}$ ed, AddisonWesley Pub. CO, p. 664, 1978.

[33] TOJI, Y.; MIYAMOTO, G. e RAABE, D. Carbon partitioning during quenching and partitioning heat treatment accompanied by carbide precipitation. Acta Materialia, $\mathrm{v}$. 86, p. 137-147, 2015.

[34] CABALLERO, F. Dilatometric study of reaustenitisation of high silicon bainitic steels: Decomposition of retained austenite. Materials Transaction, v. 46, n. 3, p. 581-586, 2005.

[35] JOSÉ, A.; TOMAZ, S. e SILVA, D. A. Têmpera e partição em ferros fundidos nodulares. Dissertação (mestrado), Universidade de São Paulo, 2013.

[36] BHADESHIA, H. K. D. H. e HONEYCOMBE, R. W. K. Steels: Microstructure and Properties. 3. ed., Butterworth-Heinemann,. p. 360, 2006

[37] MARRA, K. M. e SANTOS, A. A. Método de determinação da cinética de transformação de fases a partir de curvas dilatométricas. Anais do Congresso da ABM, 2006.

[38] BURKE, J. e SWINDELLS, N. . The nucleation and growth of graphite during malleabilizing. Recent Research on cast iron. London: Gordon and Breach Science Publishers,. p. 449-474, 1968.

[39] RIOS, P. R. e PADILHA, A. F. Transformações de fase. São Paulo: Artliber,. p. 215, 2007

[40] OGATA, P. H. et al. A Study on the Camshaft Lobe Microstructure Obtained by Different Processing. $21^{\circ}$ Congresso SAE Brasil, 2012.

[41] NEEDHAM, J. Science and civilisation in China. Cambridge University Press, 1963.

[42] Materiais para máquinas-ferramenta. São Paulo: IPT, p. 95, 1974.

[43] MINKOFF, I. The physical metallurgy of cast iron. John Wiley and Soons, 1983.

[44] WIESER, C. E.;; BATES, C. E. e WALLACE, J. F. Mechanisms of Graphite Formation. Cleveland: The Ann Arbor Press, 1967.

[45] GUESSER, W. L. e PIESKE, A. Formação de grafita em ferro fundido maleável preto. Metalurgia - ABM, v. 34, n. 246, p. 319-325, 1978. 
[46] ROUNS, T. N. . e RUNDMAN, K. B. the Effect of Molybdenum on the Kinetics of Tempering Ductile Cast Irons. AFS Transactions, p. 25-36,

[47] SWINDELLS, N. e BURKE, J. THE NUCLEATION OF GRAPHITE AT AN AUSTENITE-CEMENTITE INTERFACE. p. 92-93, 1969.

[48] CLEMENS, B. M. Kinetics of Solid Phase Transformations.,. p. 209, 2003

[49] BURKE, J. The Kinetics of Phase Transformation in Metals. London: Pergamon Press Ltd,. p. 236, 1965

[50] BURKE, J. The growth of temper carbon nodules. Acta Metallurgica, p. 268-274, 1959.

[51] STACHOWIAK, G. e BATCHELOR, A. Engineering tribology. 2. ed. ButterworthHeinemann,. p. 762, 2005

[52] NEVES, J. Desenvolvimento de um equipamento para ensaio de fadiga de contato esfera sobre plano e sua aplicação na caracterização de ferros fundidos com matrizes de elevada dureza. Tese (doutorado), Universidade de São Paulo, 2006.

[53] JOHNSON, K. Contact mechanics. Cambridge University Press, p. 452, 1987.

[54] JOHNSON, K. L.; GREENWOOD, J. a. e POON, S. Y. A simple theory of asperity contact in elastohydro-dynamic lubrication. Wear, v. 19, p. 91-108, 1972.

[55] SANTOS FILHO, D. Alterações Metalúrgicas e Topográficas do Cilindro de Bloco de Motor de Combustão Interna Flex-Fuel. Dissertação (mestrado), Universidade de São Paulo, 2013.

[56] WOYDT, M. e WÄSCHE, R. The history of the Stribeck curve and ball bearing steels: The role of Adolf Martens. Wear, v. 268, n. 11-12, p. 1542-1546, 2010.

[57] BLAU, P. Running-in: Art or engineering? Journal of materials engineering, $p$. 47-53, 1991.

[58] ISMAIL, R. Running-in of Rolling-sliding Contacts. University of Twente, 2013.

[59] PRASAD, B. K. Sliding wear response of cast iron as influenced by microstructural features and test condition. Materials Science and Engineering: A, v. 456, n. 1-2, p. 373-385, 2007.

[60] TAKEUCHI, E. The mechanism of sliding wear of lubricated flake graphite cast iron. Wear, v. 15, p. 201-208, 1970.

[61] DOMMARCO, R. C.; SOUSA, M. E. e SIKORA, J. a. Abrasion resistance of high nodule count ductile iron with different matrix microstructures. Wear, v. 257, n. 11, p. 1185-1192, 2004. 
[62] DOMMARCO, R. C.; JAUREGUIBERRY, a. J. e SIKORA, J. a. Rolling contact fatigue resistance of ductile iron with different nodule counts and matrix microstructures. Wear, v. 261, n. 2, p. 172-179, 2006.

[63] BRUNETTI, C. Da preparaçao de corpos de provana vida em fadigade contato de rolamento de ferro fundido nodular austemperado. Dissertação (mestrado), Universidade Tecnológica Federal do Paraná, Curitiba, 2008.

[64] BRUNETTI, C.; LEITE, M. V. e PINTAUDE, G. Effect of specimen preparation on contact fatigue wear resistance of austempered ductile cast iron. Wear, v. 263, n. 1-6, p. 663-668, 2007.

[65] XIA, Y.; LIU, W. e XUE, Q. Friction and wear behavior of nodular cast iron modified by a laser micro-precision treatment sliding against steel under the lubrication of liquid paraffin containing various additives. Wear, v. 253, n. 7-8, p. 752-758, 2002.

[66] FENG, X. et al. Tribological properties of grey cast iron lubricated using organic compounds containing Mo and ZnDTP additives. Lubrication Science, n. February, p. 153-164, 2012.

[67] SUGISHITA, J. e FUJIYOSHI, S. THE EFFECT OF CAST IRON GRAPHITES ON FRICTION AND WEAR. Wear, v. 66, p. 209-221, 1981.

[68] SUGISHITA, J. e FUJIYOSHI, S. THE EFFECT OF CAST IRON GRAPHITES ON FRICTION AND WEAR PERFORMANCE II: VARIABLES INFLUENCING GRAPHITE FILM FORMATION. v. 68, p. 7-20, 1981.

[69] SUGISHITA, J. e FUJIYOSHI, S. The effect of cast iron graphite on friction and wear performance III: The lubricating effect of graphite under rolling-sliding contacts. Wear, v. 77, p. 181-193, 1982.

[70] PRASAD, B. K. Lubricated Sliding Wear Behavior of a Cast Iron: Effect of Graphite and/or Talc Fraction in Oil. Journal of Materials Engineering and Performance, v. 19, n. 3, p. 413-420, 2009.

[71] ATKINSON, C. .; AKBAY, T. . e REED, R. C. Theory for reaustenitisation from ferrite / cementite mixtures in Fe-C-X steels. v. 43, n. 5, p. 2013-2031, 2013. 


\section{APÊNDICE A - ESPECIFICAÇÃO DO ÓLEO PAO}

\section{ExxonMobil \\ Chemical}

\section{SpectraSyn ${ }^{\mathrm{TM}} 8$ Polyalphaolefin (PAO) Fluid}

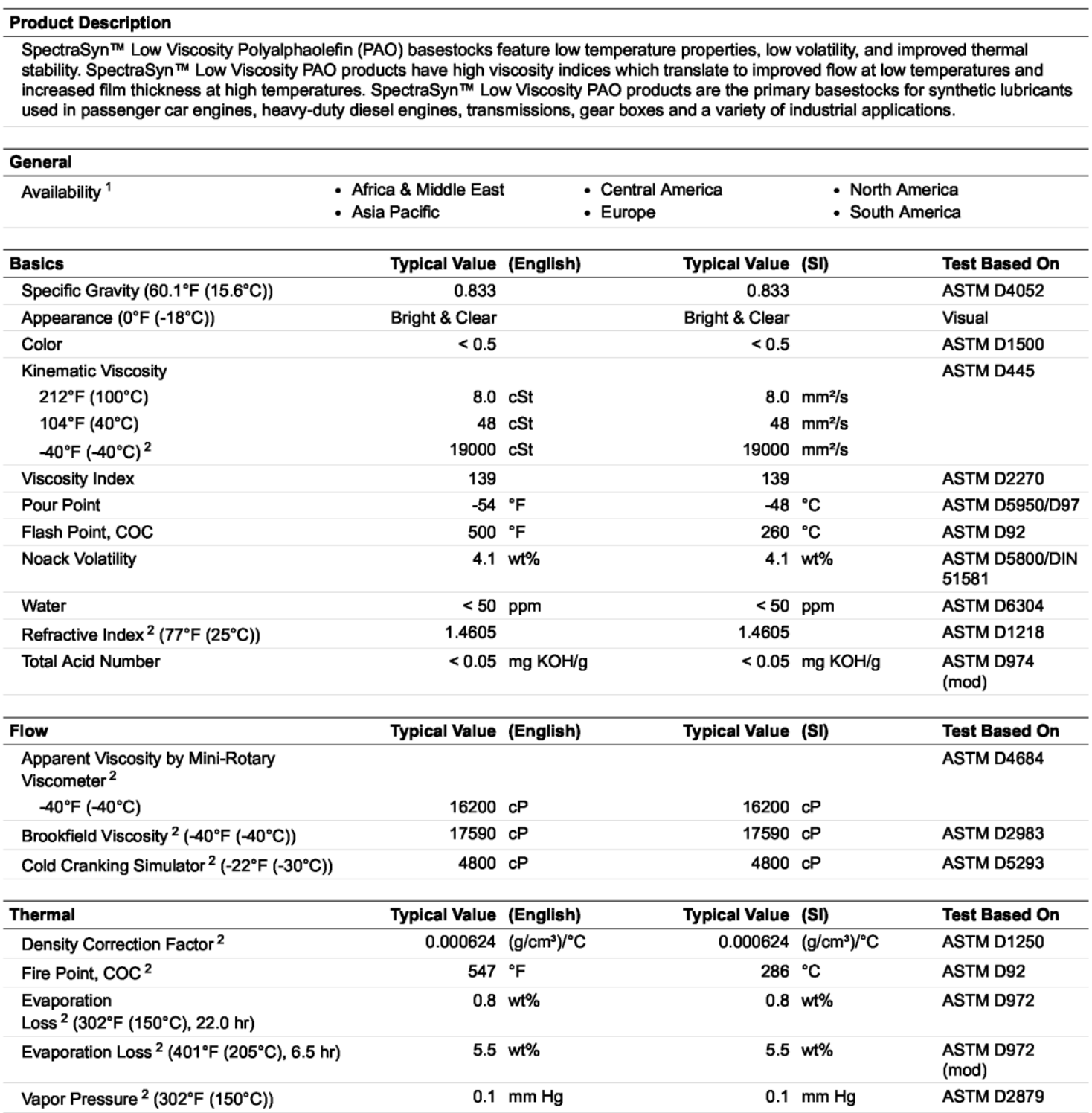

Typical properties: these are not to be construed as specifications.

(92014 ExxonMobil. ExxonMobil, the ExxonMobil logo, the interlocking "X" device and other product or service names used herein are trademarks of ExxonMobil, unless indicated otherwise. This document may not be distributed, displayed, copied or altered without ExxonMobil's prior written authorization. To the extent headers, footers, disclaimers and other information. You may not copy this document to or reproduce it in whole or in part on a website. ExxonMobil does no guarantee the typical (or other) values. Any data included herein is based upon analysis of representative samples and not the actual product shipped. The information in this document relates only to the named product or materials when not in combination with any other product or materials. We based the information on
data believed to be reliable on the date compiled, but we do not represent, warrant, or otherwise guarantee, expressly or impliedly, the merchantability, fitness for a particular purpose freedem firm patent inflied, but we do not represent, warrant, or otherwise guarantee, expressly or impliedly, the merchantability, fitness for described. The user is solely responsible for all determinations regarding any use of material or product and any process in its territories of interest. We expressly disclaim liability for any loss, damage or injury directly or indirectly suffered or incurred as a result of or related to anyone using or relying on any of the information in this document. This document is not an endorsement of any non-ExxonMobil product or process, and we expressly disclaim any contrary implication. The terms "we," "our," "ExxonMobil Chemical" and "ExxonMobil" are each used for convenience, and may include any one or more of ExxonMobil Chemical Company, Exxon Mobil Corporation, or any affiliate either directly or indirectly stewarded. 


\section{ExxonMobil Chemical SpectraSyn ${ }^{\mathrm{TM}} 8$ \\ Polyalphaolefin (PAO) Fluid}

\begin{tabular}{|c|c|c|c|}
\hline Performance & Typical Value (English) & Typical Value (SI) & Test Based On \\
\hline Dielectric Constant ${ }^{2}\left(77^{\circ} \mathrm{F}\left(25^{\circ} \mathrm{C}\right)\right)$ & 2.12 & 2.12 & ASTM D924 \\
\hline Dielectric Strength 2 & $37.7 \mathrm{kV}$ & $37.7 \mathrm{kV}$ & ASTM D877 \\
\hline High-Temp. High-Shear Viscosity ${ }^{2}$ & $2.58 \mathrm{cP}$ & $2.58 \mathrm{cP}$ & ASTM D5481 \\
\hline
\end{tabular}

\begin{tabular}{|c|c|c|c|}
\hline Solubility & Typical Value (English) & Typical Value (SI) & Test Based On \\
\hline Aniline Point ${ }^{2}$ & $267.4^{\circ} \mathrm{F}$ & $130.8^{\circ} \mathrm{C}$ & ASTM D611 \\
\hline \multicolumn{4}{|c|}{ Additional Information } \\
\hline $\begin{array}{l}\text { Technical Whit } \\
\text { National Sanite }\end{array}$ & k, category code H1, Lubric & cidental food contact & \\
\hline
\end{tabular}

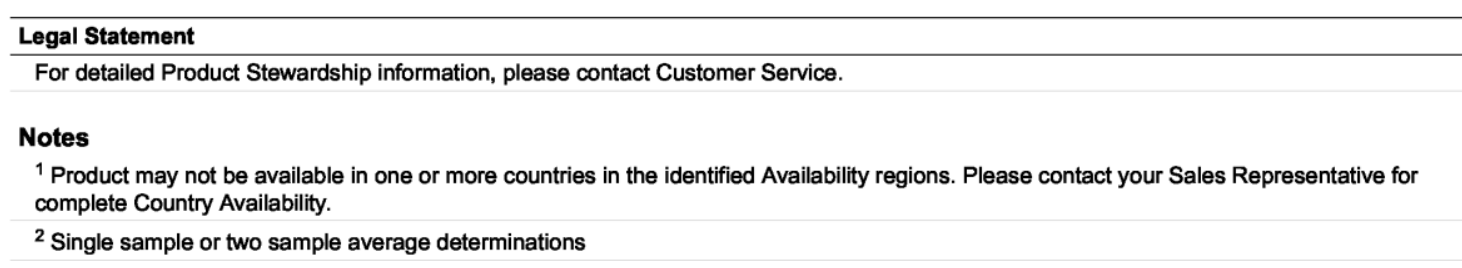

For additional technical, sales and order assistance:

Worldwide and the Americas Asia Pacific

ExxonMobil Chemical Company ExxonMobil Chemical Asia Pacific

13501 Katy Freeway 1 HarbourFront Place

Houston, TX 77079-1398 \#06-00 HarbourFront Tower One

USA

$1-281-870-6050$
Singapore 098633

$+66-2-1638699$
Europe, Middle East and Africa

ExxonMobil Chemical Europe

Hermeslaan 2

1831 Machelen, Belgium

420-239-016-274

Typical properties: these are not to be construed as specifications.

(๑)2014 ExxonMobil. ExxonMobil, the ExxonMobil logo, the interlocking " $X$ " device and other product or service names used herein are trademarks of ExxonMobil, unless indicated otherwise. This document may not be distributed, displayed, copied or altered without ExxonMobil's prior written authorization. To the extent ExxonMobil authorizes distributing, displaying and/or copying of this document, the user may do so only if the document is unaltered and complete, including all of its headers, footers, disclaimers and other information. You may not copy this document to or reproduce it in whole or in part on a website. ExxonMobil does no guarantee the typical (or other) values. Any data included herein is bes information in this document relates only to the named product or materials when not in combination with any other product or materials. We based the information on data believed to be rellable on the date complied, but we do not represent, warrant, or otherwise guarantee, expressly or impliedly, the merchantability, fitness for particular purpose, disclaim liability for any loss, damage or injury directly or indirectly suffered or incurred as a result of or related to anyone using or relying on any of the information in this document. This document is not an endorsement of any non-ExxonMobil product or process, and we expressly disclaim any contrary implication. The terms "we," "our," "ExxonMobil Chemical" and "ExxonMobil" are each used for convenience, and may include any one or more of ExxonMobil Chemical Company, Exxon Mobil Corporation, or any affiliate either directly or indirectly stewarded. 


\section{ANEXO A - DETERMINAÇÃO DA FRAÇÃO DE AUSTENITA}

O cálculo da fração de austenita na amostra temperada e temperada revenida foi feito a partir da equação:

$$
\mathrm{f}_{\gamma \mathrm{R}}=\frac{\frac{1}{\mathrm{n}_{\gamma}} \sum_{1}^{\mathrm{n}} \frac{\mathrm{I}_{\gamma}^{\mathrm{hkl}}}{\mathrm{R}_{\gamma}^{\mathrm{hkl}}}}{\frac{1}{\mathrm{n}_{\alpha}} \sum_{1}^{\mathrm{n}} \frac{\mathrm{I}_{\alpha}^{\mathrm{hkl}}}{\mathrm{R}_{\alpha}^{\mathrm{hkl}}}+\frac{1}{\mathrm{n}_{\gamma}} \sum_{1}^{\mathrm{n}} \frac{\mathrm{I}_{\gamma}^{\mathrm{hkl}}}{\mathrm{R}_{\gamma}^{\mathrm{hkl}}}+\mathrm{f}_{\theta}}
$$

Onde: $\mathrm{I}_{\alpha}^{\mathrm{hkl}}$ e $\mathrm{I}_{\gamma}^{\mathrm{hkl}}$ são as integrais dos picos das intensidades de martensita e austenita; na e $\mathrm{n} \gamma$ a quantidade de picos correspondentes as linhas hkl dos picos das integrais que foram medidas; $\mathrm{R}_{\alpha}^{\mathrm{hkl}}$ e $\mathrm{R}_{\gamma}^{\mathrm{hkl}}$ as intensidades obtidas em amostras padrões de austenita e martensita e fӨ é a fração de carbonetos.

Usando os valores das tabelas introduzindo na equação anterior. As áreas foram obtidas a partir da integração abaixo dos picos de difração usando o software Origin.

\begin{tabular}{|c|c|c|c|c|}
\hline \multicolumn{5}{|c|}{ Amostra temperada } \\
\hline medidas & HKL & Área pico Martensita (I/ $)$ & Intensidade Teórica (R) & $\mathbf{I}_{\boldsymbol{\alpha}} / \mathbf{R}$ \\
\hline 1 & 110 & 503 & 36,94 & 13,61667569 \\
\hline 2 & 200 & 153,501 & 30,52 & 5,029521625 \\
\hline 3 & 211 & 292,4 & 26,28 & 11,12633181 \\
\hline \multicolumn{2}{|c|}{ Soma } & 948,901 & & 29,77252913 \\
\hline
\end{tabular}

\begin{tabular}{|c|c|c|c|c|}
\hline \multicolumn{5}{|c|}{ Amostra temperada } \\
\hline medidas & HKL & Área pico austenita (I $\mathbf{\gamma})$ & Intensidade Teórica (R) & $\mathbf{I}_{\boldsymbol{\gamma}} / \mathbf{R}$ \\
\hline 1 & 200 & 95,421 & 69,62 & 1,370597529 \\
\hline 2 & 220 & 56,015 & 55,88 & 1,002415891 \\
\hline 3 & 311 & 80,65 & 49,17 & 1,640227781 \\
\hline \multicolumn{2}{|c|}{ Soma } & $\mathbf{2 3 2 , 0 8 6}$ & $\mathbf{4 , 0 1 3 2 4 1 2 0 2}$ \\
\hline
\end{tabular}

\begin{tabular}{|c|c|c|c|c|}
\hline \multicolumn{5}{|c|}{ Amostra temperada e revenida } \\
\hline medidas & HKL & Área pico Martensita (I $)$ & Intensidade Teórica (R) & $\mathbf{I}_{\boldsymbol{\alpha}} / \mathbf{R}$ \\
\hline 1 & 110 & 858,72 & 36,94 & 23,24634543 \\
\hline 2 & 200 & 151,74 & 30,52 & 4,971821756 \\
\hline 3 & 211 & 258,85 & 26,28 & 9,849695586 \\
\hline \multicolumn{2}{|c|}{ Soma } & $\mathbf{1 2 6 9 , 3 1}$ & & $\mathbf{3 8 , 0 6 7 8 6 2 7 7}$ \\
\hline
\end{tabular}




\begin{tabular}{|c|c|c|c|c|}
\hline \multicolumn{5}{|c|}{ Amostra temperada e revenida } \\
\hline medidas & HKL & Área pico austenita $\left(\mathbf{I}_{\mathbf{\gamma}}\right)$ & Intensidade Teórica (R) & $\mathbf{I}_{\boldsymbol{\gamma}} / \mathbf{R}$ \\
\hline 1 & 111 & 138,16 & 74,52 & 1,853998926 \\
\hline 2 & 200 & 57,8 & 69,62 & 0,830221201 \\
\hline 3 & 220 & 35,3 & 55,88 & 0,631710809 \\
\hline \multicolumn{2}{|c|}{ Soma } & $\mathbf{2 3 1 , 2 6}$ & & $\mathbf{3 , 3 1 5 9 3 0 9 3 6}$ \\
\hline
\end{tabular}

A fração de austenita retida na amostra temperada foi calculada da seguinte forma:

$$
\begin{gathered}
\mathrm{f}_{\gamma \mathrm{T}}=\frac{\frac{1}{3} * 4,013}{\frac{1}{3} * 29,772+\frac{1}{3} * 4,013} \\
\mathrm{f}_{\gamma \mathrm{T}}=0,119 \text { ou } 12 \%
\end{gathered}
$$

A fração de austenita retida na amostra temperada e revenida foi calculada da seguinte forma:

$$
\begin{gathered}
\mathrm{f}_{\gamma \mathrm{TR}}=\frac{\frac{1}{3} * 3,316}{\frac{1}{3} * 38,068+\frac{1}{3} * 3,316} \\
\mathrm{f}_{\gamma \mathrm{TR}}=0,08 \text { ou } 8 \%
\end{gathered}
$$




\section{ANEXO B - DETERMINAÇÃO DO TEOR DE CARBONO}

O teor de carbono foi estimado a partir das equações:

$$
\begin{gathered}
\mathrm{n} \lambda=2 \mathrm{dsen} \Theta \\
\frac{1}{\mathrm{~d}^{2}}=\frac{\mathrm{h}^{2}+\mathrm{k}^{2}+\mathrm{l}^{2}}{\mathrm{a}^{2}} \\
\mathrm{a}_{\gamma}=3,555+0,044 \mathrm{w}_{\mathrm{c}}^{\gamma}
\end{gathered}
$$

Os valores do ângulo teta foram obtidos no DRX para as amostras temperada e temperada e revenida. Usando a lei de Bragg, tendo os valores de teta e $\lambda(\lambda C u=1,5418 A)$ calculou-se o valor de $d$. O parâmetro de rede (a) foi determinado usando os valores de d e hkl na segunda equação. Finalmente usando os valores

\begin{tabular}{|c|c|c|c|c|c|}
\hline \multicolumn{6}{|c|}{ Amostra temperada } \\
\hline $\mathbf{h}$ & k & I & teta & $d(A)$ & $a(A)$ \\
\hline 1 & 1 & 1 & 21,793 & 2,076473724 & 3,596557991 \\
\hline 2 & 0 & 0 & 25,29 & 1,804540925 & 3,60908185 \\
\hline 2 & 2 & 0 & 37,285 & 1,272573939 & 3,599382648 \\
\hline 3 & 1 & 1 & 45,297 & 1,084609619 & 3,597243152 \\
\hline & & & & Média (a) & 3,60056641 \\
\hline & & & & desvio & 0,00580303 \\
\hline
\end{tabular}
calculados do parâmetro e rede na última equação é possível estimar o teor de

\begin{tabular}{|c|c|c|c|c|c|}
\hline \multicolumn{6}{|c|}{ Amostra temperada e revenida } \\
\hline h & k & 1 & teta & $d(A)$ & $a(A)$ \\
\hline 1 & 1 & 1 & 21,71 & 2,084026545 & 3,609639861 \\
\hline 2 & 0 & 0 & 25,275 & 1,805541422 & 3,611082843 \\
\hline 2 & 2 & 0 & 37,063 & 1,279092755 & 3,617820643 \\
\hline & & & & Média (a) & 3,612847782 \\
\hline & & & & desvio & 0,004366641 \\
\hline
\end{tabular}
carbono nas amostras. 


\section{ANEXO C - Determinação da fração volumétrica de grafita}

A determinação da fração volumétrica de grafita foi feita a partir do analisador de imagens ImageJ. A imagem a ser quantificada é aberta. Inicialmente é feito o histograma da imagem total, o acesso fica no menu Analyse histogram, como mostra a Figura 86.

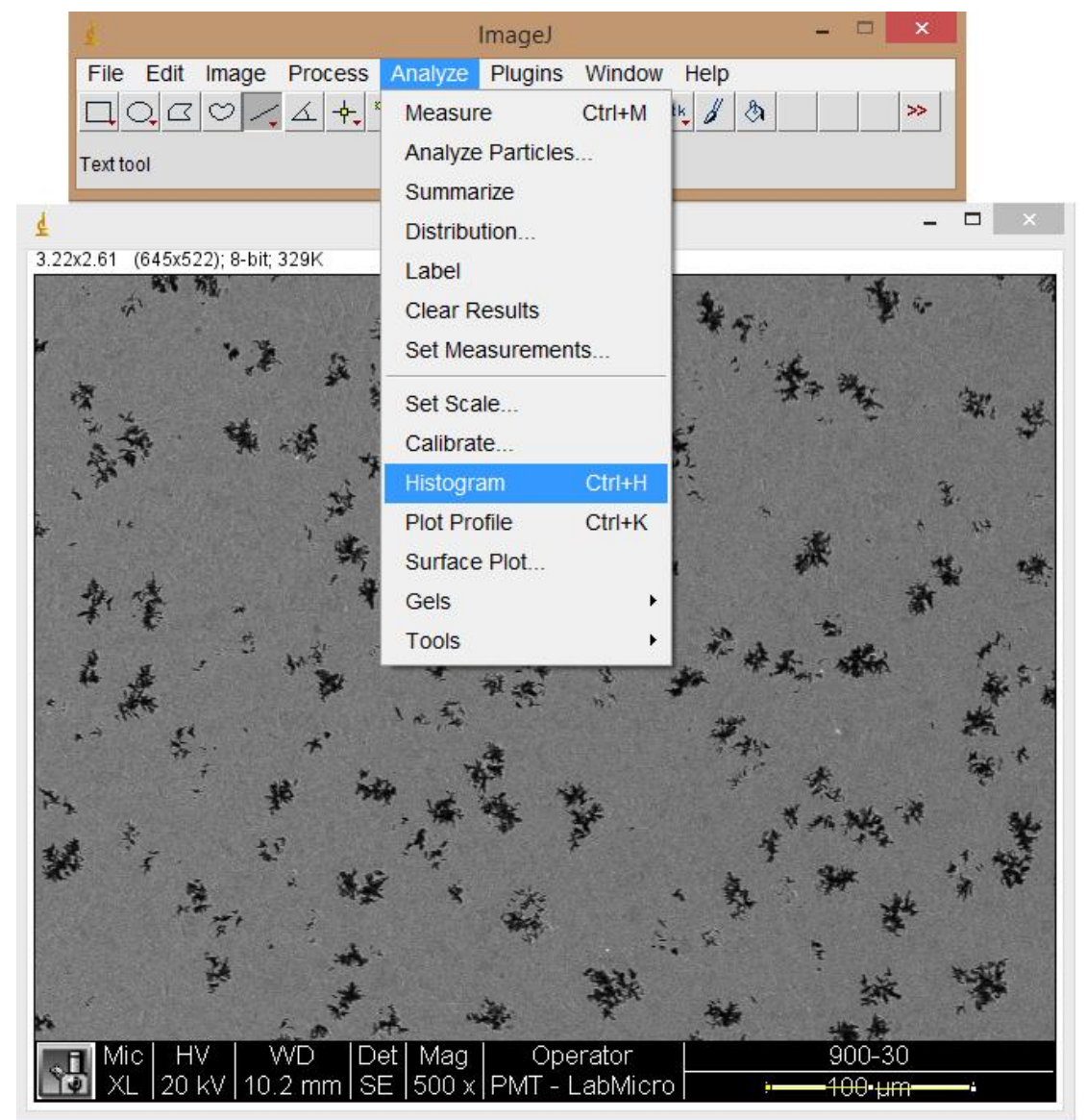

Figura 86 - Histograma da imagem analisada

O histograma é gerado (Figura 87) sendo possível geral uma lista com os pontos quantificados. A imagem a ser quantificada (grafita) é selecionada no menu image Adjust Threshold, e um novo histograma é feito das grafitas pré-selecionadas. As listas geradas são exportadas para o Origin, onde é feito a integral dos histogramas gerados. A fração volumétrica é determinada pela divisão da área de grafita sobre a área total. 


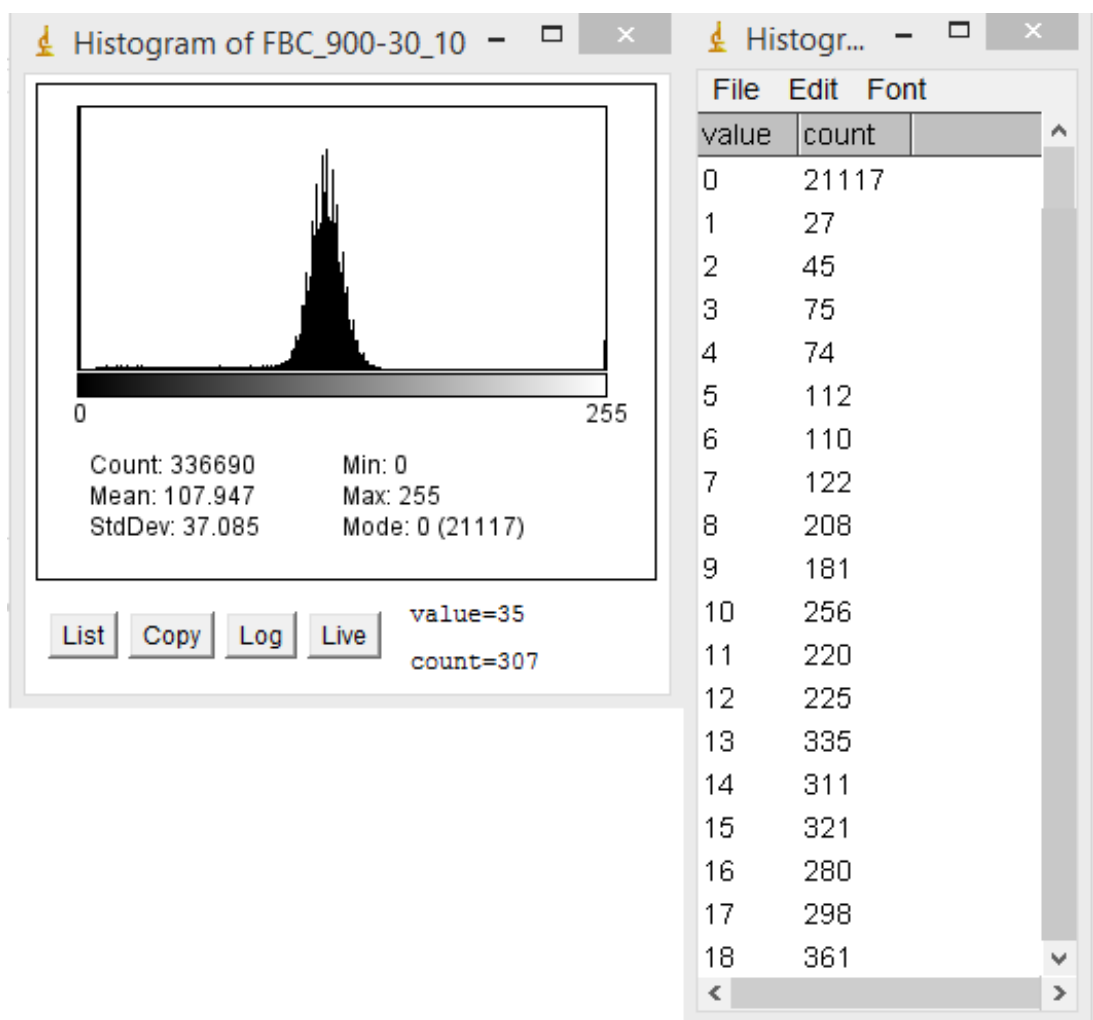

Figura 87 - Histograma e lista com dados gerados 


\section{ANEXO D - Determinação do diâmetro dos nódulos de grafita}

O diâmetro médio das partículas de grafita foi medido usando o software Image J. A micrografia a ser quantificada é aberta e um segmento de reta é desenhado sobre a escala (Figura 88); após a calibração, no menu image Adjust Threshold (Figura 89) as grafitas a serem quantificadas são selecionadas. Menu analyse - analyse particle. A faixa de área foi delimitada $\left(1-\right.$ infinito $\left.\mu \mathrm{m}^{2}\right)$ para eliminar possíveis erros de seleção no ítem anterior (Figura 90). A grafita quantificada pode ser visualizada usando o comando masks como mostra a Figura 91.

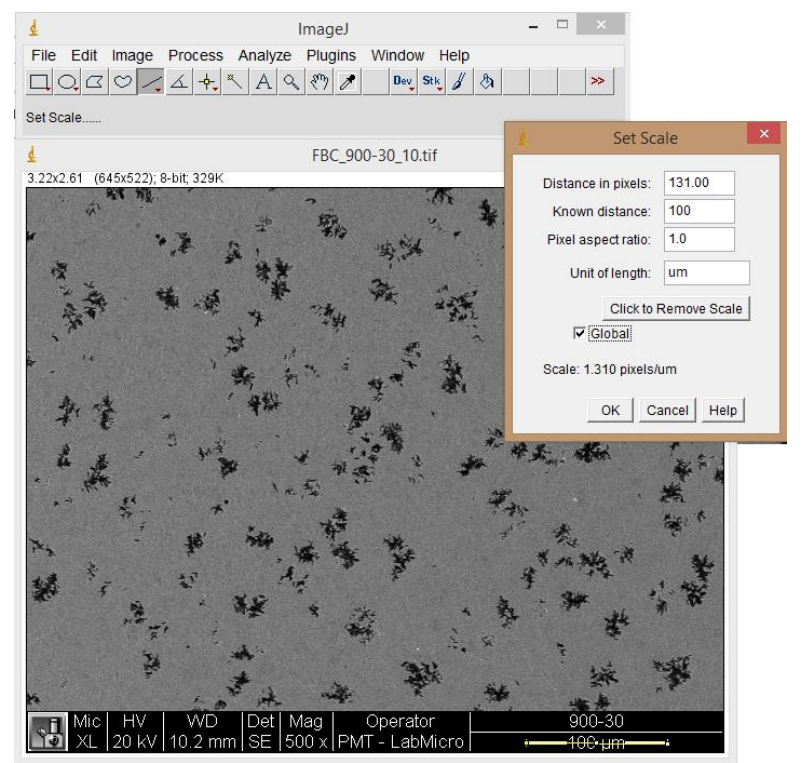

Figura 88 - calibração usando software ImageJ

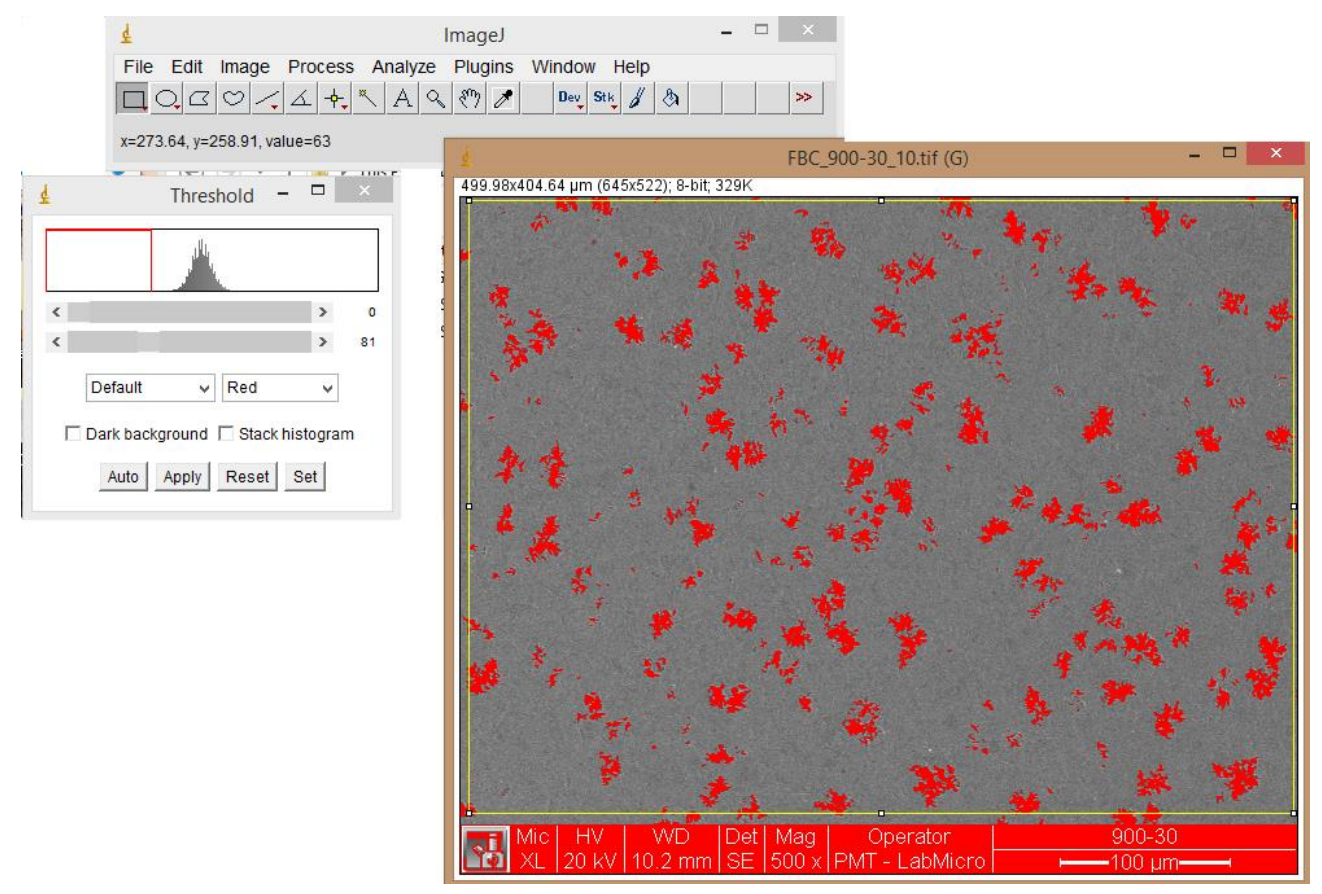

Figura 89 - Seleção das grafitas e da área a ser quantificada usando o recurso Threshold 


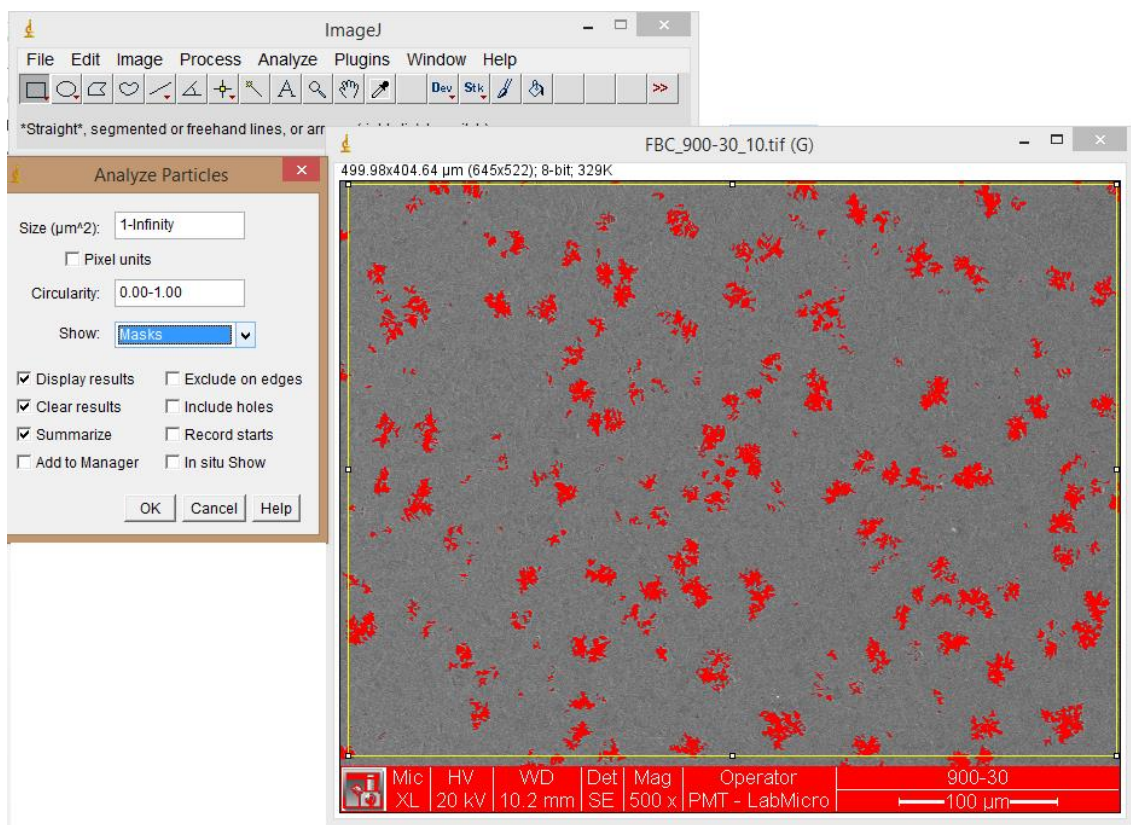

Figura 90 - quantificação das grafitas usando o comando analyse particle

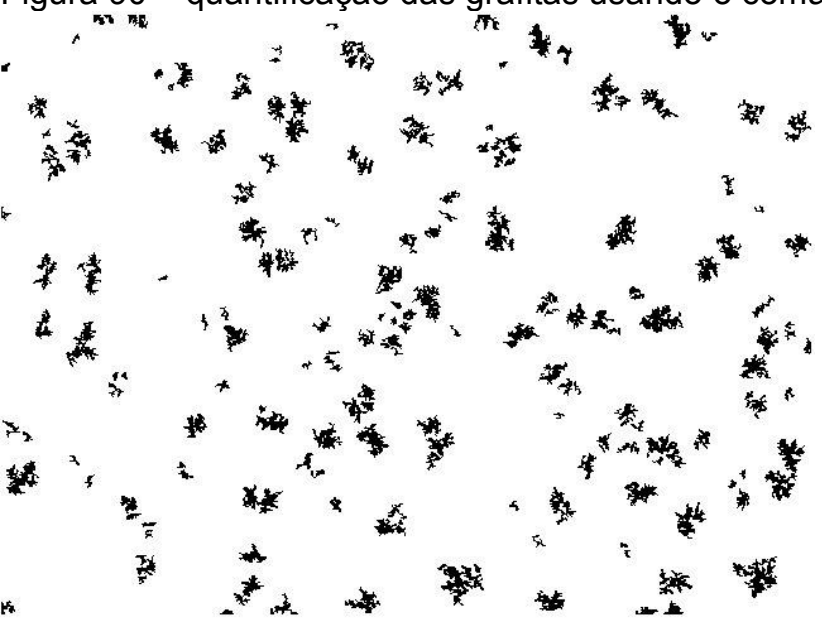

Figura 91 - máscara da grafitas quantificadas 